\author{
Universidade de São Paulo - USP \\ Faculdade de Filosofia, Letras e Ciências Humanas - FFLCH \\ Departamento de Ciência Política
}

Conrado Hübner Mendes

\title{
Direitos fundamentais, separação de poderes e deliberação
}


Universidade de São Paulo - USP

Faculdade de Filosofia, Letras e Ciências Humanas - FFLCH

Departamento de Ciência Política

\title{
Direitos fundamentais, separação de poderes e deliberação
}

Conrado Hübner Mendes

\author{
Tese apresentada ao \\ Departamento de Ciência Política \\ da Faculdade de Filosofia, Letras \\ e Ciências Humanas da Universidade \\ de São Paulo, para a obtenção do \\ título de Doutor em Ciência Política.
}

Orientador: Prof. Álvaro de Vita

São Paulo 
Ninguém tem a última palavra porque não há última palavra.

Hanna Pitkin ${ }^{1}$

1 "No one has the last word because there is no last word". ("Obligation and Consent-II", p. 52) 


\title{
Resumo
}

O controle de constitucionalidade de leis sempre foi objeto de desconfiança da teoria democrática. Sob qual justificativa juízes não eleitos podem ter a última palavra sobre o significado de direitos fundamentais? É assim que a questão costumou ser formulada pela tradição. Alguns a responderam em favor desse arranjo, outros em defesa da supremacia do parlamento. Essa seria uma encruzilhada da separação de poderes e as "teorias da última palavra" se enfrentam nesses termos. A tese investiga uma saída alternativa para esse dilema, oferecida pelas "teorias do diálogo institucional". Segundo essa corrente, a última palavra, na democracia, não existe. O trabalho defende que ambas as perspectivas, última palavra e diálogo, têm papel analítico importante a cumprir. Propõe que uma interação de caráter deliberativo, e não somente adversarial, entre os poderes, tem maiores possibilidades de, ao longo do tempo, produzir boas respostas sobre os direitos fundamentais. Torna a separação de poderes sensível ao bom argumento.

\begin{abstract}
The judicial review of legislation has always been under the distrust of democratic theory. Under what justification can unelected judges have the last word upon fundamental rights? That's the way the question has been formulated by the tradition. Some are favourable to this institutional arrangement, whereas others defend the supremacy of parliament. This would be the crossroads of the separation of powers and "theories of last word" face the dispute under these terms. The thesis investigates an alternative response to this dilemma, offered by "theories of institutional dialogue". According to it, there is no last word in a democracy. The dissertation defends that both perspectives - last word and dialogue - have an important analytical role to play. Is proposes that an interaction of a deliberative kind rather than adversarial is more likely, in the long term, to produce better answers about rights. It turns separation of powers sensitive to the quality of argument.
\end{abstract}




\section{ÍNDICE}

Capítulo 1

O mesmo velho problema

$\begin{array}{ll}\text { Capítulo } 2 & 56\end{array}$

A inclinação por juízes e cortes constitucionais

Capítulo 3

A inclinação por legisladores e parlamentos

Capítulo 4

A inclinação por ambos: diálogo sem última palavra

Capítulo 5

Auto-governo e direito ao erro

Capitulo 6

Separação de poderes e os tempos da política: diálogo ou última palavra?

Capítulo 7

Separação de poderes e legitimidade: deliberação inter-institucional 


\section{Capítulo 1 \\ O mesmo velho problema}

\section{Introdução}

Certo senso comum da teoria constitucional costuma supor, implícita ou explicitamente, que parlamentos seriam a expressão mais direta do ideal democrático, enquanto que constituições e declarações de direitos, somados à instituição do controle judicial de constitucionalidade, seriam a manifestação do constitucionalismo. ${ }^{1}$ Controvérsias sobre quem deveria ter a última palavra em conflitos sobre direitos fundamentais, dessa maneira, são percebidas como uma tensão não apenas entre duas instituições - parlamentos e cortes - mas também entre dois ideais políticos - respectivamente, democracia e constitucionalismo. Se o primeiro ideal se propõe a realizar algum tipo de governo do povo, o segundo busca assegurar que o poder tenha limites. ${ }^{2}{ }^{3}$ Por trás da interação entre duas instituições políticas, portanto, encontra-se o problema de como balancear as demandas procedimentais e substantivas desses dois ideais. ${ }^{4}$

Várias dificuldades conceituais, morais e institucionais decorrem desses slogans abstratos, particularmente se o mesmo sistema político persegue a combinação dos dois ideais como fundamento de sua legitimidade e da cobrança de obediência. Essa combinação foi a escolha da maioria dos regimes políticos ocidentais durante o séc. XX, e a expressão "democracia constitucional" o nome convencionado para se referir a eles. Apesar das diferenças, esses regimes compartilham alguns

\footnotetext{
${ }^{1}$ Abordei essa associação entre, de um lado, democracia e parlamento, e, de outro, constitucionalismo e corte constitucional, no cap. 1 de minha dissertação de mestrado. Controle de Constitucionalidade e Democracia, p. 10.

${ }^{2}$ Frank Michelman resume melhor essa tensão: “'Democracy' appears to mean something like this: popular political self-government - the people of a country deciding for themselves the content (...) of the laws that organize and regulate their political association. 'Constitutionalism' appears to mean something like this: the containment of popular political decision-making by a basic law, the Constitution - 'a law of lawmaking', we shall sometimes call it - designed to control which further laws can be made, by whom, and by what procedures" (Brennan and Democracy, p. 5).

${ }^{3} \mathrm{Cf}$. os argumentos de Dworkin sobre a interdependência, ao invés de tensão, entre esses dois ideais e também a tese sobre a "unidade do valor" e a inseparabilidade entre os conceitos políticos. Freedom's Law, "Introduction"; "Hart's Postcript and the Character of Political Philosophy"; Justice for Hedgehogs.

${ }^{4}$ Os problemas oriundos de se conceber demandas procedimentais e substantivas, tanto da democracia quanto do constitucionalismo, serão melhor abordados no tópico 5 , onde tento sistematizar alguns dos principais níveis teóricos em que essa discussão da teoria política geralmente ocorre.
} 
denominadores comuns do ponto de vista institucional. Para os propósitos desse trabalho, é suficiente observar que quase todos possuem uma constituição escrita, um poder legislativo representativo e uma corte constitucional que exerce o controle de constitucionalidade. ${ }^{5}$

Uma explicação hegemônica da divisão de trabalho entre essas duas instituições é dada por Ronald Dworkin, que enxerga a defesa de direitos fundamentais como a tarefa central das cortes - o "fórum do princípio" - e a deliberação sobre políticas públicas (policies) o papel principal de parlamentos representativos - que poderíamos chamar de "fórum da utilidade". Para ele, a objeção democrática contra a legitimidade da revisão judicial confunde o que a democracia efetivamente significa. De acordo com sua concepção constitucional de democracia, ${ }^{6}$ esse regime tem alguns requisitos morais substantivos que não são atendidos necessariamente por um procedimento majoritário, mas pela "resposta certa" sobre direitos fundamentais. ${ }^{7} \mathrm{O}$ procedimento decisório, nesse caso, pouco importa para a legitimidade da decisão. Tal "resposta certa" sobre direitos fundamentais é inspirada pelo ideal da "igual consideração e respeito", e ajuda a promover a "filiação moral" de cada pessoa à comunidade política. Sem essa filiação moral prévia, procedimentos majoritários (ou quaisquer outros) não teriam absolutamente nenhum valor e não satisfariam um padrão minimamente desejável de igualdade. $^{8}$ Em resumo, democracia, quando estão em jogo direitos fundamentais, é uma questão de output substantivo, não de input procedimental. ${ }^{9}$

\footnotetext{
5 Obviamente, esse retrato simplifica as variações institucionais encontradas nas democracias contemporâneas. Tais variações passam de modelos fortes de revisão judicial (o modelo difuso norteamericano e o modelo concentrado germânico são os dois "tipos puros" encontrados na literatura comparada) para modelos fracos de revisão judicial (encontrados em inovações recentes dentro do "constitucionalismo do commonwealth", especialmente no Canadá, Nova Zelândia e Reino Unido), ou mesmo para modelos não judiciais, como o francês. As preocupações teóricas apontadas aqui, contudo, são mais abrangentes e não precisam se restringir a um único arranjo institucional. Esse capítulo abordará mais adiante o "isolamento das variáveis institucionais". Cf. Stephen Gardbaum, “The New Commonwealth Model of Constitutionalism".

${ }^{6}$ Dworkin, em mais uma confirmação de sua versatilidade terminológica para um mesmo conceito, também chamou sua concepção de democracia de "communal conception " ou "partnership conception" em outras oportunidades.

${ }^{7}$ Para Waldron, Dworkin também comete o erro de inferir um arranjo institucional a partir de uma consideração substantiva, o que confundiria as duas tarefas principais da filosofia política. Um procedimento decisório, de acordo com ele, não pode ser justificado em termos de substância (v. "Freeman's Defense of Judicial Review").

${ }^{8}$ Trata-se da distinção que, em outro texto, Dworkin faz entre "legitimate majority rule" e "mere majoritarianism". (“Constitutionalism and Democracy", p. 1)

${ }^{9}$ Dworkin desenvolve diferentes partes desse argumento amplo em diferentes lugares. Suas principais referências no assunto são Freedom's Law, "Introduction", Sovereign Virtue, capítulos 1 e 2, "Equality, democracy and Constitution: we the people in court", e "The Partnership Conception of Democracy".
} 
A maioria das democracias constitucionais contemporâneas apresenta, como filosofia política de base, alguma versão dessa explicação dworkiniana. Independentemente de variações no detalhe, a prática da revisão judicial é freqüentemente associada a promessas mais ou menos ambiciosas de proteção de direitos e das minorias. ${ }^{10}$ Pretendo testar essa justificativa tradicional à luz de recentes críticas e outros tipos de defesa da revisão judicial.

Nesse longo capítulo de abertura, resumo o argumento desenvolvido em minha dissertação de mestrado, mostro os alvos atacados, os passos conquistados e os problemas ainda não resolvidos (tópico 2). Naquela oportunidade, esbocei um modelo de revisão judicial como contra-poder e operador de veto, não como "reserva de justiça" da democracia. No terceiro tópico, explico o percurso argumentativo desta tese, em estrita continuidade com a dissertação, e a sua estrutura de capítulos. No quarto tópico, faço algumas digressões metodológicas que clareiam questões subjacentes à tese. Finalmente, articulo uma estrutura analítica para teorizar sobre a separação de poderes. A intenção é ilustrar como as discussões sobre o papel da revisão judicial na democracia não podem ignorar a pergunta complexa que a teoria da separação de poderes deve enfrentar: quem decide o que e como e quando e por que numa democracia? ${ }^{11}$ Diferentes abordagens da revisão judicial dão respostas alternativas a essa questão, mesmo quando não assim estruturadas ou não apresentem explicitamente respostas a todos os seus elementos. Mostro, nesse mesmo tópico, os níveis de análise em que os desacordos dessas teorias ocorrem e como tal pergunta ajuda a suscitar o problema de maneira mais produtiva. Encerro o capítulo com um preâmbulo dos três capítulos seguintes.

\section{Controle de constitucionalidade: reserva de justiça ou contrapoder?}

\footnotetext{
${ }^{10}$ Há também outras justiticativas para a revisão judicial, como a supremacia da constituição, o estado de direito e o federalismo. Não serão, porém objeto desse trabalho, exceto incidentalmente.

11 Omito a dimensão de "onde" para evitar outras discussões intrincadas sobre espaço politico, soberania estatal, instituições internacionais etc., que não se aplicam a essa tese.
} 
Álvaro de Vita, em prefácio ao livro derivado de minha dissertação de mestrado, ${ }^{12}$ resume o argumento lá presente: "Se recusamos a justificação mais ambiciosa para o instituto do controle de constitucionalidade - a de que o tribunal, por ser o 'fórum do princípio', estaria mais apto do que a legislatura para garantir direitos e liberdades fundamentais protegidos constitucionalmente -, haveria alguma outra forma de justificá-lo? Possivelmente, sim. Mas uma justificação menos ambiciosa provavelmente também leva a um entendimento mais circunspecto e prudente da autoridade de realizar o controle jurisdicional de constitucionalidade. Apesar de o argumento de teor negativo ser o forte deste livro, há também algumas pistas (que, quem sabe, poderiam ser objeto de reflexão mais forte do autor em outro trabalho) para pensar o problema nessa direção". ${ }^{13}$

Nesse resumo, procurarei descrever o ponto de chegada da pesquisa de mestrado que, de alguma maneira, é o ponto de partida para essa tese. As "pistas" a respeito de argumentos positivos sobre o papel da revisão judicial lá presentes serão objeto de desenvolvimento mais cuidadoso. Aquele texto promoveu algumas realizações importantes: afastou justificativas apressadas do controle de constitucionalidade, as quais, em geral, tendem a dar um "cheque em branco" ao tribunal e a lhes conferir uma credencial especial; relativizou duas inferências consolidadas e pouco tematizadas na literatura constitucional brasileira: (i) se democracia não é só vontade da maioria, uma instituição anti-majoritária é desejável e necessária, ${ }^{14}$ e (ii) se a constituição é suprema e deve ser obedecida inclusive pelo legislador, deve existir um agente controlador externo que fiscalize tal obediência; ${ }^{15}$ reafirmou a incerteza e a falibilidade da política em face das promessas arriscadas da teoria constitucional em nome da efetivação de direitos; ${ }^{16}$ reduziu expectativas em

\footnotetext{
${ }^{12}$ Controle de Constitucionalidade e Democracia, dissertação de mestrado defendida em janeiro de 2004.

${ }^{13}$ Controle de Constitucionalidade e Democracia, p. XXI.

${ }^{14}$ Esta inferência decorreria do vício de se derivar um determinado conteúdo a partir de uma certa forma, um resultado a partir de certo procedimento decisório. Defendi que a reserva de justiça não depende do controle de constitucionalidade e que isso corresponderia a confundir, nos termos de Waldron, teoria da justiça com teoria da autoridade.

${ }^{15}$ Veremos novamente essa discussão nos capítulos 2 e 3 da tese, e como Carlos Santiago Nino trata do tema (The constitution of deliberative democracy, p. 189-196).

${ }^{16}$ Dilemas constitucionais, como todo dilema moral, nem sempre terminam ou mesmo permitem "finais felizes" (expressão famosa de Dworkin, que disse ser o objetivo da interpretação jurídica terminar em "happy endings"). Freqüentemente, envolvem "tragédias", soluções "não ótimas", às vezes encobertas por trás da cortina de fumaça de uma retórica constitucional contemporizadora. Isso não é produto apenas de eventual "erro judicial", mas da essência mesma da interpretação constitucional. Três referências interessantes a respeito são: Rebecca Brown, "Constitutional Tragedies: the dark side
} 
relação ao tribunal constitucional, que não tem como carregar o ônus de nos proteger contra as intempéries da política, ${ }^{17}$ apresentou, ainda de forma embrionária, um papel a ser desempenhado pela revisão judicial: a corte como um contrapeso à política majoritária e, mais do que isso, como instituição com a oportunidade de inserir um argumento moral na agenda, que chamei de processo de interlocução institucional. As idéias de "desaceleração da política majoritária" e de "interlocução institucional" são as "pistas" que essa tese procurará dissecar.

A dissertação formulou um argumento negativo contra uma forma tradicional de se pensar a revisão judicial. Não somou a isso um argumento positivo em favor do legislador, dedução equivocada que eventualmente se faz em face de objeções contra a revisão judicial. Criticar a revisão não equivale, portanto, a defender necessariamente o legislador representativo. Ataquei uma certa justificativa, não a existência do controle. Não se trata de exercício trivial, pois a forma de justificar determina como entendemos o papel dessa instituição, como depositamos expectativas sobre o seu desempenho e como efetivamente ela opera essa função.

Sustentei que essa forma convencional de olhar para o controle de constitucionalidade superestima seu papel e sua responsabilidade, ao mesmo tempo que atrofia o dos outros poderes. A constituição, assim, passa a ter um único centro de gravidade, um único guardião. Os outros atores políticos vão testando impunemente os seus limites. Nenhuma condenação moral recai sobre eles porque, afinal, não têm a responsabilidade de promover os valores constitucionais, mas apenas de tomar decisões políticas ordinárias. Deferem, comodamente, o escrutínio constitucional ao tribunal e abdicam da tarefa de formular um argumento constitucional consistente e sincero.

of judgment", em Levinson, Sanford e Eskridge, William (eds.), Constitutional Stupidities and Constitutional Tragedies, p. 39; James E. Fleming, Securing Constitutional Democracy (em especial o cap. 10, "Constitutional Imperfections and the Pursuit of Happy Endings: Perfecting our Imperfect Constitutions", p. 210); Lorenzo Zucca, Constitutional Dilemmas.

${ }^{17}$ Louis Fisher, em referência à decisão do caso Dred Scott, que culminou na Guerra Civil Americana, afirmou: "The belief in judicial supremacy imposes a burden that a Court cannot carry. It sets up expectations that invite disappointment if not disaster". Em outra passagem, enfatizou a mesma idéia: "The habit of looking automatically to the courts to protect constitutional liberties is ill-advised" (Constitutional Dialogues, p. xx). 
Claro que dificilmente alguém verbaliza isso. Nenhum livro de direito constitucional diz que os poderes têm carta branca para violar a constituição e que podemos nos tranqüilizar pois, em última instância, o tribunal recomporá a ordem político-constitucional. Eventualmente, chegam até a mencionar o papel dos outros poderes. Na prática, porém, as implicações de certas ênfases no papel messiânico do tribunal continuam a produzir uma cultura jurídica centrada nas cortes judiciais e excessivamente apegada ao "guardião da constituição", o que acaba por empobrecer a experiência democrática.

Muitas das conclusões da dissertação são meras aplicações, àquela questão específica, de certas máximas da sabedoria política: não há procedimento que garanta resultados justos; não há instituição infalível, por melhor que seja desenhada; de uma determinada concepção de justiça substantiva não advém um desenho institucional. Opor-se a certas justificativas da revisão judicial não significa abdicar do debate substantivo. Em outras palavras, atacar seu lastro teórico convencional não implica curvar-se a qualquer decisão majoritária, ou a ser obrigado a permanecer em silêncio quanto à justiça das decisões legislativas - "quem" e "como" decide é uma questão diferente de "o que" decide. Saber quem deve decidir, portanto, não é questão de hermenêutica constitucional, mas de desenho institucional - boas técnicas de interpretação constitucional não resolvem qualquer objeção democrática a qualquer instituição, não indicam quem deve decidir. ${ }^{18}$

Argumentei que uma descrição fantasiosa da missão do controle de constitucionalidade se acomoda a uma postura complacente que não interpela a legitimidade do STF quando este declara a inconstitucionalidade de uma lei ou emenda constitucional.

Uma crítica suscitada contra meu argumento cogitou que ele promoveria uma defesa ingênua e purista da democracia representativa por desconsiderar um importante fórum de oposição democrática e por, supostamente, fazer vistas grossas ao papel fundamental que o judiciário tem cumprido no período de redemocratização. "Purista" e "ingênua", ou mesmo "idealista" e "utópica" são adjetivos por meio dos quais se costuma criticar a teoria política normativa, sem compreender o seu papel de ${ }^{18}$ Controle de Constitucionalidade e Democracia, p. 12-13. 
fixar valores e parâmetros que auxiliam no julgamento e na reforma das instituições reais. Por trás dessa crítica, também pode haver uma ingenuidade ainda mais alarmante: supõe que o tribunal pode fazer o que as instituições representativas não têm feito. Por fim, essa crítica revela também uma incompreensão: apresentar uma objeção aos modos de justificar o controle de constitucionalidade não tem nenhuma relação com uma crítica geral ao papel do judiciário na democracia, e tampouco idealiza o legislador representativo.

Minha dissertação tratou do tema pela lente de dois autores contemporâneos que protagonizam este debate, Ronald Dworkin e Jeremy Waldron, e tentou transpor esta matriz de análise para o regime constitucional brasileiro.

Para Dworkin, a democracia, na sua versão mais genuína e desejável, não é apenas um regime em que indivíduos se juntam para tomar decisões coletivas, processar seus interesses individuais e convertê-los em política pública por intermédio da regra de maioria. Democracia é também isso, mas, antes, precisa conquistar a filiação moral de seus membros na comunidade política. Portanto, para que todos possam se juntar, agregar seus interesses e conferir qual será o produto final, é preciso que se sintam pertencentes a essa comunidade. Este laço moral se forma somente por meio de requisitos substantivos, traduzidos pela síntese da "igual consideração e respeito".

Democracia, assim, para que mereça o lugar de epítome da justiça política, não pode se restringir à satisfação do bem-estar geral (questões de policy), mas deve respeitar direitos individuais (questões de princípio). As decisões sobre a primeira dimensão se legitimam pelo critério de "quem" e "como" decide: um parlamento representativo por meio do método puramente estatístico da regra de maioria, que promove a igualdade de impacto - "um homem, um voto" (legitimação ex ante). As decisões sobre a segunda, no entanto, legitimam-se apenas por seu conteúdo, pela resposta certa, independentemente de quem decida (legitimação ex post). Se ao tribunal couber essa missão, não há que se questionar sua falta de legitimidade por não ter sido eleito, pois esta não seria a forma de mensurar a legitimidade do "fórum do princípio". 
Jeremy Waldron rejeita esta justificativa. Ela desprezaria, afinal, o desacordo moral reinante numa sociedade pluralista, circunstância fundamental da política contemporânea. Atribuir a juízes a decisão sobre questões moralmente controversas, retirando dos cidadãos a possibilidade de emitir seu juízo moral num procedimento majoritário, desrespeitaria o que a democracia teria de mais valioso: a inexistência de hierarquia entre os cidadãos, que decidem em igualdade de condições seus problemas coletivos. Como não há acordo possível sobre conteúdo, há que se fazer um acordo procedimental para decidir tal conteúdo: sua proposta é a maximização do direito de participação, o direito dos direitos, que permite a todos se realizarem igualitariamente como sujeitos autônomos em votação pública.

Segundo ele, quando a teoria política se propõe a construir um arranjo institucional, a pergunta decisiva a se fazer é "quem deve decidir?", jamais "o que decidir?”. Dado que as instituições são falíveis e que sempre haverá desacordo sobre a correção ou a verdade de suas decisões, a promessa substantivista de que dada instituição é legítima porque respeita direitos não pode ser cumprida. O dever de obediência às suas decisões não pode depender do seu acerto. ${ }^{19} \mathrm{~A}$ revisão judicial, neste sentido, deve ser descrita de forma mais realista e sincera, na perspectiva exclusivamente procedimental: quando legislador e corte discordam, a vontade da última prevalece. É a isso, e a nada mais, que corresponde este arranjo institucional. Vista dessa perspectiva, a revisão judicial perde o lastro simbólico sedutor que tradicionalmente vem a reboque de sua descrição: a promessa de proteção dos direitos fundamentais.

Isso não significa, para Waldron, que a teoria política não possa enfrentar o problema da justiça. Este estaria, todavia, em outro plano cognitivo, diferente do institucional, que somente pode ser definido em termos formais, por meio da indicação de "quem decide". Saber o que é o conteúdo da democracia continuaria na pauta da teoria política, como fonte de argumentação e convencimento, mas não

\footnotetext{
${ }^{19}$ Essa discussão aparece em profusão, obviamente, na teoria do direito. Neil MacCormick, por exemplo, traduz esse mesmo problema por meio da distinção entre a "validade" da decisão judicial (e, portanto, o dever de obedecê-la), de sua "correção". A possibilidade de conceber um juiz "falível" depende da possibilidade de julgar a correção de sua decisão independentemente de sua validade (Cf. Rhetoric and the Rule of Law, cap. 13).
} 
poderia interferir no desenho das instituições democráticas. O erro da teoria constitucional teria sido misturar os dois planos.

Comparei os argumentos de Dworkin e Waldron por dois ângulos. Pelo prisma da igualdade política, ${ }^{20}$ Waldron aponta para a conquista moral que a regra da maioria representa. Dworkin, por sua vez, busca uma versão mais genuína de igualdade, que não se limite à noção modesta por trás do voto majoritário - a igualdade de consideração e respeito. Em segundo lugar, indiquei como ambos se posicionam em relação à epistemologia moral e suas implicações. Para Waldron, a eventual existência de resposta certa para os dilemas morais é irrelevante para os fins de se pensar em instituições, uma vez que o desacordo moral em sociedades pluralistas resiste aos melhores argumentos. Do desacordo inexorável, resta apenas adotar um procedimento que dê a cada indivíduo o mesmo valor. Para Dworkin, mesmo que não seja possível demonstrar a resposta certa e que cortes possam errar, estas estariam melhor posicionadas e teriam uma expertise para encontrar tal resposta.

Argumentei, aderindo a uma parcela dos argumentos de Waldron, que a defesa da revisão judicial naqueles termos dependeria de uma presunção da infalibilidade judicial e do egoísmo legislativo (ou ao menos da "menor falibilidade judicial"). ${ }^{21}$ Considerando, conforme propõe o próprio Dworkin, que a interpretação das cláusulas abstratas da constituição é ato criativo de manifestação de convicções morais, e não um juízo técnico de derivação lógica, torna-se ainda menos plausível aquele tipo de construção teórica. Com base num sofisma ("da supremacia da constituição decorre o controle de constitucionalidade"), nasceu uma larga corrente do direito constitucional que esfumaçou o papel que essa instituição pode efetivamente cumprir numa democracia. Esta descrição edulcorada da democracia não cumpre o dever teórico e empírico de analisar se tribunais constitucionais reais efetivamente realizam as promessas do constitucionalismo. Satisfaz-se com uma legitimação ex ante e abstrata.

Entretanto, se não pode haver resposta teórico-normativa para questão empírico-descritiva, e se "respeitar direitos", condição de legitimidade da revisão judicial nesta corrente, é questão empírica (substantiva, não meramente

\footnotetext{
${ }^{20}$ Controle de Constitucionalidade e Democracia, p. 115.

${ }^{21}$ Controle de Constitucionalidade e Democracia, p. 121.
} 
procedimental), a teoria constitucional tem o ônus de demonstrar que o judiciário "respeita direitos". ${ }^{22}$ Mesmo que perseguisse este propósito e lançasse mão de análises de jurisprudência para avaliar a correção das decisões, como o fez Dworkin, esta busca seria pouco frutífera para justificar a revisão judicial, uma vez que o respeito a direitos não se prova de maneira incontroversa. ${ }^{23}$ Além disso, para fins das escolhas de desenho institucional, um exame do mérito comparativo de parlamentos e cortes não poderia ser caso a caso.

A dissertação lançou mão de outro fundamento para justificar a revisão judicial. Olhando para a constituição como máquina procedimental que dilui as funções da soberania para que elas se controlem mutuamente, e não para que tenham missões substantivas, a revisão judicial pode receber explicação mais convincente. Se a separação de poderes é uma cadeia decisória que distribui faculdades de vetar e de estatuir, caberia ao judiciário, quando dotado de um bom argumento, vetar decisões legislativas com a finalidade de qualificar a interlocução institucional com argumentos moralmente densos.

Esse veto se justifica não pelo seu conteúdo, que será necessariamente controverso, mas pela razão prudencial de acautelar o sistema político contra sobressaltos majoritários. O que ele faz, portanto, não é assegurar o mínimo ético do regime democrático, mas retardar o processo decisório, esperando que o tempo possa contribuir para uma decisão de maior densidade deliberativa. Portanto, dentre os vários tipos de fundamentos existentes para a revisão judicial, cada um deles com implicações práticas distintas, a dissertação opta por aquele que desidealiza o papel deste arranjo, eximindo-o da responsabilidade de salvar a democracia dos perigos da política. Trata a corte "com a mesma desconfiança" tradicionalmente dispensada ao legislador, e confere as implicações teóricas dessa atitude. ${ }^{24}$

No lugar de justificar a revisão judicial com base na necessidade de proteção de direitos fundamentais, sustentei que a separação de poderes e seu potencial para a

\footnotetext{
${ }^{22}$ Controle de Constitucionalidade e Democracia, p. 27 e 127-128.

${ }^{23}$ A natureza da argumentação jurídica, conforme Neil MacCormick, é persuasiva, não demonstrativa. (Cf. Rhetoric and the Rule of Law, p. 2)

${ }^{24}$ Controle de Constitucionalidade e Democracia, p. 133.
} 
limitação da autoridade política propiciam uma base mais sólida para este arranjo. ${ }^{25}$ Em vez de uma razão messiânica, temos uma razão prudencial. Mais do que isso, propus uma razão prudencial ambiciosa: "um veto qualificado pela linguagem dos direitos". ${ }^{26}$ Essa é a principal "pista" da dissertação que tentarei decifrar nessa tese. A revisão judicial, além de um mero contrapeso ou "um veto a mais", legitima-se por seu potencial de enriquecer a qualidade argumentativa da democracia, por propiciar uma "interlocução institucional". ${ }^{27}{ }^{28}$

No sistema constitucional brasileiro promulgado em 1988, uma adesão unânime à justificativa idealista do controle de constitucionalidade conduziu-o ao paroxismo. A escolha da revisão judicial, contudo, não pode vir no mesmo pacote da validade moral das cláusulas pétreas. ${ }^{29}$ Em virtude da existência dessas cláusulas, não só o legislador ordinário, mas também o reformador constitucional estão sujeitos à revisão judicial, que é exercida em dois níveis (contra leis ordinárias e contra emendas constitucionais). ${ }^{30}$ Assim, desenha-se um sistema no qual o circuito decisório termina na instituição desprovida do lastro representativo, dotada de capacidade de vetar, não a de estatuir. ${ }^{31}$ Para suplantar uma decisão do STF que discorde do reformador constitucional, somente uma ruptura ou uma convocação constituinte.

A dissertação, ao rejeitar a premissa substantivista em geral invocada para defender tal enrijecimento do processo decisório, tenta mostrar que a revisão judicial de emendas constitucionais carece de justificativa mais convincente. Se as instituições são falíveis, e se os casos de interpretação de direitos fundamentais são controversos,

${ }^{25}$ Para localizar essas diferenças na tradição da teoria constitucional, poderíamos dizer que a fundamentação da revisão judicial com base na separação de poderes corresponde à perspectiva madisoniana, enquanto que aquela com base em direitos fundamentais, à perspectiva dworkiniana (alguns diriam lockeana, mas, conforme demonstrado por Waldron, Locke defendeu restrições substantivas ao poder político baseadas em direitos, jamais um controle institucional sobre o legislador).

${ }^{26}$ Controle de Constitucionalidade e Democracia, p. 133.

${ }^{27}$ Controle de Constitucionalidade e Democracia, p. 132. A idéia de "interlocução" e "interlocutor" institucional também aparece em outras partes do livro. Cf. p. 23, 166, 171.

${ }^{28}$ Esses dois componentes da defesa positiva da revisão judicial ([i] contrapoder / veto e [ii] articulação de uma nova linguagem à interlocução institucional) serão desenvolvidos, respectivamente, nos capítulos 6 e 7 dessa tese.

${ }^{29}$ Controle de Constitucionalidade e Democracia, p. 166 e 169.

${ }^{30}$ Controle de Constitucionalidade e Democracia, p. 166.

${ }^{31}$ É hoje pouco plausível afirmar que o controle de constitucionalidade se limita a "vetar" e não a "estatuir", ou, em outros termos, a ser apenas um legislador negativo, não positivo. Há diferentes formas de exercer essa faculdade criativa. Uma mais atual refere-se aos métodos interpretativos que aceitam a constitucionalidade de leis desde que interpretadas em sentidos específicos. Essa característica apenas reforça o caráter problemático deste arranjo, em particular no desenho brasileiro. 
caberia indagar qual delas deveria ter o "direito de errar por último". O erro da instituição majoritária pode insuflar maior responsabilidade coletiva do que o erro de uma instituição não representativa, e a oportunidade de errar é inerente ao autogoverno democrático. Assim, ao aplicar o argumento geral ao desenho constitucional brasileiro, sustento duas proposições negativas: as razões conhecidas (proteção de direitos) não são aceitáveis; as razões residuais (contrapeso institucional) não podem levar tão longe. ${ }^{32}$

Robert Dahl, em passagem na qual equipara o papel do tribunal ao regime de "quase guardiões" (quasi-guardianship), indica preocupação parecida. A aposta nesse tipo de arranjo institucional precisa lidar, no plano empírico, com ônus da prova argumentativa, isto é, até que se demonstre a existência de certas circunstâncias excepcionadoras (a "tirania da maioria", p. ex.), presume-se que o legislador eleito é a autoridade legítima para dirigir as escolhas morais da democracia: ${ }^{33}$

"A heavy burden of proof should therefore be required before the democratic process is displaced by quasi guardianship. It should be necessary to demonstrate that the democratic process fails to give equal consideration to the interests of some who are subjects to its laws; that the quasi-guardians would do so; and that the injury inflicted on the right to equal consideration outweighs the injury done to the right of a people to govern itself". ${ }^{34}$

O autor reconhece a dificuldade de se provar cada uma dessas pré-condições e a importância de se dar ao povo oportunidade de errar e de acertar. Quanto mais dele se retira a possibilidade de atuar autonomamente, atribuindo decisões fundamentais a guardiões, menor será a possibilidade de desenvolver um senso de responsabilidade pelas ações coletivas. Essa opção decorreria de uma infantilização paternalista do povo, que abdica de sua autonomia para tomar decisões morais relevantes.

A defesa substantiva da revisão judicial aproxima-a do que seria um regime de guardiões. Assume que o indivíduo, no ambiente majoritário, tende a decidir

\footnotetext{
${ }^{32}$ Controle de Constitucionalidade e Democracia, pp. 25 e 129.

${ }_{33}$ Argumentei de forma semelhante na dissertação. (Cf. Controle de Constitucionalidade e Democracia, p. 128 e p. 156)

${ }^{34}$ Ibid, p. 192.
} 
irracionalmente e, para protegê-lo, retira dele essa competência. Desconfia da capacidade do cidadão passar por um procedimento majoritário. Para decidir sobre o conteúdo de tais direitos, juízes estariam em melhor condição do que indivíduos autônomos num foro eleitoral-majoritário.

Dahl demonstra empiricamente que a Corte americana só conseguiu impor alguns poucos empecilhos à decisão legislativa, os quais somente adiaram a vitória de uma maioria estável, ou impediram a vitória de uma maioria frágil e episódica. ${ }^{35}$ Essa informação empírica traz a medida de realismo com o qual a teoria constitucional deve tratar da capacidade que tem a revisão judicial, por si só, de proteger a democracia contra os perigos da política.

Esta tese dá continuidade ao projeto teórico iniciado no mestrado e dialoga com ele. Continua girando em torno de um mesmo problema e compartilha de sua perplexidade inicial: alguns lugares comuns da teoria constitucional que são evocados para explicar nosso modelo de estado merecem ser postos em xeque, pois são menos auto-evidentes do que a narrativa constitucional sugere. Desconfiar desses pressupostos nos ajuda a ter percepção mais acurada sobre a dinâmica da separação de poderes e da proteção de direitos numa democracia. O fato de sequer tematizar ou apresentar respostas a esses problemas mostra o grau de artificialidade de boa parte da teoria constitucional brasileira. Acolhidas ou rejeitadas, as objeções à revisão judicial devem ser tratadas de maneira franca e transparente, e não escondidas por argumentos que dissimulam o problema e pintam um quadro cor-de-rosa. ${ }^{36}$

A tese aceita o argumento central da dissertação, mas, ao ampliar o horizonte temporal em que pensa a política, complementa-o e, sobretudo, relativiza-o, desenvolvendo algumas intuições lá presentes. Entre duas perspectivas temporais para a análise da política, pode-se dizer que a dissertação ilumina a de curto prazo, e os problemas da definição da última palavra em cada "rodada procedimental". ${ }^{37}$ A tese,

\footnotetext{
${ }^{35}$ Esta consideração clássica de Dahl cumprirá papel importante no capítulo 4, quando discutirei o prisma do "diálogo" para entender o papel da revisão judicial.

${ }^{36}$ Uma "rosy picture", nas palavras de Waldron (Law and Disagreement, $\mathrm{p} . \mathrm{xx}$ )

${ }^{37} \mathrm{O}$ conceito de "rodada procedimental" será melhor desenvolvido nos capítulos 6 e 7. Refere-se ao circuito decisório entre os poderes até chegar a uma decisão final. Este caráter "final", porém, é também relativo e não escapa de uma inevitável provisoriedade, pois o mesmo tema pode renascer no domínio da deliberação política posteriormente, em intervalos maiores ou menores.
} 
por sua vez, aponta para a perspectiva de longo prazo e para a continuidade de tais rodadas procedimentais. Indica a inevitável provisoriedade da "última palavra", a permanência da comunidade política no tempo, o seu caráter de empreendimento coletivo que se estende, inclusive, para além de cada geração, tanto prospectiva quanto retrospectivamente. ${ }^{38}$

A tarefa que continua a ser perseguida é a formulação de um discurso de legitimidade que dê à revisão judicial o lugar mais adequado dentro da democracia. Seu desafio é encontrar um modelo normativo ambicioso e exigente, que sirva como guia tanto para orientar a atuação da corte quanto para avaliar seu desempenho. Além da necessidade de criticar decisões individuais que, isoladamente, podem ser boas ou más, precisamos de uma noção clara e consistente de qual a missão da corte nesse tipo de regime.

\section{Plano da tese}

Os três capítulos seguintes descrevem e interpretam três tipos de resposta presentes na literatura da teoria constitucional. Os dois primeiros (capítulos 2 e 3 ) correspondem a teorias preocupadas em apontar quem deve ter a "última palavra"39 sobre direitos fundamentais. Classifico essas teorias como "mais inclinadas" por cortes constitucionais e juízes ou como "mais inclinadas" por parlamentos e legisladores. A inclinação por juízes, geralmente, é baseada no que poderíamos chamar de "presunção da infalibilidade judicial" (ou da "menor falibilidade judicial por meio de deliberação genuína"). A inclinação por legisladores, por sua vez, é baseada na combinação de dois elementos usualmente associados com democracia e igualdade: regra de maioria e representação eleitoral. Teorias da última palavra, a rigor, não rejeitam algum tipo de diálogo ou interação, mas defendem que o circuito decisório possui um ponto final dotado de autoridade por meio de uma decisão soberana.

\footnotetext{
38 * Gerações passadas e gerações futuras, nossos antepassados e nossos descendentes, também contam numa democracia. V. Cecile Fabre, "Rights and Non-Existence", e Jeb Rubenfeld, Freedom and Time.

${ }^{39}$ Não sei se, dentro das classificações convencionais da relação entre parlamentos e cortes, já foi utilizada a expressão "teorias da última palavra". Considero essa denominação adequada para os fins da classificação que proponho. Ela deriva do uso abundante de expressões como "last word", "last say", "ultimate authority", "supreme authority", ou simplesmente "supremacy" na literatura a respeito.
} 
O terceiro tipo de resposta (capítulo 4) é dado por "teorias do diálogo institucional". Basicamente, essas teorias defendem que não deve haver competição ou conflito pela última palavra, mas um diálogo permanente e cooperativo entre instituições que, por meio de suas singulares expertises e contextos decisórios, são parceiros na busca do melhor significado constitucional. Assim, não haveria prioridade, hierarquia ou verticalidade entre instituições lutando pelo monopólio decisório sobre direitos fundamentais. Haveria, ao contrário, uma cadeia de contribuições horizontais que ajudariam a refinar, com a passagem do tempo, boas respostas para questões coletivas. Separação de poderes, nesse sentido, envolveria circularidade e complementaridade infinitas. ${ }^{40}$

Os capítulos 2 a 4 encerram um primeiro bloco da tese. Correspondem a um determinado modo de classificar as teorias da revisão judicial e decorrem da adoção de um critério que considero elucidativo. Trata-se, obviamente, de uma opção entre outras válidas, as quais gerariam agrupamentos diferentes. ${ }^{41}$ Como em toda classificação, simplificam-se argumentos e se os reúnem debaixo de um mesmo rótulo abstrato. Utilizo-me de uma combinação livre de diversos argumentos para construir posições estilizadas. Não proponho, necessariamente, que cada autor acomode-se integralmente às posições que concebi para fins de argumentação. Classificações não conseguem fazer justiça ao detalhe de cada teoria. Não raro, traem-na por salientar algum componente isolado e fornecendo uma idéia errada de seu ponto de chegada.

\footnotetext{
40 "Última palavra" e "diálogo" encerram uma forma conveniente de se referir ao debate para os meus propósitos argumentativos. Põe em evidência, afinal, a dimensão temporal (a tensão entre "último" e "continuidade") da política. No entanto, é mais comum a literatura constitucional referir-se, respectivamente, às expressões "supremacia" (seja judicial ou legislativa) ou "constituição fora das cortes" (que destaca o exercício da interpretação constitucional nos outros poderes).

${ }^{41}$ Alguns notarão nessa estratégia expositiva dos capítulos 2 a 4 alguma semelhança com a estruturação de Wil Waluchow para discutir a objeção democrática à revisão judicial (A Common Law Theory of Judicial Review, p. 10-11). Neste livro, o autor também conduz seu argumento em três passos: dentro do que chamou de "standard conception" das cartas de direitos, distingue entre os "Advocates" e os "Critics", e avalia o mérito relativo de cada um. Em seguida, para responder aos argumentos remanescentes dos "Critics" e resgatar os "Advocates", ele formula a "alternative common law conception". Apresenta, assim, duas versões de uma abordagem standard que faria suposições problemáticas, e propõe uma saída por meio de uma nova suposição. A seqüência, portanto, é similar com a desta tese: opõe duas posições essenciais e acha uma terceira via. A oposição inicial (conforme Waluchow, entre Critics e Advocates, e, conforme esta tese, entre os inclinados pela última palavra judicial e pela última palavra legislativa) é particularmente parecida. Meu critério classificatório, todavia, é distinto, além de adotar uma "licença poética" para radicalizar a polarização, combinando argumentos que, no conjunto, não correspondem precisamente ao que nenhum autor disse. São, portanto, posições estilizadas. A "terceira via", apresentada no capítulo 4 e depois melhor desenvolvida nos capítulos 6 e 7, tem diferenças mais marcantes. Não proponho superar as teorias da última palavra, mas sim integrá-las à perspectiva do diálogo.
} 
Cumprem, entretanto, um determinado propósito. O meu é iluminar um aspecto particular que suponho ainda não ter sido bem explorado na discussão.

Os capítulos 2 e 3 reformulam, grosso modo, as posições gerais por trás da interface entre Dworkin e Waldron da dissertação. Esses dois autores continuam a ser os personagens-símbolo das duas posições antagônicas, ainda que a oposição esteja mais robusta e o argumento de cada lado mais abrangente. Do lado das teorias do diálogo, no capítulo 4, Alexander Bickel mereceria tal título, não tanto por ter articulado todo um argumento a respeito, mas por haver inaugurado essa percepção sobre o papel da corte. A teia de argumentos tornou-se mais variada. Em vez do cotejo entre poucos autores, tento promover a interpretação e sistematização de grandes posições. Pretendo, assim, montar as peças de um edifício mais completo e que propicie uma visão de mais longo alcance.

O capítulo 5 fará um breve desvio para analisar como esses três tipos de resposta lidam com uma afirmação convencional da sabedoria política sobre desenho institucional (também já explorada na dissertação). Segundo essa afirmação, instituições são falíveis. Mesmo os melhores e mais cautelosos procedimentos estão sujeitos ao erro. Rawls chamou essa fatalidade da política de "justiça procedimental imperfeita". ${ }^{42}$ Se isso é verdade, supõe-se que a disputa pela "última palavra" é uma disputa em torno do direito de errar por último. Como um auto-governo genuíno envolveria o direito do povo de aprender e assumir responsabilidade pelos próprios erros, a teoria democrática teria a responsabilidade especial de demonstrar que a instituição encarregada da última palavra promove esse efeito. A perspectiva dialógica, por outro lado, diluiria essa preocupação por meio de uma cadeia de diferentes decisões distribuídas no tempo. A preocupação com a última palavra, nesse sentido, seria equivocada e a idéia de um direito de errar por último um nonsense, ou, no mínimo, uma visão limitada e de curto prazo.

O capítulo 6 avaliará o quanto há de complementariedade entre a perspectiva do diálogo e as teorias orientadas pelo foco na "última palavra", e o quanto esse prisma adicional ajuda a resolver a objeção do déficit democrático da revisão judicial. $\mathrm{O}$ argumento da tese propõe que o diálogo, per se, pode ser uma resposta fácil que ${ }^{42}$ Rawls, $A$ Theory of Justice, p. 85. 
subestima os críticos da revisão judicial por meio de uma imagem que, apesar do mérito de colocar a discussão num prisma mais aberto e flexível, não resolve todas as preocupações por trás daquelas objeções. Além disso, a imagem do diálogo esconderia a dimensão do conflito e da necessidade de decisão nas circunstâncias de desacordo. Esse olhar conciliatório e contemporizador sobre a política traria o risco de obscurecer um elemento importante que uma teoria consistente da separação de poderes precisa levar em conta.

Em outras palavras, dizer que a revisão judicial não tem a última palavra, já que as instituições estão dialogando e a história continua, não enfrenta a constatação óbvia de que nem todos os tipos de diálogo são aceitáveis na democracia e que cada decisão coletiva tem custos e efeitos que precisam de justificativa adequada. Entre tais custos, algumas teorias do diálogo subestimam especialmente o "custo temporal" de novas "rodadas procedimentais". Apesar da importância do prisma do diálogo para colocar a separação de poderes numa perspectiva diacrônica e dinâmica, e além de lançar luzes na deliberação inter-institucional que, de um modo ou de outro, ocorre, a preocupação subjacente às "teorias da última palavra" - mesmo que "última palavra" seja uma expressão que induz a mal-entendidos - ainda fornece um dos princípios operativos pelo qual podemos pensar em modelos de diálogo que sejam normativamente mais desejáveis na democracia.

Há um momento em que a deliberação precisa se encerrar e abrir espaço para uma decisão em face de um desacordo persistente. Dentro do processo legislativo (ou mesmo num tribunal), isso se resolve pelo voto. Quando um desacordo persistente ocorre entre diferentes instituições, parece importante encontrar um caminho que o resolva, ainda que temporariamente. Por trás dessa preocupação, há um imperativo do estado de direito (rule of law). Assim, uma teoria que não esconda o desacordo e tente decompor analiticamente tipos de conflito institucional, tipos de diálogo correspondentes e maneiras de encontrar soluções temporárias legítimas, seria uma forma mais frutífera de teorizar sobre separação de poderes.

O capítulo 7 cumprirá a tarefa de conceituar padrões normativos para modelos mais desejáveis de diálogo. Num nível mais abstrato, diálogo ecoa o tema clássico da “deliberação" no pensamento político, ou do método decisório por meio do argumento 
e do debate, explorado recentemente por teorias da democracia deliberativa. Essas teorias oferecem uma orientação sobre como conceber condições da deliberação genuína. O foco da tese será a deliberação inter-institucional (entre parlamentos e cortes) ao invés da deliberação intra-institucional (dentro de parlamentos e cortes). As condições deliberativas dentro de cada instituição são recursos importantes de legitimação, mas a perspectiva inter-institucional me parece ter uma relevância própria ainda sub-explorada.

Os capítulos 6 e 7 articulam-se para problematizar e qualificar a pergunta sobre a medida e os termos nos quais a última palavra sobre direitos fundamentais é um dilema da teoria democrática. Argumento que, ao frasear o problema numa lógica do "tudo ou nada", a pergunta não capta a dinâmica da política. Além disso, proponho que o dilema real e mais importante da teoria democrática, em relação a esse aspecto, não é a escolha de uma ou outra instituição como a última autoridade legítima. Em vez disso, o desafio é desenhar um diálogo que maximize a capacidade da democracia de produzir respostas melhores em direitos fundamentais ou, em outras palavras, de levar o potencial epistêmico da deliberação inter-institucional a sério, sem desconsiderar a necessidade do estado de direito por decisões estáveis, ainda que provisórias.

Em suma, a tese continua tendo, tanto quanto a dissertação, uma natureza exploratória. Possui uma parte interpretativa, que tenta descrever e sistematizar as principais características das teorias da última palavra e do diálogo, e uma parte mais construtiva e ensaística, que visualizo em três passos conectados: a articulação entre última palavra e diálogo dentro da separação de poderes (capítulo 6); a demonstração do papel potencial da deliberação entre instituições como critério normativo que qualifica este arranjo (capítulo 7). Promove um mapeamento de uma multiplicidade de problemas e argumentos e tenta caminhar para algumas soluções. Procura desenhar o quadro geral do debate e oferecer a moldura macroscópica do que está em jogo quando se discute o papel do legislador e do controle de constitucionalidade na democracia. Passa por uma série extensa de autores, mas o argumento e seu percurso não se confundem com nenhum deles. 
Tento contribuir para o desenvolvimento de uma teoria normativa da interação entre parlamentos e cortes na busca da proteção de direitos numa democracia constitucional. Como qualquer teoria política normativa, seu desafio é prescrever princípios mais desejáveis de desenho e comportamento institucional, e oferecer critérios para a crítica e a reforma políticas. Ao prescrever "princípios desejáveis", precisa encontrar o equilíbrio apropriado entre realismo e idealismo. Precisa ser idealista para imaginar aquilo que ainda não necessariamente existe, de modo a cumprir sua missão crítica e transformadora. Mas precisa ser realista para que a realidade política imaginada seja alcançável. Não está ao alcance dessa teoria perceber, a priori, a factibilidade e a viabilidade de suas ambições normativas. A calibração dessa "realidade imaginada e alcançável, apesar de ainda não existente" é inevitavelmente uma aposta, a ser testada pelo intercâmbio intelectual e pela história (teste que, porém, nunca será peremptório).

\section{Algumas digressões metodológicas}

Explicito e comento alguns princípios de trabalho. Eles tocam em problemas que muitas obras de teoria política articulam tacitamente. Tal explicitação facilita, talvez, a leitura crítica da tese, ao indicar alguns critérios a partir dos quais ela pode ser testada. Mais do que isso, fornece ao próprio autor um guia ao qual pode recorrer na elaboração do texto.

Não é comum falar em metodologia quando da elaboração de argumentos de teoria política normativa. Afinal, fazemos simplesmente isso - elaborar argumentos sobre modelos racionalmente mais defensáveis de organização política. Nesse exercício, não nos dirigimos ao "mundo real" com um conjunto de procedimentos técnicos e quantitativos rigorosamente predefinidos (mesmo que informados por categorias normativas) para descobrir como ele está funcionando e a partir daí lançar generalizações, explicações causais etc. No entanto, escolhas de método, mesmo que menos aparentes, obviamente ocorrem e condicionam a construção de qualquer argumento normativo, cuja qualidade dependerá, entre outras coisas, de sua coerência com tais escolhas. 


\subsection{Suposições e implicações: o que está nas entrelinhas?}

Saber se a revisão judicial é compatível, e, se for, em que medida, com o ideal democrático é uma das questões mais debatidas da teoria constitucional no século XX. Seria legítimo, em nome da constituição, que juízes não eleitos e não sujeitos à responsabilização política revoguem legislação editada por um parlamento eleito pelo povo, especialmente se aceitamos que a interpretação constitucional é aberta ao julgamento moral e ao desacordo? Qualquer resposta necessariamente carregará um estoque de suposições. Elas estarão conectadas, entre outras coisas, com: os significados e valores da democracia e do constitucionalismo; o papel da representação eleitoral; o esquema de prioridades entre procedimentos decisórios eqüitativos e resultados justos; as capacidades decisórias de juízes e legisladores e os valores por trás da legislação e da adjudicação; e os arranjos concretos sob discussão.

Podemos certamente escavar mais camadas e alcançar questões mais fundantes da ética e da política, de onde derivam as acima enumeradas. A não ser que fosse possível uma teoria abrangente e completa da moral, da política e do direito, que costurasse e exaurisse todos os níveis, entre as fundações primeiras até as implicações últimas de cada argumento, há que se escolher uma porta de entrada, uma de saída e um determinado caminho para enfrentar essa rede de conexões conceituais. Com o que estamos comprometidos no ponto de partida? O que comprometemos no ponto de chegada? Essa é uma das inquietações recorrentes que perturbam qualquer teórico, por mais que tente "delimitar o objeto" com clareza e de modo consciente. O ato de demarcar o terreno é, em si, problemático e sujeito a críticas, tanto internas quanto externas. Não há como evitar, por tudo isso, que muito permaneça implícito num argumento teórico, que muito fique não dito para trás, e muito a ser dito para a frente.

Essas colocações, provavelmente triviais, são ilustrativas para lidar com o debate desta tese. A literatura sobre revisão judicial é particularmente recheada de suposições silenciosas e mal percebidas, sejam elas inconscientes, sejam elas deliberadamente escondidas ou ignoradas. Duas das mais perigosas, talvez, decorrem de um passo que embute numa instituição um determinado ideal político. Particularmente, o que fundiu democracia, ou mesmo "povo", a parlamento representativo, e constitucionalismo e proteção de direitos a mecanismos anti- 
majoritários, especialmente o judicial. Esta segunda inferência foi bastante discutida na dissertação. A primeira permaneceu intocada. Se, de um lado, o "pequeno segredo sujo" ${ }^{43}$ por trás da defesa do papel da corte constitucional foi lá denunciado, de outro, o discurso equivalente que sobrepõe "vontade do povo" ou "auto-governo" à "vontade da maioria no parlamento representativo" não foi lá enfrentado, mesmo porque o texto não pretendeu fazer uma defesa positiva do órgão legislativo como conseqüência daquela denúncia.

O tópico 5 abaixo, ao propor um modo de estruturar o pensamento sobre a separação de poderes, organiza alguns dos níveis em que essa discussão tradicionalmente se situa, e, assim, tentará abrir mais um pouco a couraça dentro da qual os argumentos às vezes permanecem. O que supõem as teorias da última palavra, seja a inclinada por legisladores e parlamentos, seja a inclinada por juízes e cortes? O que supõem as teorias do diálogo? Quais as implicações que ambas produzem para o desenho institucional? É possível conciliá-las? Estas perguntas orientam o caminho da tese.

Há, ainda, outra cautela relevante. A maioria dos autores com os quais lidarei participa de um debate geograficamente localizado, que faz suposições particulares. Para lidar com isso, delineio algumas estratégias nos dois tópicos seguintes.

\subsection{A hegemonia da literatura norte-americana}

"Literatura sobre revisão judicial", até poucos anos atrás, praticamente se confundia com a "literatura norte-americana". Consistia numa bateria de soluções para a "dificuldade contra-majoritária", contraposta a reformulações periódicas da objeção democrática. Apesar da aparência de haver atingido o estágio da exaustão argumentativa, renovações constantes dos dois lados continuam a surgir. Ao menos no que diz respeito à teoria normativa, a quantidade de argumentos alcançou um grau considerável de complexidade e diversidade. A maioria dessas ondas teóricas que periodicamente reinterpretaram o problema teve um atávico caráter paroquial: com freqüência, pressupuseram o modelo americano de revisão judicial. ${ }^{44}$ Reduziam-se a

\footnotetext{
${ }^{43}$ Expressão de Unger citada por Waldron na introdução de Law and Disagrement.

${ }^{44}$ Waluchow, por exemplo, também observou essa característica: "Oftentimes discussions of judicial review under a Charter presuppose the American paradigm and proceed as though this example defines
} 
discursos que conferiam ou retiravam legitimidade da Suprema Corte americana. Isso é compreensível, uma vez que boa parte estava preocupada, de fato, com tal sistema particular.

Uma rápida compilação das expressões que compõem a retórica anti-revisão judicial mostra o acento norte-americano: "grupo de guardiões platônicos", "reisfilósofos" ("bevy of Platonic Guardians", "philosopher kings”), “oráculo constitucional" (“constitutional oracle"), "oráculos do direito" (“oracles of law”), "censores morais da escolha democrática" ("moral censors of democratic choice"), "ideólogo da democracia americana" ("ideologue of the American democracy"), "confraria de guardiões da verdade moral", "conselho sábio de tutores na verdade moral" ("coterie of guardians of the moral truth", "wise council of tutors in moral truth"), "profeta moral” (“moral prophet"), "oligarquia judicial” ("judicial oligarchy"), "juristocracia" ("juristocracy") 45 etc. Do outro lado, para enfrentar o volume e a eloqüência desses ataques, Dworkin impôs o heróico "Hércules", capaz de deliberações exemplares no "fórum do princípio".

O paroquialismo, portanto, é uma das principais marcas de parte dessa literatura. Christopher Zurn percebeu algumas de suas peculiaridades. Segundo ele, ela teria que obedecer uma série de limites argumentativos. Quem não os respeitar estaria fadado ao limbo acadêmico e político. Entre tais limites, está o que chamou de "panglossianismo institucional” (“institutional panglossianism”), um "amálgama entre fato e valor", a avaliação de que a revisão judicial é um dado imutável da história e representa o "melhor mundo possível". ${ }^{46}$ A existência mesma da instituição, nos Estados Unidos, não está em disputa, mas apenas o "como" operá-la. ${ }^{47}$

the wider phenomenon. It is often assumed, for example, that the decision of a supreme court to overturn legislative decisions is absolute, thus raising and colouring our attempts to answer questions about the consistency of judicial review with democratic principles. Yet as Section 33 of the Canadian Charter illustrates, there is no necessity here. It is possible to have judicial review without granting judges the final say". (Cf. A Common Law Theory of Judicial Review, p. 12)

${ }_{45}$ Essas expressões são encontradas, na seqüência, nos seguintes autores: Learned Hand, Dawson, Stephen Perry, Antonin Scalia, Robert Cover, Christopher Zurn, Rainer Knopf, Wil Waluchow e Ran Hirschl. Os últimos quatro, é verdade, não são norte-americanos, mas participam do mesmo debate.

${ }^{46}$ Cf. Deliberative Democracy and the Institutions of Judicial Review, p. 9-10 (voltarei a essa passagem no capítulo 6).

${ }^{47}$ Cf. Controle de Constitucionalidade e Democracia, p. 111-114. 
Esse debate, por mais plural que seja, teria, portanto, um ponto de partida razoavelmente empobrecido. Quando os seu termos começam a influenciar outras jurisdições sem as devidas adaptações, como se fossem de validade universal tout court, esse anacronismo analítico pode debilitar a possibilidade de uma reflexão contextualizada que sustente comparações e importações construtivas. Nas últimas décadas, devido ao fato de que esse arranjo institucional foi exportado para várias democracias constitucionais, e que o poder judiciário ocupou um papel político mais proeminente enquanto fórum central para demandas coletivas, a "questão americana" tornou-se mais universal. A tentativa de resolver a "dificuldade contramajoritária" influenciou até mesmo o próprio desenho de alguns novos regimes constitucionais. Alguns países criaram o que se convencionou chamar de "formas fracas" de revisão judicial, como Canadá, Reino Unido e Nova Zelândia. ${ }^{48}$ Em paralelo a esse processo político, o debate acadêmico constantemente se reinventou.

A crítica segundo a qual a literatura americana não se aplica a qualquer contexto, portanto, chama a atenção para aspecto importante. Tal literatura pode, eventualmente, ofuscar, direcionar e distorcer os termos do problema. Justamente por esses riscos, não deve ser apropriada sem os devidos cuidados e mediações, mas tampouco rejeitada sumariamente. É quase inevitável passar por ela: eles inventaram a instituição, formularam a pergunta e elaboraram as principais respostas. Mesmo pelo seu imenso volume, essa literatura às vezes desencoraja um ponto de vista diferente. Seria muito custoso demonstrar que todo esse colossal esforço estava simplesmente fazendo a pergunta errada. Mas não se trata, obviamente, de volume. Substancialmente, o que vem a reboque da importação desse debate? Quais são os tais cuidados e mediações? Eles fornecem a pergunta certa para o caso brasileiro? ${ }^{49}$

A transposição de tais lentes hegemônicas para o Brasil requer, no mínimo, que se leve em conta os seus pressupostos e que se verifique sua compatibilidade com a democracia constitucional brasileira. Quais são esses pressupostos? Um deles, obviamente, é o específico desenho institucional em que a Suprema Corte se insere.

\footnotetext{
${ }^{48}$ Cf. Stephen Gardbaum, "The New Commonwealth Model of Constitutionalism".

${ }^{49}$ A literatura de ciência política comparada parece sofrer também dessa miopia analítica, ao adotar como principal categoria classificatória a distinção entre parlamentarismo e presidencialismo. Fernando Limongi mostra o erro dessa estratégia. (Cf. "A Democracia no Brasil: Presidencialismo, coalizão partidária e processo decisório")
} 
Para lidar com ele, proponho o isolamento das variáveis institucionais, estratégia explicada no próximo tópico. Mas não é somente isso. $\mathrm{O}$ desenho institucional é precedido por determinada teoria e história políticas que provocaram seu nascimento e influenciaram seu desenvolvimento por mais de dois séculos. História e teoria singulares não impedem, todavia, que aquela experiência seja exportada, como de fato o foi na transição republicana brasileira no final do século XIX. ${ }^{50}$

\subsection{Isolamento das variáveis institucionais}

Retomo aqui algumas cautelas já esboçadas na dissertação. Tento perceber, dentro da variedade de argumentos, quais são dependentes do contexto, quais são locais e quais "universais". O mínimo denominador comum de todos os sistemas de controle de constitucionalidade, nos quais faz algum sentido debater a legitimidade democrática, é um "fato cru"51: um arranjo institucional que permite ao poder judiciário, em algum momento e com alguma intensidade, revogar, a título de incompatibilidade com a constituição, uma lei editada pelo parlamento representativo. ${ }^{52} \mathrm{O}$ STF, é bom lembrar, tem competência para exercer dezenas de funções, enumeradas no art. 102 da Constituição Federal. Estou discutindo, porém, somente aquela que é politicamente mais impactante (art. 102, I, “a”). ${ }_{53}{ }_{-}^{54}$

\footnotetext{
50 Várias considerações a respeito também foram feitas na dissertação. (Cf. Controle de Constitucionalidade e Democracia, pp. 27-28, 111-112 e 191)

${ }^{51}$ Controle de Constitucionalidade e Democracia, p. 19-21. No capítulo 8 dessa tese farei alguns comentários adicionais à aplicabilidade do debate no Brasil em face de nossas particularidades institucionais. As cautelas exaustivamente enumeradas na dissertação não serão aqui repetidas, mas aplicam-se igualmente.

${ }^{52}$ Wil Waluchow, por exemplo, promoveu delimitação parecida: "To that end, the analysis purports to be relevant to any democratic country or jurisdiction in which one finds some form of Charter limitation on government action - that is, in which governments are in some way, and to some extent, required or expected, when exercising their (typically legislative) powers, not to infringe on a constitutionally specified set of moral rights". (Cf. A Common Law Theory of Judicial Review, p. 12)

${ }^{53}$ Art. 102. Compete ao Supremo Tribunal Federal, precipuamente, a guarda da Constituição, cabendolhe: I - processar e julgar, originariamente: a) a ação direta de inconstitucionalidade de lei ou ato normativo federal ou estadual e a ação declaratória de constitucionalidade de lei ou ato normativo federal.

${ }^{54}$ Zurn faz comentário parecido: "Like other exercises in normative theory, this book will assume certain simplifications of the workings of actual constitutional democracies in order to focus on underlying ideals of constitutional democracy and their competing conceptualizations. One of the most important of these simplifications is to focus the arguments around the question of only one of the functions captured in the phrase 'judicial review'. In the U.S. judicial system, for example, the Supreme Court has many different roles and carries out many different functions. At least five can be analytically distinguished. (...) Finally, fifth, the Supreme Court has the authority to review national ordinary law (...) When I refer throughout this book to 'judicial review', I am referring most centrally only to the fifth category of functions (...). For it is in carrying out this fifth function that the tensions between judicial review and democracy are felt to arise most acutely". (Cf. Judicial Review and the Institutions of Deliberative Democracy, p. 26-27)
} 
Essa seria a essência da invenção americana, independentemente das múltiplas variações que sofreu no processo de transplante para outros países. Transcender detalhes institucionais e eliminar argumentos particulares é o primeiro passo para que essa literatura possa circular de modo mais desenvolto por outras jurisdições, para que tenha maior versatilidade e evite qualquer miopia ou anacronismo teórico. É desejável construir artificialmente um terreno no qual a discussão se torne universal? Qual o valor ou efeito dessa simplificação? Não tornaria os argumentos tão abstratos que fariam o objeto concreto perder sua identidade e cair num vácuo? Não seria um esforço estéril?

A redução do objeto a um "fato cru" perde, de fato, as nuances institucionais que configuram desafios diferentes para a legitimidade democrática das cortes de cada país. A discriminação e classificação dessas variações são, sem dúvida, importantes. Apesar dessas perdas, esse é um corte necessário se pretendemos nos beneficiar da riqueza da literatura estrangeira.

\subsection{Binarismo e gradualismo na teoria política e jurídica}

Há duas maneiras de se pensar em conceitos políticos e jurídicos que se manifestam em diversas partes desse texto. Poderíamos chamar esses dois estilos analíticos de binarismo e gradualismo. Binário é o raciocínio estruturado a partir de dicotomias abrangentes e rígidas, isto é, limita-se a verificar se um objeto tem ou não determinada qualidade (por exemplo: se um regime é democrático ou autoritário, se alguém é de esquerda ou de direita, se uma lei é constitucional ou inconstitucional). Gradualista, por sua vez, é o raciocínio que nos permite avaliar a medida de certa qualidade, o grau de realização de determinado ideal. Não se preocupa em dizer se algo é ou não é, mas em que medida algo é ou não é, o quanto se aproxima ou se distancia desse ideal (da democracia, da esquerda e assim por diante). Não se acomoda, nesse sentido, à definição do modelo ideal, mas desenvolve parâmetros de mensuração e defende que pontos mais próximos do ideal são, obviamente, mais desejáveis. ${ }^{55}$ Verbos como maximizar e minimizar, aproximar e distanciar, aumentar e

\footnotetext{
${ }^{55} \mathrm{O}$ gradualismo é metodologia recorrente em modelos empíricos da ciência política. A estratégia argumentativa de conceber dois extremos e indicar que situações reais se localizam em algum ponto
} 
diminuir, favorecer e desfavorecer, aperfeiçoar e piorar, progredir e retroceder são os mais apropriados para uma análise gradualista.

Formulado dessa maneira, parece certo que o gradualismo é uma forma mais produtiva de se apresentar perguntas, problemas e respostas na análise política. ${ }^{56}$ Teria maior potencial explicativo e aderência à diversidade dos objetos no mundo real. Permitiria pensar na qualidade da democracia, em mais e menos, em melhor e pior, em pontos intermediários de um contínuo. Seria mais sensível e atento a sutis mudanças de grau, a transformações incrementais na qualidade de determinado objeto. O binarismo, por outro lado, nos prenderia a uma camisa-de-força cognitiva, à armadilha maniqueísta do tudo ou nada, que opõe preto e branco sem notar zonas cinzentas intermediárias. ${ }^{57}$

intermediário do espectro é bastante freqüente. Gráficos e tabelas são também instrumentos comuns para representar espacial ou quantitativamente os graus, as múltiplas dimensões etc. Que serviço o gradualismo pode prestar à teoria normativa? Remeto-me aqui a uma observação de Virgílio Afonso da Silva feita no exame de qualificação (18.07.2008). Numa paráfrase: "Para ser normativo, não há como escapar do binarismo. O gradualismo é mais efetivo no exercício descritivo". Essa afirmação merece ser qualificada. A teoria normativa tem que ser sensível a gradações justamente para mostrar que um ponto mais próximo do ideal é melhor do que o mais distante. O normativo, por isso, deve não apenas modelar o ideal (e nesse sentido, imagina os dois extremos do espectro), mas também imaginar os graus de aproximação. É necessário, por exemplo, ter um argumento normativo para defender a democracia que temos, a qual, apesar de longe do ideal, é provavelmente melhor do que as alternativas vistas na história brasileira. Esse "contínuo", com graus crescentes de qualidade, é fornecido pela teoria normativa.

${ }^{56}$ Ian Shapiro apontou para a mesma tensão no campo da política: "Conceiving democracy as a means for limiting domination offers several advantages. First, it poses normative questions about democracy in a 'compared to what?' framework, because democracy is now judged not by the either/or question whether it produces social welfare functions or lead to agreement, but rather by how well it enables people to manage power relations as measured by the yardstick of minimizing domination. Second, this approach invites us to avoid another kind of binary thinking: about democracy itself. Ways of managing power relations can be more or less democratic. It is one of the singular contributions of Dahl's idea of poliarchy that it turns questions about democracy into more-or-less questions rather than. whether-or-not questions". (não há grifos no original) (Cf. The State of Democratic Theory, p. 51)

${ }^{57}$ Vários autores importantes podem exemplificar o que estou dizendo, além de Robert Dahl e seu conceito de poliarquia, já mencionado por Ian Shapiro em nota acima. Lon Fuller, por exemplo, em The Morality of Law, tem em mente exatamente essa idéia quando propõe que o estado de direito é um empreendimento teleológico (purposive enterprise), uma questão de grau, uma busca incessante pela otimização dos princípios inerentes à moralidade interna do direito (inner morality of law). Max Weber consagrou a metodologia de propor "tipos ideais" ao se analisar as modalidades de legitimidade (legalracional, tradicional e carismática). Ronald Dworkin e Robert Alexy introduziram também metodologia parecida para se pensar na normatividade dos princípios jurídicos. A racionalidade jurídica, em si, estaria presa a essa camisa-de-força maniqueísta: legal e ilegal, válido e inválido, constitucional e inconstitucional. Essas categorias não estariam sujeitas a considerações de mais ou menos. Dworkin e Alexy, porém, em suas teorias sobre princípios, ponderação balanceamento, abalaram um pouco esse esquema mental. Por fim, mencionaria também a obra organizada por Neil MacCormick e Robert Summers, que desenvolveram uma forma de comparar a normatividade de precedentes judiciais em diversos países (bindingness as matter of degree). 
Antes de se rejeitar o binarismo, pura e simplesmente, certas nuances devem ser levadas em conta. Costuma haver, no gradualismo, um elemento binário sem o qual ele não consegue operar. Ele não abre mão, na maioria das vezes, de dicotomias, mas as submete a um tratamento diferente: em vez de girar em torno de duas categorias estanques, pega-as emprestada e as trata como tipos-puros, que jamais se realizam por inteiro na realidade, mas em diferentes graus. ${ }^{58}$ Além disso, a estratégia gradualista precisa postular e convencionar alguma fronteira, algum limiar a partir do qual o objeto estudado passa a estar mais próximo de um dos extremos do contínuo (o limiar a partir do qual, por exemplo, um regime deixa de ser chamado de autoritário e passas a ser considerado democrático).

A própria dicotomia entre "binarismo" e "gradualismo", se não feitos tais esclarecimentos, pode transformar-se numa armadilha binária. O objetivo dessa digressão é indicar a forma pela qual a tese procurará escapar de tal armadilha quando diante das diversas dicotomias que perpassam o problema aqui estudado. Como o conceito de democracia política é o subtexto desse trabalho, algumas considerações adicionais ajudam a clarear esse ponto.

A idéia de democracia é o centro de gravidade da imaginação política contemporânea. Regimes políticos são avaliados, sobretudo, por referência às múltiplas dimensões desse conceito que se decompõe, entre outras coisas, em demandas por igualdade, respeito a direitos, participação e certos arranjos institucionais estruturados por uma constituição. Já é lugar comum afirmar que, no século XX, a democracia passou a liderar a competição pelos índices de legitimidade da política e atingiu, praticamente, consenso quanto ao seu valor abstrato. Esse consenso em abstrato, contudo, segundo esse mesmo lugar comum, foi conquistado ao preço de grande desacordo sobre as formas concretas de se implementar esse ideal.

Provavelmente, entre as causas desse fenômeno estão a maleabilidade e o poder de sedução desse conceito para, em diferentes versões, atrair e incorporar outros

\footnotetext{
${ }^{58} \mathrm{O}$ gradualismo torna-se, é verdade, mais complexo e multi-dimensional quando entram na análise diversos valores (cada um deles, por sua vez, traduzido em jogos binários num nível mais elementar). Nesse plano multi-dimensional, recorre-se ao balanceamento entre os diversos valores, que não se realizam em grau máximo se não à custa de outros também importantes. Esse acréscimo de complexidade exigiria outras considerações. Para os fins desse tópico, porém, basta a percepção do caráter gradualista ou estático na análise de antinomias nos conceitos políticos e jurídicos.
} 
ideais sensíveis da história política (como igualdade, liberdade e justiça). Todavia, essa mesma maleabilidade e alta demanda normativa, como anotado acima, gerou um acordo de superfície e um grande desacordo de bastidores. Democracia é, no plano da política, a expressão mais exemplar de "conceito essencialmente contestado", ou seja, um conceito que não provoca apenas um desacordo periférico, acidental e marginal, passível de solução após um processo de investigação racional mais esforçado. A disputa sobre o seu sentido concreto e seu caráter escorregadio é da sua essência mesma. O desacordo é infinito e opõe posições genuínas e defensáveis. ${ }^{59}$

Também por essa razão, a estratégia gradualista parece ser mais adequada para lidar com "conceitos essencialmente contestados". Trata-se de uma postura interessante para amenizar desacordos e enxergar complementaridades entre diferentes abordagens de democracia, em vez de postular uma definição rígida que exclui as alternativas. Democracia, na perspectiva gradualista, é um processo contínuo, um empreendimento coletivo permanente, que estará sempre incompleto, sujeito a avanços mas também a retrocessos. Pensar em gradações a partir de um tipopuro ideal permite notar o caráter inacabado deste projeto político, que não se paralisa com a realização de eventuais requisitos mínimos (que ultrapassam o limiar do continuum). A estratégia binária, por outro lado, permanece refém seja do minimalismo, que induz à acomodação diante da realização de um conceito mínimo de democracia, seja do maximalismo, que leva à resignação diante da impossibilidade de alcançar um critério muito exigente.

Há muitos exemplos de dicotomias que orientam nosso vocabulário político e jurídico. Algumas delas permeiam esse projeto. Listo as principais delas, algumas já mencionadas nesse capítulo. Nem todas participam igualmente no argumento central da tese, mas a apresentação de todo o conjunto consegue provavelmente reunir a grande maioria dos enfoques propostos pelas teorias da revisão judicial.

A primeira é a tensão entre forma e substância, entre o processo (input) e o resultado decisório (output). Diferentes teorias da democracia divergem em relação aos ingredientes formais e substantivos desse regime. Algumas simplificaram esse dilema e optaram por um dos lados. Outras tentaram mesclar ambos os elementos:

\footnotetext{
${ }^{59}$ Ver W.B. Gallie, "Essentially Contested Concepts".
} 
"procedimentalistas" que não abrem mão de alguma substância e "substantivistas", como Dworkin, que não abdicam de algum procedimento. ${ }^{60}$

A segunda oposição, que se parece e se relaciona intimamente com a anterior, mas com ela não se confunde, há entre decisão e razão, força e justificação, coerção e argumento, imposição e persuasão. ${ }^{61}{ }^{62}$ Estes são dois pólos de uma espinha dorsal da teoria política e jurídica e decorrem de um esforço para entender o dever de obediência às normas. Dentro de uma tradição que concebe a política e o direito como empreendimento racional, uma tentativa de cumprir a promessa do governo das leis, passa a fazer sentido analisar e criticar as razões que acompanham as decisões políticas. As decisões, nesse sentido, não são apenas ordens às quais se deve obedecer calado, mas um conjunto de razões que podem ser discutidas e que constrangem a discricionariedade do agente decisório. Um desdobramento dessa dicotomia suscita a inteface entre o ato de manifestação da vontade política (o voto) e o processo de formação da vontade política (o que vem antes e depois do voto, continuamente), distinção importante para teorias da democracia deliberativa, como veremos no capítulo 7.

A terceira, que facilmente se pode derivar da anterior, ocorre entre formal (ou institucional) e informal (ou não-institucional), imperfeitamente traduzida pelo

\footnotetext{
${ }^{60}$ Álvaro de Vita fraseia a dicotomia de forma diferente. A oposição entre forma e substância, para ele, corresponde à oposição entre ética e política: "O procedimentalismo eqüitativo oferece uma interpretação da autoridade política legítima, cujas decisões têm uma pretensão pelo menos prima facie a reclamar a obediência dos cidadãos. Já o liberalismo igualitário tem a ambição de oferecer orientação aos julgamentos dos cidadãos (e seus representantes) que agem sob uma dada estrutura de autoridade política e de oferecer um critério com base no qual avaliar a justiça dos resultados de procedimentos decisórios eqüitativos na política. E se eles têm ambições distintas, e se aplicam a coisas distintas, também não podem ser considerados - o procedimentalismo eqüitativo e a justiça rawlsiana concepções alternativas da mesma coisa. Isso, em meu entender, é somente uma das manifestações de uma distinção ainda mais fundamental (tal como a entendo) entre ética e política". "Sociedade Democrática e Democracia Política".

${ }^{61}$ Uma forma sutilmente diferente de formular essa dicotomia, que será importante para entender uma certa concepção de separação de poderes nos caps. 6 e 7, é opor a separação de poderes como, de um lado, uma confrontação uni-direcional e monolítica, uma disputa, um "braço de ferro" ou um jogo de soma zero, e, de outro, como negociação, acomodação, balanceamento e barganha para alcançar um acordo, um equilíbrio. Nessa segunda visão, o produto final é resultado da interação, não da prevalência do mais forte ou do vencedor. O resultado, portanto, é diferente da vontade de qualquer das partes. Teorias da última palavra destacam a dimensão do conflito na política, querem saber quem tem autoridade para decidir em circunstâncias de desacordo. Teorias do diálogo, por sua vez, destacam a cooperação. Veremos que não são, necessariamente, abordagens excludentes, mas percebem dimensões diferentes.

${ }^{62}$ Lon Fuller, analisando Benjamin Cardozo, nomeou essa antinomia de "reason and fiat" (Cf. "Reason and Fiat in Case-Law")
} 
paralelo entre explícito e implícito, ou também entre o escrito e o não-escrito. Trata-se de um foco importante para perceber e observar o argumento da tese sobre a deliberação inter-institucional. Não há democracia, ou mesmo política, obviamente, sem diálogo, e esta imagem se aplica às mais diversas instâncias formais e informais de uma comunidade. Nesta tese, quero observar uma espécie formalizada de diálogo, sem perder de vista ou fechar-se para os elementos informais do processo.

A quarta ocorre entre realismo e idealismo, às vezes associada, imprecisamente, à oposição entre pessimismo e otimismo, e outras à tensão entre teoria empírica ou positiva e teoria normativa. Essa é uma opção metodológica ainda mais profunda de certas correntes da teoria política que escolhem um dos lados para derivar suas explicações e exigências. Um ponto de partida comum é a suposição antropológica, a noção de natureza humana. Uma teoria normativa, como já dito, precisa encontrar algum balanço entre essas duas variáveis.

A quinta, como componente mais explícito do argumento central da tese, se dá entre as idéias de última palavra e diálogo. A literatura hegemônica que se preocupou em discutir a legitimidade democrática da revisão judicial está inspirada claramente na preocupação com a última palavra, dilema cuja solução sugere duas opções excludentes: juiz ou legislador. A preocupação com diálogo pretende escapar desse cacoete. Nessa tese, porém, ambos os pólos (diálogo e última palavra) cumprem algum papel na forma de se entender a separação de poderes.

A sexta, estritamente associada à anterior, estrutura a dimensão temporal da política em perspectivas de curto prazo e longo prazo. Outras formas de se referir a essa mesma idéia seriam as oposições entre sincrônico e diacrônico, estático e dinâmico. A tese propõe que, vista a separação de poderes a partir da primeira perspectiva, últimas palavras de fato existem, apesar de sua provisoriedade, percepção que somente a visão de longo prazo, a percepção da política como um processo contínuo, consegue alcançar. As duas perspectivas temporais, dessa maneira, cumprem algum papel. A primeira para mostrar que há últimas palavras que, apesar de provisórias, são duradouras. A segunda para indicar que após uma decisão, o 
processo político não chega ao fim, a comunidade política continua a escolher rumos e estabelecer metas para o futuro. ${ }^{63}$

A sétima diz respeito ao jogo entre ações (ou reações) e omissões na política. ${ }^{64}$ Essa dicotomia se associa, mas não se sobrepõe, à tensão entre conservação e mudança, continuidade e ruptura. ${ }^{65}$ Nesse caso, a conservação de certa decisão política não significa manutenção de determinado status quo social - a sociedade pode estar num turbulento processo de transformação enquanto a política permanece inerte. ${ }^{66}$ Da mesma forma, o inverso: ação política deliberada, às vezes, não consegue promover mudança social. Essa dicotomia é importante para apontar que, numa democracia constitucional, o jogo da separação de poderes envolve tanto ação quanto omissão. Da mesma maneira, o diálogo inter-institucional: pode-se deferir, esperar, decidir o mínimo possível, desafiar o outro poder a decidir novamente sob novo argumento, omitir-se para esquivar-se dos custos políticos etc. Todas esses comportamentos integram a competição política. Este código será importante para entender a posição flexível dessa tese quanto à atuação legítima da corte.

A oitava decorre da distinção entre o ordinário e o extraordinário, entre o cotidiano e o excepcional, ou mesmo entre o inferior e o superior na política. Nas palavras de Bruce Ackerman, entre a "política normal" e a "política constitucional", critério principal para que ele justifique o papel da revisão judicial nos EUA. ${ }^{67} \mathrm{~A}$ dicotomia denota não apenas dois níveis de elaboração jurídica ordenados hierarquicamente, ${ }^{68}$ mas também o simbolismo e a solenidade do nível constitucional,

\footnotetext{
${ }^{63}$ Um desdobramento dessas duas últimas dicotomias (entre última palavra e diálogo, e entre curto prazo e longo prazo) poderia explorar também a relação da democracia com a dimensão intergeracional. Essa dimensão destaca o nexo entre, de um lado, a geração presente e, de outro, a geração passada e a geração futura. Em que medida essas distinções entram no conceito de "povo" é relevante para a teoria democrática. Cf. nota de rodapé *n. 38 acima.

${ }^{64}$ Tema importante também na filosofia moral.

${ }^{65}$ A dicotomia entre esquerda e direita se associa, numa de suas acepções mais comuns, à conservação e mudança.

${ }^{66}$ Interessante a análise que Cass Sunstein faz da falsa neutralidade do status quo, pretexto usado, segundo ele, pela Suprema Corte americana para adotar uma determinada estratégia interpretativa (Cf. The Partial Constitution)

67 "Storrs Lectures: Discovering the Constitution".

${ }^{68}$ Isso é operacionalizado, na maioria das vezes, por meio de um procedimento mais dificultoso de reforma da constituição em relação a uma lei ordinária. A existência da revisão judicial é também tida como outra conseqüência lógica da superioridade da constituição, apesar de ambas opções procedimentais não serem essenciais à idéia de superioridade normativa da constituição (apesar de poderem ser um instrumento útil como estratégia de efetivação), como já argumentei em outros pontos deste texto e da dissertação.
} 
ao qual é reservado um status privilegiado. Seriam duas temperaturas e duas dignidades políticas diferentes. Um conecta-se à administração de rotina, o outro às grandes mudanças de rumo. Este "dualismo", juntamente com separação de poderes e carta de direitos, é tido como elemento fundamental do constitucionalismo. ${ }^{69}$ Uma adaptação dessa dicotomia destaca a diferença entre "casos de alta saliência política" e "casos de baixa saliência política", independentemente de serem processados formalmente pela política normal ou constitucional. Essa perspectiva substantiva é útil para que alguns autores de "teorias do diálogo" demonstrem que, ao menos em casos de alta saliência, a corte não decide livre de constrangimentos. ${ }^{70}$

A nona divide duas faces clássicas da legitimação do poder na filosofia política, uma baseada na igualdade ou no simples pertencimento a uma comunidade, outra baseada no conhecimento. Mais diretamente, seria o contraste entre "populismo" e "expertocracia". ${ }^{71}$ Com o aumento da complexidade das funções estatais, esse balanceamento torna-se ainda mais imperativo dentro de uma teoria normativa da separação de poderes. Argumentos pela revisão judicial, freqüentemente, assumem algum grau de expertise no papel dos juízes, treinados para decidir de uma certa maneira, supostamente mais sensíveis (ou em melhores condições deliberativas) para questões de princípios. Algumas teorias do diálogo também mostram que a justificativa do parlamento não é somente "populista", mas também tem relação com sua capacidade decisória específica, que não exclui, mas se complementa à das cortes. Dessa tensão se extraem objeções contra a revisão judicial baseadas nas idéias de paternalismo ou de regime de guardiões.

A décima, também obrigatória nos argumentos tradicionais em favor da revisão judicial, ocorre entre maioria e minoria. Parlamentos seriam o espaço de expressão da maioria e cortes constitucionais o local de proteção das minorias. Supõese, nesse caso (e a ciência política empírica relativiza em diferentes graus essa suposição), que a sociedade possa ser dividida nesses termos.

\footnotetext{
${ }^{69}$ Essa oscilação entre "ordinário" e "extraordinário" não ocorre, institucionalmente, apenas entre lei e emenda constitucional, mas também em rupturas, revoluções e refundações constitucionais. A qualidade desse momento de origem e inauguração gera muitas implicações para a teoria democrática (como em autores que desenvolvem o argumento do "pré-comprometimento", que veremos no cap 2).

${ }^{70}$ Conforme veremos no capítulo 4, Barry Friedman é o autor que lança luzes sobre essa distinção.

${ }^{71}$ Esses termos exatos foram usados por Christopher Zurn. (Cf. Deliberative Democracy and the Institutions of Judicial Review, p. 82)
} 
A décima primeira, bastante freqüente, põe lado a lado as diferentes perspectivas decisórias em que atuam parlamentos e cortes. Estas teriam o benefício do caso concreto, do exame retroativo e bem informado, a percepção dos impactos reais gerados pela lei. Aqueles estariam na dimensão menos palpável da especulação prospectiva e abstrata. De um lado, a particularidade do caso concreto. De outro, a universalidade da pretensão legislativa. Ambos os prismas se complementam, e a ausência da revisão judicial seria uma perda desse ponto de vista decisório. ${ }^{72}$

A décima segunda refere-se a dois tipos de ação coletiva envolvidos na democracia: a estatística e a comunal, nos termos de Dworkin, ou a agregativa e a deliberativa, nos termos de Zurn. Ao sustentarem que "contar cabeças" ou "agregar interesses formados numa esfera pré-política" (geralmente formados numa esfera prépolítica) não pode esgotar as formas desejáveis de o regime democrático tomar decisões, por incompatibilidade com seus valores subjacentes, defendem que uma corte pode se acomodar a esse arranjo se contribuir para a qualidade deliberativa (que pressupõe a capacidade de transformar preferências por meio do argumento). ${ }^{73}$ Esses dois tipos decisórios estariam também associados, respectivamente, à parcialidade e à imparcialidade potencialmente presentes em cada situação, ou à realização da preferência pessoal e à busca desinteressada pelo interesse público.

\footnotetext{
${ }^{72}$ Wil Waluchow tem nessa oposição uma das principais justificativas para a revisão judicial: de um lado uma corte que decide de modo incremental, caso a caso, de baixo para cima (bottom up), que seria a metodologia típica do common law. De outro, um parlamento que decide de cima para baixo, desprovido de um caso concreto. (Cf. A Common Law Theory of Judicial Review)

${ }^{73}$ Christopher Zurn, Deliberative Democracy and the Institutions of Judicial Review, cap. 2. Ronald Dworkin, "Constitutionalism and Democracy", p. 2, e Freedom's Law, "Introduction".
} 
Para terminar essa cansativa (mesmo que não exaustiva) lista, ${ }^{74}$ incluiria duas oposições que abriram o capítulo: a entre democracia e constitucionalismo, e a entre políticas públicas e direitos fundamentais, distinção central do liberalismo político. ${ }^{75}$ Categorizar e hierarquizar tipos de argumentos e tipos de decisão a partir de uma ordem de prioridades léxicas é um recurso da razão prática para solucionar dilemas decisórios sem grandes custos deliberativos. Uma vez admitida essa ordem de prioridades, o dilema está resolvido sem necessidade de engajar-se na avaliação das razões de cada lado. ${ }^{76}$ A caracterização de direitos como "trunfos", por exemplo, é uma tentativa de priorizar um determinado tipo de valor quando em conflito com outro.

A distinção entre políticas e princípios, especificamente, conforme vimos em Dworkin, tentou resolver as dúvidas sobre a divisão de trabalho entre legislador e judiciário na democracia. A linguagem dos direitos teria trazido para a moralidade política um recurso de proteção do indivíduo, uma pré-condição à legitimidade do "governo do povo". Por trás da política pública estaria um mero interesse individual. Do ponto de vista teórico (e também simbólico e da retórica política), é diferente ter um interesse e ter um direito. Mais do que isso, ter um direito implica num deslocamento institucional.

\subsection{Palavras, conceitos e retórica na política: sobre o título da tese}

\footnotetext{
${ }^{74}$ Vale mencionar algumas outras bastante presentes no direito e na política. No direito, por exemplo, as dicotomias entre positivismo e direito natural (decorrente de como se articula direito e moral); entre modos de interpretação mais "legalistas" e mais "criativos" (há uma enorme multiplicidade de termos opostos para denotar essa idéia: Ely popularizou-a por meio da oposição entre "interpretativistas" e "não interpretativistas"; em outras ocasiões, para demarcar o espaço das cortes e o espaço da política eleitoral, traduz-se também a mesma idéia pelo contraste entre a aplicação e a criação do direito); entre "casos fáceis" e "casos difíceis", sendo estes os que despertam as grandes divergências nas teorias da interpretação, pois correspondem aos momentos em que a norma não é suficiente para constranger o juiz; entre teorias jurídicas que concebem o direito "de cima para baixo" (top down), com base na sanção, ou "de baixo para cima" (bottom up), com base na adesão social, para referir-se ao contraste entre os positivismos de John Austin e Herbert Hart, respectivamente; entre common law e civil law. Na política, por sua vez, há uma série de jogos binários, para além dos já citados no texto, que costumam servir como chaves de leitura e classificação de tradições do pensamento político: atomismo e holismo; indivíduo e comunidade; esfera privada e esfera pública; sociedade civil e estado; natureza humana egoísta e auto-interassada ou virtuosa etc.

${ }^{75}$ Distinção que Dworkin chamou de "princípios" e "policies", para delimitar o espaço da autonomia individual, e o espaço do bem comum entendido na sua acepção utilitarista (bem-estar geral como função da maximização do bem-estar do maior número possível de indivíduos).

${ }^{76}$ Trata-se do que Joseph Raz chamou de "razão excludente" (exclusionary reason) para explicar a especificidade do direito diante de outras considerações morais; do que Dworkin chamou de "trunfo" para justificar a prevalência de direitos sobre considerações de bem-estar geral; e do que Rawls chamou de prioridade léxica para ordenar princípios de justiça.
} 
As observações a respeito da postura gradualista e as dicotomias-chave que orientam parte substancial da teoria política são convidativas para alguns breves desdobramentos sobre o uso do vocabulário político. Não pretendo, aqui, entrar no amplo campo de investigação sobre a linguagem no domínio da política, mas apenas estabelecer premissas que explicam a maneira como a tese pretende lidar com as palavras mais recorrentes desse debate e como escolhi o título da tese. ${ }^{77}$

Os conceitos e palavras que integram o vocabulário político passaram por um percurso histórico conflituoso. Em cada momento, propiciaram uma forma de conceber e entender o espaço da política, de descrever tipos de organização política (em comparação com outros), e de imaginar ou prescrever padrões de legitimidade, modelos de boa forma de governo. Orientam, portanto, diferentes olhares sobre um objeto também em constante mutação.

Estabilidade não é uma qualidade desse vocabulário. Provavelmente, devido a uma pluralidade de motivos. Um deles é o fato da "contestabilidade essencial" da maior parte dos conceitos políticos, para voltar a uma observação do tópico anterior. ${ }^{78}$ A sua ambigüidade e imprecisão, nesse sentido, não são um estado efêmero a ser superado por maior esforço de análise racional, mas de sua própria natureza. Isto é, tais palavras despertam desacordos razoáveis sobre o seu significado correto, e tal desacordo é insanável. Às vezes, diferentes palavras referem-se a conceitos bastante semelhantes, ou mesmo a realidades similares, difíceis de discernir com nitidez. ${ }^{79}$

Outra conseqüência de tal caráter "essencialmente contestado" é que tais termos não são apenas instrumentos neutros da comunicação e da luta políticas, não

\footnotetext{
${ }^{77}$ A discussão sobre o papel da linguagem no estudo e no exercício da política desenvolveu-se especialmente no século XX, influenciado pelo movimento da "filosofia da linguagem ordinária" (provocado por Wittgenstein e J. Austin). Dois livros interessantes sobre o assunto seriam: Ball et. al. Political Innovation and Conceptual Change; e Pocock et al.. Conceptual Change and the Constitution. Autores clássicos também não deixaram de perceber a dimensão verbal da política. Waldron, p. ex., mostra isso em relação a Bentham e Hobbes: "Like an earlier English philosopher, Thomas Hobbes, Bentham was convinced that one of the main sources of conflict in politics was verbal vagueness, equivocality and confusion". (Nonsense Upon Stilts, p. 34)

${ }^{78}$ Alasdair MacIntyre, inspirando-se na idéia de "conceitos essencialmente contestados" de Gallie, comparou algumas características dos conceitos das ciências naturais e sociais. "The Essential Contestability of Some Social Concepts", p. 1-9.

${ }^{79}$ Cf., p. ex., Cícero de Araújo sobre a distinção entre "estado" e "república" na história do pensamento e das instituições políticas. (Fundações da República e do Estado)
} 
causam simplesmente tais "desacordos razoáveis". São também, com freqüencia, alvos dessa própria luta. Estão no calor da política, não num ambiente asséptico e impermeável. São objeto de manipulação ideológica e estratégica por meio de manobras lingüísticas que estruturam o debate público de modo enviesado. ${ }^{80}$ Servem como slogans ou como expressões de efeito para conquistar adesão dentro de um projeto de ação ou de teorização política. ${ }^{81}$

A linguagem que usamos, portanto, influencia os tipos de reação e desperta sensibilidades diversas. Em nome de que criticamos ou defendemos um determinado arranjo de poderes, uma certa política pública, uma dada interpretação constitucional? Quando estamos autorizados a utilizar certos termos? Há propriedade intelectual sobre conceitos políticos? Certamente não há resposta incontroversa para essas perguntas. Tais conceitos se descolam de sua origem histórica e evoluem de forma pouco previsível, ganham novos usos e passam a aplicar-se a diferentes contextos. ${ }^{82}$

De uma lista dos termos mais usados e abusados na história moderna, sem dúvida não poderia faltar: "democracia" e "constituição" para a boa forma de governo, "liberdade" (ou "direitos", opção mais abrangente e mais enraizada hoje em dia) para o respeito ao indivíduo, "igualdade" para a justiça social, "desobediência civil" para o protesto político legítimo, entre outros. Rótulos servem também para dividir e classificar agremiações teóricas: liberais, utilitaristas, comunitaristas, republicanistas, marxistas etc. ${ }^{83}$ Essa classificação facilita a simplificação do confronto e, às vezes, ao enfatizar o conflito e as diferenças, perde de vista os pontos em que concordam. Escolas de pensamento tornam-se excludentes e adversárias, sem perceber que às vezes compartilham de muitas posições, seja no nível dos princípios,

\footnotetext{
${ }^{80}$ George Lakoff mostra, por exemplo, como o debate sobre aborto nos EUA foi estrategicamente estruturado em torno das categorias "pro-life" e "pro-choice" (polarização conveniente para aqueles que se posicionam do lado "pro-life"), entre outras metáforas que impactam o nosso processo cognitivo em diversas áreas, a política entre elas. ( Cf. Metaphors We Live By).

${ }^{81}$ Esse fenômeno se manifesta de maneira curiosa, por exemplo, na prática de "batismo" de partidos políticos. No Brasil, o repertório de ideais políticos contidos nos nomes de cada partido é numeroso.

${ }^{82}$ Neil Walker, por exemplo, na palestra "Europe's Midlife Crisis", proferida na Universidade de Edimburgo em 22 de novembro de 2007, discutiu a tentativa de a União Européia caminhar para o "registro constitucional" e lançou a provocação: "Há um comissário do conceito de constituição?" Num momento em que a esfera supra-nacional tem sido o principal campo de inovação institucional, tornouse fértil a reflexão sobre a transposição de conceitos típicos do estado nacional.

${ }^{83}$ Quem fornece a versão mais desejável da igualdade, marxistas ou liberais? Essa pergunta orienta parte do esforço recente de Gerald Cohen (If You're an Egalitarian, How Come You're so Rich?) e exemplifica o debate sobre o que está efetivamente em jogo entre os diferentes rótulos classificatórios do pensamento político.
} 
seja no nível das soluções concretas; sem notar que podem se complementar e se enriquecer reciprocamente. ${ }^{84}$

Preferências vocabulares, portanto, oscilam historicamente. Esse processo é determinado mais por uma dinâmica política do que por um gradual refinamento estritamente intelectual. A depender do clima ideológico, alguns termos caem em desuso e vão para a periferia de nosso vocabulário. Outros recebem novo colorido e alçam posições na escala de popularidade.

A divisão disciplinar entre, de um lado, teoria ou filosofia política, e, de outro, ciência política, ocorrida no século $\mathrm{XX},{ }^{85}$ também tem uma dimensão lingüística interessante. A segunda, na tentativa de conquistar respeitabilidade científica, deixou com a primeira as especulações normativas e os juízos morais, e tentou olhar para a política tal como ela efetivamente funciona. Para tanto, tentou neutralizar o vocabulário e utilizá-lo com propósito meramente descritivo. Naturalizou o ponto de partida. Supôs, assim, que possamos nos dirigir ao "mundo real" sem uma série de conceitos normativamente definidos, que possamos acessá-lo de forma isenta, sem escolhas valorativas prévias, ou que o descritivo e o normativo são duas formas independentes de investigação. ${ }^{86}$

Há um exemplo oportuno e elucidativo sobre isso: "democracia" é uma categoria com imenso apelo simbólico, conforme observado no tópico anterior, e costuma ter a qualidade de trunfo na escala de razões da argumentação prática. É, sabidamente, escorregadia, não só porque pode ser usada retoricamente, mas também porque possui muitos sentidos. ${ }^{87}$ É aplicada com pretensão, por vezes, normativa (para

\footnotetext{
${ }^{84}$ Dois exemplos interessantes sobre como reduzir desacordo no nível dos princípios quando não houver perspectiva de acordo no nível concreto, e vice-versa, são oferecidos, respectivamente, por Dennis Thompson e Amy Gutman (Deliberative Democracy) e por Cass Sunstein ("Constitutional Agreements Without Constitutional Theories").

${ }^{85}$ Cf. Sheldon Wolin, "Political Theory as a Vocation", e John Gunnell, Between Philosophy and Politics: The Alienation of Political Theory.

${ }^{86}$ Alasdair MacIntyre, em "The Essential Contestability of Some Social Concepts", mostra como, por ser social o nosso objeto de estudo, essa separação é falaciosa. Há muitos outros autores que também discutem essa tentativa de uma descrição neutra de um fenômeno social, na posição de um observador externo, que não é necessariamente participante dessa mesma atividade. Parte do debate entre Herbert Hart (e vários discípulos), de um lado, e principalmente Lon Fuller, Ronald Dworkin e John Finnis, de outro, sobre como melhor entender e explicar o "direito", é exatamente sobre essa que ficou conhecida como a "questão metodológica" na teoria jurídica.

${ }^{87}$ Robert Palmer faz levantamento didático sobre e evolução do termo "democracia", seu papel enquanto símbolo político na Revolução Francesa e os predicados que o termo adquiriu recentemente
} 
imaginar o "melhor regime"), por outras, descritiva (para separar os países “democráticos" dos "não-democráticos"). ${ }^{88}$ John Dunn notou que essa confusão tem gerado, na história recente, uma "espúria validação normativa" 89 dos atos cometidos por regimes tidos como democráticos. Em vez de iluminar, a categoria "democrático" teria ofuscado e prejudicado nossa capacidade de julgar a qualidade de ações políticas concretas. Por seu valioso "status presumido",90, foi vítima de um uso promíscuo e diversionista e produziu um efeito mistificador e entorpecente.

Essas observações servem para introduzir e dar a dimensão do problema da escolha das palavras quando participamos da política, seja como ativista, seja como teórico. Uma opção é usar as que já integram a tradição. Dentro da tradição, alguns termos são catalisadores e promotores do consenso, com maior poder aglutinador. Alguns expressam apelo normativo mais acentuado, outros têm menor voltagem ideológica. Trazem uma longa história. Outra opção é inventar um novo repertório terminológico e marcar novas posições em relação à tal tradição. A tese, como já foi possível perceber, opta obviamente pela primeira, e tenta tomar as devidas cautelas que tal escolha recomenda.

Em primeiro lugar, no título: "Direitos fundamentais, separação de poderes e deliberação". A tese não é uma empreitada de análise conceitual pura, de genealogia de uma idéia, de rastreamento das suas origens e evolução ou algo parecido. Trata-se de um exercício de argumentação sobre um problema normativo já enfrentado no mestrado. Lido, novamente, com alguns ideais políticos (e os termos correspondentes) e com práticas institucionais que se colaram historicamente a eles. Poderia adotar, portanto, o mesmo título do trabalho que a antecede, pois democracia e constitucionalismo continuam a ser, necessariamente, o pano de fundo.

Adoto um novo título, entretanto, não por eventual necessidade de diferenciação com o trabalho anterior, mas para lançar luzes em aspecto diferente do

no discurso político, a partir da I Guerra Mundial: é um símbolo freqüente de valores políticos, com um sentido sempre favorável e emocionalmente inspirador. "Notes on the Use of the Word 'Democracy': 1789-1799", p. 203.

${ }^{88}$ Robert Dahl preferiu criar um novo termo para referir-se aos regimes existentes e assim distinguiu a poliarquia da democracia. (Cf. Democracy and Its Critics)

${ }_{89}^{80 h n}$ Dunn, "Disambiguating Democracy".

${ }^{90}$ Ibid. 
mesmo problema, redirecionando as ênfases. O título compõe-se de três expressões. As duas primeiras correspondem ao desdobramento convencional do constitucionalismo: uma determinada estratégia procedimental de diluir o poder, de modo que ele se autocontrole, e uma dada lista de limites substantivos às suas decisões. Espelham a tensão entre procedimento e substância na limitação do poder. O terceiro elemento sugere um critério para orientar a relação entre os dois primeiros. Dito de outra maneira, o título opta por apontar mais diretamente para os três componentes da abordagem adotada: direitos fundamentais como requisito de justiça política que deve permear parte do processo decisório dos três poderes, e a deliberação como qualificador dessa interação e medida para avaliar a legitimidade de suas decisões.

Ao relacionar os direitos fundamentais com a separação de poderes, destaco a cooperação institucional necessária para a sua promoção, em vez de colocá-los sob o prisma convencional do judiciário como "última trincheira" na proteção dos direitos ameaçados pelos outros poderes. Altera-se o registro e discute-se a implementação dos direitos em diferentes níveis e estágios dentro dos três poderes, não somente a sua heróica defesa judicial.

Reconheço, contudo, que continuo a me concentrar na relação específica entre parlamento representativo e corte constitucional. Para que se justifique o uso do termo geral "separação de poderes", suponho que haja um princípio subjacente que transcende àquela relação bilateral específica. Mais especificamente, as idéias de diálogo e de relativização da última palavra. Na escolha dos termos, portanto, o título tenta "esfriar" e reduzir a voltagem ideológica em relação ao uso de "democracia". No decorrer da tese, será inevitável voltar a lidar com aqueles outros termos omitidos no título.

Abri este tópico de digressões metodológicas prometendo a exposição de alguns princípios de trabalho. Destaquei o papel que na análise teórica da revisão judicial pode ter uma postura: aberta e sensível às suposições e implicações envolvidas, ajudando leitor e autor a situar-se dentro da cadeia argumentativa da teoria política; cuidadosa para lidar com a literatura norte-americana e isolar as variáveis institucionais; gradualista para escapar das armadilhas binárias presentes nas 
várias dicotomias que perpassam o texto; e atenta aos usos e abusos das palavras em nome de ideais políticos. São metas exigentes que a tese procurará atender. É pouco provável que seja bem sucedida em todas elas, mas acredito serem medidas consistentes, entre outras possíveis, para avaliar a qualidade do produto final.

\section{Quem decide o que e como e quando e por que numa democracia?}

A pergunta tenta clarear as dimensões várias e interdependentes da tomada de decisões coletivas. Ela ajuda a estruturar uma análise abrangente de como uma democracia organizada sob o princípio dos freios e contrapesos (ou mesmo outro tipo de regime) precisa lidar com cada um desses elementos para regular seu modo de promover escolhas vinculantes sobre toda a comunidade. Devido à generalidade e à maleabilidade dessa formulação, a pergunta provavelmente encobre tudo o que está em jogo na justiça procedimental - o processo mais legítimo de resolver demandas coletivas.

Quem decide? O ponto de partida intuitivo para investigar a natureza de um regime político é buscar pelo ator político central, ou a fonte de onde emergem os comandos jurídicos e políticos. Saber a quem pertence a autoria das decisões coletivas dá a impressão de ser a única pergunta com a qual realmente vale a pena se preocupar. ${ }^{91}$ Numa monarquia absoluta, por exemplo, tudo que se necessita saber, ou pelo menos a informação mais relevante, é: “quem é o monarca?”. As outras respostas seriam diretamente deduzidas: Quando? Sempre. O quê? Tudo. Como? Pela vontade do monarca. Por quê? Porque ele é o monarca.

Alguém poderia argumentar que, numa democracia, a resposta seria muito similar, bastando substituir o monarca pelo "povo". Mas isso explicaria muito pouco, ignoraria a dificuldade do conceito de "povo" e não apreenderia precisamente como democracias constitucionais foram historicamente organizadas. ${ }^{92}$ Quem decide, ou,

\footnotetext{
${ }^{91}$ O pensamento clássico grego classifica as formas simples de governo identificando "quem" por um critério numérico: governo de um, de alguns e de muitos. Da combinação dessa forma simples decorreriam constituições mistas (Cf. Cícero de Araújo, Fundações da República e do Estado, cap. 1).

${ }^{92}$ Mesmo porque, é bom lembrar, os regimes políticos modernos não abrem mão de algum grau de expertise no desenho de suas instituições. O "quem decide", nesse sentido, exige especificações sobre as qualidades do agente indicado. Para algumas decisões, basta ser membro da comunidade, cidadão.
} 
simplesmente, quem é o soberano, não é suficiente para entender esses regimes devido à multiplicidade de atores que impactam substancialmente o processo de tomada de decisões coletivas em nome do povo. ${ }^{93}$ Assim, a autoridade legítima, nesse contexto, é definida num sentido composto, dependendo do tipo, procedimento, tempo e justificação da decisão. ${ }^{94}$ Não há espaço para uma resposta monolítica e unidirecional.

Além disso, se mudamos o verbo e em vez de "quem decide" perguntamos "quem obedece", veríamos que a democracia constitucional apresenta um nó ainda mais enredado: o produtor de normas se sobrepõe, supostamente, ao seguidor de normas. ${ }^{95} \mathrm{O}$ auto-governo popular, dessa maneira, significa que "o povo" decide que normas "o povo" terá que obedecer e quais objetivos comuns perseguirá. O detentor do poder e o destinatário do poder, com óbvias qualificações, coincidem. ${ }^{96}{ }^{97}$

Para outras, basta ter sido eleito ou escolhido por outro processo. Para outras, ainda, é necessário ter alguma qualificação especial para compor uma estrutura burocrática técnica.

${ }^{93}$ Tais atores politicos, aqui, podem ser entendidos não apenas como autoridades estatais formais, mas também como fontes informais que influenciam a decisão política, que ecoam as preferências da comunidade e, em alguma medida, são capazes de agência política. As ramificações do conceito de democracia como "governo do povo, pelo povo e para o povo" (oriunda de frase famosa de um discurso de Abraham Lincoln) poderia sofisticar mais essa análise.

${ }^{94}$ Paul Brest formulou de modo mais claro a importância de saber quem tem a autoridade para interpretar a constituição: "Hermeneutics has nothing to say about this question. But its recognition that interpretation is inevitably affected by the interpreter's experiences and interests makes it important to continue to ask how the allocation of constitutional decision-making authority might be made consistent with our commitment to democracy". Paul Brest, "Who Decides?", Southern California Law Review, v. 58, p. 671 (1985). Waldron também elucida esse problema ao mostrar, por meio de um argumento de Hobbes, que a legitimidade institucional depende do procedimento formal (da localização da autoridade), não da justiça da decisão. Já que as pessoas discordam sobre justiça, se essa fosse uma condição para obediência, haveria um risco de anomia e desobediência generalizada, ao sabor do capricho (ou mesmo da deliberação sincera) de cada indivíduo. A preocupação com a autoridade, mais do que com a resposta certa sobre a sociedade justa, é a convocação teórica que Waldron promove por meio de seus livros Law and Disagreement e The Dignity of Legislation, além de vários artigos.

${ }^{95}$ Suponho aqui que a democracia não pode abrir mão de normas como um instrumento para governar o comportamento humano. Nesse sentido, qualquer acepção concebível de democracia (ou qualquer tipo de governo), precisa supor que é possível, de alguma maneira, regular o comportamento humano por meio de regras gerais politicamente produzidas.

${ }^{96}$ Essa afirmação certamente tangencia algumas importantes questões da teoria democrática: Pode uma comunidade ser democrática sem um governo democrático, ou um governo democrático existir sem uma sociedade democrática? Uma comunidade democrática precede o governo democrático, assim como os seguidores de normas (norm-users) precedem os produtores de normas (norm-givers)? (v. MacCormick, Institutions of Law). A abordagem clássica da relação entre sociedade democrática e governo democrático é Democracy in America de Tocqueville. A literatura que estuda a relação entre desenvolvimento econômico e desenvolvimento político descreve também o processo histórico de vários países que se tornaram democráticos à medida em que cresceram economicamente. (Cf. Przeworski et al. Democracy and Development)

${ }^{97}$ Paul Kahn também já discutiu a relação entre o produtor de normas (ruler) e o destinatário de normas (rule-follower) na democracia: "The discourse of constitutional theory has in large measure been a conversation about the self of self-government. If the divergence about the self and self-government is too great, then the constitutional system loses its appearance of legitimacy. It would be a mistake, 
Decide o quê? Esse elemento demarca o campo da política, a dizer, os assuntos objeto de preocupação de toda a comunidade e aqueles reservados à vida extra-política, ou, para uma certa tradição, à vida privada. A fronteira até a qual se permite que a decisão política legítima avance oscilou durante a história política e do pensamento. ${ }^{98}$ Esse trabalho, contudo, adotará a distinção básica fornecida pelo liberalismo político entre direitos (rights) e políticas públicas (policies). Adoto essa distinção para me concentrar exclusivamente nas decisões relativas a direitos, ${ }^{99}$ já que é dentro desse campo conceitual que as questões controversas sobre o mínimo de justiça substantiva esperado da democracia e a legitimidade do controle de constitucionalidade emergem. A política, em outras palavras, tem um escopo muito maior do que a definição do domínio dos direitos. Este, entretanto, é o ponto focal da tensão de legitimidade entre parlamentos e cortes dentro das democracias constitucionais.

Decide como? Esta pergunta designa os passos exigidos para a tomada de uma decisão válida e legítima. Preocupa-se com a justiça do procedimento que os membros de uma comunidade escolheram para decidir suas questões comuns. Como já dito, a legitimidade de uma decisão numa democracia constitucional é mensurada tanto por seu conteúdo (output) quanto pelo seu procedimento (input). Em relação a questões que provocam um grau acentuado de desacordo, como geralmente acontece com os conflitos de direitos, a dimensão procedimental se impõe de modo ainda mais impactante como umas das escolhas cruciais a serem feitas. O reconhecimento de um procedimento justo estimula a aquiescência em face de resultados não consensuais.

A primeira escolha procedimental feita por esses regimes, como vimos, foi diluir o poder de modo que, por meio dos freios e contrapesos, violações arbitrárias de direitos fosse previnidas. Mas há passos adicionais no centro do problema aqui investigado, e que vão além de simplesmente dividir o poder. A segunda escolha procedimental, num nível suplementar, foi decidir a base sobre a qual cada poder

however, to assume that government has been measured against a stable concept of the self. The selfidentity of the citizen has been as much the product as the starting point of this conversation". (Legitimacy and History, p. 3)

${ }^{98}$ Wolin, Sheldon. Politics and Vision, p. 6-9.

99 *O que John Rawls chamou de “constitutional essentials". (Cf. Political Liberalism, p. xx). 
operaria. Parlamentos, de acordo com a descrição convencional, são responsáveis por institucionalizar a regra de maioria e a representação eleitoral do povo. ${ }^{100}$ Cortes, por sua vez, são insuladas da política eleitoral para que tenham condições ideais de imparcialidade para decidir sobre direitos, os quais não podem, por definição, estar sujeitos ao tipo majoritário de justificação. ${ }^{101}$ Espera-se também que dentro de cortes as decisões sejam inspiradas, primeiramente, pelo argumento e pela deliberação, enquanto parlamentos estão mais sujeitos à barganha, à agregação de preferências e ao voto, já que esse local decisório seria mais refratário à deliberação. Não teria sido desenhada para tanto nem incentivaria postura desconectada com interesses mais imediatos de eleitores ou do próprio parlamentar. ${ }^{102}$

Para além dessas considerações de puros inputs procedimentais, a dimensão do "como" também tangencia as qualidades formais de diferentes outputs que cortes e parlamentos produzem. Cortes tomam decisões que possuem uma racionalidade incremental, tanto prospectiva quanto retrospectiva, em oposição à legislação, que usualmente traduz-se numa regra geral, abstrata e prospectiva. Independentemente do conteúdo do output, portanto, suas qualidades formais são inerentes ao desenho procedimental dessas instituições. ${ }^{103}$

Decide quando? A dimensão temporal da política pode também ser dividida entre uma questão de output (os efeitos temporais da decisão - retrospectiva, prospectiva ou ambas) e uma questão de input - o momento adequado para decidir. Vou me concentrar nessa segunda dimensão porque ela aponta para outras

\footnotetext{
100 Tenho consciência de que essa concepção de parlamentos e cortes e suas respectivas fundamentações normativas dizem respeito, grosso modo, a como essas instituições foram recebidas e reinventadas pelas democracias constitucionais modernas. Historicamente, ambas as instituições têm origens e lógicas muito distintas dessa tradução moderna, e passam longe da preocupação da representação do povo, por um lado, e da proteção de direitos individuais, do outro. Sobre a relação entre parlamento e democracia, p. ex., cf. Bernard Manin, The Principles of Representative Government.

${ }^{101}$ Cortes são instituições colegiadas e, mesmo que grande ênfase seja posta na deliberação e na argumentação, quando o desacordo persiste, também decidem por regra de maioria. Entretanto, diferentes cortes constitucionais implementam diferentes modelos de "fóruns deliberativos", variando, de um lado, entre aquelas que promovem deliberações secretas e se expressam publicamente por meio de uma voz única e consensual (como a francesa e, geralmente, a alemã), até as que fazem o desacordo externo mais explícito, publicam votos vencidos e cujos juízes se comportam de modo majoritário (como a brasileira). (Cf. Pasquino e Ferejohn, "Deliberative Institutions")

${ }^{102}$ Cortes se defrontam com uma "expectativa deliberativa" mais exigente, já que sua autoridade não é baseada na representação eleitoral e na prestação de contas (accountability).

${ }^{103}$ Sobre as qualidades formais da legislação e os respectivos princípios da "moralidade interna do direito", ver Fuller em The Morality of Law.
} 
preocupações centrais subjacentes à divisão de poderes. Isso é crucial porque nenhum poder tem exclusividade para decidir questões de direitos, mas participam numa certa seqüência, num intrincado circuito decisório. Eles têm competências sobrepostas relativas a direitos, sobreposição que se resolve pela determinação do momento apropriado para cada um agir. Usualmente, nos momentos de "política normal", ${ }^{104}$ parlamentos têm o poder de iniciar e aprovar uma solução para um problema comum por meio de uma lei. Esta seria o ponto de partida para a inovação na ordem jurídica. Cortes, então, podem ser provocadas a rever a lei em termos de sua validade constitucional. São passivas e reativas. Esse circuito continua em estágios posteriores que variam de sistema para sistema.

A interação ao longo do tempo é o fenômeno a ser percebido aqui. Dependendo de cada constituição, haverá um nível decisório “último, porém provisório" (legislativo ou judicial), ${ }^{105}$ além do qual não há recurso institucional adicional, exceto pelo reinício do processo, numa nova rodada procedimental. O foco no "último nível" é destacado pelas teorias da última palavra. A percepção de uma inevitável e permanente circularidade, por outro lado, decorre de uma sensibilidade temporal mais sofisticada das teorias do diálogo. O prisma temporal insere um regime político numa perspectiva diacrônica e ajuda a enxergá-lo como um empreendimento infinito de longo prazo, não apenas um conjunto de "momentos decisórios" isolados do soberano.

Finalmente, decide por quê? Democracias constitucionais clamam legitimidade com base na justificação por trás das decisões coletivas, e especialmente por trás das decisões referentes a direitos, que requerem um tipo mais elaborado de argumentação moral. Direitos ocupam um lugar decisivo na moralidade política subjacente ao modo como a legitimidade democrática é pensada. "Decide por quê",

\footnotetext{
104 "Política normal" se refere às decisões ordinárias tomadas por autoridades estabelecidas e se opõem aos "momentos constitucionais", quando "o povo" toma decisões fundacionais sobre a constituição. (Cf. Bruce Ackerman, "The Storrs Lectures: Discovering the Constitution")

${ }^{105}$ Obviamente, há a possibilidade de revolução, que ocorre para além das instituições, rompendo-as. É importante também esclarecer a moldura institucional minima que o texto pressupõe quando discute o papel de parlamentos e cortes. Como dito na introdução, suponho apenas que os regimes em questão possuem uma constituição e uma carta de direitos somada a alguma prática de controle de constitucionalidade. Há outras variações adicionais que possuem impacto relevante na discussão (como, por exemplo, entre modelos fortes e fracos de revisão judicial). Meu nível de análise aqui, porém, possui um grau de generalidade que provavelmente faz esses argumentos serem aplicáveis, em alguma medida, a qualquer sistema de controle de constitucionalidade.
} 
nesse sentido, conecta-se a "por que devo obedecer". De onde vem a autoridade da legislação e das decisões judiciais? Quais são as exigências formais e substantivas para decisões sobre direitos e políticas públicas? A resposta varia conforme diferentes teorias políticas, e precisa conciliar os outros elementos da questão geral esboçada neste tópico. É uma combinação de razões procedimentais (input) e de razões substantivas (output): por um lado, razões que justificam por que um ator político decide alguma questão por meio de certo procedimento num determinado momento; por outro, razões que justificam o conteúdo da decisão em si.

Em resumo, essa moldura geral permite perceber que, em democracias constitucionais, a determinação de "quem" (parlamentos ou cortes) não basta, e tampouco é uma função do "que" (direitos ou políticas públicas), mas também uma função do "como", "quando" e "por que". A pergunta tenta dirigir-se para a complexidade de uma forma de governo que apresenta respostas plurais a cada demanda decisória. Uma decisão não é democrática em razão de um elemento isolado. Há muitos atores, categorias de decisões, procedimentos, "momentos decisórios" e justificações. Mesmo que as fronteiras analíticas entre essas cinco dimensões possam ser maleáveis e às vezes coincidentes, o mérito da questão é a exigência de uma abordagem teórica da separação de poderes que não ignore nenhuma das variáveis interdependentes da legitimidade.

Desenhar instituições é um exercício de balanceamento, de compensações, de trade-offs entre diversos valores que não se realizam por inteiro sem interferir em outro igualmente importante. Seja pelo sopesamento de princípios, seja pela análise mais crua de custo-benefício, deve-se encontrar algum ponto de equilíbrio entre os vários fatores. Este é um senso comum abstrato, insuficiente para resolver dilemas concretos por si só.

Uma comunidade que se governa democraticamente precisa ter costurado as variáveis presentes na pergunta-título mais ou menos explicitamente. Quanto mais explícito, porém, melhores as condições para entender e criticar sua operação. Para entender a separação de poderes na democracia, dessa maneira, é necessário dar conta de todas essas dimensões. Medir a legitimidade democrática, tanto de um regime 
político quanto de decisões coletivas isoladas, é também um exercício multi-facetado, que não pode prescindir de cada uma daqueles elementos. ${ }^{106}$

Já que restringi a investigação desse trabalho a direitos, a questão geral pode ser levemente reformulada: Quem e como e quando e por que decide sobre direitos numa democracia constitucional? Esse direcionamento ajuda a estruturar a análise e estabelecer os termos pelos quais as diferentes respostas das teorias da última palavra, sejam elas inclinadas por parlamentos, sejam por cortes, ou das teorias do diálogo podem ser postos.

Poder-se-ia notar alguma semelhança da pergunta-título com a forma pela qual Hart concebe o direito e o lugar central das regras secundárias (regras que atribuem poderes). Tais regras oferecem os remédios para os defeitos de regimes mais primitivos e pré-jurídicos, nos quais existem somente regras primárias (regras que impõem deveres). Três são os defeitos: a incerteza, a estaticidade e a ineficiência. Três são, respectivamente, os remédios: a regra de reconhecimento, a regra de mudança e a regra de adjudicação. Só existirá um sistema jurídico maduro quando se puder perceber que, pelo menos autoridades públicas e, se possível, a maioria dos cidadãos comuns aceitam tais regras secundárias. Num sistema jurídico em crise ou patológico, há algum grau de conflito em relação a quais são elas. Hart defende que está a observar um fato, não a emitir um juízo de valor. ${ }^{107}{ }^{108}$ Sua formulação certamente tangencia os componentes de "quem", "o que", "quando" e "como" da pergunta desse capítulo. A dimensão do "por quê" converte a pergunta, entretanto, em normativa. Hart não se propunha, em sua teoria do direito, a encontrar as melhores razões para a obediência, mas somente a constatar, entender e descrever um fato

\footnotetext{
${ }^{106}$ A pergunta se aplica tanto à "macro-escala" da escolha institucional quanto à "micro-escala" do desenho institucional, conforme definidas por Vermeule e Garrett: "Institutional choice asks which social tasks should be allocated to which institutions, holding the design of those institutions constant; institutional design asks what internal structure and decision rules institutions should have, holding the allocation of social tasks across institutions constant. Both institutional choice and institutional design are necessary components of normative constitutional analysis" ("Institutional Design of a Thayerian Congress", p. 1280). A tese, contudo, concentra-se somente no plano da escolha institucional (ainda é uma tese sobre Cortes contra Parlamentos)

${ }^{107}$ Cf. HLA Hart, The Concept of Law, p. 90-110.

${ }^{108}$ É curioso notar que Dworkin também faz uma distinção bastante semelhante à entre regras primárias e secundárias de Hart. Quando discute a inter-dependência dos ideais de democracia e constitucionalismo, Dworkin sustenta que regras constitucionais "habilitadoras" e "desabilitadoras" ("enabling" e "disabling constitutional rules") são pré-requisito, e portanto, limite, à democracia. (Cf. "Constitutionalism and Democracy", p. 2-3)
} 
social - o fenômeno jurídico. A pergunta desse capítulo busca estruturar analiticamente uma teoria normativa do desenho institucional e iluminar todas as demandas que uma tal teoria deve enfrentar.

\subsection{Estruturas do desacordo}

Conforme afirmei anteriormente, esse tópico tentaria "abrir um pouco mais a couraça" e inserir o tema de fundo da tese num quadro mais preciso. Quero mostrar, em outras palavras, os principais níveis analíticos (ou, ao menos, versões terminológicas) que o debate tangencia e perceber como cada um deles desperta diferentes graus de calor ideológico. O tópico anterior já cumpriu parte desse papel, ao formular uma pergunta que disciplina as respostas das teorias que vou estudar nos capítulos seguintes. Neste tópico, pretendo voltar a me referir a uma maneira mais tradicional de estruturar o problema. Ela aparece já no primeiro parágrafo do capítulo: subjacente ao conflito entre parlamentos e cortes há, pelo menos, uma articulação das tensões entre dois ideais políticos (democracia e constitucionalismo), dois tipos de decisão (direitos e políticas públicas) e duas demandas de legitimidade (procedimentais e substantivas). A dificuldade de entender as posições, portanto, não se limita ao número de argumentos favoráveis e contrários, mas decorre da variedade de níveis teóricos, suas intensidades e implicações institucionais.

O desacordo básico que orienta a classificação dos três próximos capítulos é institucional. Por essa via, encontrei três posições. Quem decide por último? Alguns defendem as cortes, outros os parlamentos e outros, ainda, dizem que "depende", que pode ser tanto um quanto outro, que eles interagem, que outras considerações são necessárias para determinar a legitimidade de cada instituição em cada momento. Mas no que mais as posições discordam? O que está por trás dessa divergência sobre preferência institucional? Esse desacordo se replica linearmente para outros níveis além do institucional?

Um exercício para encontrar suposições compartilhadas não diminuiria a importância do desacordo institucional, mas dimensionaria e localizaria o problema de maneira mais fidedigna. Perceberíamos que os adversários no campo institucional nem sempre discordam nos outros níveis, e encontraríamos o lugar em que eles se 
separam. Dentro de um esforço reconciliatório, essa distinção entre os níveis teóricos permitiria mostrar algumas camadas subterrâneas com potencial acordo por baixo do desacordo superficial.

Uma primeira tentativa de sistematização proporia a seguinte seqüência binária de equivalências:

\section{Ideais políticos \\ Variáveis de legitimidade \\ Decisões \\ Instituições}

\author{
I \\ Democracia \\ Forma \\ Políticas públicas \\ Parlamento
}

II

Constitucionalismo

Substância

Direitos

Corte

Recorrendo à extensa bateria de dicotomias enumeradas anteriormente, poderia ainda somar algumas que se adaptariam bem a essa lógica: maioria $v$. minoria, curto prazo $v$. longo prazo, populismo $v$. expertocracia, agregativo $v$. deliberativo. Talvez seja uma simplificação extrema reduzir qualquer teoria da revisão judicial a esses dilemas, mas tampouco seria errado dizer que poucas efetivamente se distanciam desse paralelismo estanque. O conflito, em parte significativa das "teorias da última palavra", estrutura-se dessa maneira, sem muito espaço para o meio-termo. Talvez fosse possível expandir ainda mais essa tabela de níveis de inferência, mas a raiz da tensão continuaria a ser parecida.

Um exame cuidadoso, contudo, revela alguns ruídos e cruzamentos que rompem a linearidade dessa estrutura. Desacordos institucionais nem sempre decorrem de concepções radicalmente distintas de democracia ou constitucionalismo. Não soa bem ao ouvido de alguns falar em demandas procedimentais e substantivas tanto de um quanto de outro ideal político. Suporiam que a democracia requer meramente um procedimento formal. A decisão é democrática se respeitar tal procedimento, independentemente da substância. O constitucionalismo, por sua vez, traria tanto uma demanda substantiva quanto procedimental ao exercício do poder (manifestadas, respectivamente, nos direitos e na separação de poderes). Outro modo comum de formular essa tensão é opor "democracia procedimental" e "democracia substantiva", ou vontade da maioria e direitos fundamentais (estes como précondições à legitimidade daquele procedimento). 
Essa operação, no entanto, envolve uma simplificação. Não é implausível suspeitar que a demanda pelo "governo do povo", assim como a exigência de limites, possuem parâmetros de legitimidade tanto substantivos quanto formais. Democracia, no sentido supostamente procedimental puro, seria entendida como um simples processo de decisão majoritária. Esse procedimento, contudo, tem que respeitar, ao menos, suas próprias condições de existência, a saber, a possibilidade de que maiorias e minorias co-existam numa comunidade e que considerem decisões coletivas como merecedoras de obediência. Isso não necessariamente sugere a possibilidade de uma agência externa ao legislativo para desempenhar o controle contra-majoritário. Tratase, simplesmente, de um requisito substantivo para que decisões majoritárias sejam concebíveis, e não um estratagema formal para encobrir decisões de ruptura do regime. ${ }^{109}$ Este regime tem que se auto-reproduzir, que sobreviver a si mesmo, que gerar um output que não suprima as condições do próprio input procedimental.

O constitucionalismo, por sua vez, requereria um procedimento de limitação do poder (freios e contrapesos) e um parâmetro substantivo para mensurar a legitimidade de decisões coletivas, geralmente corporificado numa declaração de direitos. Pareceria plausível defender que tais limites substantivos inerentes à "democracia procedimental" coincidem com os limites substantivos propostos pelo constitucionalismo (ou seja, direitos fundamentais). Seriam o mesmo objeto. De fato, talvez haja tal coincidência, dependendo de como cada autor e teoria concebe, define ou interpreta esses ideais.

A oposição entre democracia "meramente" procedimental, da qual decorreria a defesa da supremacia parlamentar, e democracia substantiva, concepção de alguns defensores da revisão judicial, nesse sentido, parece distorcer o que realmente está em questão. Autores considerados defensores de uma "democracia procedimental pura" dificilmente propõem que decisões majoritárias não possuem limites. Com mais freqüência, dizem apenas que tais limites não podem estar blindados numa carta de direitos interpretada exclusivamente pelo poder judiciário. Defendem que uma teoria sobre o melhor procedimento institucional é independente de uma teoria sobre os

\footnotetext{
${ }^{109}$ V. Waldron sobre a distinção de Arendt entre "decisão majoritária" e a "regra de maioria", The Dignity of Legislation, p. 186, nota de rodapé 9.
} 
melhores resultados possíveis, ainda que tal substância mínima continue a fazer parte de sua concepção de democracia. Recusam alguma presunção de infalibilidade ou mesmo de menor falibilidade. ${ }^{110}$ São céticos no plano institucional, mas nem sempre discordam nos outros níveis.

O que significam esses dois ideais políticos separados? ${ }^{111}$ Nos regimes políticos contemporâneos, passou a ser impossível fazer essa discriminação. Essa oposição conceitual geralmente perde o foco de qual é efetivamente a disputa. São termos com diferentes histórias e oriundos de diferentes tradições intelectuais, mas que foram se interpenetrando no momento de sua institucionalização. Quanto mais se sobe no nível de abstração da tabela esboçada acima, mais se perde clareza sobre o que está em disputa, propriamente, no nível institucional. O debate torna-se mais vulnerável à retórica e à luta apaixonada em nome de rótulos gradativamente esvaziados de significado, cujos conteúdos são estipulados de maneira muito diversa.

O nível dos ideais políticos é o mais sujeito a imprecisões e a generalizações que dificultam a verificação das implicações para os outros níveis. No plano das variáveis de legitimidade, o terreno fica um pouco mais claro, ou, ao menos, descarregado dos termos de alta voltagem política como "democracia". No das instituições, a visibilidade do problema torna-se mais imediata e concreta, mas precisa, claro, fazer suposições sobre os outros níveis. É especificamente esse passo argumentativo que costuma permanecer obscuro em grande parte da literatura, que subestima a necessidade de argumentos adicionais para justificar a derivação de um certo arranjo institucional a partir de um ideal. Não se trata de uma inferência automática, pois precisa atender ao ônus da prova sobre capacidades institucionais.

\footnotetext{
${ }^{110} \mathrm{O}$ que Waldron chamou, respectivamente, de "teoria de autoridade" e "teoria da justiça", duas tarefas complementares da filosofia política. (Cf. Law and Disagreement, p. 2)

${ }^{111}$ Para Dworkin, por exemplo, constitucionalismo seria uma "precondição necessária da democracia", "essencial para criar a comunidade democrática - para constituir "o povo"”. (V. "Constitutionalism and Democracy", p. 10). A fusão dos ideais da democracia e do constitucionalismo resulta no ideal da "parceria política" (political partnership), outra forma de Dworkin frasear o pertencimento moral do indivíduo à comunidade política (Cf. "The Partnership Conception of Democracy", p. 457). Zurn, por sua vez, critica o debate americano por estar geralmente obrigado a "distorcer" a democracia e a "contorcer" o constitucionalismo de modo a conciliá-los e a acomodá-los com a prática da revisão judicial norte-americana. Numa passagem que sintetiza a "contorção" do constitucionalismo: "In short, no judicial review, no constitutionalism". (V. Deliberative Democracy and the Institutions of Judicial Review, p. 22-23). O mesmo esforço de articulação foi também feito por diversos autores relevantes, como Michelman, Nino e Waluchow.
} 
A pergunta-título e a tabela binária correspondem a duas formas interrelacionadas de classificar as posições sobre o lugar da revisão judicial num governo legítimo. É mais difícil entender o desacordo pela tabela. Ela polariza e, sob aparência de simplicidade didática, perde em clareza. A pergunta mudaria nossa forma de enxergar o problema? Há algum ganho? A rigor, ela não elimina a necessidade de passar pelas mesmas categorias. Ela atravessa todas aquelas camadas mas inverte a ordem de investigação, partindo do concreto para o abstrato. É um instrumento que foca mais imediatamente na ação política (a autoridade de decidir) e que, além disso, incorpora uma dimensão temporal que viabiliza as teorias do diálogo.

Trata-se, em síntese, de uma moldura analítica mais ampla: quem e como e quando e por que decide sobre direitos numa democracia? Ao refrasear a questão, escapo da camisa-de-força binária e abro espaço para uma investigação mais produtiva: dos tipos de interação que aperfeiçoam ou maximizam a capacidade epistêmica da democracia. Não tento superar o problema anterior, nem esconder que, por trás dele, há necessariamente uma interpretação e um balanceamento de ideais políticos abstratos. Simplesmente inverto a seqüência e acrescento àquele uma nova questão que reduz a tradicional primazia da última palavra.

Basicamente, aqui, quero afastar o perigo de ficarmos reféns de disputas terminológicas. Não significa que os autores estudados não tenham sido consistentes nas respectivas definições e conceitos. O problema, exatamente, é que cada um estipulou uma definição ou elucidou um conceito diferente em nome de palavras parecidas (ou vice-versa). Nesta tese, também tenho que oferecer uma teoria da legitimidade política que permita posicionar-me nesses dilemas, o que será feito nos capítulos 6 e 7. "Democracia" e "constitucionalismo" inevitavelmente continuam a compor o argumento. Mais importante, porém, é entender que por trás dessa tarefa não está tanto um esforço de conciliação entre dois termos supostamente conflitantes, mas sim uma tentativa de estruturar institucionalmente um único ideal: o autogoverno coletivo, que implica em igual status moral de todos os cidadãos e culmina, por sua vez, em demandas formais e substantivas, como veremos mais adiante.

\section{Preâmbulo dos capítulos 2,3 e 4}


$\mathrm{Na}$ literatura do direito e da política, juízes e legisladores são retratados de maneiras múltiplas e conflitantes, cada uma das quais produzindo óbvias conseqüências em como concebemos seus papéis, interpretamos suas ações e defendemos seus limites e legitimidade. Teorias da separação de poderes costumam postular alguma expectativa em relação a ambos os atores. As imagens teóricas disponíveis se encaixam dentro de rótulos classificatórios diferentes. Recorrendo a uma dicotomia aqui já familiar, pode-se ensaiar alguns contrastes assimétricos entre versões otimistas e pessimistas desses dois agentes, conforme anunciei no tópico 3 acima.

Os capítulos 2 e 3 exploram modelos típico-ideais do melhor e do pior: o melhor modelo de juiz contra o pior modelo de legislador e vice-versa. Tento explorar o potencial de uma influente constatação de Waldron: a teoria do direito nos habituou a comparar uma "figura idealizada do juiz" (Hércules) com uma "figura desprezível e cínica do legislador", donde, previsivelmente, nasceu uma tradição de celebração da revisão judicial. ${ }^{112}{ }^{113}$ Esse quadro desbalanceado teria produzido uma séria miopia cognitiva. Tal desequilíbrio e falta de eqüidade teórica teria nos ensinado por meio de um esquema de pensamento problemático para falar sobre a democracia e o papel do controle de constitucionalidade. Waldron talvez não consiga escapar de sua própria provocação, invertendo o desequilíbrio em favor do legislador. ${ }^{114}$

\footnotetext{
${ }^{112}$ A passagem é a seguinte: "There is nothing about legislatures or legislation in modern philosophical jurisprudence remotely comparable to the discussion of judicial decision-making. No one seems to have seen the need for a theory or ideal-type that would do for legislation what Ronald Dworkin's model of judge, 'Hercules', purports to do for adjudicatory reasoning. (...) Not only do we not have the normative or aspirational models of legislation that we need, but our jurisprudence is pervaded by imagery that presents ordinary legislative activity as deal-making, horse-trading, log-rolling, interestpandering, and pork-barreling - as anything indeed, except principled political decision-making. And there's reason for this. We paint legislation up in these lurid shades in order to lend credibility to the ideal of judicial review (...), and to silence what would otherwise be our embarrassment about the democratic or 'counter-majoritarian' difficulties that judicial review is sometimes thought to involve. And so we develop and idealized picture of judging and frame it together with a disreputable picture of legislating". (The Dignity of Legislation, p. 1-2)

${ }^{113}$ C. Herman Pritchett, citado por Fisher, também faz constraste parecido: "Law is a prestigious symbol, whereas politics tends to be a dirty word. Law is stability; politics is chaos. Law is impersonal; politics is personal. Law is given; politics is free choice. Law is reason; politics is prejudice and selfinterest. Law is justice; politics is who gets there first with the most". (Cf. Fisher, Constitutional Dialogues, p. 9)

${ }^{114}$ Difícil dizer que Waldron não tenha cometido o mesmo pecado teórico ao, por um lado, ter insistido nos formalismos semânticos em que o juiz constitucional inevitavelmente estaria amarrado, viciando o debate moral; por outro, ao ter subestimado a importância de uma teoria da representação, restringido o argumento favorável ao legislador a uma teoria abstrata sobre igualdade e regra de maioria, e ignorado qualquer evidência sobre fatores da dinâmica eleitoral que influenciam o comportamento do legislador,
} 
A ciência política, conforme Waldron, seguiu um procedimento metodológico mais justo, e propôs um modelo cínico dos dois atores. ${ }^{115}$ Waldron, diferentemente das duas abordagens, tentaria elevar o apelo normativo da legislação e ver quais conseqüências derivar disso, como veremos adiante nesse trabalho. Inspiro-me nessa observação para montar a tabela abaixo, a qual tenta identificar quatro cenários teóricos puros que se originam das suposições pessimistas e otimistas sobre juízes e legisladores:

\section{Juiz}

\section{Legislador}

\section{Pessimista}

1

3

\section{Otimista}

2

4

Pretendo opor o argumento mais forte em favor da supremacia judicial e o argumento mais forte pela supremacia legislativa. Reconstruo o contraditório de maneira polarizada, observando os modelos de juiz e de legislador que, de forma excludente, levam alguns a optar pelo primeiro e outros a optar pelo segundo. São frutos de uma obsessão pela última palavra, de uma perspectiva estática da separação de poderes. Em vez de buscar o lado vencedor, o capítulo 4 descreve teorias que buscam encontrar um caminho virtuoso que combine as qualidades de ambas. Essas teorias fomentam a possibilidade de co-existência entre parlamentos e cortes constitucionais, sem a necessidade de escolher entre um e outro de modo mutuamente excludente.

\footnotetext{
o qual, mesmo que bem intencionado, pode também se ver num contexto decisório não ideal para promover uma deliberação moral de boa qualidade. Voltarei a esse ponto no tópico 6 (v. rodapé n. 116) e em outros momentos da tese. (Cf. Law and Disagreement e The dignity of legislation). Como disse Waluchow: "But in attempting to correct the imbalance, he seems to have rigged the debate in the opposite direction". (Cf. "Constitutions as Living Trees: An Idiot Responds", p. 49-50)

${ }^{115}$ Waldron continua sua provocação: "Political scientists do better of course. Unlike law professors, they have the good grace to match a cynical model of legislating with an equally cynical model of appellate and Supreme Court adjudication. Part of what I'm interested in doing in these lectures is to ask, 'What would it be like to develop a rosy picture of legislatures that matched, in its normativity, perhaps in its naivete, certainly in its aspirational quality, the picture of courts - the "forum of principle', etc. - that we present in the more elevated moments of our constitutional jurisprudence?" (The Dignity of Legislation, p. 1-2)
} 
Suponho que o argumento mais forte pela supremacia judicial e pela supremacia legislativa são, respectivamente, os dois cenários teóricos desbalanceados acima (2 e 3). Os outros dois cenários (1 e 4) oferecem argumentos mais fracos, e poderão também ser visualizados. Esses contrastes ajudam a estilizar algumas imagens frutíferas no debate sobre as teorias do diálogo. Tais imagens estilizadas não se encaixam com precisão na teoria de um só autor, mesmo que Ronald Dworkin e Jeremy Waldron tenham proximidade mais clara com os tipos puros 2 e 3 . É difícil superá-los no modelo do juiz e do legislador ideais. Não descrevo a posição integral de nenhum autor. Seleciono autores para exemplificar argumentos. Freqüentemente, os autores selecionados não se restringem ao ponto que destaco da teoria deles. Procuro construir duas posições abrangentes que, apesar da artificialidade, iluminem não somente os argumentos favoráveis à instituição preferida, mas também os respectivos argumentos contrários à outra (raramente bem articulados na literatura).

Em síntese, o próximo capítulo combina, para usar de uma expressão de Hart, ${ }^{116}$ o "nobre sonho" sobre juízes com o "pesadelo" sobre legisladores. É o capítulo de Hércules contra o legislador amoral (ou mesmo venal). O capítulo 3 faz o contrário: olha para o legislador virtuoso e para o juiz político e ideológico. Ambos os capítulos procuram suprir uma lacuna que torna vulneráveis e incompletas as teorias da última palavra. Tentam iluminar o edifício intrincado de problemas e argumentos favoráveis e contrários dos dois lados, em vez de atacar um sem levar a sério as objeções, que permanecem não respondidas. ${ }^{117} \mathrm{O} 4$, por fim, passa ao largo dessas suposições e verifica modos de interação. Mais do que um detalhamento de extensa literatura que essa discussão atravessa, apresento um mapa com espécies de argumentos e suas principais referências e fontes.

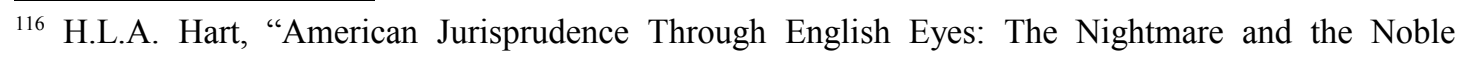
Dream".

${ }^{117}$ Uma seqüência alternativa para leitura dos capítulos 2 e 3 seria começar pela parte 2.1 (a favor da revisão judicial)), seguir para a 3.2 (contra), ir para a 3.1 (a favor de parlamentos) e voltar para a 2.2 (contra parlamentos). Não organizei a exposição nessa seqüência porque preferi manter a identidade conjunta de cada posição.
} 


\section{Capítulo 2}

\section{A inclinação por juízes e cortes constitucionais}

\section{Introdução}

Há numerosos argumentos em favor da supremacia judicial. Variam na função, freqüência e lugar que ocupam em teorias gerais da democracia constitucional. Em grande parte, não são excludentes ou conflitantes. Alguns se sobrepõem, distinguindo-se apenas na sua extensão. Outros aparentam dizer substancialmente a mesma coisa, mas variam nos termos e conceitos utilizados. Combinados, podem construir uma posição geral dotada de alguma consistência interna.

A tarefa do capítulo é descrevê-los sinteticamente. Cada um permitiria longas incursões críticas que fogem ao objetivo aqui. Mais do que entrar nos detalhes e desdobramentos, pretendo dar uma noção horizontal do conjunto. $\mathrm{O}$ eventual valor do capítulo, portanto, está em colocar lado a lado, de maneira sistemática, fragmentos que geralmente se encontram espalhados na literatura. $O$ pacote completo não costuma ser oferecido nas teorias da revisão judicial. Não quero dizer que tal teoria precise passar por todos os componentes abaixo enumerados, como se, cumulativamente, a posição se tornasse mais forte. No entanto, desconfio que muitas vezes peca por deixar alguns elementos mínimos nas entrelinhas, no terreno das suposições mal articuladas. Mais concretamente, conjugam argumentos em defesa da revisão judicial sem dar atenção ao outro lado da moeda - o parlamento, cujas qualidades ou defeitos são pressupostos e dados como certos. Essas ausências tornam difícil ter uma visão completa do edifício.

Argumentos institucionais devem ser postos num quadro comparativo em relação às alternativas existentes (ou mesmo às imagináveis e hipotéticas). Aqui lidamos com instituições existentes. Nesse sentido, além de apontar para eventuais qualidades da corte na proteção de direitos, há que se demonstrar também que o legislador é pior. E vice-versa, como faz o próximo capítulo. 
O capítulo se estrutura em duas partes. Na primeira, exponho os argumentos a favor de juízes e cortes. Na segunda, os contrários a legisladores e parlamentos. Cada argumento é apresentado por meio de uma frase-síntese que encabeça o tópico. $\mathrm{O}$ pano de fundo comum é que a corte deve ter a última palavra sobre direitos. Após cada frase-síntese, adiciono uma curta explicação sobre a idéia e, em rodapé, mapeio alguns autores representativos do ponto específico. A maioria dos argumentos tem como pano de fundo uma ou mais das dicotomias enumeradas no capítulo introdutório. A ordem de exposição começa pelas justificativas mais freqüentes e segue para outras de caráter complementar.

\section{A favor de juízes e cortes}

A corte constitucional, ao contrário do parlamento, jamais é percebida como elemento natural da democracia. Sua defesa toma como ponto de partida que o parlamento é indispensável, mas insuficiente. Nesse sentido, essa conexão teórica geralmente se expressa por verbos como proteger, preservar, potencializar e seus variantes. $\mathrm{O}$ ataque ao parlamento, por sua vez, consiste sempre numa tentativa de relativizar seu papel, não de suprimi-lo.

Cortes ocupam uma posição institucional especial, premissa dos argumentos abaixo: são compostas por membros não eleitos diretamente, mas escolhidos por algum método do qual participam autoridades eleitas; ${ }^{118}$ depois de nomeados, juízes ganham estabilidade e não podem ser retirados do cargo em razão de suas decisões; não estão, portanto, imediatamente sujeitos à dinâmica eleitoral e ao ritmo da alternância parlamentar; em razão disso, considera-se que estão imunes à prestação de contas e responsabilização política (são unaccountable, na acepção eleitoral de accountability).

\section{1 "A corte protege as pré-condições da democracia".}

Este argumento considera que a democracia não se realiza simplesmente pela existência de um legislador eleito que toma decisões por regra de maioria,

\footnotetext{
${ }^{118}$ Esses métodos variam de país para país. Nos EUA e no Brasil, por exemplo, é atribuição do Presidente nomear e do Senado aprovar. Em outros países, como a Alemanha, o poder legislativo participa mais ativamente dessa escolha.
} 
independentemente de outras condições. Aceita que uma agência externa ao parlamento possa desempenhar um papel de anteparo dessas pré-condições. Há duas versões dessa idéia, como veremos abaixo: a primeira aceita a interferência externa somente para preservar o procedimento de competição democrática; a segunda, mais ambiciosa, requer que decisões legislativas sejam submetidas a um controle de substância, de acordo com os princípios de justiça que a democracia pressupõe. O que une ambos, portanto, é a idéia de que a revisão judicial tem uma missão constitutiva da própria democracia a cumprir. Está em jogo, aqui, a tensão entre forma e substância.

\subsection{1 “A corte assegura o processo de formação da vontade democrática”.}

Procedimentalistas não são entusiasmados pela supremacia judicial. Ao contrário, concedem, de maneira contida, uma pequena margem de ação corretiva à corte. Aderem a vários argumentos apresentados no capítulo 3 e têm em grande conta os valores da representação e da regra de maioria.

Essa margem de ação corretiva diz respeito à preservação da competição política. ${ }^{119}$ A corte está legitimada a intervir somente quando identifica "falhas no mercado político". Tem, portanto, um papel "anti-truste". ${ }^{120}$ Preocupa a esses autores que as vias de expressão e canalização de projetos coletivos estejam bloqueadas a certos grupos isolados, que as possibilidades de mobilização e mudança estejam trancadas. O conceito que deu corpo a esse receio é o de "minorias separadas e insulares", presente numa decisão da Suprema Corte americana. ${ }^{121}$ Correspondem a grupos sistematicamente excluídos dos processos decisórios e desprovidos de qualquer voz.

\footnotetext{
119 "Court should not act as an elite impediment to what it takes to be the substantive excesses of the politically responsible branches but, on the contrary, as a perfecter of the democratic process". (Ely, "The Apparent Inevitability of Mixed Government", p. 290)

120 "The approach to constitutional adjudication recommended here is akin to what might be called an 'antitrust' as opposed to a 'regulatory' approach to economic affairs - rather than dictate substantive results it intervenes only when the 'market', in our case the political market, is malfunctioning". (Ely, "Toward a Representation-Reinforcing Mode of Judicial Review", p. 488)

${ }^{121}$ A expressão "insular and discrete minorities" está presente na nota de rodapé n. 4 do voto do Justice Stone no caso Carolene Products, 1938, rodapé mais famoso do direito constitucional americano. Robert Cover faz uma detalhada análise dessa nota de rodapé em "The Origins of Judicial Activism in the Protection of Minorities", p. 1293.
} 
A corte deve fiscalizar a participação e combater eventuais discriminações. $\mathrm{O}$ fato de não ser eleita facilitaria essa atividade. Deve ser protetora de direitos civis e políticos inerentes à competição, ao funcionamento e à manutenção dos processos decisórios: liberdade de expressão, de reunião, de associação partidária, o direito ao voto. Monitora a eqüidade procedimental. Preocupa-se em dar voz a setores marginalizados da sociedade.

A corte, nessa corrente, não pode imiscuir-se nas escolhas democráticas, nas grandes decisões do "povo". Precisa somente garantir que o jogo de interesses seja disputado sob bases igualitárias. Extrapolar essa função e adentrar no domínio dos juízos morais substantivos da democracia equivaleria a um "regime de guardiões", por meio do qual "o povo" é privado de governar a si mesmo e se infantiliza ao ter que se subordinar a uma elite que, supostamente, tem mais capacidade para fazer as escolhas por ele. ${ }^{122}$

\subsection{2 "A corte protege os direitos fundamentais e o conteúdo de justiça da} democracia".

A defesa da supremacia judicial abertamente ativista para a promoção de princípios de justiça criou duas eloqüentes representações da corte: o juiz "Hércules" e o "fórum do princípio". Ronald Dworkin é o representante obrigatório dessa visão. ${ }^{123}$ Seu ponto de partida é reconstruir a concepção de democracia para mostrar que, na medida em que este é um regime moralmente desejável, não pode contentar-se

\footnotetext{
${ }^{122} \mathrm{O}$ representante imediato dessa posição é John Hart Ely, que propôs a chamada "participationoriented, representation-reinforcing approach to judicial review", em oposição à "value-protecting approach" (Cf. "Toward a Representation-Reinforcing Mode of Judicial Review", p. 471). Defende um método não-interpretativista (não preso ao texto), mas que não caia nos excessos substantivistas. Para ele, o processo democrático é um mercado de interesses que devem ser agregados. Robert Dahl também segue linha parecida, e aceita a revisão judicial somente nesses termos, papel que ele chama de quasiguardianship (Cf. Democracy and Its Critics). Eu me arriscaria a incluir nessa corrente alguns autores que examinam a legitimidade da revisão judicial à luz da democracia deliberativa. Estes autores avançam para direitos mais ambiciosos, mas não chegam tão longe quanto Dworkin. Traçam uma linha divisória e param em algum ponto no meio do caminho. Refiro-me, principalmente, a Jürgen Habermas (Cf. Direito e Democracia), a Carlos Santiago Nino (Cf. The Constitution of Deliberative Democracy) e a Christopher Zurn (Cf. Deliberative Democracy and the Institutions of Judicial Review). Esse agrupamento, apesar de não fazer justiça às distinções entre essas duas correntes, me parece adequado por focar nas semelhantes recomendações práticas que, ao final, esses autores fazem à corte.

${ }^{123}$ Minha dissertação analisou extensamente os vários textos de Dworkin que constroem esse argumento. Outros autores certamente podem ser associados a essa linha de defesa, como John Rawls, Michael Perry e Laurence Tribe. Samuel Freeman e Stephen Holmes, que são mencionados no argumento específico do pré-comprometimento abaixo, também se encaixam nessa posição.
} 
só com procedimentos formalmente igualitários. O capítulo introdutório dessa tese já dedicou alguns parágrafos ao resumo desse autor e aqui me interessa apenas mencionar por que ele rejeita a opção procedimentalista do tópico anterior.

Para ele, como vimos, democracia é "um esquema procedimental incompleto", ${ }^{124}$ que persegue o ideal de "igual consideração e respeito". A realização desse ideal precede o procedimento majoritário. Em outras palavras, o procedimento não tem valor algum se, ao ser posto em marcha, não estiverem presentes as exigências daquele ideal. A dimensão quantitativa e estatística da democracia só goza de legitimidade, portanto, se não produzir decisões que desrespeitem suas próprias condições de legitimidade. Uma comunidade moral precisa existir para que a pura agregação de interesses, pela regra de maioria, possa demandar obediência. O método de mensuração da legitimidade é, portanto, conseqüencialista e instrumental.

Até aqui, uma lógica de raciocínio parecida com o argumento anterior. O que muda, efetivamente, é a extensão de "igual consideração e respeito", que abarca direitos não necessariamente relacionados com a estrita competição política. $\mathrm{O}$ tópico anterior, portanto, prevê que a revisão judicial com base em alguns direitos é legítima, e com base em outros, não. Para Dworkin, essa "fuga da substância" é operação insustentável e incoerente. ${ }^{125} \mathrm{O}$ juiz só poderia optar por proteger exclusivamente os aspectos procedimentais da competição política se fizer uma escolha substantiva prévia sobre qual a melhor concepção de democracia. Mas é justamente a recusa de que juízes façam escolhas substantivas que fundamenta aquela posição. ${ }^{126}$

A premissa escondida do argumento procedimentalista subverte, portanto, a sua pretensão. Para Dworkin, se concordamos que a democracia é compatível com uma instituição não-majoritária que toma decisões contra o legislador, não podemos parar no meio do caminho e separar alguns direitos em relação a outros, para evitar

\footnotetext{
${ }^{124}$ Freedom's Law, p. 32.

${ }^{125}$ A Matter of Principle, p. 58.

126 "Judges charged with identifying and protecting the best conception of democracy cannot avoid making exactly the kinds of decisions of political morality that Ely is most anxious to avoid: decisions about individual substantive rights" (Ibid, p. 64). "He thinks it allows judges to avoid issues of substance in political morality. But it does so only because the theory itself decides those issues, and judges can accept the theory only if they accept the decisions of substance buried within it". (Ibid, p. 67)
} 
que o juiz tome decisões substantivas. O juiz que adere a essa possibilidade já tomou uma decisão moral prévia.

\section{2 "A corte protege os direitos das minorias e impede a 'tirania da maioria"".}

Trata-se de uma pequena variação do argumento anterior, reformulado a partir da tensão entre minoria e maioria. É um argumento clássico que remonta a Aléxis de Tocqueville e John Stuart Mill e, a depender da interpretação, também aos Federalistas. "Tirania da maioria" é expressão de uso corrente no vocabulário político cotidiano e se mostrou bastante adequada para a justificação do papel e legitimidade da revisão judicial. ${ }^{127}$

Dito de maneira sintética, a democracia opera a partir da vontade da maioria desde que não reprima ou tiranize a minoria. Há, portanto, um limite à maioria, que concretamente vai depender de como se entenda "tirania". O tópico anterior, subdividido em duas vertentes, traduz melhor o aspecto procedimental ou a potencial dimensão substantiva desse limite. Negar a importância da proteção de direitos das minorias equivaleria a retomar argumentos de uma tradição intelectual insustentável e derrotada pela história. ${ }^{128}$

\section{3 “A corte é emissária do 'Povo' genuíno e operacionaliza o pré-} comprometimento".

Esta defesa da revisão judicial se baseia na distinção básica do constitucionalismo entre dois níveis de produção do direito, o ordinário e o extraordinário, que repercutem na hierarquia das normas. No momento extraordinário, cabe ao poder constituinte fundar juridicamente o estado por meio de uma constituição, ou reformá-la. No momento ordinário, o legislador produz leis. Para que este obedeça às grandes decisões de rumo daquele, uma corte constitucional precisa controlar o parlamento.

\footnotetext{
${ }^{127}$ Há muitos autores que se utilizam dessa expressão, sempre complementada por algum conteúdo mais específico. Cf. Oscar Vilhena Vieira (A Constituição e sua Reserva de Justiça).

${ }^{128}$ Waldron faz uma boa compilação e também analisa passagens de textos clássicos da "tradição antidireitos", em Nonsense Upon Stilts.
} 
Há duas formas diferentes de expressar essa idéia geral. A primeira pela conhecida concepção de dualismo constitucional de Bruce Ackerman. Para esse autor, a constituição institucionaliza uma vida política bipartida, separada em dois atos: a política constitucional ocorre em momentos especiais da história em que "o povo" se mobiliza e com virtude cívica toma decisões inspiradas no bem comum; a política normal é a política do puro interesse e barganha privados. A missão da revisão judicial, nesse contexto, é prestar contas ao "povo" que se manifesta nos momentos constitucionais. Não se trata propriamente, para Ackerman, de uma dificuldade contra-majoritária, mas apenas de uma dificuldade inter-temporal, pois o processo de emenda, quando "o povo" decide realizar alguma mudança na constituição e na interpretação da corte, consome um esforço maior e mais demorado. ${ }^{129}$

A segunda forma costuma ver o poder constituinte como um mecanismo de pré-comprometimento. É o momento em que Pedro sóbrio se manifesta, em que Ulisses, sabendo dos riscos e tentações que pode vir a sofrer quando diante do canto das sereias, decide amarrar-se ao mastro. ${ }^{130}$ Trata-se de uma decisão racional que, num momento de serenidade, reconhece o perigo de que em momentos mais conturbados a comunidade política possa ser guiada por paixões e suprima direitos fundamentais dos indivíduos. É um ato de auto-paternalismo.

Autores que recorrem à idéia de pré-comprometimento geralmente se adaptam bem à defesa substantiva da revisão judicial, exposta acima. ${ }^{131}$ Identifico duas versões de pré-comprometimento. Uma se realiza efetivamente como episódio histórico, por meio do poder constituinte. Se "o povo" aprovou a constituição, e esta adota a revisão judicial, significa que esse arranjo recebeu a chancela democrática. Outra procede por meio de uma especulação racional hipotética ao modo contratualista: imagina o conteúdo de uma constituição com a qual qualquer um concordaria se tivesse que escolher, no momento de fundação, os termos do contrato político que vincula a comunidade.

\footnotetext{
${ }^{129}$ Bruce Ackerman, "The Storrs Lectures: Discovering the Constitution".

${ }^{130}$ Essas imagens foram utilizadas por Hayek e Elster, e citadas por mim na minha dissertação de mestrado. (Cf. Controle de Constitucionalidade e Democracia, p. 11)

131 Cf. Stephen Holmes ("Precommitment and the paradox of democracy"), Samuel Freeman (“Constitutional Democracy and the Legitimacy of Judicial Review"), e Oscar Vilhena Vieira (ob. cit.).
} 


\section{4 “A decisão da corte pode ser rejeitada, ao final, por emenda} constitucional ou por uma nova constituição, poder que continua com o 'Povo'".

Este é um desdobramento da idéia acima: se "o povo" está insatisfeito com o desempenho da corte constitucional, nada impede que se mobilize para reformar a constituição ou criar uma nova por meio de revolução constitucional. A possibilidade de emenda seria a válvula de escape para amenizar os melindres majoritários dos que se opõem à revisão judicial. ${ }^{132}$

Caso "o povo" queira se manifestar, portanto, existirá sempre uma via ao seu alcance, seja ela por meio de emenda, seja pela refundação do regime. ${ }^{133} \mathrm{O}$ poder constituinte originário, supostamente a mais genuína expressão do "povo", desconfia do legislador ordinário e legitima a corte a praticar a revisão judicial enquanto estiver satisfeito com o desempenho da corte. Se não há reação do "povo constituinte" às posições da corte, significa que há um apoio tácito de fundo a elas.

\section{5 "A supremacia judicial é exigência do estado de direito".}

O estado de direito é um antigo ideal de subordinação do poder político a regras gerais, abstratas e não retroativas. ${ }^{134}$ Pretende combater a arbitrariedade e o abuso de poder por meio da institucionalização de um "governo das leis, não dos homens", ou, em outras palavras, de um governo da razão.

Com o advento da modernidade, o ideal do estado de direito tornou-se mais robusto e passou praticamente a confundir-se com o constitucionalismo. O poder político, assim, passa a estar subordinado a uma constituição, norma superior que deve ser obedecida por todos. Mais do que simplesmente evitar a arbitrariedade, a

\footnotetext{
${ }^{132}$ Cf. Owen Fiss, "Between Supremacy and Exclusivity", p. 201.

${ }^{133}$ Países como a Alemanha, Índia e Brasil adotam um modelo de máxima rigidez constitucional por meio de disposições que não são sequer passíveis de emenda. As cortes da Índia e do Brasil, ademais, já declararam a inconstitucionalidade de emendas constitucionais. Nessa situação, a única válvula de escape remanescente é a quebra institucional por meio de uma nova fundação constitucional.

${ }^{134}$ Esses são alguns dos elementos da moralidade interna do estado de direito, na canônica formulação de Lon Fuller (The Morality of Law).
} 
constituição também almeja propiciar certeza, previsibilidade e capacidade de planejamento, condições necessárias para o gozo da liberdade.

Se a constituição é suprema, o legislador não pode editar leis ordinárias que a desrespeitem. Caberia à corte constitucional, portanto, monitorar a compatibilidade das leis com a constituição. Seria o único modo de submeter, afinal, o poder político ao direito. Supremacia constitucional, nesse sentido, equivale à supremacia judicial. ${ }^{135}$ Constituição sem revisão judicial seria como o direito sem sanção, um mero conjunto de normas sem instrumentos de efetivação. Direitos fundamentais, para que tenham eficácia jurídica e sejam mais do que meros postulados morais, precisam do suporte judicial.

Não significa que a corte tenha a exclusividade na interpretação da constituição. Num regime constitucional, por definição, todos os poderes tomam suas decisões tendo em vista a constituição. Portanto, interpretam-na. Apesar do fenômeno rotineiro da interpretação extra-judicial, o estado de direito requer, em nome da estabilidade e em caso de conflito, que somente uma dessas autoridades - a corte defina o significado da constituição. ${ }^{136}$

\section{6 "A corte é um agente externo que julga com imparcialidade. $O$} legislador não poderia julgar a si mesmo".

Este é um argumento bastante conhecido na literatura. Aparece geralmente como apêndice do argumento anterior. Tem um apelo intuitivo. Se couber ao próprio legislador examinar a compatibilidade de seus atos com a constituição, ele fará inevitavelmente um julgamento em causa própria. Trata-se da aplicação do princípio da nemo iudex in sua causa. Se à maioria, nesse mesmo sentido, couber julgar quais são os limites da própria maioria, a desejada proteção das minorias não passaria de um embuste. ${ }^{137}$

\footnotetext{
${ }^{135}$ Esse é o raciocínio que inspira a invenção do controle de constitucionalidade pela Suprema Corte americana, na decisão Marbury v. Madison, de 1803. Tem estrutura lógica similar à defesa que Kelsen faz por uma corte constitucional. Os dois argumentos são bem analisados por Nino (The Constitution of Deliberative Democracy).

${ }^{136}$ Frederick Schauer e Larry Alexander sustentam tal argumento baseado no "rule of law" e sua respectiva necessidade de decisão única, estável, previsível ("On Extrajudicial Constitutional Interpretation"); Cf. também Owen Fiss ("Between Supremacy and Exclusivity").

${ }^{137}$ Dworkin, entre outros, invoca esse argumento.
} 


\section{7 "A corte é um veto inerente à dinâmica da separação de poderes”.}

A separação de poderes é uma ferramenta institucional do estado de direito. Seu princípio supõe que a diluição das funções faz com que os poderes controlem-se reciprocamente. Ao evitar a concentração de forças num único pólo, preserva a liberdade. Trata-se de um maquinário dotado de um mecanismo endógeno de limitação, não de uma norma exógena à qual os poderes prestam obediência. Não há uma substância normativa que os subordine. É a dinâmica puramente formal de interação que impede que eles extrapolem. Não passa de uma distribuição de capacidades de vetar e de estatuir. Nas palavras cruas de Madison, é um sistema em que "ambição se contrapõe à ambição", e cada poder tem que possuir mecanismos de defesa proporcionais ao perigo de ser atacado. ${ }^{138}$ Madison, inclusive, acreditava ser este o único modo de limitar o poder. Declarações de direitos seriam meras "barreiras de papel" contra a opressão. ${ }^{139}$

Não é porque o parlamento tem o pedigree democrático, portanto, que ele estará imune à tentação do abuso. Para diminuir esse risco, a separação de poderes cria vetos que reduzem a velocidade do processo decisório. Assim, é saudável que ao parlamento se oponha um contrapeso que ao menos possa combater a "política da histeria transitória". ${ }^{140}$

O argumento da dissertação de mestrado, conforme descrito no capítulo 1, baseou-se, em boa medida, nessa idéia. A revisão judicial seria um recurso institucional desejável não pela substância de justiça que supostamente resguardaria, mas sim pelo simples efeito moderador derivado desse processo. Não se compromete com a resposta certa, mas com o valor por trás dessa técnica formal.

2.8 "A corte analisa um caso concreto, submete-o a uma racionalidade incremental e o insere dentro de sua jurisprudência".

\footnotetext{
${ }^{138}$ Cf. James Madison, em Artigos Federalistas, n. 51.

${ }^{139}$ Cf. Tushnet, Taking the Constitution Away From the Courts, p. 167. Madison veio a mudar de idéia mais tarde, quando apoiou a aprovação do Bill of Rights americano por meio de emendas.

${ }^{140}$ Robert Cover, "The Origins of Judicial Activism in the Protection of Minorities", p. 1316.
} 
Este argumento começa a lidar propriamente com capacidades institucionais. A corte, em virtude de sua posição institucional, teria condições singulares para tomar certos tipos de decisão. Não seria um órgão que se legitima pelo critério populista, mas por uma expertise.

Essa expertise diz respeito à aplicação do direito ao caso concreto. Há uma divisão de trabalho jurídico entre os poderes. Cada um tem uma função típica que não deve ser misturada: criar regras, executá-las e adjudicar conflitos conforme essas regras. Melhor será a proteção dos direitos fundamentais quanto mais a decisão for sensível à particularidade do caso concreto.

Mesmo que rejeitemos a idéia de uma interpretação judicial isenta de vontade, que seja uma mera aplicação neutra do direito, ponto de vista mais obviamente implausível no terreno constitucional, o argumento não subestima a vantagem institucional da corte em relação ao legislador. Este é obrigado a produzir normas prospectivas, gerais e abstratas, que regula situações no atacado. Nem sempre terá facilidade para perceber as implicações de direitos fundamentais. Quando muito, é capaz apenas de especular sobre quais serão seus efeitos reais na sociedade. A corte, ao contrário, analisa a lei após essa ter sido processada por episódios reais. Mais do que isso, a corte é treinada numa metodologia decisória mais pertinente para lidar com as mínimas nuances morais de um caso de direitos fundamentais: decide caso a caso, de modo incremental, construindo uma jurisprudência rica em detalhes que a regra geral jamais poderá alcançar. Diferentemente do legislador, que olha somente para o futuro, a corte tem uma abordagem tanto retrospectiva quanto prospectiva (e modula os efeitos que a decisão presente terá em casos futuros). É uma metodologia que opera de baixo para cima (bottom up), dos casos concretos para generalizações modestas.

Abdicar desse recurso institucional traz grande prejuízo para a democracia. ${ }^{141}$ Promulgar declarações abstratas de direitos e responsabilizar cortes por desenvolvêlas gradualmente, a conta-gotas, não é um ato de arrogância cognitiva, como se um

\footnotetext{
${ }^{141}$ É a idéia defendida, por exemplo, por Jeremy Webber: "If legislatures or Executives made all the decisions, we would run the risk of losing sight of individuals' interests in our rush to achieve a social aim. (...) different types of institutions carry different advantages — and different biases — in rights definition. Courts excel at the sober analysis of specific claims in a manner that pays close attention to individuals and that is isolated (though only in relative terms) from broader political concerns". ("Institutional dialogue between courts and legislatures in the definition of fundamental rights").
} 
conjunto de verdades morais devesse ficar protegido do legislador ordinário. Antes, é um sinal de modéstia e do reconhecimento de nossa incapacidade de saber, por antecipação, quais são as melhores soluções para situações que envolvem direitos fundamentais. Não significa que essa função retrospectiva e caso a caso esteja vedada, teoricamente, ao legislador. Nas democracias contemporâneas, no entanto, é impraticável que ele assuma essa função.

Wil Waluchow é quem, recentemente, expôs uma versão refinada desse argumento. $^{142}$ A democracia, para ele, perde quando se limita à frieza e impessoalidade da regra geral prospectiva para lidar com situações de direitos fundamentais. Não se trata de cair na tentação do casuísmo, que romperia com a demanda do estado de direito de que casos iguais sejam decididos igualmente. A decisão judicial permite calibrar melhor do que a legislação o nível de abstração em que tais "casos iguais" serão estabelecidos. Nesse sentido, a corte também deve obediência às suas decisões passadas e permite que indivíduos extraiam dessas decisões regras que orientem sua conduta futura. A diferença é que o tipo de "casos iguais" com que a corte lida é construído com muito maior riqueza de detalhes.

Isso não se confunde com o desenho de uma versão cor-de-rosa do juiz, conforme Waldron poderia dizer. Mesmo que consideremos tanto juízes quanto legisladores agentes morais autônomos, de boa-fé e dignos de respeito, equiparar as duas situações decisórias seria uma grande simplificação. Waldron faria vistas grossas para diferenças relevantes. Toma a decisão legislativa como se estivesse nas mesmas condições da decisão judicial, o que faz o legislador "vencer" a disputa em virtude de sua credencial representativa. Não percebe que a perspectiva da corte, quando lida

\footnotetext{
${ }^{142}$ A Common Law Theory of Judicial Review. Waluchow insere este argumento na esteira da discussão sobre o método particular de adjudicação do common law. Isso levaria o leitor menos familiarizado com o assunto a sustentar que nos sistemas de civil law haveria metodologia diferente. Contudo, especialmente no plano constitucional, essas diferenças não se aplicam, tanto do ponto de vista prático (se verificarmos as semelhanças no modo como as cortes lidam efetivamente com precedentes), quanto teórico (por não ser sustentável a hipótese de que, por ser da tradição de civil law, a corte não deve nenhuma consideração a precedente). T.R.S. Allan percebe essa relação da técnica argumentativa do common law com a adjudicação constitucional: "Constitutional adjudication under a charter of rights is inevitably closer to common law legal reasoning, where the common law is developed as a vehicle for protecting rights, rather than to the narrower, more formal manner of statutory interpretation" (“Constitutional Rights and Common Law", p. 479). Fuller também tem percepção semelhante sobre a melhor posição do juiz em relação ao legislador, mas também alerta, com sensibilidade sobre capacidades institucionais, os perigos da tendência de advogados judicializarem questões que não se acomodam bem à forma decisória judicial. (Cf. The Morality of Law, p. 104 e 176)
} 
com questões de direitos fundamentais, tem maior probabilidade do acerto, e menor risco do erro grosseiro. É como Michelman caracterizou as vantagens institucionais do judiciário: “podem não ser mágicas, mas talvez não sejam negligenciáveis". ${ }^{143}$ Constitui uma salvaguarda institucional legítima da democracia. ${ }^{144}$

\section{9 “A corte é menos falível em questões de princípio e está mais próxima} da resposta certa".

Este argumento guarda algumas semelhanças com o anterior, e às vezes os dois se combinam numa única formulação. Aqui, todavia, a ênfase não é tanto na vantagem do caso concreto, mas sim no estado de espírito e ambiente institucional necessários para a decisão sobre questões de princípio.

O seu afastamento, ainda que relativo, das pressões da política eleitoral, e sua concentração exclusiva na dimensão de princípio, comparativamente aos inúmeros outros fatores que o legislador sopesa ao votar uma lei, confere ao juiz condições privilegiadas para decidir com isenção. Vale a pena ter uma instituição cuja função primária e exclusiva é decidir com base em princípio. ${ }^{145}$ A lógica eleitoral coloca direitos em risco e o ambiente parlamentar incentiva compromissos incompatíveis com a racionalidade dos direitos fundamentais. ${ }^{146}$ Separar o fórum em que predomina a utilidade do fórum em que predomina o princípio é uma sábia escolha institucional.

$\mathrm{O}$ arranjo institucional, portanto, faz com que juízes tenham compromisso e prestem contas somente à razão pública. Disso emerge uma racionalidade judicial com a qual o legislador não pode competir, ou ao menos, não com muita freqüência.

\footnotetext{
${ }^{143}$ Brennan and Democracy, p. 59.

${ }^{144}$ A literatura sobre a aplicação da "common law methodology" à discussão sobre legitimidade da revisão judicial tem alguns outros autores importantes. O próprio Dworkin, quando defende seu ideal de integridade no direito, se encaixa, em alguma medida, nessa tradição. A literatura sobre capacidades institucionais comparativas do judiciário e do legislador é também bastante variada. Duas referências clássicas são a escola do "Legal Process", liderada por Henry Hart e Albert Sachs, e também diversos textos de Lon Fuller (principalmente "The Forms and Limits of Adjudication"), onde ele distingue a competência de legisladores para lidar com conflitos policêntricos e de cortes para conflitos adversariais.

${ }^{145}$ Cf. Frank Michelman, Brennan and Democracy, p. 22.

${ }^{146}$ Dworkin tradicionalmente defende esse argumento: "Adding to a political system a process that is institutionally structured as a debate over principle rather than a contest over power is nevertheless desirable, and that counts as a strong reason for allowing judicial interpretation of a fundamental constitution". ("Democracy and Constitutionalism", p. 11).
} 
Como diz Owen Fiss: "Ver a corte trabalhar como deveria é ver a razão ser revelada". ${ }^{147}$ Não se pode desprezar, nesse sentido, que juízes lidam diuturnamente com uma demanda de justificação da qual depende sua autoridade. Só conquistarão credibilidade se efetivamente funcionarem como um fórum do princípio, condição que não lhes dá liberdade para decidirem o que quiserem.

Essa idéia foi rejeitada por muitos que a consideraram elitista, como se juízes fossem "reis platônicos", filósofos com habilidades superiores ao cidadão comum para um juízo moral. Tais críticas, no entanto, caricaturizam o ponto do argumento. Não se pede que juízes sejam filósofos, seja qual for o sentido místico e solene que essa palavra assume nessas críticas. Requer-se, sim, que ele lide com questões morais da maneira mais bem fundamentada possível. Esse exercício rotineiro faz com que ele desenvolva uma competência que esse ambiente institucional de deliberação estimula. ${ }^{148}$ Não se presume a infalibilidade, apenas a menor falibilidade do juiz. $\mathrm{O}$ fato de a corte ter discricionariedade não significa que não esteja num contexto de controle racional. ${ }^{149}$

\subsection{0 "A corte promove uma representação deliberativa e argumentativa".}

$\mathrm{O}$ argumento anterior sobre a especial capacidade judicial para a argumentação moral abre espaço para diversificar a noção de "representação" na política. Se a legitimidade democrática não se limita à agregação de interesses individuais, mas deve abranger decisões dotadas de boas justificativas compartilhadas por todos, conforme propõem teorias da democracia deliberativa, instituições políticas

\footnotetext{
${ }^{147}$ E ele continua: "Viewed as part of a larger political system, the judiciary's claim for authority, like that of any component, depends on its competency to perform its assigned task. (...) The competence of the judiciary derives not from the persons who are judges, but from the limitations of their exercise of power - limitations that commit the judiciary to what might be called public reason. Judges who fail to respect these limitations forfeit their authority and their claim to supremacy". ("Between Supremacy and Exclusivity", p. 203).

${ }^{148}$ Owen Fiss, novamente: "The foundation of judicial power is process. Judges are entrusted with power because of their special competence to interpret public values embodied in authoritative texts, and this competence is derived from the process that has long characterized the judiciary and that limits the exercise of its power. (...) We accept the judicial power on these terms". ("The Bureaucratization of the Judiciary", p. 1443). Ely também vê no processo contraditório a especial habilidade judicial: "Lawyers are experts on process writ small, the processes by which facts are found and contending parties are allowed to present their claims". ("Toward a Representation-Reinforcing Mode of Judicial Review", p. 485)

${ }^{149}$ Herbert Wechsler, Alexander Bickel, Ronald Dworkin, Frank Michelman, Owen Fiss, John Rawls, entre outros, são conhecidos por desenvolver esse argumento.
} 
devem ser capazes de dar conta dessa dupla demanda. Por essa razão, o parlamento eleito é representativo somente no primeiro aspecto da legitimidade. A corte é o candidato principal para cumprir a segunda demanda. Deve ser entendida como instituição representativa porque é mais sensível a razões, e não a desejos majoritários. Se, por um lado, não representa indivíduos particulares, por outro, participa de um processo altamente argumentativo onde as razões de todas as partes potencialmente interessadas são ouvidas. Indivíduos podem participar do processo decisório, às vezes de modo ainda mais intenso e influente, por fornecerem razões, não somente um voto. ${ }^{150}$

A corte decide por conta própria, mas dá resposta a cada um dos argumentos que lhe foram apresentados. ${ }^{151}$ Juízes que estão abertos a serem efetivamente influenciados pela diversidade de argumentos merecem nosso respeito por suas decisões. ${ }^{152}$ Ajudam a construir uma "república de razões", ${ }^{153}$ não somente uma "república de cidadãos" (ou de indivíduos auto-interessados). Seria mais provável encontrar o representante deliberativo defendido por Burke, nesse sentido, em cortes constitucionais, não em parlamentos eleitos periodicamente.

\subsection{1 "A corte é instituição educativa e promove o debate público".}

Para além de representar, a corte pode também educar. Provoca o debate público mais focado em argumentos de princípio do que em disputas partidárias ou estratégias de barganha. Sendo uma instituição com habilidade especial para decidir por meio de justificação pública e com base em princípio, ela estimula que as reações

\footnotetext{
${ }^{150}$ Dworkin também propõe esse argumento: "The public participates in the discussion (...) but it does so not in the ordinary way, by pressuring officials who need their votes or their campaign contributions, but by expressing convictions about matters of principle". ("Democracy and Constitutionalism", p. 11)

151 Há aqui também muitos autores que poderiam ser listados. Christopher Zurn faz uma boa comparação entre como John Rawls, Christopher Eisgruber e Frank Michelman se utilizam dessa idéia: o primeiro defenderia que a corte fala $n a$ linguagem moral apropriada para a relação entre cidadãos; na opinião do segundo, a corte falaria para o povo; para o terceiro, a corte falaria com o povo (Cf. Deliberative Democracy and the Institutions of Judicial Review, p. 175). Robert Alexy também defende a idéia de "representação argumentativa" ("Balancing, constitutional review and representation"). Por fim, pode-se dizer que os autores relacionados ao argumento do précomprometimento também têm uma demanda representativa para a corte, mesmo que ligeiramente diferente: representaria o povo nos seus momentos de maior engajamento cívico, o "povo constituinte". Hamilton, nos Federalistas n. 78, também aposta nessa idéia.

${ }^{152}$ Cf. Frank Michelman, Brennan and Democracy, p. 59.

${ }^{153} \mathrm{Cf}$. Cass Sunstein, The Partial Constitution.
} 
a tais decisões sejam feitas na mesma linguagem e isso enriquece a política. Sem essa instituição, o debate de princípio praticamente some da vida democrática, ao menos nos momentos de política ordinária. ${ }^{154}$

\subsection{2 “A corte integra um sistema democrático, não está à margem dele”.}

Este argumento retoma a separação de poderes. O governo democrático precisa ser versátil o suficiente para atender demandas de diferentes tipos, com base em diferentes critérios de legitimidade. A operacionalização desse ideal é complexa, e a invocação do mantra "governo do povo" não pode nos levar a pensar que significa "todos decidindo tudo todo o tempo". Por essa razão, há mediações institucionais, há separação entre governantes e governados. São mecanismos de distanciamento do povo e do poder político. A legitimidade, assim, deve ser atribuída ao conjunto, e não a componentes isolados dele. ${ }^{155}$

\subsection{3 "A corte é composta por membros indicados por autoridades} eleitas".

Por fim, de forma suplementar, este argumento mostra que juízes não estão completamente desconectados das instituições eleitas. Mesmo que, após nomeados, tenham estabilidade no cargo e, portanto, não se possa tirá-los de lá conforme uma avaliação retrospectiva de seu desempenho (como se faz na eleição), há um fio condutor de legitimação democrática. É verdade que esse vínculo vai se afrouxando com o passar do tempo, pois novas legislaturas assumem o poder e muitos dos mesmos juízes continuam na corte. ${ }^{156}$ No entanto, não se pode negar que com o tempo uma maioria sólida consegue compor uma corte afinada com seus interesses e posições. Não segue o ritmo eleitoral, mas não foge dele completamente.

\footnotetext{
${ }^{154}$ A "tese educativa" aparece principalmente em Dworkin e Bickel. Ela tem muita proximidade, porém, com o argumento do tópico anterior, e os autores lá mencionados ecoam essa idéia em boa medida. Barry Friedman, como veremos no capítulo 4, desenvolve uma teoria do diálogo bastante conectada a essa função de provocar o debate público.

${ }^{155}$ Owen Fiss elabora claramente essa idéia: "The democratic ideal should be applied to the political system as a whole and should not be used to ascertain the legitimacy of each component within the system. As a test of the system, democracy only requires that each component be linked to public officials and institutions that are responsive to popular sentiment. (...) Democracy only requires that those links between the judiciary and popular sentiment are sufficiently robust to justify the judiciary as part of the larger system". ("Between Supremacy and Exclusivity", p. 201)

${ }^{156}$ As possibilidades dessa dissonância variam de país para país, conforme adotem mandatos por prazo determinado ou vitalício.
} 


\section{Contra legisladores e parlamentos}

Defensores da revisão judicial não abrem mão do legislador representativo. Simplesmente negam a ele a última palavra em direitos fundamentais, reservando-lhe papel remanescente. Esses autores atacam o mito por trás da sensação de autogoverno que o parlamento estimularia. O mito teria entorpecido a capacidade de olhar para a instituição real e produzido uma ficção: porque elegemos nossos representantes para um mandato temporário, e porque eles decidem por maioria, estaríamos nos autogovernando e nossas preferências estariam promovendo igual impacto. Essa operação seria simplista. Institucionalizar ideais políticos é uma tarefa mais intrincada. O ideal do auto-governo individual e coletivo requer um conjunto de estratégias institucionais que não se esgotam no parlamento.

Divido os argumentos contrários a parlamentos em duas espécies: os que mostram problemas na representação e os que indicam os vícios escondidos na regra de maioria. Conforme já dito, a mínima explicitação das objeções ao parlamento pode tornar o argumento em favor da supremacia judicial mais forte.

\subsection{Contra a representação}

\subsection{1 “O parlamento não é a encarnação essencial da democracia, mas a conversão de uma instituição que historicamente exerceu outros propósitos".}

Fomos levados a acreditar que a tradução literal dos ideais da democracia e do "governo do povo" é o parlamento representativo. Este é hoje praticamente um truísmo político. A eleição passou a ser o evento democrático por excelência, o ato que permite ao regime pleitear ser membro do grupo. Democracias começariam por aí. O fechamento do congresso, por sua vez, é ato cuja simbologia está diretamente associada à ruptura do regime.

Para começar, deve-se contextualizar historicamente essa instituição. Celebrála como a quintessência da democracia parece transmitir um otimismo que ignora a sua origem oligárquica e assumidamente anti-democrática (um sistema de contenção 
montado por "aristocratas ingleses, fazendeiros americanos e advogados franceses"157).

Poder-se-ia dizer, é verdade, que sua origem aristocrática no século XVIII não impediu que, com a ampliação do sufrágio, ela tenha se convertido, gradualmente, numa instituição democrática. A versatilidade dessa instituição the teria permitido assumir diferentes bandeiras no decorrer do tempo. No entanto, se é possível dizer que o sufrágio permitiu uma ampliação da participação, o mesmo não é verdade em respeito ao seu aprofundamento. Adicionou-se um elemento democrático ao sistema, mas sua essência elitista continua a subsistir. ${ }^{158}$ A eleição é, por si só, um mecanismo oligárquico e anti-igualitário. Ela exclui e discrimina. Não se permite ao povo governar, ainda que indiretamente, mas apenas selecionar seus governantes e julgar seu desempenho, periodicamente. ${ }^{159}$ Essa dualidade nos autoriza a ver nesse arranjo, no máximo, a "constituição mista dos tempos modernos". ${ }^{160}$

\subsection{2 "A dinâmica representativa-eleitoral incentiva um comportamento} legislativo que barateia direitos fundamentais".

O parlamento, da maneira como é composto, não permite que se leve direitos a sério. Legisladores têm, às vezes legitimamente, muitas outras coisas na cabeça. São influenciados por um conjunto de incentivos mais imediatos, ligados à conveniência da política pública. ${ }^{161}$ Direitos, quando aparecem na balança, são um entre outros componentes, não a preocupação primária. Na escala moral de um regime que respeita liberdades, porém, direitos são trunfos. Não podem ser um fator a mais de negociação e de barganha. Com eles, não há espaço para trade-offs.

Essa, porém, ainda é uma imagem otimista do parlamento. Com mais freqüência, direitos sequer fazem parte de uma agenda remota. O comportamento dos representantes é voltado, na maior parte do tempo, a satisfazer interesses imediatos de

\footnotetext{
${ }^{157}$ Cf. Bernard Manin, The Principles of Representative Government, p. 234.

${ }^{158}$ Como afirma Nadia Urbinati: "A Janus-faced institution, elections give representation a democratic face and democracy an aristocratic twist". (Representative Democracy, p. 3)

${ }^{159}$ Ibid, p. 162.

${ }^{160}$ Ibid, p. 238.

${ }^{161}$ Cf. Pickerill, Constitutional Deliberation in Congress, p. 64-65.
} 
seus eleitores. ${ }^{162}$ Suas motivações se reduzem a uma variável simples: escolherão tudo aquilo que aumentar as chances de reeleição e de ampliar o poder individual. São, nesse sentido, agentes políticos auto-interessados. ${ }^{163}$

Parlamentos são, ainda, foros destinados à retórica, à teatralização e à opinião forte, nada que se compare a um foro deliberativo sereno, em que pessoas argumentam sinceramente para tentar convencer seus pares, respeitam o desacordo e estão abertas a serem convencidas. Ao contrário, discursos se dirigem à audiência externa, a marcar posições que resultem em votos nas eleições. ${ }^{164}$

\subsection{3 “A representação eleitoral não é o único tipo possível de} representação. Trata-se de uma representação puramente agregativa, atomística, que pensa a política como mercado".

Este argumento se conecta com o argumento 2.10 acima (em defesa de cortes como "representantes deliberativos"). Basicamente, reitera que a escolha eleitoral de representantes não esgota a representação. Na política democrática contemporânea, é apenas uma modalidade. ${ }^{165}$ A suposição não questionada de que a representação eleitoral tem uma qualidade inerentemente democrática não é neutra e incontroversa. Instituições desenhadas conforme diferentes critérios carregam vantagens e desvantagens entre si. Não se pode dizer que a competição eleitoral só traz vantagens, todo o tempo, para a decisão de todos os temas.

A sensação de auto-governo não se esfacela simplesmente porque a última palavra, em alguns assuntos, não é do parlamento, mas de juízes. Nem sempre, só porque não os elegemos, será impossível considerar a decisão judicial como "nossa". Ao contrário, se o legislador não respeitar direitos e prevalecer sobre a corte, nossa percepção de auto-governo coletivo diminui. Eventualmente, preferimos nos aliar a

\footnotetext{
${ }^{162}$ Comportamentos apelidados de log-rolling, pork barreling, horse-trading etc.

${ }^{163}$ Essa é a premissa com base na qual a ciência política costuma analisar a política legislativa e as relações entre os poderes executivo e legislativo. (Cf. David Mayhew, Congress: the Electoral Connection, Yale University Press, 1974.)

${ }^{164}$ Cf. Diego Gambetta, “'Claro!' An Essay on Discursive Machismo”.

${ }^{165} \mathrm{O}$ ato deliberado da escolha do representante, inclusive, não é elemento necessário para o ato de representar. Há diversos exemplos de situações em que o representante não foi escolhido pelo representado. Waluchow desenvolve esse argumento com maior profundidade (Cf. Common Law Theory of Judicial Review, p. 81 e ss)
} 
um bom argumento do que ao representante em quem votamos. Não que a corte sempre consiga produzir tal bom argumento. Quer-se apenas mostrar que o fenômeno do auto-governo é mais sutil e abrangente do que escolher, periodicamente, por meio do voto, um representante.

A partir do momento em que há necessidade prática de separação entre governantes e governados (pois não estaríamos mais, com Rousseau, no cantão de Genebra, como diria Michelman), restam nas instituições democráticas apenas "rastros de auto-governo", em diferentes graus, em diferentes modalidades. O "fetichismo do governo representativo" não é melhor do que o fetichismo da corte. ${ }^{166}$

Por fim, deve-se também dizer que a eleição não dá mais conta de criar um órgão representativo suficientemente plural que reflita a diversidade da sociedade atual. A idéia de que o parlamento, em alguma medida, espelha a sociedade é cada vez menos plausível num momento em que um único representante ou um único partido não consegue carregar, em bloco, as preferências de seus eleitores. ${ }^{167}$

\subsection{4 "Restrições ao parlamento eleito não resgatam argumentos da} tradição anti-democrática. Simplesmente apontam problemas que os incentivos institucionais geram no comportamento do legislador".

Defender que uma corte, em alguns assuntos, possa prevalecer sobre a decisão legislativa não guarda nenhuma relação com as clássicas inclinações antidemocráticas (o preconceito contra as massas, o despreparo do cidadão comum, a necessidade de guardiões etc.). Trata-se, apenas, de levar instituições a sério. Juízes não são melhores do que ninguém, nem possuem capacidades argumentativas superiores. Estão apenas num ambiente institucional mais adequado para um determinado tipo de decisão (não outros, certamente).

\footnotetext{
${ }^{166}$ Como diz Frank Michelman: "Congress is not us. The President is not us. The Air Force is not us. We are not 'in' those bodies. Their determinations are not our self-government. Judges overriding those determinations do not, therefore, necessarily subtract anything from our freedom, although the judges also, obviously, are not us. Their actions may augment our freedom. As usual, it all depends. One thing it depends on, I believe, is the commitment of judges to the process of their own selfgovernment". ("Foreword - Traces of Self-Government", p. 75). Nesse texto, a distinção entre representação efetiva e virtual também é útil para aprofundar o tema aqui.

${ }^{167}$ Cf. Gargarella, "Full Representation, Deliberation and Impartiality".
} 
É surpreendente, por exemplo, como a complexidade congressual passa ao largo do argumento de Waldron contra a revisão judicial. Para ele, o congresso é um conjunto de representantes que decide por maioria. Numa escala menor, corresponde ao povo tomando suas decisões em conjunto pelo procedimento mais igualitário possível. Sua teoria normativa é tão abstrata e rasa quanto isso. $\mathrm{O}$ resto - comitês, hierarquia partidária, poder de agenda etc. - parece ser mero detalhe. Seria produto de uma visão cínica sobre a pessoa do representante eleito. Não percebe que legisladores, mesmo bem intencionados e virtuosamente orientados ao bem comum, estão imersos numa rede de constrangimentos institucionais incontornáveis pela virtude. Os problemas da representação eleitoral e da regra de maioria não desaparecem.

Waldron trata parlamentos e cortes como se fossem institucionalmente equivalentes. Variam apenas quais e quantas cabeças serão contadas. Não se atenta para como a forma institucional importa e não percebe que as virtudes do parlamento são parciais e relativas. ${ }^{168}$

\subsection{Contra a regra de maioria}

\subsection{1 "A regra de maioria é insensível à intensidade de preferências".}

Um procedimento majoritário, na base de votos com peso idêntico, não consegue captar a relevância que a matéria votada tem para cada indivíduo. É uma conseqüência da igualdade formal que o inspira. Alguns, geralmente minorias engajadas, têm no tema a prioridade de sua agenda. Outros estão em dúvida. ${ }^{169}$ Outros, ainda, são indiferentes, e não se importam com sua aprovação ou reprovação. $\mathrm{O}$ fato de as três partes entrarem, com igual poder, na contabilização dos votos, faz

\footnotetext{
${ }^{168}$ Como afirma Keith Whittington: "In striving to paint a rosy picture of legislatures, Waldron analysis suffers from an unwillingness to consider basic aspects of institutionalized politics. (...) Taking institutions seriously becomes particularly important in evaluating the justifications for judicial review and engaging in the type of comparative institutional analysis that Waldron advocates". ("In Defense of Legislatures", p. 696-697)

169 Aqui, o problema diz respeito ao lugar que na democracia ocupa aquele que está em dúvida, que não concorda nem discorda, que não duvida da possibilidade de haver uma resposta certa ou mais próxima da verdade. Ele pode até engajar-se na tentativa de descobrir a melhor solução, mas simplesmente não sabe, não está convencido e não se sente confortável para integrar a maioria ou a minoria.
} 
com que os primeiros sejam prejudicados. A regra de maioria promove, no máximo, a igualdade de impacto, um ideal insuficiente de igualdade. ${ }^{170}$

\subsection{2 "A regra de maioria não tem a racionalidade que parece. Seu} resultado é arbitrário".

Kenneth Arrow demonstrou que a votação por maioria nem sempre traz, como produto automático, a "vontade da maioria". Diferentes decisões resultarão desse procedimento pela simples variação da ordem de votação. Quem tem o poder de controlar essa ordem consegue, muitas vezes, determinar a decisão final. É o que chamou de "ciclo da votação". Constatou que o procedimento majoritário, em vez de encontrar uma "vontade da maioria" (a qual poderia culminar na "tirania da maioria"), mais provavelmente culmina ou na "tirania de uma minoria estrategicamente bem posicionada" ou na "tirania do arbítrio irracional". ${ }^{171}$

\subsection{3 “O mundo não é bipartido entre maioria e minoria. Preferências} políticas, ademais, não são estáticas".

Em alguma medida, este argumento desdobra os anteriores. Questiona-se como a "dificuldade contra-majoritária" concebe as escolhas coletivas. Esta dividiria a sociedade em dois grupos, assumindo o parlamento como maioria e o tribunal como minoria. Pensar em termos de maioria e minoria, entretanto, é esconder complexidade. A premissa de que a decisão do parlamento repercute a vontade da maioria parece supor que ali existe uma simples agregação de posições prontas, préformadas, convictas e inflexíveis. Nossas preferências, porém, são maleáveis e sujeitas a transformações por meio do debate, da experiência, de novas informações etc. Não são fixas e exógenas (pré-políticas), mas mutáveis e endógenas. ${ }^{172}$ Elas se

\footnotetext{
${ }^{170}$ Segundo Dworkin, a igualdade de impacto é uma noção pobre, e a igualdade de influência um ideal inatingível e indesejável. Por essa razão, segundo ele, devemos antes nos preocupar com a "igualdade de consideração e respeito" que o tribunal poderia promover. (Cf. Freedom's Law, cap. 1)

${ }^{171}$ Ian Shapiro, The State of Democratic Theory, p. 12.

${ }^{172}$ Barry Friedman, autor que detalharemos no capítulo 4, resume essa posição: "In a sense the countermajoritarian difficulty treats popular will as the aggregation of fixed exogenous preferences, when preferences necessarily are shifting and endogenous. Preferences are continually shaped and reshaped by public opinion. Every minute is an ordering and reordering for each of us about what we want and care about. The assumption that there is a 'majority' whose 'will' is embodied in governmental decisions is, at best, overstated. Decisions must be made at specific times. At best, there may be one brief moment when governmental decision does represent majority will, though that moment may come and go in an instant as views and choices change. The political process cannot
} 
estruturam num contínuo e não numa escala binária. Somos contra e a favor em diferentes graus.

A sociedade não está dividida entre duas alternativas estáticas. A votação final de um projeto de lei, por exemplo, não pode ser vista como uma divisão entre aqueles que a aprovam e os que a rejeitam, pois isso ignoraria todo o processo anterior de composição de diferentes graus de interesse. Legisladores íntegros poderão ter escalas de preferências morais sinceras (não meramente escalas de interesses egoísticos), mas, de qualquer modo, terão que compor.

A "vontade da maioria", enfim, não é um bloco monolítico e uníssono, mas heterogêneo. Seus componentes fizeram concessões à esquerda e à direita. Mesmo que estivesse isenta do problema apontado por Arrow, não é uma entidade facilmente identificável. Menos ainda no decorrer do tempo. Não há estabilidade e continuidade. A sintonia entre opiniões do povo e de seus representantes, quando há, é efêmera. Se assim é, o que as cortes revogam pelo controle de constitucionalidade não pode ser, exatamente, a vontade da maioria.

\section{Quem e como e quando e por que decide sobre direitos numa democracia constitucional?}

Esse capítulo tentou sistematizar diferentes caminhos para responder à "dificuldade contra-majoritária". Desenhou um modelo ideal de juiz e corte constitucional. Adotou uma estratégia expositiva intercalada: na defesa, um argumento positivo pela revisão judicial; no ataque, um argumento negativo contra a absoluta supremacia parlamentar.

Cortes devem decidir por último sobre direitos pela conjugação de razões formais e substantivas de legitimidade e pela sua capacidade institucional de colocálas em prática. Tem vantagem comparativa em relação, pelo menos, à alternativa cogitada: o parlamento.

possibly reflect individual's and society's constantly changing preferences". ("Dialogue and Judicial Review", p. 641) 


\section{Capítulo 3}

\section{A inclinação por legisladores e parlamentos}

\section{Introdução}

Esse capítulo adota estratégia expositiva semelhante à do anterior, mas inverte os sinais. Ataca e defende em sentido contrário. Tem o mesmo objetivo horizontal: dar uma noção da multiplicidade de argumentos envolvidos no debate, não dos detalhes de cada um.

Estrutura-se também em duas partes. Começo pelos argumentos em defesa da supremacia dos parlamentos representativos. Na segunda parte, abordo os contrários à revisão judicial. Há um paralelismo quase linear com o capítulo 2, em especial entre os argumentos relativos à revisão judicial.

\section{A favor de legisladores e parlamentos}

Ao contrário de juízes e cortes, a relação de legisladores e parlamentos com a democracia é tida como mais óbvia e natural. Não tem um ônus especial de justificação. Por essa razão, essa instituição não só preserva, suplementa ou dinamiza a democracia. Encarnar, espelhar e representar são verbos mais adequados para as teses aqui enumeradas.

$\mathrm{O}$ argumento em favor da supremacia legislativa soma, pelo menos, dois valores: (i) a representação eleitoral, ${ }^{173}$ recurso usado para replicar, em menor escala, o povo, e (ii) a regra de maioria, recurso procedimental que promove a igualdade. ${ }^{174} \mathrm{~A}$ literatura constitucional tende a ser superficial nesse aspecto e a assumir como

\footnotetext{
${ }^{173}$ Poderia ir mais longe no exercício e optar pela vertente considerada ainda mais democrática da representação, a sua modalidade proporcional. Para os fins do argumento, esse passo é desnecessário.

${ }^{174}$ Seria possível ainda somar três elementos ao conjunto: (iii) a sabedoria da multidão (usado por Waldron, inspirado em Aristóteles e Condorcet, para defender a maior capacidade epistêmica de um foro deliberativo grande), que descarto por achar menos plausível; (iv) o elemento deliberativo interior ao parlamento, apesar de a literatura não considerar este um ponto favorável ao legislador (cf. Pickerill, Constitutional Deliberation in Congress); (v) a competência institucional específica para lidar com "conflitos policêntricos", em oposição à capacidade para lidar com conflitos adversariais dos tribunais, conforme Lon Fuller elaborou em texto clássico ("The Forms and Limits of Adjudication"). Este último foi absorvido, em alguma medida, pelos argumentos favoráveis à representação, pois seu detalhamento extrapolaria o objetivo do capítulo.
} 
postulado não-problemático o legislador como institucionalização da vontade popular majoritária por excelência. Tento coletar os argumentos mínimos que podem explicitar melhor essa suposição.

A presença de Waldron continua intensa em partes desse capítulo. Mais de cinco anos após seu último livro sobre o assunto, e à luz das intensas reações que gerou na teoria constitucional, este autor voltou recentemente ao tema. Em novo texto, pretende apresentar o que chama de "argumento essencial" contra a revisão judicial. ${ }^{175}$ "Essencial” porque não está vinculado a constituições nacionais específicas, e não invoca exemplos de decisões históricas de qualidade exemplar. Cortes e parlamentos tomam decisões boas e más. Ambos falham e acertam. Quer um argumento de pretensão universal que passe por cima de considerações paroquiais e de decisões específicas.

Há novidades em relação às numerosas publicações anteriores. Waldron passa a admitir que, em situações excepcionais, a revisão judicial pode ser desejável, mas permanece convicto de sua raiz antidemocrática. A defesa da supremacia do parlamento, portanto, torna-se relativa e condicionada. Esclarece também que seu alvo é o modelo forte de revisão judicial de matriz americana, que possibilita a um tribunal não eleito revogar uma lei e dispor de autoridade última na interpretação constitucional. Admite que modelos fracos possam ter alguma contribuição útil. ${ }^{176}$ Cria uma distinção importante entre "situação típica" e "situação atípica ou patológica". ${ }^{177} \mathrm{Na}$ primeira, a revisão judicial é ilegítima, indesejável e desnecessária. $\mathrm{Na}$ segunda, ela pode ser aceitável, desde que se demonstre que a corte, em comparação à alternativa parlamentar, protegerá direitos de modo mais eficaz.

A espinha dorsal do argumento está na compreensão da "situação típica". Ela compreende quatro componentes: (i) instituições democráticas em bom funcionamento; ${ }^{178}$ (ii) instituições judiciais não representativas em bom

\footnotetext{
175 "The core of the case against judicial review", 2006.

${ }^{176}$ A distinção entre modelos fortes e fracos será melhor explicada no capítulo 4, quando descrevo brevemente os modelos canadense, britânico, e neo-zelandês.

${ }^{177}$ Essa foi a tradução imperfeita que adotei para as expressões "core" e "non-core situations".

${ }^{178}$ Waldron explica rapidamente o que ele quer dizer com isso: parlamento representativo eleito por meio de sufrágio universal, realização de eleições periódicas, legisladores que levam a sério seu papel de representantes, o parlamento como órgão deliberativo acostumado a lidar com questões de justiça etc. (Ibid, p. 1361).
} 
funcionamento; ${ }^{179}$ (iii) um compromisso genuíno da maioria da sociedade com a idéia de direitos; (iv) um persistente desacordo de boa-fé sobre direitos. Os dois primeiros, portanto, envolvem condições institucionais. Os dois últimos, culturais.

Se um desses quatro componentes não estiver presente, e isso for um estado endêmico, estaremos diante de uma "situação atípica e patológica". Não significa, como vimos, que a revisão judicial seja a alternativa automática: há ainda o ônus de se justificá-la no contexto específico. Eventualmente, os custos de se recorrer a tal instituição elitista podem ter que ser pagos em função de parlamentos disfuncionais, de culturas políticas corruptas, de legados de racismo etc. Só nessas circunstâncias a revisão judicial faria sentido. Não pode ser vista como "epítome do respeito a direitos" ou como elemento sempre desejável das democracias. É uma solução não ideal para circunstâncias extraordinárias.

Por um momento, pode-se pensar que Waldron se tornou um defensor da revisão judicial para o mundo real, enquanto continua a relativizá-la do ponto de vista normativo. Não é a quintessência da democracia, mas seria aceitável diante da realidade. O autor, contudo, insiste que suas demandas para o "caso típico" não são irrealistas ou utópicas - não exige instituições perfeitas ou infalíveis, mas apenas que estejam em bom funcionamento, orientadas pelo princípio da igualdade e capazes de monitorar-se e de corrigir-se. Waldron parece otimista quanto à existência da situação típica em boa parte das atuais democracias que adotam a revisão judicial.

Sua tese geral contra a revisão judicial já é conhecida. ${ }^{180}$ Baseia-se, sobretudo, numa apreciação do direito à participação e da regra de maioria. Curiosamente, como se sabe, sempre fez a defesa da supremacia legislativa sem contar com uma teoria da representação, exceto na forma de uma suposição genérica e rápida. No novo texto, ela continua ausente. Dá apenas algumas indicações de que uma teoria completa da legitimidade precisa lidar com duas perguntas: Por que determinadas pessoas decidem? Por que se utilizam de um dado procedimento? A resposta para a primeira seria uma teoria de eleições eqüitativas; para a segunda, uma teoria sobre o valor moral da regra de maioria. A "teoria de eleições eqüitativas", apenas esboçada

\footnotetext{
${ }^{179}$ Cortes não são eleitas, e portanto não estão permeadas pelo "ethos" da representação eleitoral, o que é importante para sua função no interior do estado de direito.

${ }^{180}$ Dedico o capítulo 3 da minha dissertação de mestrado a isso.
} 
abstratamente ali, não me parece ainda satisfazer às demandas de uma teoria da representação. Essa ausência é surpreendente, ainda mais quando se lembra que Waldron muitas vezes insistiu em dizer que a corte também decide por maioria, e que o elemento distinto do parlamento seria outro (justamente o atributo que ele deixou de desenvolver com a atenção que dedicou à regra da maioria).

Abaixo delineio alguns dos argumentos tradicionais em nome desses dois valores principais por trás do parlamento eleito. Tento iluminar questões que precisam ser melhor trabalhadas para preencher as lacunas da teoria de Waldron.

\subsection{A favor da representação eleitoral}

A prática da representação envolve muitos aspectos controversos mal resolvidos pela teoria política. Debaixo de significativo consenso sobre quais são as instituições representativas e o papel central das eleições, há um grande desacordo sobre o que significa, afinal, "representar", e quais são os deveres do representante. ${ }^{181}$ Várias possibilidades aparecem: atender aos interesses expressos de seus eleitores; seguir a opinião pública; buscar descobrir o que seus eleitores decidiriam se estivessem na posição privilegiada do parlamento, com a riqueza de informações e de debates ali disponíveis; tentar entender os interesses genuínos e autênticos de seus eleitores, mesmo que seja necessário ir contra os desejos expressos deles; ${ }^{182}$ atender ao melhor interesse de toda a sociedade e buscar as melhores respostas por meio de deliberação sincera etc.

Naturalmente, a resposta a essas dúvidas determinará o maior ou menor apelo normativo do parlamento representativo na democracia, e também a construção de incentivos institucionais para possibilitar aquele comportamento que seja mais compatível com esse regime. Os argumentos abaixo passam ao largo dessas discussões. Assumem que o parlamento cumpre a missão de representar, seja ela qual for.

\footnotetext{
181 Nadia Urbinati ilumina essa distinção: "Elections 'make' representation but do not 'make' representatives. At a minimum they make responsible and limited government, but not representative government". (Representative Democracy, p. 224)

${ }^{182}$ Sobre a distinção entre interesses autênticos e inautênticos dos representados, cf. Waluchow, $A$ Common Law Theory of Judicial Review, p. 86.
} 


\subsection{1 “O parlamento representativo é o mais próximo que se pode chegar} do ideal de democracia nos estados modernos (second-best choice). É manifestação do povo, ainda que indireta".

A representação é um recurso pragmático para contornar dificuldades que tornaram inviável a adoção do padrão democrático original. Nas sociedades modernas, dadas sua dimensão e complexidade, indivíduos não podem ocupar-se da política todo o tempo. A magnitude do demos e a extensão geográfica dos estados nacionais, ademais, não permitem reuni-los numa assembléia. Sua participação somente pode ser limitada e periódica. Dada a inviabilidade de implementar o ideal, a representação, ao menos, é uma aproximação, um mal menor. O povo se faz presente por meio das eleições, e governa, ainda que indiretamente, por intermédio de seus representantes. ${ }^{183}$ Mesmo que a idéia de "vontade da maioria" possa ser problemática, o parlamento é representativo e isso basta para rejeitar uma instituição judicial que, se não é necessariamente contra-majoritária, é contra-representativa.

\subsection{2 "O processo de composição do parlamento representativo estrutura} a competição política".

A escolha pragmática da técnica representativa viabilizou a democracia não tanto porque o povo teria passado a governar indiretamente. A idéia de busca de uma vontade comum por meio de instituições representativas é equivocada. Esse processo, porém, disciplina e estimula a competição política em bases eqüitativas, e permite ao eleitor escolher e rejeitar os competidores. O que define tal regime como democrático é o igual direito de qualquer cidadão de votar e de ser votado.

\subsection{3 "O parlamento representativo é um aperfeiçoamento da democracia} direta (first-best choice)".

Enxergar a representação como uma aproximação de um ideal em face da inviabilidade prática de sua completa realização corresponde a uma visão empobrecida da política e da democracia. Urbinati, recentemente, buscou construir

\footnotetext{
${ }^{183}$ Cf. Nino, The Constitution of Deliberative Democracy, p. 171.
} 
uma fundamentação normativa da representação que atendesse à provocação de Thomas Paine: "Atenas, através da representação, teria superado sua própria democracia". ${ }^{184}$ Representação, nesse sentido, é um salto de qualidade e um aperfeiçoamento, não um retrocesso.

Segundo ela, a representação traz à tona a dimensão do julgamento e da deliberação na política. Impede a primazia da decisão e do voto, e que a política se reduza e seja devorada por atos de vontade, na dimensão do "aqui e agora" (“presentismo"). ${ }^{185}$ Num governo direto, a presença física e o imediatismo são a mola mestra da vida política. Com a representação, consegue-se transformar a presença física em presença por meio da voz, conectar as esferas formal e informal da política num contínuo de influência e deliberação. Acima de tudo, multiplica as dimensões temporais da política e torna a democracia capaz de enxergar o longo prazo, de olhar o futuro e de aperfeiçoar-se continuamente. Sem a mediação representativa, a política fica refém dos espasmos do voto.

\subsection{4 "A atividade decisória do parlamento estimula o compromisso, a} acomodação de extremos, não a polarização".

Ainda que as idéias de "representação do povo" e de "vontade da maioria" não sejam persuasivas, deve-se levar em conta a qualidade desse foro deliberativo. Tratase de um valor epistêmico remanescente que não pode ser ignorado. O parlamento tem, numa escala incomparável em relação à corte, capacidade de coletar informações, obter avaliações técnicas de todos os pontos de vista, considerar a multiplicidade de interesses em jogo, balancear interesses, fazer concessões e compromissos. Não está preso a uma lógica adversarial, e por isso lida com conflitos policêntricos de maneira mais eficaz. Considera os direitos fundamentais dentro da gama diversificada de ponderações necessárias de uma política pública. Isso não se confunde com "baratear direitos", mas consiste numa estratégia mais responsável e menos retórica e polarizada de tomar decisões coletivas.

\footnotetext{
${ }^{184}$ Citado por Urbinati, Representative Democracy, p. 3.

185 "It marks the end of a yes/no politics and the beginning of politics as open arena of contestable opinions and ever-revisable decisions". (Representative Democracy, p. 224)
} 


\subsection{5 “A objeção contra a supremacia do parlamento representativo ecoa preconceitos da tradição anti-democrática".}

Restrições ao parlamento insistem em resgatar, sub-repticiamente, os velhos medos anti-democráticos contra a ignorância e o despreparo das massas. Como lembrou Waldron, a revisão judicial não conseguirá proteger os direitos das minorias se não houver nenhum apoio a esses direitos na sociedade. Os defensores da revisão judicial não discordam disso, mas curiosamente acham que tal apoio virá de elites: "Eles defenderão isso como um dado empírico, mas preciso dizer que é inteiramente compatível com antigos preconceitos sobre a decisão democrática". ${ }^{186}$

\subsection{A favor da regra de maioria}

2.2.1 “A regra de maioria é o único princípio de decisão coletiva que respeita o imperativo moral da igualdade".

A decisão majoritária é tratada de modo passageiro por muitos textos clássicos da política. Para Waldron, esse pequeno esforço filosófico dispensado ao tema parece indicar que a regra de maioria sempre foi pensada e praticada como algo natural e intuitivo, que não precisaria de maiores fundamentações. Constrói sua teoria normativa da regra de maioria por meio da interpretação de uma passagem de Locke, segundo a qual a "maioria é mais forte". Waldron entende que tal força não pode ser lida na acepção física da expressão, mas na sua dimensão moral. O que mantém a comunidade integrada é o que chamou de "física do consentimento".

A regra de maioria é uma conquista porque permite que esse consentimento resulte da força moral da igualdade. Respeita indivíduos de duas maneiras: leva a sério diferenças de opinião e não os reprime por pensar diferente; e, fundamentalmente, trata-os como iguais. A acusação de arbitrariedade, nesse sentido, não percebe as razões pelas quais a legislação é uma fonte de direito digna de respeito: suas credenciais majoritárias permitem que cada participante tenha igual peso na decisão. ${ }^{187}$

\footnotetext{
186 "The core of the case against judicial review", p. 1405.

${ }^{187}$ Cf. The Dignity of Legislation, p. 151 e ss.
} 


\subsection{2 "A regra de maioria limita o poder".}

Segundo Ian Shapiro, ao contrário do que se pensa, a possibilidade dos "ciclos de votação", contrariamente aos receios gerados pelo diagnóstico de Arrow sobre a probabilidade de decisões arbitrárias, contribui para a estabilidade da democracia. Uma vez abandonada a expectativa de uma "vontade geral" ou de um "bem comum" racionalmente produzido por um método de decisão coletiva, pode-se perceber outra virtude no procedimento majoritário. ${ }^{188}$ Além disso, a história demonstraria que a probabilidade de uma "tirania da maioria" é menor em democracias do que em regimes não-democráticos, o que gera dúvidas plausíveis sobre o conhecido receio de Tocqueville. ${ }^{189}$

\subsection{3 "Decisões sobre questões de justiça não devem ser sensíveis à intensidade de preferências".}

A intensidade da preferência não diz nada sobre a sua justiça. $O$ fato de estarmos mais ou menos convictos, ou termos mais ou menos afeição por uma proposta, não tem absolutamente nenhum impacto na avaliação de sua correção. Quando direitos fundamentais estão em disputa, pouco interessa o quanto cada parte deseja determinado resultado. A legitimidade da decisão será testada por sua compatibilidade substantiva com o princípio de justiça. ${ }^{190}$

\section{Contra juízes e cortes}

A defesa da supremacia legislativa tem resposta, em alguma medida, a cada um dos argumentos favoráveis à revisão judicial. Distorcer, debilitar ou desnaturar são verbos que melhor expressam o tom dessa resposta. Esses argumentos não defendem propriamente a extinção da atividade jurisdicional em matéria de

\footnotetext{
${ }^{188}$ The State of Democratic Theory, p. 15-16.

${ }^{189}$ Ibid, p. 20.

${ }^{190}$ Essa é a conhecida resposta de Rawls: "To the contrary, whenever questions of justice are raised, we are not to go by the strength of feeling but must aim instead for the greater justice of the legal order. (...) Where issues of justice are involved, the intensity of desires should not be taken into account". ( $A$ Theory of Justice, p. 230-231)
} 
interpretação constitucional, mas não admitem que a construção do significado da constituição possa ser dominada pela corte.

\section{1 “A corte não protege as pré-condições da democracia, pois não está} fora da política".

A teoria constitucional teria engendrado uma operação conceitual rasteira, em duas partes. Primeiro, desqualifica como "meramente procedimental" o conceito de democracia que defende a prevalência do legislador na resolução de dilemas morais coletivos (geralmente traduzidos na linguagem dos direitos). Seria como se todo tipo de defesa da supremacia legislativa estivesse baseada numa visão amoral desse regime. ${ }^{191}$ Estaria apegada somente à forma e seria insensível à justiça (acusação semelhante à feita ao positivismo jurídico na teoria do direito). Seria um conflito entre os que levam direitos a sério e os que os desprezam. Segundo, tal operação teórica também constrói uma noção de cortes como agentes imunes ao conflito ideológico e que podem garantir respostas certas na proteção de direitos.

Em relação ao primeiro, confunde teoria da autoridade com teoria da justiça. Ou seja, mistura num mesmo argumento a pergunta "o que deve decidir" com "quem deve decidir”. É plenamente possível construir uma ambiciosa noção substantiva de democracia sem abrir mão de que o legislador tenha primazia na busca dessas metas. Negar a possibilidade de um controle externo ao parlamento jamais significou que o parlamento possa decidir o que bem entenda. Os riscos da política, ademais, não são eliminados por meio da corte. ${ }^{192}$

Em relação ao segundo, deve-se perceber que a corte não está fora da política e não é o agente neutro que às vezes se supõe. Especialmente quando se trata de interpretar a constituição, as posições são controversas e a opinião judicial não soluciona o desacordo. Apenas adiciona uma interpretação possível, mas com um custo para a democracia: essa opinião vem enfeitada com os adornos de uma linguagem aparentemente técnica, que esconde a manifestação de vontade e a

${ }^{191}$ Como exemplifica Waldron: "I am tired of hearing opponents of judicial review denigrated as being rights-skeptics. The best response is to erect the case against judicial review on the ground of a strong and pervasive commitment to rights". (Ibid, p. 1366)

${ }^{192}$ Waldron desenvolve esse argumento em Law and Disagreement. 
afirmação de agendas ideológicas. ${ }^{193}$ Faz parecer que o direito tem autonomia e que a corte atua num domínio puramente neutro. Essa visão açucarada das cortes cria uma conveniente imunidade de suas opiniões à contestação pública. Como afirmou Martin Shapiro: "O direito, aquele particularmente complexo, processual, o direito dos advogados, é uma arma maravilhosa quando se está perdendo no domínio menos esotérico da política". ${ }^{194}$

\section{2 "A corte não protege direitos das minorias: moralmente, isso é} controverso; empiricamente, isso é falso".

A linguagem da "tirania da maioria" encobre retoricamente um fenômeno mais complicado do ponto de vista moral. Não há nada necessariamente tirânico no fato de que uma minoria perca no parlamento, mesmo que com freqüência. Não se pode fazer essa acusação à maioria gratuitamente. Waldron, por exemplo, não nega a possibilidade da tirania da maioria, mas salienta a importância do refinamento analítico. A maioria pode estar certa. A minoria pode não ter o direito que ela pensa que tem. Pode haver um desacordo razoável e sincero entre pessoas que levam direitos a sério. Tirania da maioria não deve ser confundida, por isso, com qualquer situação de desacordo. É uma preocupação legítima somente quando as maiorias tópicas se alinham às maiorias decisórias. ${ }^{195} \mathrm{Se}$ isso for endêmico, trata-se, na tipologia de Waldron, de uma "situação atípica", especialmente quanto ao seu terceiro elemento (o compromisso de levar direitos a sério).

\footnotetext{
${ }^{193}$ Duas escolas da teoria jurídica americana são famosas por esse ataque à neutralidade da decisão judicial: o realismo jurídico, bastante influente nos anos 20 e 30, e os "estudos jurídicos críticos", dos anos 70 e 80 . Na ciência política, essa visão sobre adjudicação ecoou em estudos empíricos que assumem o juiz como ator ideológico, o que é mais evidente na corrente dos "attitudinal studies".

194 "Law, particularly complex, procedural, lawyers' law, is a wonderful weapon if one is losing in the less esoteric realms of politics". (“Apa: past, present and future”, p. 461)

${ }^{195}$ Essa é uma distinção importante de Waldron. Maioria ou minoria "tópica" corresponde ao grupo de pessoas que é atingido pela decisão (não ao que votou nela), seja por acréscimo ou decréscimo de direitos. A maioria ou minoria "decisória" se refere aos que votam para um ou para outro lado. Pessoas que levam direitos a sério tomam posição independentemente de se beneficiarem ou de se prejudicarem pessoalmente com a decisão. Somente quando uma minoria decisória coincide sistematicamente com a minoria tópica, para Waldron, há um sinal da real existência de uma minoria "insular e separada", que pode estar sofrendo a tirania da maioria. (Ibid, p. 1401)
} 
Em alguma medida, a tirania é inevitável. ${ }^{196}$ Ocorrerá sempre que decisões erradas sobre direitos forem tomadas. É um conceito substantivo, não procedimental. Independe do modo como a decisão é tomada, mas da decisão correta ou incorreta sobre direitos. Corte e parlamento podem atuar, igualmente, de modo tirânico. Isso não decorre do procedimento que adotam.

Do ponto de vista empírico, por sua vez, essa hipótese tampouco se sustenta, pois uma maioria consistente não demora a vencer. ${ }^{197} \mathrm{~A}$ corte não tem como resistir por muito tempo. Nesse intervalo, pode eventualmente submeter o regime a uma injustificável "tirania da minoria", por ser uma instituição elitista que persegue seus interesses. $^{198}$

Ao negar que o risco de tirania seja um bom argumento a favor da revisão judicial, não se subestima a importância dos direitos. Defende-se, apenas, que direitos serão melhor respeitados se cada cidadão efetivamente gozar do status de agente moral autônomo, com sua opinião contada igualmente nas decisões coletivas. Direitos continuam a ser a linguagem político-moral dominante, mas dentro de outra instituição mais compatível com o igual status dos cidadãos.

\section{3 “A corte não é emissária do poder constituinte nem mecanismo de} pré-comprometimento. Esse é um disfarce que encobre um agente político que faz escolhas morais controversas".

Recorrer à lógica do pré-comprometimento para justificar restrições à ação coletiva é uma manobra falaciosa. O povo, ao ter se comprometido a respeitar certos valores abstratos, não se posicionou sobre suas implicações concretas. Estas geram desacordos sinceros sobre os quais ele, povo, deve continuar decidindo. Os juízes não estão simplesmente respeitando as decisões constituintes originais. Estão tomando

\footnotetext{
196 "Democratic institutions will sometimes reach and enforce incorrect decisions about rights. This means they will sometimes act tyrannically. But the same is true of any decision process. Courts will sometimes act tyrannically as well. Tyranny, on the definition we are using, is more or less, inevitable. It is just a matter of how much tyranny there is likely to be". (Ibid, p. 1396)

${ }^{197}$ Robert Dahl, "The Supreme Court as a National Policy-Maker".

${ }^{198}$ Como diria Robert Bork: "Majority tyranny occurs if legislation invades the areas properly left to individual freedom. Minority tyranny occurs if the majority is prevented from ruling where its power is legitimate". ("Neutral Principles and Some First Amendments Problems", p. 8)
} 
suas próprias decisões sobre questões controversas, disfarçadas atrás da capa do poder constituinte.

Há também, por trás da idéia de dualismo constitucional, uma concepção indesejável de política: pressupõe que o cidadão somente manifesta virtude cívica e preocupação com o bem comum em poucos e rápidos momentos de sua vida. Uma democracia vibrante, no entanto, precisa da participação não apenas nos raros momentos constitucionais. $\mathrm{O}$ fato de a fundação constitucional ter sido democrática, ademais, não diz nada sobre o produto desse processo. Dito de outro modo, não se pode dizer que a revisão judicial é democrática porque um poder constituinte democrático a aprovou. Ele pode aprovar toda sorte de regime, dos mais aos menos democráticos. O fato de o "criador" ser formalmente democrático não significa que a “criatura” também o será.

3.4 “A corte, de fato, pode ter sua decisão rejeitada, ao final, pelo poder de emenda ou por uma nova constituição. Essa dificuldade, porém, não se justifica".

O poder de impor dificuldade tamanha é uma violação da igualdade pressuposta na regra de maioria. É um elemento anti-majoritário que enfraquece a responsabilidade do povo. Democracia não serve apenas para momentos de exceção. O povo não deve ser chamado a se manifestar somente por meio de válvulas de escape. Um regime de auto-governo pressupõe atividade política permanente. ${ }^{199}$

\section{5 “A revisão judicial não é decorrência necessária do estado de direito e} não deve ter exclusividade na interpretação da constituição. Interpretações do parlamento podem prevalecer".

É equivocada a inferência segundo a qual a constituição, para ser suprema, precisa, por imposição lógica, ser resguardada pela revisão judicial. Se assim o fosse, seria impossível admitir que leis inconstitucionais, com freqüência, sobrevivem e continuam obrigatórias seja em decorrência de seu não questionamento na corte, seja

\footnotetext{
199 Em minha dissertação, construí justificativa parecida para criticar o "paroxismo" da rigidez constitucional brasileira, que permite ao STF controlar, inclusive, a constitucionalidade de emendas constitucionais.
} 
em virtude do erro judicial. ${ }^{200}$ A qualidade normativa da constituição (e do direito em geral) é independente da existência de uma instituição que aplique sanções.

Se não é por necessidade lógica ou conceitual, pode ser que a revisão judicial seja desejável por conveniência prática, de modo a maximizar a eficácia do direito constitucional. Michelman, inclusive, admitiu que a revisão judicial, mais do que um corolário lógico do constitucionalismo, é apenas um "edifício de prudência política liberal". ${ }^{201}$ No entanto, essa tese superestima a capacidade de a corte produzir interpretações constitucionais melhores que as do parlamento. ${ }^{202}$

\section{6 “A corte não é um agente externo que julga com imparcialidade, pois} não está fora da política. Alguém precisa decidir por último, e nenhum dos possíveis candidatos a essa autoridade será neutro".

Não se deve obscurecer a lógica elementar da autoridade ${ }^{203}$ e confundir situações em que o juiz age como um terceiro não interessado (como em conflitos entre dois indivíduos, por exemplo), com o cenário muito mais conflituoso e impactante do controle de constitucionalidade. Nesse terreno, não há uma autoridade que esteja na condição de terceiro não interessado, que não possa julgar em causa própria. Os efeitos de suas decisões atingem a todos e o desacordo continuará a ser reinante. Portanto, melhor que tal autoridade seja o parlamento, tanto pelo valor moral que o alimenta, quanto por sua melhor capacidade de alcançar soluções mais balanceadas em face de temas irremediavelmente controversos. ${ }^{204}$ Vale, aqui, a mesma resposta contra o refrão da "tirania da maioria": numa sociedade que leva direitos a sério, mas que discorda sinceramente sobre sua aplicação, não há nada de necessariamente tirânico na maioria que desqualifique o parlamento e qualifique a corte.

\footnotetext{
${ }^{200}$ O que Nino chamou de "falácia de Marshall". (The Constitution of Deliberative Democracy, p. 192)

${ }^{201}$ Brennan and Democracy, p. 135.

${ }^{202}$ Whittington constrói uma resposta bastante elaborada contra a corrente crítica à possibilidade da interpretação extrajudicial, conforme descreveremos no capítulo 4.

${ }^{203}$ Esse argumento é rotineiro em Waldron: "Facile invocations of nemo iudex in sua causa are no excuse for forgetting the elementary logic of authority: people disagree and there is need for a final decision and a final decision-procedure". (Law and Disagreement, p. 297)

${ }^{204}$ Waldron novamente: "The need for settlement does not make the fact of disagreement evaporate; rather, it means that a common basis for action has to be forged in the heat of our disagreements". (“The core of the case against judicial review", p. 1370, 1371)
} 
3.7 “O controle de constitucionalidade não é mera decorrência da dinâmica da separação de poderes. Não há razão para que tenha a última palavra".

Não se nega a importância da separação de poderes. Há inúmeros outros elementos que moderam e contrabalanceiam a atividade legislativa. No entanto, há necessidade de que, ao final do jogo, alguma instituição tenha a última palavra para solução de dúvidas sobre a constituição. A possibilidade de que a corte revogue uma lei cria, ademais, dois efeitos perversos: distorce a política pública, que será desconfigurada pela interferência judicial e perderá a racionalidade original intentada pelo legislador; e debilita a democracia, pelas razões já expostas anteriormente. ${ }^{205}$

\section{8 "No controle de constitucionalidade, a corte não analisa exatamente} um caso concreto diferente dos casos concretos que informam a deliberação de uma lei".

Naquele argumento, há duas suposições equivocadas: que a corte tem sempre uma rica descrição concreta de um caso; que o legislador, ao deliberar, não está inspirado e não leva em consideração uma gama diversificada de casos reais. A corte freqüentemente estará menos informada que o parlamento. Este dispõe de inúmeros recursos para captar informações de variados grupos sociais, e tem melhor noção de impacto da lei pela experiência legislativa anterior (afinal, raros são os temas que, hoje, começam do zero sua história legislativa).

A corte não está em posição vantajosa e nem tem capacidade especial para saber se uma lei é constitucional ou não. Seria subverter uma escolha já feita pelo legislador. É claro que à ela continuará a função de desenvolver a lei e adaptá-la às circunstâncias concretas cambiantes. Mas isso não justifica que ela possa revogá-la, pura e simplesmente. Não se nega a necessária margem de construção interpretativa por parte da corte. A jurisprudência criativa é parte necessária da história de enraizamento de uma lei nas práticas sociais.

\footnotetext{
${ }^{205}$ Cf. Mark Tushnet, "Policy Distortion and Democratic Debilitation: Comparative Illumination of the Counter-Majoritarian Difficulty".
} 
Eventualmente, é verdade, pode ser que o legislador tenha mais dificuldades para enxergar a dimensão de direitos fundamentais numa lei que envolve considerações de muitos outros tipos. Para evitar essas potenciais miopias esporádicas, um modelo "fraco" de revisão judicial basta, pois ele será capaz de lançar luzes sobre o problema de constitucionalidade sem tirar do legislador o poder de revogar a lei. ${ }^{206}$

\section{9 "A corte é igualmente falível em questões de princípio e pessoas} discordam sobre a resposta correta".

A idéia de que a corte tem melhor capacidade para deliberar sobre princípios idealiza exageradamente o que de fato se passa ali. Esse argumento tem dois aspectos: um relacionado à expertise; outro ao ambiente institucional insulado das pressões eleitorais.

Quanto ao primeiro, não se pode delegar questões de princípio à expertise. São batalhas normativas e ideológicas, não ciências neutras e técnicas. As escolhas morais que a corte realiza não são mais qualificadas do que aquelas feitas por legisladores sinceros. Quanto ao segundo, em muitos sentidos, o insulamento pode ser justamente o problema, não a solução. ${ }^{207}$ Esse argumento ficará mais claro nos pontos abaixo.

\subsection{0 "A corte não promove uma representação deliberativa ou argumentativa. Juízes não representam, não são eleitos, e sim uma elite profissional".}

Aqui, a patologia da idealização da corte se torna mais acentuada. Não é necessário discordar da idéia de que a representação possa ser um fenômeno mais rico do que simplesmente sua modalidade eleitoral para recusar que a corte seja vista como a "representante da razão", em oposição ao "representante da agregação". A suposição da super-racionalidade judicial é uma obsessão dos teóricos normativos, mas já foi seguidamente desmistificada por diferentes correntes que, animadas pelo

\footnotetext{
${ }^{206} \mathrm{Cf}$. Waldron, "The core of the case against judicial review", p. 1370.

${ }^{207}$ Como afirmou Suntein: "From the moral point of view, insulation from majoritarian pressures is sometimes the problem, not the solution". ("Testing minimalism", p. 128)
} 
benefício da dúvida, deram mínima atenção a evidências empíricas. O ponto abaixo formula essa crítica com maior exatidão.

\subsection{1 “A corte não é instituição educativa, nem promove um debate público melhor do que o legislador. Está presa a uma linguagem empobrecida, verborrágica, inflexível e amarrada a tecnicalidades jurídicas".}

Há dois problemas na idéia de que a corte corresponderia a um padrão exemplar de razão pública. Em primeiro lugar, geralmente assume que o legislador não justifica suas decisões, tarefa que seria típica somente no judiciário. ${ }^{208} \mathrm{Em}$ segundo, vê na corte uma qualidade deliberativa que, ao menos segundo modelos desejáveis de discussão democrática de temas controvertidos, não existe.

Os padrões típicos da argumentação técnica judicial não convivem bem com a boa deliberação moral. A corte polariza e divide, não pacifica. Está presa a uma retórica adversarial, característica incurável da linguagem dos direitos. Suas rígidas declarações abstratas de princípio impedem o acordo e o compromisso. De suas decisões decorrem vencedores e perdedores. As partes do processo ou estão totalmente certas, ou totalmente erradas, sem concessões intermediárias. ${ }^{209}$ Não modera extremos nem acomoda posições em disputa. Despolitiza conflitos e, como conseqüência, desmobiliza e neutraliza movimentos de mudança. ${ }^{210}$

Para além do problema da rigidez, há também o da verborragia. Freqüentemente, a argumentação judicial tem um caráter legalista e hermético. Está mais preocupada com a semântica do que com os valores subjacentes, mais presa ao jargão do que ao argumento. A busca do significado verdadeiro de expressões escritas, que ganham vida própria, vira uma obsessão desconectada dos problemas reais que precisam resolver. Juízes estão enredados em camisas-de-força verbais. Escorregam para digressões e desvios irrelevantes. Dispersam-se em argumentos

208 Para Waldron, é possível captar grande qualidade argumentativa nos registros de debates parlamentares: "The difference is that lawyers are trained to close study of the reasons that judges give; they are not trained to close study of legislative reasoning". ("The core...", p. 1382)

${ }^{209}$ Cf. Rainer Knopff, "Courts Don’t Make Good Compromises”.

${ }^{210}$ Essa é a tese de Gerald Rosenberg que, ao contrário da grande celebração do caso Brown v. Board of Education, considera pequeno o papel da Suprema Corte americana no grande movimento da integração racial nos EUA durante a década de 60. (The Hollow Hope: Can Courts Bring About Social Change?) 
laterais sobre os cânones da argumentação jurídica, em vez de lidar com o dilema de fundo de modo franco e aberto. Em vez de deliberação moral com a qual o povo possa interagir, geram efeitos diversionistas.

Se tudo isso for verdade, a proposta de que ela possa cumprir uma função educativa e ensinar como argumentar sobre questões constitucionais essenciais não passa de mais uma fetichização engendrada pela teoria normativa. A decisão do caso Roe v. Wade é bom exemplo do efeito perverso de uma decisão judicial na deliberação pública. Tal decisão teria sufocado a política e bi-polarizado a sociedade americana num tema que vinha gradualmente recebendo soluções criativas por parte da legislação reguladora do aborto. Extraiu o tema do foro de negociação pública e o transformou numa questão rígida e binária de princípio. ${ }^{211}$ No texto da decisão, por sua vez, há páginas dedicadas à discussão sobre a aplicabilidade de precedentes, e apenas alguns parágrafos sobre a importância moral de direitos reprodutivos. ${ }^{212}$ Não contribuiu para que a sociedade percebesse os reais argumentos em jogo, e desviou o foco para legalismos moralmente irrelevantes.

\subsection{2 “A corte integra um sistema democrático, mas não deve ter a última} palavra".

A resposta aqui repete a mesma linda da observação acima sobre separação de poderes. Obviamente, a democracia não é um regime de "todos decidindo tudo todo o tempo". Há, de fato, uma intrincada rede de delegações e distribuição de funções. Porém, disso não decorre que não deva existir alguma hierarquização interna. Algumas decisões precisam ser dotadas de mais autoridade do que outras, e alguma instituição precisa ser a autoridade máxima. Mesmo que devamos pensar a legitimidade democrática do regime em bloco, há também que se considerar instituições mais e menos democráticas dentro desse bloco. É dessa análise que decorre a atribuição da última palavra ao legislador.

3.13 "A corte é composta por membros indicados por autoridades eleitas, mas este mecanismo não é suficiente para a prestação de contas democrática".

\footnotetext{
${ }^{211}$ Cf. Cass Sunstein, One Case at a Time, p. 36, e Mary Ann Glendon, Rights Talk, p. 58.

${ }^{212}$ Waldron, "The core of the case against judicial review", p. 1381.
} 
Mesmo que esse mecanismo confira, de fato, alguma conexão dos juízes com as autoridades eleitas, do ponto de vista comparativo, não há como justificar que a corte prevaleça sobre o legislador. Não basta uma remota semente democrática. Legitimidade se mede pela comparação: é preciso demonstrar que a autoridade dotada da última palavra é mais democrática que as alternativas, e essa hipótese não se adapta ao caso.

\section{Quem e como e quando e por que decide sobre direitos numa democracia constitucional?}

Parlamentos devem decidir por último sobre direitos pela mescla de razões morais e instrumentais esboçadas acima. Do ponto de vista moral, o parlamento é uma instituição valiosa tanto por representar o povo (e potencializar a dinâmica deliberativa que o distanciamento representativo permite), quanto por ver em cada indivíduo igual importância. Num contexto de desacordo, todos devem ter a igual possibilidade de participar do processo de resolução, em vez de delegar a uma elite. Democracia, de fato, tem pré-condições, mas elas não se realizam senão pela estratégia institucional de representação e da regra de maioria.

Para além das razões de legitimidade, há também uma capacidade institucional vantajosa do parlamento. Permite que a linguagem dos direitos seja desenvolvida de um modo menos técnico e hermético e que os dilemas morais sejam enfrentados na sua substância, não por obsessões semânticas.

\section{Os cenários desbalanceados dos capítulos 2 e 3 e preâmbulo do capítulo 4}

Num cenário, um legislador predominantemente egoísta e venal, dedicado exclusivamente ao alpinismo político, à expansão e perpetuação de seu poder, contra um heróico e impassível juiz defensor de direitos, líder do debate moral, e consciência crítica e educadora da democracia. No outro, um juiz verborrágico, legalista e ideológico contra um legislador virtuoso e de espírito público. 
É possível acomodar as críticas ao legislador e os elogios ao juiz (cap. 2), junto com as críticas ao juiz e os elogios ao legislador (cap. 3)? São faces possíveis da mesma moeda? Uma teoria está condenada ao ônus da escolha entre as versões degeneradas e idealistas de juiz e legislador?

Teorias do diálogo, como se verá no próximo capítulo, são também variadas, mas lidam melhor com essas duas faces à medida que se mostram menos preocupadas com a última palavra. Na sua versão mais elaborada, a perspectiva do diálogo provavelmente faz isso: aceita a falibilidade das duas instituições e a combina com um ambicioso projeto normativo que leve em conta as vantagens comparativas das duas, uma vez que não são mais necessariamente excludentes. Diversos dos argumentos expostos nos capítulos 2 e 3 reaparecerão, implícita ou explicitamente, no capítulo 4. A estrutura de exposição, porém, muda para considerar em maior detalhe autores específicos que dão alguma contribuição particular ao debate. 


\section{Capítulo 4}

\section{A inclinação por ambos: diálogo sem última palavra}

\section{Introdução}

Diálogo é uma imagem fecunda e expressiva para a política. É signo de igualdade, respeito mútuo e reciprocidade. Denota uma relação horizontal e não hierárquica. Carrega, portanto, um valor sedutor para justificar decisões de autoridade. Indivíduos dialogam em ambientes formais e informais da política. No interior das instituições, decisões não costumam ser tomadas sem uma prática mínima de diálogo. Podem instituições dialogarem entre si?

Esse capítulo aborda teorias que aceitam, em alguma medida, tal hipótese. Trata-se, claro, de um tipo menos visível dessa prática. Não reproduz, à perfeição, o que costumamos pensar como diálogo. Requer alguma abstração para sustentar que as interações entre as instituições são dessa natureza. A separação de poderes é o pano de fundo dessas teorias, cujo desafio é mostrar que tal imagem traz algo de novo para a forma como esse mecanismo básico do constitucionalismo é concebido. Não se deve cobrar dessas teorias a demonstração de que as instituições estão conversando amistosa e pacificamente umas com as outras, mas ao menos uma abordagem original.

A relação específica para a qual o capítulo se dirige é a estabelecida entre parlamentos representativos e cortes constitucionais. ${ }^{213}$ Teorias do diálogo, em geral, contrariamente às apresentadas nos capítulos 2 e 3, não fazem grandes demandas normativas sobre o tipo ideal de legislador ou de juiz. Estão preocupadas em entender o significado de sua interação. Apresentam uma forma nova de olhar e entender a revisão judicial e o processo legislativo, vítimas de desconfiança por parte das teorias da última palavra. Essa mudança de perspectiva pretende produzir impacto relevante ao defender que a decisão da corte não é, e não tem como ser, o fim da linha.

\footnotetext{
${ }^{213}$ Uma abordagem integral da separação de poderes através da perspectiva dialógica requereria também a análise de como o executivo participa nesse processo. Este trabalho, porém, concentra-se numa versão incompleta de uma teoria mais ampla. Esse foco restrito à relação entre parlamentos e cortes é a opção tradicional da teoria constitucional e tem uma razão de ser: o poder executivo nunca foi considerado um candidato para a última palavra em questões de direitos fundamentais.
} 
As sementes da idéia de que há uma interlocução institucional que deve ser incorporada à justificativa da revisão judicial já apareciam na dissertação. A metáfora existe na literatura americana há bastante tempo. Bickel, na década de 60 , já falava em "colóquio contínuo" (continuing colloquy) e em "conversa permanente" (permanent conversation). ${ }^{214}$ Louis Fisher, em publicações das décadas de 70 e 80, já se referia a " diálogos constitutionais". Bruce Ackerman considera essa imagem para pensar a separação de poderes americana, principalmente pela idéia de "dualismo constitucional" (a variação entre momentos de "política normal" e de "política constitucional").

Teorias do diálogo, com nuances variadas, procuraram amenizar a preocupação com a "dificuldade contra-majoritária", nos termos de Bickel. Aquela imagem, também inaugurada pelo mesmo autor, não foi tão bem sucedida quanto esta expressão que o celebrizou, mas vem renascendo e impregnando o debate americano nos últimos 20 anos. Teorias do diálogo tentam escapar da armadilha da última palavra e defendem uma atitude teórica que rompa essa camisa-de-força. Propõem-se como uma "terceira via", um meio-termo. ${ }^{215}$ A defesa desse prisma é feita por uma literatura multifacetada, composta por um grande número de autores.

Além das nuances e versões das diferentes teorias do diálogo, deve-se perceber o que elas têm em comum e como contrastam com teorias da última palavra. Dois são os seus principais denominadores comuns: a recusa da visão juricêntrica e do monopólio judicial na interpretação da constituição, a qual é e deve ser legitimamente

\footnotetext{
214 "Virtually all important decisions of the Supreme Court are the beginnings of conversations between the Court and the people and their representatives. They are never, at the start, conversations between equals. The Court has the edge... [but] the effectiveness of the judgment universalized depends on consent and administration". (The Supreme Court and the Idea of Progress, p. 91). "The Court interacts with other institutions, with whom it is engaged in an endlessly renewed educational conversation... And it is conversation, not a monologue". (The Morality of Consent, p. 111)

215 Kent Roach reconhece que, por ocupar um espaço intermediário, a teoria do diálogo é inevitavelmente atacada pelos defensores da supremacia judicial, em virtude do excessivo espaço que concederia ao legislador, e vice-versa: "If so, an interesting feature of dialogue theory is that it may occupy the middle ground between those who are suspicious of courts and rights protection and those who are passionate defenders of courts and rights protection. Dialogue theory is criticized both for defending judicial review and for allowing legislature to override rights. There is often much wisdom in middle-ground or half-way positions. Alas, however, you can end up being shot at by both sides!" ("Sharpening the Dialogue Debate", p. 177; cf. também Roach em The Supreme Court on Trial, p. 292) A estratégia expositiva, adotada também por essa tese, de apresentar duas posições polarizadas e tentar conciliá-las por uma terceira, já foi adotada por outros autores. Cf., p. ex., Janet Hiebert, em Charter Conflicts: What is Parliament's Role?, onde concebe um regime de "responsabilidades compartilhadas" entre cortes e parlamentos, contra a deferência judicial recomendada por uma posição originalista ou a imponência judicial decorrente de uma concepção substantiva da revisão judicial.
} 
exercida pelos outros poderes; a rejeição da existência de uma última palavra, ou, pelo menos, de que a corte a detenha por meio da revisão judicial.

Dividem-se em duas categorias gerais. ${ }^{216}$ A primeira propõe uma teoria da decisão judicial que leve em conta a interação com o legislador. Não se trata propriamente de um método de interpretação, mas de uma demanda de que a corte reconheça e participe do diálogo. É uma forma de compreensão normativa do seu papel. A segunda define o diálogo como produto necessário da separação de poderes, uma decorrência do desenho institucional, não necessariamente da disposição de qualquer dos poderes por “dialogar”. Nessa categoria, teorias são predominantemente empíricas, mas a fronteira entre argumentos positivos e normativos torna-se gradualmente nebulosa. Com freqüência, proposições descritivas influenciam o próprio comportamento das instituições que participam do diálogo, o qual passa a ser uma razão invocada para a escolha decisória, como se verá no caso canadense.

A primeira, portanto, tem um caráter endógeno e a segunda aponta para o fenômeno exógeno, menos dependente da postura de cada instituição. Os argumentos dos últimos dois capítulos não saem de cena, mas ganham novo peso e lugar na cadeia argumentativa. O capítulo sistematiza essas duas categorias, indicando os principais autores dentro de cada uma. Em seguida faz sínteses conclusivas que fecham, junto com os últimos dois capítulos, o bloco descritivo da tese. O critério de seleção de cada autor e cada corrente foi a adição de algo novo ao debate. Mesmo que, com freqüência, esses autores se repitam em diversos pontos, acredito que haja aspectos particulares a serem ressaltados em cada um.

\section{Diálogo no interior da decisão judicial}

\footnotetext{
${ }^{216}$ Essa divisão entre duas categorias gerais guarda semelhança com a classificação feita por Christine Bateup em texto bastante útil para uma revisão bibliográfica ("The Dialogic Promise”). Não sigo precisamente essa autora nas outras subdivisões que realiza dentro dessas categorias e tampouco suas conclusões. Ela apresenta tais teorias numa seqüência linear das piores para as melhores, defendendo que a melhor teoria do diálogo deve surgir da combinação das perspectivas de Janet Hiebert (que ilumina a interação horizontal entre as instituições) e de Barry Friedman (que destaca o diálogo mais amplo com a sociedade e o papel da opinião pública). Procuro encontrar maior complementaridade entre teorias que ela apresenta de forma excludente.
} 
A tensão básica entre os autores que defendem uma decisão judicial sensível ao diálogo é de grau: alguns preferem atuações deferentes, passivas e minimalistas; outros uma intervenção ativa e maximalista. Essas abordagens chamam atenção para a complexidade da decisão em controle de constitucionalidade. Esta não se restringe a uma escolha binária entre o constitucional e o inconstitucional. Mesmo que, do ponto de vista formal, essas decisões tenham que se posicionar em um dos dois lados, há diferentes intensidades pelas quais fazê-lo. Essas decisões dão sinalizações ao legislador e fazem, mais do que uma estrita interpretação jurídica, um juízo de ocasião sobre até onde a corte pode e deve interferir no respectivo caso.

\subsection{Virtudes passivas}

\subsubsection{Alexander Bickel, virtudes passivas e colóquio socrático: a corte como animal político prudente}

Alexander Bickel é um autor que ocupa posição curiosa na teoria constitucional contemporânea. Pode-se dizer que, em grande medida, formulou a agenda da geração que o sucedeu. No entanto, se as questões que levantou e as expressões que cunhou tiveram, por um lado, grande impacto, suas respostas não exerceram tanta influência. Entre suas expressões, a mais célebre delas foi a "dificuldade contra-majoritária", referência de primeira página de todos os livros que discutiram o assunto desde então. ${ }^{217}$

A leitura de sua obra enfrenta algumas dificuldades. Nela não há elaboração de fôlego de um argumento, uma seqüência sistemática de uma idéia. Entremeia pinceladas teóricas instigantes com muitas análises de casos e passagens constitucionais da história americana. É um autor que se destaca pela eloqüência de algumas de suas frases, pelas suas provocações inspiradoras e por ter iluminado perspectivas férteis e originais para lidar com o problema. ${ }^{218}$ Derivar de seus textos uma teoria constitucional bem articulada, portanto, é um desafio de interpretação.

\footnotetext{
${ }^{217}$ Para Bickel, a revisão judicial obviamente representava uma desconfiança do legislador e das maiorias: "The root difficulty is that judicial review is a counter-majoritarian force in our system. (...) That, without mystic overtones, is what actually happens. It is an altogether different kettle of fish, and it is the reason the charge can be made that judicial review is undemocratic. (...) nothing in these complexities can alter the essential reality that judicial review is a deviant institution in the American democracy". (The Least Dangerous Branch, p. 16-18)

${ }^{218}$ Suas frases mais importantes estarão transcritas em notas de rodapé durante o capítulo.
} 
Todavia, é também um exercício necessário para demonstrar que seu legado não se resume a um conjunto de slogans.

Sua obra foi construída no calor das agitações da década de 60, momento turbulento da sociedade americana. A Suprema Corte teria assumido, naquele momento, papel de protagonista na condução das transformações sociais, relacionadas sobretudo a casos de segregação racial. Intrigava a Bickel encontrar uma justificativa para o ativismo que a corte vinha exercendo dentro da democracia. ${ }^{219}$ Ao mesmo tempo, pelo caráter contra-majoritário da corte, queria entender como sobreviveu no período.

Sua forma de abordar essas questões reúne passagens enigmáticas e inconclusivas, talvez pelos conceitos atípicos e inovadores que ele insere na reflexão sobre adjudicação constitucional. Virtudes passivas, colóquio socrático, arte do compromisso, prudência, longo prazo, gradualismo, pragmatismo, acomodação, estabilidade, entre outras, são palavras que geram certa perplexidade para quem está acostumado a entender o papel da corte à luz da prática de interpretação constitucional e da proteção dos direitos.

Bickel ajuda a perceber que há mais no controle de constitucionalidade do que interpretação e aplicação do direito. Essa não é, propriamente, uma novidade, pois o realismo jurídico e as vertentes da ciência política que investigaram o judiciário sempre desacreditaram dessa premissa. A perspectiva de Bickel é inovadora, contudo, porque defende as virtudes políticas da corte e as insere numa teoria normativa da revisão judicial. Não se trata apenas de dizer que é inevitável a corte ser influenciada por fatores externos ao direito, mas de sustentar que é assim que deve ser, a depender de quais forem esses fatores. Esse é o argumento de Bickel que se conecta com a idéia do diálogo, e passo a abordá-lo com mais detalhe.

Juízo político é tabu na teoria constitucional normativa. Dificilmente alguém o admite com total clareza. Quando se desconfia de algum traço discricionário na decisão, o objetivo é censurá-lo, evitá-lo, controlá-lo (ou, eventualmente, escondê-lo).

\footnotetext{
${ }^{219}$ Uma justificativa que superasse as explicações de Marshall, em Marbury v. Madison, de James Thayer, de Learned Hand e de Herbert Wechsler, autores abordados no capítulo 2 do livro.
} 
O juízo político que Bickel tem em mente, porém, não é associado ao impulso, ao sentimento, à predileção ideológica. Continua a ser informado por uma vontade desinteressada e isenta. Consiste num juízo qualificado pela virtude da prudência e é, sobretudo no exercício da prudência, que a corte se comporta como "animal político". 220

Para Bickel, em toda decisão política, inescapavelmente, há duas dimensões: a de princípio e a de conveniência e oportunidade (expediency). ${ }^{221222}$ Em todo ato de governo, podem-se observar dois aspectos: o seu efeito concreto imediato e a sua relação com os valores duradouros que dão coesão e unidade à comunidade política. O gerenciamento da tensão entre ambos é a essência da arte de governo, e isso se aplica tanto ao juiz quanto ao legislador, ainda que em doses diferentes. Esse era o argumento da filosofia política de Lincoln, donde Bickel denominá-la de "tensão lincolniana". ${ }^{223}$ A corte, e também os outros poderes, estão imersos nessa tensão, e não se pode tentar eliminá-la ou dissimulá-la. ${ }^{224}$

Não há grande precisão, como tampouco em outras noções de Bickel, na definição de princípio. ${ }^{225}$ Refere-se à enunciação dos valores que regulam a política e as relações sociais numa sociedade. Entende-se melhor o seu significado pelo contraste com a noção de conveniência e oportunidade. Esta implica no exercício do

\footnotetext{
${ }^{220}$ Essa expressão, assim como várias outras passagens do seu livro mais famoso, The Least Dangerous Branch, aparecem num artigo anterior, em que já apresenta suas primeiras idéias: "Foreword: The Passive Virtues". Após defender o uso de certas técnicas de "não decisão", Bickel conclui: "They mark the point at which the Court gives the electoral institutions their head and itself stays out of politics, and there is nothing paradoxical in finding that here the Court is most a political animal. But this is not to concede judgment proceeding from impulse, hunch, sentiment, predilection, inarticulable and unreasoned. The antithesis of principle in an institution that represents decency and reason is not whim, nor even expediency, but prudence" (p. 51 do artigo, p. 132 do livro).

221 "No good society can be unprincipled; and no viable society can be principle-ridden. But it is not true in our society that we are generally governed wholly by principle in some matters and indulge a rule of expediency exclusively in others. There is no such neat dividing line. (...) both requirements exist most imperatively side by side: guiding principle and expedient compromise" (The Least Dangerous Branch, p. 63-64).

${ }^{222}$ Essa distinção não se confunde com a de Ronald Dworkin, entre princípios e políticas públicas, apesar de algumas relações óbvias poderem ser traçadas.

${ }_{223}$ "Our democratic system of government exists in this Lincolnian tension between principle and expediency, and within it judicial review must play its role". (The Least Dangerous Branch, p. 68, ou "Foreword: The Passive Virtues", p. 49)

${ }^{224}$ A tentativa de Wechsler de restringir o papel da corte à busca dos "princípios neutros" seria, para Bickel, uma grande distorção: "No attempt to lift the Court out of the Lincolnian tension can be successful". (The Least Dangerous Branch, p. 131)

225 "Principle, ethics, morality - these are evocative, not definitional, terms; they are attempts to enclose meaning, not to enclose it" (The Least Dangerous Branch, p. 199).
} 
compromisso, da faculdade pragmática de perceber o que é factível. O princípio, ao contrário, denota um valor moral rígido, que não faz concessões. O agente decisório precisa ser dotado de uma sensibilidade especial para saber balancear as demandas de princípio com a necessidade de acomodação estável à realidade. Não pode apegar-se à ambição de mudança abrupta do princípio. Há de ter flexibilidade para conduzir mudanças graduais e estáveis.

A missão principal da corte, da qual decorre a justificativa de sua autoridade, é defender a dimensão de princípio. ${ }^{226}$ Essa é sua capacidade institucional singular, difícil de ser encontrada no parlamento representativo. ${ }^{227}$ Para a promoção do princípio, são necessários hábitos mentais e costumes institucionais que a corte tem maior probabilidade de desenvolver. ${ }^{228}$ Além disso, ela também tem a vantagem de lidar com casos concretos, que fornecem um teste saudável para as abstrações valorativas. Se o parlamento não está bem equipado para essa tarefa, é natural que à corte caiba a missão de guardar e pronunciar tais princípios. ${ }^{229}$ No entanto, Bickel se põe uma pergunta: “como a corte, encarregada da função de enunciar princípios, produz ou permite os necessários compromissos?" ${ }^{230}$ Como evitar que seja forçada a impor sobre a sociedade, repentinamente, regras rígidas que vão contra as práticas enraizadas?

A corte, diante de um caso, tem à sua disposição três alternativas. Em primeiro lugar, tem o poder de revogar uma lei por inconstitucionalidade. Em segundo lugar, pode validar e legitimar essa lei, se entendê-la constitucional. ${ }^{231}$ Tanto uma quanto outra precisam ser tomadas com base em princípios. São as duas escolhas óbvias que um tribunal pode fazer quando analisa o mérito da disputa constitucional. Há, no entanto, uma terceira opção: a corte pode não fazer nenhuma das duas coisas, e

\footnotetext{
226 "the role of the Court and its raison d'être are to evolve, to defend and to protect principle" (The Least Dangerous Branch, p. 187-188, ou "Foreword: The Passive Virtues", p. 77)

${ }^{227}$ [In legislative assemblies] "men will ordinarily prefer to act on expediency rather than take the long view. [Our system calls for] evolution of principle in novel circumstances, rather than only for its mechanical application. (...) the creative establishment and renewal of a coherent body of principled rules - that is what our legislatures have proven themselves ill equipped to give us. (...) courts have certain capacity for dealing with matters of principle that legislatures and executives do not possess". (The Least Dangerous Branch, p. 25)

228 "Their insulation and the marvelous mystery of time give courts the capacity to appeal to men's better natures". (Ibid, p. 24).

${ }^{229}$ Ibid, p. 24.

${ }^{230}$ Ibid, p. 69.

${ }^{231}$ O que Bickel chamou de "função mística", do efeito simbólico (Ibid, p. 29).
} 
decidir não decidir. Para tanto, lança mão de uma série de "técnicas de não decisão", as chamadas virtudes passivas. São ferramentas processuais por meio das quais a corte evita emitir sua opinião sobre o caso, pois ela não pode estar obrigada a legitimar tudo aquilo que não considere inconstitucional. ${ }^{232}$ Em face de dois extremos, abre uma saída pelo meio, um mecanismo para aplicar a máxima do juiz Brandeis: "a coisa mais importante que fazemos é não fazer". 233

A corte precisa ter, por isso, sensibilidade para o exercício dessa tarefa mais sutil de não decidir, de saber se, quando e quanto decidir, perguntas inadmissíveis para concepções rígidas da revisão judicial. Há, segundo o autor, uma diferença de tipo, e não de grau, entre a interpretação do direito e o uso de virtudes passivas, estas mais ligadas à prudência. ${ }^{234} \mathrm{O}$ princípio é a antítese da prudência, o que não significa que esta não tenha um significado racional. ${ }^{235}$ A revisão judicial pode jogar, nas palavras do autor, com o "maravilhoso mistério do tempo" e esperar. Esse tempo de espera é valioso para que processos deliberativos sejam estimulados na sociedade, antes que se tome uma decisão rígida de princípio. Deixa-se a questão de princípio amadurecendo e sendo testada pela experiência.

A corte, ainda, segundo Bickel, deve tentar persuadir antes de coagir, encontrar uma acomodação tolerável entre as demandas do princípio e de conveniência. ${ }^{236}$ Se seguir o rumo contrário à opinião pública, ao longo do tempo, sua

\footnotetext{
${ }^{232}$ As virtudes passivas específicas a que Bickel se refere correspondem a uma série de doutrinas sobre justiciabilidade que a Suprema Corte usa para evitar ter que decidir o mérito do caso. Entre elas: political question doctrine, mootnes, ripeness, standing, certiorari etc. São instrumentos técnicos típicos do processo americano, que eventualmente encontram equivalentes em outros sistemas.

${ }^{233}$ Ibid, p. 69.

234 "It is different, just so; but only by means of a play on words can the broad discretion that the courts have in fact exercised be turned into an act of constitutional interpretation. The political-question doctrine simply resists being domesticated in this fashion. There is something different about it, in kind, not in degree, from the general 'interpretive process'; something gently more flexible, something of prudence, not construction and not principle. And it is something that cannot exist within the four corners of Marbury v. Madison". ("Foreword: The Passive Virtues", p. 46).

235 "The passive devices that I have canvassed do not produce constitutional decisions. They do not check or legitimate on principle. They are not themselves principled, they do not operate independently, and the variables that render them decisive cannot be contained in any principle; (...) But the passive devices have intrinsic, rational significance. The Court's authority to employ them is derived from its ultimate function of rendering principled adjudications; for this is a function that can be wisely and fruitfully exercised only if the Court is empowered also to decide whether and when to exercise it. The presence in the case of the ultimate issue of constitutional principle is the source of the Court's authority to make a lesser decision (...)”. (The Least Dangerous Branch, p. 205).

236 "And the Court's arguments need not be compulsory in order to be compelling. Many of the devices of not doing engage the Court, as I have shown, in colloquies with the political institutions" (Ibid, p. 188).
} 
autoridade ruirá. ${ }^{237}$ Em algumas circunstâncias, não seria sábio interferir no processo democrático por meio de um julgamento rígido de princípio. ${ }^{238}$ A obrigação de decidir todo o tempo levaria a um processo manipulativo da democracia, ou então, provavelmente, ao abandono do princípio, o que faria a corte simplesmente substituir o julgamento de conveniência do legislador (e a tornaria um second guesser $^{239}$ ). As virtudes passivas, assim, "toleram desvios do princípio" em nome de uma acomodação estável das mudanças sociais. ${ }^{240}$

Essa é, para Bickel, a missão educativa da corte, instituição que cumpre o papel de "professor da cidadania" (teacher of the citizenry $\left.{ }^{241}\right){ }^{242}$ Ao evitar decidir, a corte estimula um colóquio $\left(\right.$ colloquy $\left.^{243}\right)$ com os outros poderes e a sociedade. ${ }^{244}$ Mantém-se dentro da tensão entre princípio e conveniência, modera extremos e previne que a sociedade se divida. ${ }^{245}$ Esse colóquio tende a gerar uma pressão por ação legislativa que, não raro, é mais efetiva que uma ordem judicial inflexível, nos moldes de um decreto. ${ }^{246}$ A decisão deve ser a exceção; o exercício de virtudes passivas, a regra, um meio termo entre o judicialismo autoritário e a democracia. ${ }^{247} \mathrm{~A}$ corte deve ter sabedoria para deixar o colóquio decantar novos valores, e decidir somente quando a solução pareça uma decorrência natural desse processo. ${ }^{248} \mathrm{O}$ ${ }^{237}$ Ibid, p. 28.
${ }^{238}$ Ibid, p. 206.
${ }^{239}$ Ibid, p. 200.
${ }^{240}$ Ibid, p. 232.
${ }^{241}$ Ibid, p. 188.

${ }^{242}$ Usando as palavras de Dean Rostow, Bickel destaca o papel da corte como "teachers in a vital national seminar". E continua: "And such a seminar can do a great deal to keep our society from becoming so riven that no court will be able to save it". (Ibid, p. 24)

${ }^{243}$ Esse é um termo constante no argumento de Bickel, e daí sua clara referência às teorias do diálogo. Cf., p. ex., pp. 70, 143, 179, 180, 187, 196, 216, 231.

244 "When the Court, however, stays its hand, and makes clear that it is staying its hand and not legitimating it, then the political processes are given relatively free play. Such a decision needs relatively little justification in terms of consistency with democratic theory. (...) [The Court has developed an arsenal of] techniques for eliciting answers, since so often they engage the Court in a Socratic colloquy with the other institutions of government and with society as a whole. (...) All the while, the issue of principle remains in abeyance and ripens" (Ibid, p. 70-71).

245 "It may do neither, and therein lies the secret of its ability to maintain itself in the tension between principle and expediency". (Ibid, p. 69).

${ }^{246}$ Ibid, p. 196.

${ }^{247}$ Ibid, p. 244.

248 "The first wisdom, (...), is that the moment of ultimate judgment need not come either suddenly or haphazardly. Its timing and circumstances can be controlled. (...) Over time, as a problem is lived with, the Court does not work in isolation to divine the answer that is right. It has the means to elicit partial answers and reactions from the other institutions, and to try tentative answers itself. When at last the Court decides (...), the answer is likely to be a proposition 'to which widespread acceptance may fairly be attributed', because in the course of a continuing colloquy with the political institutions and with the society at large, the Court has shaped and reduced the question, and because it has rendered the answer familiar, if not obvious" (Ibid, p. 240) 
princípio, nesse sentido, é um guia valorativo que se desenvolve pelo diálogo, não pela imposição unilateral. ${ }^{249}$ Por meio dele, a corte abre a oportunidade da "reprise legislativa". 250

Compromissos pragmáticos que não alcançam a meta ótima do princípio podem ser necessários por um tempo. Fazê-los não reduz a efetividade dos princípios, mas apenas reconhece o grau de sua factibilidade num dado momento. ${ }^{251}$ As virtudes passivas deixam espaço aberto para isso. Como a corte somente pode decidir com base em princípio (para que seja vinculante e dotada de autoridade), a maneira de possibilitar soluções de compromissos é não decidir. Escapa da armadilha binária da obrigação de invalidar uma lei ou legitimá-la. ${ }^{252}$ Equilibra-se numa zona intermediária. Usa de uma válvula de escape para driblar a obrigação de decidir com base em princípio. ${ }^{253}$ Pratica uma sabedoria institucional ao deixar não decidido, e viabiliza um gradual exercício de "tentativa e erro". ${ }^{254}$

A corte permite que questões sejam postas no debate público, e prefere não respondê-las, exceto em circunstâncias excepcionais. Se a regra é deixar não decidido, qual o critério para saber quando, enfim, decidir? Essa é uma chave fundamental do argumento. Para Bickel, esse momento se determina por três critérios alternativos: quando a corte tem expertise especial no assunto; quando há informação e conhecimento confiável; quando seu senso político diz que é necessário. ${ }^{255}$ Somente deve decidir quando esgotados os recursos de promoção do diálogo, quando houver clara necessidade. ${ }^{256}$ Precisa adivinhar os princípios que, no futuro não distante,

\footnotetext{
249 "Principle may be an universal guide, not an universal constraint, that leeway is provided to expediency along the path to, and alongside the path of, principle, and, finally, that principle is evolved conversationally nor perfected unilaterally" (Ibid, p. 244.)

${ }^{250} \mathrm{Ibid}$, pp. 217, 221, 223, 230.

251 "The effectiveness of principle is not less because we are allowed to admit that we do not live up to it when we don't". (Ibid, p. 96).

252 "This is not to say that the Supreme Court should legitimate them - only that it should leave their constitutionality undecided". (Ibid, p. 72)

253 "More typically, the passive devices of the colloquy precede, and prepare or avoid, the moment of constitutional judgment" (Ibid, p. 254).

${ }^{254}$ Ibid, p. 192.

255 "The answer cannot be, across the board, yes, we have no principles; let expediency rule (...) It can only be, yes, in contravention of principle, if necessary (...); The judgment of necessity is prudential. The Court sometimes makes bold to undertake for itself and to cause principle to prevail, usually when subject matter is well within its experience, as in the administration of criminal law, or when its own political sense (which can be treacherous) tells it that the necessity has abated, or when it can draw on some fairly stable body of knowledge to disprove the necessity. Otherwise the Court is capable of only tentative estimate" (The Least Dangerous Branch, p. 187, ou "Foreword: The Passive Virtues", p. 77). ${ }^{256}$ Ibid, p. 189.
} 
ganharão assentimento social. ${ }^{257}$ Faz um juízo prospectivo. Tem a obrigação de, em alguma medida, acertar, sob pena de cair em descrédito.

Não se trata de um critério formal, quantificável e calculável a priori, mas de um faro político, de um senso de oportunidade histórica, um radar para captar o estado de espírito da comunidade. A corte, nessas situações, está no terreno intangível do juízo de ocasião e de medida, do exercício da prudência. Bickel reconhece a dificuldade de expressar esse conceito, dado seu caráter escorregadio. É uma sabedoria prática, uma capacidade de reconhecer o momento certo segundo o caso particular. ${ }^{258}$ Diante dessa dificuldade, usando as palavras do juiz Frankfurter, Bickel compara tal habilidade à do artista, que precisa de um sensor que registre sentimentos para além de provas lógicas e quantitativas. A corte opera como um profeta, um líder de opinião que aponta para o futuro. Não é apenas alguém que espelha e registra as opiniões presentes. ${ }^{259}$

Quando, enfim, escolhe decidir, deve também verificar o quanto, mais uma escolha orientada pelo critério da necessidade. Há decisões mais interventivas que outras e é preciso saber calcular a extensão da decisão a cada momento, de acordo com o "continuum do poder judicial". ${ }^{260}$ Os movimentos da corte não devem ser repentinos e bruscos, mas cautelosos, em pequena escala. ${ }^{261}$

Tudo isso ecoa, certamente, o espírito conservador de Edmund Burke, e Bickel reconhece explicitamente essa fonte em outro livro que publicou anos mais tarde. ${ }^{262}$ Ali, desenvolve um pouco melhor a conciliação entre sua inclinação conservadora e

\footnotetext{
257 "What is meant, rather, is that the Court should declare as law only such principles as will - in time, but in a rather immediate foreseeable future - gain general assent" (Ibid, p. 239).

258 "In one sense, we have thus got no nearer to parsing the inexpressible" (Ibid, p. *).

259 "The Court is a leader of opinion, not a mere register of it, but it must lead opinion, not merely impose its own; and - the short of it is - it labors under the obligation to succeed. (...) the Court must pronounce only those principles which can gain 'widespread acceptance', that it is at once shaper and prophet of the opinion that will prevail and endure. To be sure, there is still not much help in 'quantitative proof'; it is still a question of 'antennae"'. (Ibid, p. 239)

260 "not all constitutional decisions have the same weight, the same reach, the same binding quality; not all encounter with equal degree of shock the countermajoritarian difficulty; some are nearer the passive end than others" (Ibid, p. 207).

261 "The Court's first obligation is to move cautiously, straining for decisions in small compass, more hesitant to deny principles held by some segments of the society than ready to affirm comprehensive ones for all, (...) and always anxious first to invent compromises and accommodations before declaring firm and unambiguous principles". (The Morality of Consent, p. 25.)

${ }^{262}$ The Morality of Consent.
} 
sua defesa da constituição liberal. ${ }^{263}$ Rejeita uma corte absolutista dos princípios, convicta ao modo da tradição contratualista francesa. Prefere uma corte burkeana, gradualista, cética, prudente e realista ao estilo político inglês. A primeira vertente, poderíamos cogitar, apega-se à última palavra. A segunda, ao diálogo.

Seu conservadorismo não denota o desejo de manutenção do status quo, mas sim o de planejamento cauteloso da mudança, ou, nas palavras de Burke, "não produzir nada totalmente novo, e não reter nada totalmente obsoleto". ${ }^{264} \mathrm{~A}$ corte, quando participa do processo de mudança, deve operar como uma "bomba-relógio" da democracia. ${ }^{265}$ A pretensão de mudanças bruscas fracassa, quanto mais as tentadas pela corte. Deve evitar espasmos e prezar pela continuidade. ${ }^{266} \mathrm{O}$ autor menciona dois exemplos opostos: a decisão trágica do caso Dred Scott, que não usou de virtudes passivas para evitar proferir uma decisão de princípio que legitimou um regime repulsivo de escravidão (mesmo que a sociedade ainda não estivesse madura para a total integração, que começou com o caso Brown); e a pena de morte, que ainda não foi extinta nos EUA, mas que poderá ser no momento adequado. ${ }^{267}$

Bickel vê o direito e a política como um processo em fluxo contínuo, não como um conjunto de regras estáticas que vinculam a todos rigidamente no decorrer do tempo. Está preocupado com a acomodação que evite o choque de extremos, não com a teoria ou a ideologia. ${ }^{268}$ Uma corte que assuma a tarefa de promover o progresso sozinha não é uma boa saída. Os efeitos de suas decisões devem ser sentidos no agregado, ao longo do tempo. ${ }^{269}$

\footnotetext{
${ }^{263}$ Esse tema foi discutido por John Moeller, que concluiu: "Politics is the place where Burkean conservatism and Madisonian liberalism can coexist" ("Alexander M. Bickel: Toward a Theory of Politics").

264 "when it does take upon itself to strike a balance of values, it does so with an ear to the promptings of the past and an eye strained to a vision of the future much more than with close regard to the present. Burke's description of an evolution meets the case: to produce nothing wholly new and retain nothing wholly obsolete". (The Morality of Consent, p. 25)

265 "To the extent that they are instruments of decisive change, Justices are time bombs, not warheads that explode on impact". (The Least Dangerous Branch, p. 31)

266 "But it is the function of the Court - in the sphere of its competence - to maintain the continuity in the midst of change. Change should be a process of growth. (...) Change should not come about in violent spasms. Government under law is a continuum, not a series of jerky fresh departures. And so the past is relevant. (...) control the rate of change in society. Moreover, the recorded past is, of course, experience; it is a laboratory in which ideas and principles are tested". (Ibid, p. 108)

267 "But only a shortsighted and rather imprisoned lawyer would maintain that capital punishment can never be declared unconstitutional" (Ibid, p. 241)

${ }^{268}$ Ibid, pp. 10 e 19.

269 "We wish it to endure (...) because, aside from its forays into broad social policy, the Court discharges a much narrower, but still reasoned and principled, law-making function. It makes law
} 
Em síntese, o que procurei expor não foi só o Bickel preocupado com a dificuldade contramajoritária, mas com uma corte que estimule o diálogo. A corte, para ele, não é o animal político que inspira as correntes dos Critical Legal Studies ou da ciência política. Não é um ser puramente ideológico. É político porque precisa exercer prudência, calcular como sua decisão será recebida pela opinião pública e fazer um prognóstico.

O objetivo de seu principal livro é contribuir para o entendimento das virtudes passivas e para uma administração mais deliberada e criteriosa delas. As virtudes passivas são, para ele, prática inevitável de uma corte duradoura. Se a corte quiser governar tudo que tocar, tornar-se-ia um "reino platônico contrário à moralidade do auto-governo". ${ }^{270}$ Saber se, quando, e quanto decidir é um problema não resolvido. Bickel aponta para isso e inspira uma revisita à questão. Soma à pergunta "é constitucional?" a pergunta "é o momento certo de decidir?" ou "há razões para esperar?". Ainda que a proposta das virtudes passivas possa ser insatisfatória, parece abrir uma janela frutífera e necessária para entender um papel da corte que é, no mínimo, mais colorido do que convencionalmente se acredita.

A decisão de esperar é feita por uma ponderação que está fora da análise de estrita constitucionalidade. Envolve a percepção do momento oportuno e maduro para a mudança de rota do projeto constitucional. Difícil sustentar que ela não integre as variáveis decisórias da revisão judicial. O desafio é saber como lidar com essa técnica que, quando utilizada de maneira dissimulada, impede o debate, o controle e a crítica, e permanece no conforto das escolhas subterrâneas.

A participação da corte na política é mais sutil e imaginativa do que o senso comum admite. Não se trata somente de aplicar o direito ou proteger a sociedade contra suas fraquezas e vicissitudes, mas também de criativamente liderar a agenda pública sobre temas amortecidos e dormentes, apontar horizontes e provocar reações. Nada disso é captado por teorias da interpretação, que não nos permitem ler a rica teia estratégica em que a corte está enredada. Bickel traz clareza a isso, e mostra que a interstitially, with effects that may be far-reaching and widely felt, if they are at all, only in the aggregate, over time" (The Supreme Court and the Idea of Progress, p. 176).

${ }^{270}$ The Least Dangerous Branch, p. 199. 
última palavra é "uma questão de grau". ${ }^{271}$ Segundo ele, a "expectativa de vida" de um princípio não costuma ser maior do que uma ou duas gerações. Portanto, decisões da corte sempre serão provisórias. ${ }^{272}$

O mais próximo dessa percepção que teorias da interpretação constitucional conseguiram chegar foi na noção de "living constitution", de "mutação constitucional", de que o texto se adapta ao tempo e está sujeito a desenvolvimentos e mudanças ao longo da história. É importante entender e conceituar esses diferentes papéis, em vez de jogá-los na vala comum, genérica e indistinta (em geral, pejorativa e resignada) de que "a corte é política".

Para Bickel, a corte é, com todas as qualificações que o afastam de Dworkin, um fórum de princípio. Mas, antes, tem que exercer sabedoria prática por meio das virtudes passivas. Não confia na legitimidade automática das grandes ousadias de ativismo judicial, que avocam o leme da história e definem a direção do progresso. $\mathrm{O}$ enraizamento de um princípio na sociedade não é tarefa da corte sozinha. Bickel quer saber como a corte, sem uma atitude imperial e monopolística, pode insuflar na política a dimensão de princípio, da visão de longo prazo. ${ }^{273}$

Pode parecer que a posição defendida por ele culmina numa corte tímida, de fachada, mero coadjuvante. O ponto dele, porém, é mais preciso. Quer saber como, sem decidir, a corte pode fazer o legislador e a sociedade se movimentarem e acomodarem seus impulsos por mudança. Tudo isso, através da arte do compromisso. Clama pela percepção da complexidade do processo político, que pode tornar grandes declarações de princípio inócuas na prática (mesmo que, no mérito, concordássemos com elas). A missão da corte não é encontrar a "resposta certa", mas a resposta que melhor consiga liderar a sociedade (caso não possa exercer as virtudes passivas e incentivar o colóquio). A técnica decisória que ele propõe requer a modulagem consciente das virtudes passivas - exercício que demanda imaginação, pois essas técnicas resistem à codificação.

\footnotetext{
271 "Finality is a matter of degree" (Ibid, p. 117).

272 "And so what one means by the ultimate, final judgment of the Court is quite frequently a judgment ultimate and final for a generation or two". (Ibid, p. 244)

273 "Judicial review brings principle to bear on the operations of government" (Ibid, p. 199).
} 
Bickel não está encapsulado na perspectiva interna da revisão judicial, pensando apenas em como decisões de princípio devem ser tomadas, mas como as decisões judiciais integram o desafio complicado da efetividade das decisões políticas. Ele está discutindo a arte de governar e o lugar da corte na tarefa de gerir uma comunidade, de mantê-la costurada. Tem o mérito de colocar a discussão sobre legitimidade democrática num quadro mais sofisticado dos tipos variados de decisão que a corte toma.

Anthony Kronman, entre outros, defende uma reavalição do papel atual da prudência no pensamento político, e considera subestimada a importância de Bickel. A prudência, virtude fora de moda, não deveria ser descartada como obscurantista e necessariamente conservadora. A pessoa prudente, para ele, resiste à tentação dos imperativos morais, tolera acomodações e a baixa velocidade das mudanças, valoriza o consentimento. Esse tipo de disposição seria também virtuosa para instituições políticas. $^{274}$

Certamente, há muitas perguntas que Bickel não responde: Como provocar o colóquio se as virtudes passivas são válvulas para não dizerem nada sobre o caso? É plausível a expectativa de que, ao não decidir, o tema continue na agenda pública? Qual o impacto dessa variável prudencial dentro do raciocínio jurídico? Em que medida as virtudes passivas são legítimas? Cass Sunstein, no próximo tópico, ajuda a desenvolver algumas dessas questões.

\subsubsection{Cass Sunstein e o minimalismo: a corte quando navega mares desconhecidos}

Cass Sunstein é o autor que conferiu às idéias de Bickel um contorno teórico mais refinado. Batizou sua teoria da revisão judicial de minimalismo: a prática de dizer não mais do que o necessário para justificar o resultado, e deixar o máximo possível não decidido. ${ }^{275}$ Essa teoria, em regra, evita o maximalismo: a atitude de decidir, em todo caso, tudo o que pode ser decidido. Ao contrário de Bickel, que

\footnotetext{
${ }^{274}$ Kronman, numa passagem elucidativa: "A prudent judgment or political program is, above all, one that takes into account the complexity of its human and institutional setting" ("Alexander Bickel's Philosophy of Prudence", p. 1569).

${ }^{275}$ One Case at a Time, p. 3.
} 
investiga "as técnicas da não decisão", Sunstein está interessado em explorar uma faceta mais produtiva das virtudes passivas. ${ }^{276}$ Bickel prioriza seu olhar sobre a corte nos momentos em que ela "decide não decidir". Sunstein prefere olhar para o momento em que a corte decide, mas decide pouco. Diferencia-se, também, daqueles que defendem as "virtudes ativas", uma corte que decide muito, conforme verificaremos no tópico seguinte.

Sunstein ameniza um ponto que parece problemático em Bickel. Para este autor, a corte deve deixar de decidir lançando mão de técnicas processuais discricionárias e difíceis de serem controladas racional e publicamente. Para Sunstein, a corte deve decidir o mínimo possível - exercício que ainda está dentro do poder de invalidar ou legitimar com base em princípio. A fundamentação dessa decisão, porém, é modesta. Ele desdobra ainda mais as nuances e diversidade de escolhas dentro da adjudicação constitucional, e explora a hipótese que parece uma heresia para o estado de direito pensado em termos mecânicos e binários: a proibição do non liquet, da decisão que não soluciona o caso.

Não se ouve tão obviamente, em Sunstein, os ecos do conservadorismo burkeano e sua resistência a mudanças abruptas em nome de acomodações e concessões ao compromisso. Está preocupado com o risco da decisão judicial errada, e também com a decisão certa que, por ser muito ambiciosa, gera efeitos contraproducentes. Inscreve sua teoria no "princípio liberal de legitimidade"277 e se preocupa com a democracia deliberativa, ideal com o qual, segundo ele, a constituição americana teria se comprometido. Nas suas palavras, esse projeto político quis construir uma "república das razões", em que todo ato de autoridade é acompanhado de justificativas. ${ }^{278}$

No lugar das virtudes passivas, Sunstein cria um vocabulário novo: "deixar coisas não decididas" (leaving things undecided), "acordos teóricos incompletos" (incompletely theorized agreements) e "uso construtivo do silêncio" são as expressões

\footnotetext{
276 'My suggestion is that the notion of the 'passive virtues' can be analyzed in a more productive way if we see that notion as part of judicial minimalism and as an effort to increase space for democratic choice and to reduce the costs of decision and the costs of error" (One Case at a Time, p. 40).

277 "I am thus suggesting a form of minimalism that is self-consciously connected with the liberal principle of legitimacy" ("Foreword: Leaving Things Undecided", p. 8).

${ }^{278}$ The Partial Constitution, p. 17.
} 
que sintetizam o minimalismo. Percebe que, ao menos na Suprema Corte americana, juízes freqüentemente decidem pouco e fazem escolhas deliberadas sobre o que deveria permanecer não dito. Não adotam e nem se comprometem com uma teoria unitária da interpretação. "Em vez de adotar teorias, eles decidem casos". ${ }^{279} \mathrm{O}$ minimalismo é uma forma de auto-contenção, mas não se confunde com as outras modalidades existentes. Rejeita a auto-contenção como regra geral ou o apreço irrestrito ao majoritarismo, que são crenças maximalistas. Os minimalistas "preferem deixar questões fundamentais não decididas. Esta é a sua característica mais distinta". 280

Minimalistas evitam raciocínios dedutivos. Preferem examinar as particularidades do caso e pensar por meio de analogias e casos hipotéticos. ${ }^{281}$ São conscientes de suas limitações e atentos às conseqüências imprevisíveis de suas decisões. A principal qualidade da prática minimalista seria a redução do ônus da decisão judicial, pois não força juízes a concordarem com formulações muito gerais. Tornaria, por isso, os erros judiciais menos freqüentes e danosos. $\mathrm{O}$ juiz minimalista não tenta decidir de uma vez por todas. A decisão minimalista não reduz o espectro de possibilidades para discussões e decisões posteriores. Assim, favorece novos debates e enriquece a democracia deliberativa. ${ }^{282}$ Quando a corte está lidando com uma questão de alta complexidade (pela falta de informação, pelas circunstâncias cambiantes ou incerteza moral), na qual a sociedade se encontra dividida, esta seria a melhor estratégia judicial.

O minimalismo tem componentes formais e substantivos. Do ponto de vista formal, a decisão deve ter duas qualidades: deixar questões não decididas e perseguir acordos teóricos incompletos. Em outros termos, o minimalista consistente defende decisões estreitas em vez de largas, rasas em vez de profundas. Explique-se.

Decisões judiciais podem ser pensadas em duas dimensões. A dimensão da largueza diz respeito ao número de casos atingidos pela decisão. Numa decisão estreita, nesse sentido, o juiz esforça-se por decidir somente o caso que tem diante de

\footnotetext{
${ }^{279}$ One Case at a Time, p. 9

${ }^{280}$ Ibid, p. $\mathrm{x}$.

${ }^{281}$ Ibid, p. 9.

${ }^{282}$ Ibid, p. 4.
} 
si, e por minimizar os reflexos jurídicos sobre outros casos. A dimensão da profundidade, por sua vez, diz respeito às variações no nível de abstração. Num "acordo teórico incompleto", juízes buscam concordar com uma solução concreta sem precisar ascender no nível das razões utilizadas. Trata-se de uma técnica de redução do desacordo. Às vezes, a redução do desacordo funciona da maneira inversa. Num processo constituinte, por exemplo, é mais fácil conquistar o acordo em relação a princípios abstratos do que resolver detalhes concretos da constituição. ${ }^{283}$ Essa seria a técnica da "abstração não completamente especificada". Portanto, em certas situações, pessoas lutam no plano abstrato e convergem no concreto. Em outras, convergem nos grandes princípios, mas divergem na sua aplicação.

Acordos e desacordos podem ter muitas virtudes, mas também riscos. ${ }^{284}$ Ambos podem ser sinal de respeito mútuo, mas, eventualmente, sinais autoritários também. Qual a combinação ótima de acordo e desacordo numa sociedade democrática? Quanto precisa do primeiro para viabilizar a convivência? Quanto do segundo para permitir a criatividade, a busca de soluções originais, o controle do poder? Para Sunstein, esse é um problema que só pode ser resolvido pragmaticamente.

Ambas as técnicas para redução de desacordos (elevar e reduzir a abstração) são indispensáveis para a constituição de uma sociedade, e certamente para a manutenção de uma sociedade pluralista. ${ }^{285}$ Para Sunstein, elas são um sinal de respeito mútuo. ${ }^{286}$ Nos casos judiciais, o mais importante é conquistar a primeira meta. ${ }^{287} \mathrm{O}$ minimalismo judicial, portanto, promove um "objetivo crucial do sistema

\footnotetext{
${ }^{283}$ [Many constitution-making processes] "succeeded by virtue of incompletely theorized agreements in the form of incompletely specified abstractions" (Ibid, p. 12).

284 "Incompletely theorized agreements have many virtues; but their virtues are partial. Stability, for example, is brought about by such agreements, and stability is usually desirable; but a constitutional system that is stable and unjust should probably be made less stable. (...) In law, as in politics, disagreement can be a productive and creative force, revealing error, showing gaps, moving discussion and results in good directions. (...) Agreements may be a product of coercion, subtle or not, or of a failure of imagination". ("Constitutional Agreements Without Constitutional Theories")

285 "A key task for a legal system is to enable people who disagree on first principles to converge on outcomes in particular cases. Incompletely theorized agreements help to produce judgments on relative particulars amidst conflict on relative abstractions. (...) But judges must decide many cases quickly; they have limited time and capacities". ("Incompletely Theorized Agreements")

${ }^{286}$ Ibid, p. 14.

287 "Agreements on particulars and on unambitious opinions are the ordinary stuff of constitutional law" (Ibid, p. 13).
} 
político: torna possível que pessoas concordem quando o acordo é necessário, e torna desnecessário que pessoas concordem quando o acordo é impossível”. ${ }^{288}$

Obviamente, a avaliação de decisões judiciais como largas ou estreitas, profundas ou rasas, recorre a medidas gradualistas. Por mais que tente ser estreita, uma decisão judicial racional sempre transcende o caso concreto em algum grau. $\mathrm{O}$ esforço do juiz é por minimizar essa medida, sem desrespeitar o dever de proferir uma decisão fundamentada. Pensando num contínuo, Sunstein exemplifica essas variações: num extremo, está a decisão bruta, descolada da pronúncia de razões. No outro, está a decisão que preenche todo o espaço de teorização sobre o assunto. ${ }^{289} \mathrm{O}$ minimalismo e o maximalismo com os quais Sunstein lida estão na zona intermediária. Vale observar que essas dimensões também não são estáticas, mas se cruzam: é possível encontrar decisões profundas e estreitas, rasas e largas, e assim por diante. ${ }^{290}$

Do ponto de vista substantivo, o minimalismo precisa proteger alguns elementos constitucionais essenciais, sem os quais a prática minimalista não encontra razão de ser. Esse coração substantivo não é estático, e pode variar com a história. Para a sociedade americana, no presente, este núcleo consensual corresponde ao conjunto de direitos democráticos básicos previstos na constituição. ${ }^{291}$ Nesse ponto do argumento, pode-se desconfiar que Sunstein não está propriamente defendendo o minimalismo, mas selecionando temas em que a decisão judicial deve ser larga e profunda. Faz uma concessão ao maximalismo, donde se percebe que sua defesa do minimalismo é relativa, não absoluta. O minimalismo é mais adequado em certas hipóteses. O maximalismo, em outras. Quais seriam elas?

Sunstein oferece alguns parâmetros abstratos, a serem conferidos caso a caso. Recomenda a atuação maximalista quando o juiz tenha (i) "considerável confiança no mérito da solução", quando a (ii) "solução possa reduzir o custo da incerteza" para litigantes futuros, quando (iii) o planejamento for importante, e quando (iv) lidar com as pré-condições da democracia ou criar incentivos que tornem mais provável a prestação de contas das instituições eleitas. O minimalismo, por sua vez, seria mais

\footnotetext{
${ }^{288}$ One Case at a Time, p. 14.

${ }^{289}$ One Case at a Time, p. 10.

${ }^{290}$ Ibid, p. 16.

${ }^{291}$ Ibid, p. 63.
} 
adequado quando o caso envolver (i) grande incerteza factual ou moral, quando uma (ii) solução tiver o risco de confundir casos futuros, quando a (iii) necessidade de planejamento não for premente e quando as (iv) pré-condições da democracia não estiverem em jogo. Portanto, Sunstein deixa claro que "a defesa do minimalismo não é separável de uma avaliação das controvérsias substantivas subjacentes”. ${ }^{292}$

Aparentemente, são orientações triviais. Mas, em coerência com a teoria de Sunstein, formular orientações mais precisas pode trair o seu próprio espírito particularista, caso a caso. Por essa razão, seu livro prefere argumentar por meio de exemplos concretos de cada circunstância. ${ }^{293} \mathrm{O}$ argumento do autor é flexível o suficiente, nesse sentido, para acomodar o minimalismo e o maximalismo. As duas estratégias são legítimas e adequadas, a depender da avaliação do contexto. Não se pode apoiar ou rejeitar um ou outro em abstrato e sem maiores qualificações. ${ }^{294}$ Essa ressalva é feita várias vezes em seu livro.

Há, contudo, uma presunção em favor do minimalismo. As exceções dizem respeito ao mínimo substantivo que o minimalismo pressupõe, de modo que ele faça sentido como técnica promotora da democracia deliberativa. Decisões judiciais, em geral, devem ser "catalíticas em vez de preclusivas" de deliberações posteriores, e, para tanto, algumas pré-condições precisam estar preservadas. ${ }^{295}$ Afora essas condições, a corte está navegando "mar desconhecido". ${ }^{296}$ Pode preferir silenciar, seja porque não tem segurança de que está certa, seja porque teme a reação pública. ${ }^{297} \mathrm{O}$ maximalismo também ambiciona promover a democracia, mas o minimalismo tem

\footnotetext{
${ }^{292}$ One Case at a Time, p. 57.

${ }^{293}$ É interessante, p. ex., a comparação, sob o ponto de vista dos efeitos, entre os casos Dred Scott, Brown e Roe. Correspondem, respectivamente, segundo Sunstein, ao caso mais vilificado, ao mais celebrado e ao mais contestado da história constitucional americana, e são episódios que oferecem boas lições sob o ponto de vista do minimalismo. (Ibid, p. 36).

${ }^{294}$ Como sugere a pergunta rígida de Michael Heise: "Specifically, will active, robust court participation enhance the deliberative processes and thereby advance democratic principles? Or, in contrast, will active court participation erode or supplant the constitutional duties allocated to the executive or legislative branches?" A provável resposta de Sunstein seria: "Depende". (Cf. "Preliminary Thoughts on the Virtues of Passive Dialogue", p. 84).

295 "For this reason courts should usually attempt to issue rulings that leave things undecided and that, if possible, are catalytic rather than preclusive. They should indulge presumption if favor of minimalism". (One Case at a Time, p. 5-6)

296 "Like a sailor on an unfamiliar sea (...) a court may take small, reversible steps, allowing itself to accommodate unexpected results". (One Case at a Time, p. 259)

${ }^{297}$ Ibid, p. 23
} 
maior desconfiança da capacidade de o juiz fazê-lo. ${ }^{298}$ A escolha entre um e outro, nesse sentido, necessita de uma avaliação comparativa de capacidade institucional. ${ }^{299}$

Entre um e outro há oscilações de grau, não de tipo. Ambos estão mirando o diálogo e a democracia. Um, por meio de uma participação judicial mais substantiva. O outro, por meio de provocações e pelo "uso construtivo do silêncio". Este prefere devolver o problema, levantar perguntas, exigir clareza das definições ambíguas do legislador etc. ${ }^{300}$

Sunstein reflete sobre o impacto de cada tipo de decisão na deliberação democrática. Uma validação maximalista dá um claro sinal para os outros poderes, mas não se deve celebrá-la do ponto de vista da deliberação. Uma invalidação maximalista é, em regra, a mais prejudicial. De outro lado, uma validação minimalista deixa questões em aberto, mas não estimula tanta continuidade deliberativa. Finalmente, a hipótese sobre a qual Sunstein mais se debruça: a invalidação minimalista tem a maior potência para despertar debates ricos. ${ }^{301}$

O minimalismo pode causar certa repulsa à sensibilidade jurídica de alguns. A reação mais óbvia contra um juiz que se esforça por limitar a largueza e profundidade das decisões judiciais é que isso vai de encontro aos valores básicos do estado de direito: certeza, segurança, máxima capacidade de planejamento etc. ${ }^{302} \mathrm{O}$ ápice dessas qualidades é conquistado por decisões largas e profundas. Sunstein escapa dessa objeção ao admitir que, nas áreas em que tal previsibilidade for fundamental (como

\footnotetext{
298 "Courts know that they may be wrong, and they know too that even if they are right, a broad, early ruling may have unfortunate systemic effects. It may prevent the kind of evolution, adaptation, and argumentative give-and-take that tend to accompany lasting social reform". (One Case at a Time, p. 26)

299 "These points show that no defense of minimalism should be unqualified. Sometimes minimalism is a blunder; sometimes it creates unfairness. Whether minimalism makes sense cannot be decided in the abstract; everything depends on context, prominently including assessments of comparative institutional competence". (Ibid, p. 262)

${ }^{300} \mathrm{Ibid}$, p. 27 (lista de técnicas minimalistas promotoras da democracia pois forçam o legislador a deliberar).

301 "In such cases, courts attempt to promote what I have suggested are the two goals of a deliberative democracy: political accountability and reason-giving" (Ibid, p. 28).

302 "Here there is an argument for width as a judicial virtue. It is a virtue because it promotes rule of law values, by limiting judicial discretion and improving predictability. But it is also a democratic virtue, because it creates a reliable backdrop for use by citizens and representatives". (One Case at a Time, p. 22)
} 
contratos e propriedade, ele exemplifica), a corte pode e deve ser maximalista. ${ }^{303}$ Mas seu ponto é mostrar que, para uma democracia, é também fundamental que a corte deixe coisas não decididas. Nem sempre há tanta razão para celebrar as qualidades de uma decisão judicial moralmente grandiosa. Com freqüência, do ponto de vista moral, “o insulamento em relação às pressões majoritárias é o problema, não a solução". Não se trata de abandonar o heroísmo moral da corte. "Ao seu próprio modo discreto, o minimalismo pode ser heróico também", ${ }^{304}$

\subsection{Virtudes ativas}

\subsubsection{Uma segunda chance ao legislador: a corte como conselheira}

Bickel e Sunstein são hoje as duas referências canônicas da defesa de uma corte promotora do diálogo por meio de uma ação prudente e minimalista. Alguns autores mais recentes, contudo, exploram a possibilidade de a corte buscar o mesmo objetivo adotando estratégia oposta: em vez de silenciar, a corte aconselha e manda recados por meio de suas decisões.

Katyal é o autor que sistematizou concretamente, num longo artigo, essa via de ação. Aconselhamento consiste no ato de recomendar, mas não de impor, um rumo decisório específico a outro poder. ${ }^{305}$ Segundo ele, sua tentativa é dar continuidade "a uma história contada, primeiramente, por Bickel”. Este teria tido o mérito de mostrar que a corte tem uma saída intermediária entre validar e invalidar, e transcendeu a opção dicotômica. Sunstein, a partir daí, desenvolveu essa idéia e construiu formas de "silêncio jurisprudencial".

Para Katyal, todavia, o silêncio e a inação não são as únicas alternativas. A corte, nas suas palavras, pode ser mais "proativa". Há um quarto poder escondido nos interstícios dos outros três. Especificamente, quando juízes atuam como

\footnotetext{
303 "If a court has reason for confidence about the theoretical foundations of some area of law, it has earned the right to depth; I have suggested that this is now true for the area of sex equality. When there is a great need for predictability, and good reason for confidence that an adequate rule can be advised, width is entirely appropriate and perhaps indispensable; consider property and contract law". (Ibid, p. 263)

304 “Testing minimalism: a reply", p. 128.

305 "Advicegiving occurs when judges recommend, but do not mandate, a particular course of action based on a rule or principle in a judicial case or controversy". (Neal Kumar Katyal, "Justices as Advicegivers", p. 1710).
} 
conselheiros. ${ }^{306}$ A corte pode aconselhar quando valida, quando invalida e quando usa das virtudes passivas. $\mathrm{O}$ aconselhamento seria uma "adaptação natural" num contexto em que juízes temem ter sua legitimidade questionada em razão de decisões muito amplas e interventivas.

Para evitar a interferência, portanto, juízes tomam decisões estreitas, mas adicionam a elas, por meio de obiter dicta, conselhos de maior amplitude. Como o conselho é veiculado pelos obiter dicta da decisão, e não pela sua ratio, tem maior flexibilidade e não é vinculante. Não deixa de propiciar, porém, alguma previsibilidade e direção, pois é dada ex ante. Essa seria sua principal vantagem em relação ao minimalismo. ${ }^{307}$ Seria uma técnica mais efetiva para promover a democracia e a adaptabilidade da decisão judicial. ${ }^{308}$

Juízes, de forma implícita ou explícita, freqüentemente fornecem conselhos em suas decisões. Trata-se de uma técnica difícil de se eliminar da argumentação judicial (exceto pela absoluta disciplina minimalista). Em grande parte das decisões, de forma mais ou menos direta, é possível identificar quais alternativas legislativas a corte aceitaria. Caso o conselho não seja permitido, acabará, provavelmente, sendo sub-reptício no texto da decisão, longe do controle público. Uma tradição aberta de aconselhamento, segundo Katyal, minimizaria a chance de trocas de bastidores, reforçaria a legitimidade da corte e encorajaria a honestidade judicial (judicial candor). ${ }^{309}$

Katyal organiza uma tipologia de conselhos e descreve detalhadamente o objetivo e qualidade de cada um. ${ }^{310}$ Seu projeto estaria na esteira da recuperação de uma "tradição de cooperação e sinergia entre poderes", que rompe com o modelo

\footnotetext{
${ }^{306}$ Ibid, p. 1712-1714.

307 "Advicegiving can attain minimalism's advantage of preserving legislative flexibility while simultaneously tempering minimalism's dangerous tendency to reduce predictability and guidance". (Ibid, p. 1716).

308 "The combination of "narrow-holding + advicegiving dicta" enjoys a natural advantage over broad holdings in terms of democratic self-rule, flexibility, popular accountability, and adaptability". (Ibid, p. 1711).

${ }^{309}$ Ibid, p. 1821.

${ }^{310}$ Os oito principais tipos seriam: 1) Clarificação; 2) Auto-alienação; 3) Personificação; 4) Exemplificação; 5) Demarcação; 6) Prescrição; 7) Educação; 8) Moralização (Ibid, p. 1717-1718). Cf. também o diagrama da p. 1721, mostrando graficamente o espaço intersticial que as técnicas de aconselhamento ocupam frente às três faculdades da corte apontadas por Bickel. Por fim, na p. 1722, há uma tabela que sistematiza e dá exemplos da prática dessas oito técnicas.
} 
adversarial. ${ }^{311}$ Por meio dessas técnicas de aconselhamento, a corte cria condições para que os poderes conversem produtivamente, e evita uma postura que oscila entre a hostilidade ou a pura deferência. ${ }^{312}$ Com propósito semelhante, mas de forma menos sofisticada, Erik Luna propõe que a corte se utilize de técnicas menos agressivas que encorajem a resposta legislativa pós-invalidação judicial. De forma genérica, atribui à corte o papel de cartógrafo: de mapear as alternativas compatíveis com a constituição que o legislador tem (constitutional roadmaps). ${ }^{313}{ }^{314}$ Essa variedade de técnicas decisórias que permitem ao tribunal intervenções mais "suaves" no processo legislativo não são exclusividade da jurisprudência ou da teoria constitucional americanas. ${ }^{315} \mathrm{O}$ princípio da proporcionalidade é um bom exemplo de prática que transcende uma única jurisdição nacional, como se vê no tópico seguinte.

\subsubsection{A técnica da proporcionalidade}

Para encerrar o quadro das virtudes ativas, vale a menção à técnica da proporcionalidade. Não é comum tratá-la no bojo das teorizações sobre diálogo. Parece-se mais com um instrumento de clara supremacia judicial. Ainda que, de fato, confira grande margem de atuação à corte, prefiro referir-me a ela como uma forma forte de exercício de virtudes ativas e, portanto, ainda dentro do diálogo. A sua flexibilidade e abertura para calibração em função do desempenho do legislador

\footnotetext{
${ }^{311}$ Ibid, p. 1822.

312 "Instead of alternating between hostility and deference, courts should self-consciously set out to work in partnership with other branches and other governments". (Ibid, p. 1824).

${ }^{313}$ Erik Luna, "Constitutional Roadmaps", p. 1127-1128.

${ }^{314}$ Guido Calabresi, de forma menos ambiciosa que os outros dois, sugere estratégias pelas quais a corte remete o caso de volta para uma reconsideração (second-look) do legislador. Assim, a corte cria "mini momentos constitucionais" para forçar um exame legislativo concentrado na linguagem constitucional. ("Foreword: Antidiscrimination and Constitutional Accountability [What the BorkBrennan Debate Ignores]", p. 107)

${ }^{315}$ Bons exemplos de práticas dialógicas parecidas em outros países podem ser encontrados no estudo comparativo organizado por Jeffrey Goldsworthy, Interpreting Constitutions, 2006. No artigo de Donald Kommers (“Germany: Balancing Rights and Duties”), que integra essa coletânea, ele classifica três modos típicos de o Tribunal Constitucional Alemão proferir conselhos, apesar de não se lhes reconhecer oficialmente como opinião consultiva: 1) quando o tribunal invalida a lei e indica formas de correção; 2) quando o tribunal não invalida mas confere um prazo ao legislador para que ele a corrija; 3) quando o tribunal declara a incompatibilidade da lei mas não a invalida por ser politicamente inconveniente (p. 211). Kommers observa a importância dessa atitude na legitimação da corte alemã: "This particular approach to constitutional adjudication has avoided the 'absolutist' or categorical reasoning often typical of American constitutional decisions. And the fact that constitutional interpretation is often the by-product of constructive dialogue between the FCC and parliament is still another reason for the relative stability and acceptability of judicial review in Germany's civilian legal system" (p. 214).
} 
deixam claro que, em alguma medida, é disso que se trata, e não de um julgamento estanque de princípio.

A proporcionalidade corresponde a uma moldura analítica para racionalizar a adjudicação sobre a validade de restrições a direitos fundamentais. ${ }^{316}$ Consiste em três passos, ou melhor, submete a legislação a três testes. Em primeiro lugar, ao teste da legitimidade e adequação: verifica se os fins buscados pelo legislador são legítimos e se os meios utilizados têm conexão racional com a persecução daqueles fins. Em seguida, ao teste da necessidade: examina se esses meios são realmente necessários, ou se haveria outro menos gravoso, com capacidade de atingir o mesmo fim. Por último, submete a lei ao teste da "proporcionalidade em sentido estrito", o que mais se aproxima de uma avaliação de custo-benefício: confere se, no caso, a prevalência de um direito sobre outro é proporcional. O legislador tem o dever de otimizar a promoção de um valor e de minimizar a eventual restrição a direito. Basicamente, este último consiste num sopesamento de valores. Se a lei falha, segundo a opinião judicial, em qualquer desses testes, ela é inconstitucional.

Alec Stone-Sweet é um recente entusiasta dessa técnica. ${ }^{317}$ Constata que o exame de proporcionalidade se expandiu para os julgamentos de todas as cortes constitucionais das democracias minimamente estáveis no mundo. É o "parâmetro de melhor prática" (best-practice standard) na jurisprudência constitucional, a técnica dominante sobre adjudicação de direitos. Uma característica já dada como inerente ao constitucionalismo, um “critério de perfeição" do estado de direito. ${ }^{318}$

Essa moldura analítica tem a qualidade de racionalizar, mas nem por isso determina respostas corretas ou "camufla a criação judicial do direito". ${ }^{319}$ É uma estrutura de balanceamento que não clama neutralidade e, assumidamente, faz escolhas de natureza moral e política. No entanto, consegue ao menos uniformizar o argumento e conferir-lhe uma ordem. Por que ela seria um instrumento de diálogo?

\footnotetext{
${ }^{316}$ Com raízes na teoria do direito alemã do séc. XIX, sua formulação atual, aplicada a direitos fundamentais, se deve ao influente livro Teoria dos Direitos Fundamentais, de Robert Alexy.

${ }^{317}$ Alec Stone-Sweet e Jud Mathews, "Proportionality Balancing and Global Constitutionalism". Nesse texto há um útil mapeamento da literatura sobre o princípio da proporcionalidade em diversos países.

${ }^{318}$ Ibid, pp. 4 e 37.

319 "Indeed, waving it will expose rights adjudication for what it is: constitutionally-based lawmaking" (Ibid, p. 4).
} 
Segundo Stone-Sweet, nos contextos em que essa técnica impregnou de forma bem sucedida o discurso jurídico, o judiciário induz os outros poderes a pensar nos seus próprios papéis em termos de proporcionalidade. Cria, portanto, uma linguagem comum pela qual os poderes podem se comunicar e, inclusive, esforçar-se para persuadir a corte da validade de seus atos. Os poderes tornam-se monoglotas e capazes de entender as suas respectivas escolhas.

O autor ainda nota que a aplicação do teste de proporcionalidade pode variar ao longo do tempo, tanto em decorrência de causas exógenas (mudança das circunstâncias históricas), quanto endógenas. Estas últimas são importantes para os meus fins aqui. A depender de como o legislador consiga demonstrar que está levando a proporcionalidade a sério, a corte pode conferir-lhe maior deferência em suas escolhas. $^{320}$ Ao longo do tempo, a corte vai gerenciando essa relação, por vezes contraindo, por vezes expandindo a força da proporcionalidade. Nessa flexibilidade residiria sua virtude.

Essa técnica, assim como as outras expostas acima, tem seus críticos e defensores, céticos e crentes. São muitas as objeções que lhe são dirigidas. Uma leitura minuciosa de decisões e autores foge dos propósitos aqui. Quero apenas propor que, mesmo que por meio de uma condução bastante estrita pela corte, a proporcionalidade é também uma forma de diálogo. Dá ao legislador uma linguagem por meio da qual pode responder, e eventualmente desafiar, a corte.

\subsection{Síntese: virtudes passivas e ativas na promoção do diálogo}

A primeira parte do capítulo procurou entender o diálogo no interior da decisão judicial. Referi-me ao diálogo percebido e administrado pela corte. Há formas mais e menos engajadas de se fazê-lo, e por isso propus a divisão entre virtudes passivas e ativas, inspiradas na expressão de Bickel, para destacar as variações de grau que podem ocorrer nesse engajamento. Quando do exercício da primeira, a corte

\footnotetext{
320 "Change may also occur endogenously. A court, in processing a stream of cases in the same policy domain, may choose to accord more deference to legislative choices, over time, to the extent that lawmakers demonstrate that they are taking seriously proportionality requirements when they legislate”. (Ibid, p. 61).
} 
se restringe ao papel de propulsora, catalisadora e supervisora. Quando da segunda, está menos inibida e impõe-se como regente e diretora. Os autores nos forneceram uma gama variada de imagens para ilustrar o que diziam. Animal político, profeta, líder de opinião, radar, professor, navegador, cartógrafo etc. são algumas das utilizadas para atenuar a pretensão da corte guardiã e heróica, que se vislumbra numa posição como a descrita no capítulo 2 .

A separação entre virtudes passivas e ativas pode ecoar outra dicotomia parecida do direito constitucional, entre auto-contenção e ativismo. A primeira, porém, está no contexto do diálogo. A segunda, no contexto da supremacia judicial. Também não se deve confundi-las com a distinção entre minimalismo e maximalismo, feita por Sunstein. Este autor combina aqueles dois planos: a corte, quando minimalista, desperta o diálogo; quando maximalista, impõe a supremacia judicial. O maximalismo, parece-me, serve justamente para conter o diálogo no que diz respeito às suas pré-condições substantivas. A meu ver, são essas as diferenças entre o ativismo recomendado por Dworkin e o proposto por defensores do aconselhamento ou da aplicação da proporcionalidade. Do mesmo modo, entre a atitude judicial amena sugerida por Bickel e Sunstein, e a propugnada por outras estratégias conhecidas de auto-contenção.

Os autores que apresentei até aqui supõem a possibilidade e defendem o valor dessa interação dialógica, mas acham que a corte tem o poder de escolher entre despertá-la ou não, e também de determinar a forma em que ela vai ocorrer. O diálogo depende da boa vontade da corte, e está ao seu alcance trancá-lo. A divisão dos subtópicos seguiu quatro passos em ordem crescente no exercício da autoridade judicial: a evasão pura e simples, a interferência mínima, o envio de recados e a imposição de uma linguagem para o diálogo.

Supõem também outras coisas: Bickel e Sunstein, que a deliberação entre os poderes e a sociedade será melhor quanto menos a corte se intrometer; Katyal, por outro lado, que o diálogo não será melhor se a corte ficar em silêncio, mas se fizer recomendações, cogitações, argumentação hipotética e analógica, todas de natureza não-vinculante. Este admite, portanto, o desafio legislativo, mas lança-lhe um ônus argumentativo. 
Sunstein resiste à atividade de aconselhamento, ainda que não vinculante, provavelmente porque traria o risco de congelar o debate, e de amortecer as possibilidades de continuidade deliberativa. Talvez superestime a autoridade da corte, ou subestime a do legislador de resistir ao conselho. Katyal não compartilha do medo de Sunstein: em alguma medida, nada impede que decisões posteriores desafiem a corte. O importante seria que o parlamento não adote postura deferente. Se este for engajado, uma corte maximalista não atrapalha, mas talvez torne o debate ainda mais efetivo.

Há nuances institucionais e contextos políticos que, no entanto, tornam o problema mais complicado. Às vezes, é improvável que o parlamento assuma a responsabilidade política por certas decisões. Delegar e livrar-se desse ônus lhe pode ser mais cômodo e conveniente. O minimalismo pode fazer sentido em alguns casos. O maximalismo, ou outras formas de virtudes ativas, em outros. No tópico seguinte, descrevo uma literatura que olha como o desenho das instituições impacta a interação e nos permite avaliar a real capacidade de a corte intervir nesse processo, em cada situação.

\section{Diálogo como produto necessário da separação de poderes}

Há dois ramos principais na literatura que vê o diálogo como fenômeno estrutural da separação de poderes: a canadense e a norte-americana. A divisão é imperfeita, pois não são ramos independentes. Influenciam-se mutuamente nos últimos 20 anos. Começo pela mais antiga e variada. A norte-americana é mais sofisticada metodologicamente e aborda o fenômeno de modo mais plural. Por essa mesma razão, na falta de uma noção estável de "diálogo", qualquer descrição é necessariamente mais pessoal. Exponho, em seguida, a vertente canadense do debate. Mais recente, seus termos têm maior homogeneidade, os marcos mais definidos e diretamente conectados com a mudança de regime constitucional em 1982.

\subsection{O debate americano}


Sistematizar o debate americano é certamente uma tarefa mais trabalhosa e necessariamente seletiva do que o canadense. "Diálogo" é um termo utilizado com freqüência por tradições disciplinares diversas. Optei por dividi-lo em duas partes: na primeira, abordo o grupo conhecido como "construção coordenada", que enfeixa um grande número de autores; na segunda, abordo especificamente Barry Friedman, que dá uma contribuição significativa a esse enfoque sobre a revisão judicial. Interpretação coordenada e a teoria do diálogo de Friedman são partes de um contínuo que tem, num dos extremos, o inimigo comum da supremacia judicial.

\section{Construção coordenada e constituição fora das cortes}

Contra a tradição da supremacia judicial inventada por Marshall, segundo o qual a constituição é uma norma de ordem superior que só faz sentido se estiver acima da política e for protegida por um guardião, nasce uma corrente que recusa essa premissa a partir de variados argumentos e ênfases. Construção coordenada, departamentalismo e constituição fora das cortes são os termos pelos quais esses autores costumam ser classificados. Propõem que a constituição é um instrumento que deve ser interpretado por todos os poderes. A interpretação extra-judicial, nesse sentido, é um fenômeno legítimo e desejável. Para defensores da supremacia, a corte é soberana na interpretação. Para a corrente aqui descrita, a corte é um intérprete a mais dentro de um jogo mais complexo. Há vida constitucional fora das cortes e as teorias centradas na última palavra judicial ofuscam essa constatação.

Em tese, grande parte da literatura de ciência política sobre as relações bilaterais entre os três poderes (judiciário v. parlamento, e assim por diante), ou sobre o jogo estratégico entre eles, é geralmente colocada debaixo dessa rubrica comum. Neste tópico, apresento sucintamente três autores que, combinados, oferecem um panorama mínimo dessa corrente para os fins desse capítulo: Louis Fisher, um dos primeiros a abordar o assunto na teoria constitucional; Keith Whittington, representante já consolidado dessa abordagem; e Mitchell Pickerill, que em livro 
recente oferece pesquisa empírica inovadora sobre a relação entre revisão judicial e deliberação parlamentar. ${ }^{321}$

O principal mérito de Louis Fisher é demonstrar, com exemplos da história americana, que o processo constitucional é mais nuançado do que a simples emissão, pela corte, da última palavra. A última palavra, segundo essa história confirmaria, não pertence a nenhuma instituição. Ao contrário, as instituições, e a corte em especial, continuam a ser testadas e desafiadas enquanto tomarem decisões que não gozem de um mínimo consenso deliberativo. Em temas controversos, a democracia não tem como escapar de uma sucessão ininterrupta de testes. A decisão judicial, eventualmente, é final dentro de um estágio, mas novos estágios políticos se abrem continuamente. ${ }^{322}$ Merece respeito, não adoração. ${ }^{323} \mathrm{~A}$ interpretação constitucional, nesse sentido, é um processo circular que só termina ou se estabiliza quando alcance um mínimo acordo, ainda que com prazo de validade.

Whittington promove uma defesa normativa da interpretação constitucional extrajudicial, além de verificar que, empiricamente, ela está presente todo o tempo. Olhar para essa dimensão ampliada é a proposta de sua teoria. A resposta que ele dá aos críticos da interpretação extrajudicial permite uma aproximação mais rápida do seu argumento. ${ }^{324}$ Supremacia judicial não se confunde com exclusividade judicial. Seus defensores admitem que outros poderes podem participar da construção de sentido constitucional, mas acreditam que um dos poderes precisa ter o papel primordial. Se outros poderes reconhecem essa autoridade da corte, a prática de interpretação extrajudicial não representa uma ameaça à supremacia judicial. ${ }^{325}$ No entanto, Whittington questiona esse tipo de hierarquia dos intérpretes e apresenta como alternativa o "departamentalismo" ou "construção coordenada", segundo a qual nenhum intérprete é supremo, mas dotados de igual autoridade. Sob esse enfoque, diferentes acomodações vão surgindo no decorrer do processo político.

\footnotetext{
${ }^{321}$ A leitura desses três autores oferece um mapa extenso de toda a bibliografia sobre o assunto. Nessa lista, são nomes obrigatórios o de Walter Murphy e a escola de direito público que se formou ao redor dele em Princeton, Robert Burt, Susan Burgess, Terri Perretti, entre outros.

322 Cf. Constitutional Dialogues, pp. 8, 273, 275.

323 "Court decisions are entitled to respect, not adoration. When the Court issues its judgment, we should not suspend ours". (Constitutional Dialogues, p. 279)

${ }^{324} \mathrm{O}$ texto recente que mais repercussão teve na defesa da supremacia judicial foi o de Larry Alexander e Frederick Schauer, “On Extrajudicial Constitutional Interpretation”. Whittington responde a eles no texto "Extrajudicial Constitutional Interpretation: Three Objections and Responses".

${ }^{325}$ Ibid, p. 782.
} 
Os críticos apontam três vícios dessa concepção de separação de poderes: seria anárquica (por multiplicar os intérpretes sem hierarquizá-los ou dispor de uma autoridade final e estável), ${ }^{326}$ irracional (por não levar a sério considerações de princípio como a corte o faria), e tirânica (por representar um perigo às minorias, que estariam sob proteção da corte). A supremacia judicial corrigiria esses três vícios por meio de três virtudes: a de resolução definitiva do problema, de sua qualidade deliberativa única, e de sua força contramajoritária.

Whittington recusa essas respostas. Quanto ao suposto caráter anárquico e à virtude judicial de resolução definitiva, afirma que os críticos estão, ao mesmo tempo, superestimando a habilidade de o judiciário resolver o problema, e subestimando a capacidade de os outros poderes produzirem decisões coerentes e estáveis. Além disso, estabilidade e clareza, que contribuem para a função de coordenação social, seriam apenas um dos valores subjacentes ao direito, e devem ser balanceados com outros. A extrema rigidez, especialmente no contexto constitucional, pode prejudicar experimentações importantes para a dinâmica social. ${ }^{327}$ Como o constitucionalismo consiste no balanceamento de diversos valores, e não na maximização de um só, esse argumento pela supremacia judicial perde sua força. Faria duas suposições enganosas: que a estabilidade é o único valor constitucional, e que a corte a promoveria. ${ }^{328}$

Quanto à acusação de irracionalidade na interpretação dos outros poderes e à qualidade de "fórum do princípio" das cortes, Whittington aponta novamente as suposições equivocadas por trás dessa idéia. Salienta que a capacidade interpretativa singular da corte é uma mistificação que não se verifica na realidade. Os juízes de uma corte colegiada, no seu dia a dia decisório, negociam e barganham seus votos. A decisão final da corte, com freqüência, consiste numa cacofonia de opiniões distintas longe da imaginada qualidade da argumentação com base em princípio. Ao mesmo tempo, sustentar que a interpretação extra-judicial será sempre refém da pressão política, da conveniência, e distante do debate moral, não corresponderia,

\footnotetext{
${ }^{326}$ O que Whittington chama de "protestantismo na interpretação da constituição". (Ibid, p. 788)

${ }^{327}$ Ibid, p. 791.

328 "There must be some finality to the resolution of constitutional and legal disputes for society to function productively, but constitutional equilibria can be achieved in myriad ways and the stability of the constitutional environment is best regarded as a continuous rather than a dichotomous variable". (Ibid, p. 808).
} 
rigorosamente, à realidade. ${ }^{329}$ Exigir que a corte não preste deferência, em nenhuma circunstância, para interpretações extrajudiciais, em razão de sua suposta instabilidade e irracionalidade, seria um movimento teórico equivocado.

Por fim, opõe-se também à tradicional defesa da missão anti-tirânica da corte, em nome da proteção de minorias. Para Whittington, essa moldura mental confunde a dinâmica política real entre os poderes, que não corresponde a uma oposição entre maiorias e minorias. Juízes são constrangidos e, ao mesmo tempo, motivados pelo clima político. O papel da corte é mais modesto do que opor-se a forças majoritárias. Ela publiciza potenciais violações constitucionais que passam despercebidas ou despertam a indiferença dos outros poderes. ${ }^{330 \_} 331$ A política americana seria melhor descrita em termos pluralistas do que majoritários, e não é uma boa saída teórica isolar a constituição da política. ${ }^{332}$ Numa frase indicativa dessa idéia: "O significado da constituição não pode ser presumido. Ele precisa ser conquistado, e conquistado dentro da política". 333

Existiria um "continuum de autoridade interpretativa" que oscila no interior dos poderes no decorrer do tempo, e não segue uma bula prefixada. A interpretação extrajudicial é um fenômeno real e inevitável, ainda que nem sempre percebido. A questão normativa central não é, por isso, discutir se ela deve ocorrer, mas saber quanta deferência os poderes devem conceder-se reciprocamente em cada momento. ${ }^{334} \mathrm{O}$ valor da interpretação extrajudicial é o estímulo que ela traz à

\footnotetext{
329 'The ready assertion that 'power' not 'reason' characterizes nonjudicial bodies and precludes extrajudicial constitutional interpretation is theoretically underdeveloped. (...) It is false to assume that individual politicians do not therefore have to explain and justify their actions. (...) Admittedly, the modes of legitimate argument available to legislators are more extensive than those available to judges". (Ibid, p. 822)

${ }_{330}$ "The Court can make a significant difference in political life at the margin. But the Court's constitutional interpretations are most important when it acts in concert with or in the absence of political majorities rather than as strongly countermajoritarian force, when judicial interpretation converges rather than diverges from extrajudicial constitutional interpretation, though the judiciary may be able to identify constitutional applications and violations that would, otherwise, escape political notice" (Ibid, p. 834-835).

${ }^{331}$ Em outro texto, Whittington também afirma a mesma idéia de forma mais direta: "What constitutional courts do best is to publicize constitutional transgressions" ("Constitutional Constraints in Politics", p. 8).

332 "Such a framework obscures more than it enlightens. It relies on a model of an externalized Constitution that imposes itself on political actors through some independent third party". ("Extrajudicial...", p. 839).

333 "The meaning of a constitution cannot be taken for granted. It must be won, and it must be won within politics" ("Constitutional Constraints in Politics", p. 18).

334 “Extrajudicial...", p. 848.
} 
"sensibilidade constitucional" entre os outros poderes: "Somente se pode esperar que os atores políticos não considerem a constituição em termos puramente instrumentais se a interpretação constitucional extrajudicial for levada a sério e valorizada". 335

Pickerill, por sua vez, realiza uma pesquisa empírica reveladora na literatura sobre a construção coordenada. Seu objetivo é verificar em que circunstâncias o legislador tende a deliberar seriamente sobre os valores constitucionais. Pelos períodos estudados, o nexo causal identificado vai de encontro ao que sempre postulou a tradição: a presença, e não a ausência, de uma ameaça real de revisão judicial faz o legislador considerar com mais cuidado a dimensão constitucional dos assuntos que trata. Na história política americana, pelo menos no tema do federalismo analisado por ele, o longo período de deferência judicial entre 1930 e 1990 significou, no parlamento, a total ausência de debates constitucionais, o sumiço da constituição. ${ }^{336}$ Nos períodos que antecedem e sucedem a esses dois marcos, quando a corte retomou algum engajamento sobre o assunto, o parlamento passou a construir argumentos constitucionais com mais cuidado. Trata-se de uma conclusão menos otimista que a de Whittington sobre a capacidade de o parlamento empreender uma interpretação constitucional séria. ${ }^{337}$ Não significa, porém, que Pickerill sucumba à defesa da pura supremacia judicial.

Sua tese é mais elaborada. Verifica que, apesar de o legislador poder responder à decisão judicial e ter variadas estratégias para tanto, é muito raro que ele tenha interesse em fazê-lo. Dentro da gama de incentivos e considerações que pesam na decisão legislativa, o argumento de princípio ocupa posição pouco prestigiada. Sempre que o legislador puder, em alguma medida aceitável, atender o objetivo da política pública e, ao mesmo tempo, obedecer os limites impostos pela corte, ele irá fazê-lo. É isso que realmente acontece na rotina da política normal. Em vez de pensar nos grandes momentos constitucionais de impasse, em que o legislador eventualmente se vê forçado a engajar-se nos debates morais candentes, essa preocupação está fora de sua agenda no dia-a-dia político.

\footnotetext{
${ }^{335}$ Ibid, p. 850-851.

${ }^{336}$ Constitutional Deliberation in Congress, p. 95.

${ }^{337} \mathrm{Na}$ resenha crítica que publicou sobre o livro, Whittington argumenta que a conclusão extraída de casos sobre federalismo, feita por Pickerill, não pode ser generalizada para outras áreas ("James Madison Has Left the Building").
} 
O desafio legislativo contra a decisão judicial é incomum. O parlamento, em regra, prefere não comprar a briga política ou argumentativa. A prática mais corriqueira é o parlamento editar uma lei que se adapta às exigências judiciais. A literatura sobre construção coordenada costuma presumir que qualquer resposta legislativa corresponde a uma rejeição da supremacia judicial, a uma prova de que o legislador pode prevalecer. Pickerill mostra, contudo, que esses estudos fazem vistas grossas para diferentes espécies de resposta legislativa. Ao não olharem para a substância da resposta, perdem o detalhe desse fenômeno. ${ }^{338}$ Há diversas variáveis que impactam o tipo de resposta legislativa. Se os objetivos gerais da política pública podem ser preservados, sem grande prejuízo, a despeito da decisão judicial, o parlamento acomoda-se a uma lei deferente à corte. A longevidade da lei é também relevante para esse fenômeno. Em geral, o parlamento não tem grande interesse em lutar pela sobrevivência de uma lei antiga que não integra a agenda prioritária. ${ }^{339}$

A política pública final, segundo o autor, é produto da interação e da negociação entre os poderes, processo em que há concessões mútuas. A plasticidade e a permeabilidade desse jogo produzem decisões diferentes das que seriam tomadas, isoladamente, por qualquer uma dessas instituições. Não se trata de um jogo de soma zero, com vencedores e perdedores num braço-de-ferro institucional. Consiste, com mais freqüência, numa relação "ganha-ganha", em que ambos os lados têm parte de seu objetivo atendido. Exceto em momentos atípicos, o processo não é o de um choque frontal entre vontades diametralmente opostas e inconciliáveis dadas a priori, uma disputa entre tudo ou nada. ${ }^{340} \mathrm{O}$ cotidiano político é guiado por acomodações. A corte influencia o rumo das decisões parlamentares sem criar um impasse. Não é um “obstáculo insuperável” nem um "salvador do povo". Não consiste num inspetor

\footnotetext{
${ }^{338}$ Ibid, pp. 32 e 56.

${ }^{339}$ A idade da lei, a propósito, é uma variável interessante que traz complicações ao debate normativo sobre e legitimidade democrática da revisão judicial. Supondo que a objeção contra o antimajoritarismo da corte seja plausível, não é tão fácil sustentar o mesmo em relação a uma lei antiga, aprovada por uma "vontade da maioria" de gerações anteriores.

340 "It is difficult to explain congressional responses to judicial review solely as a battle over a priori and unidimensional policy preferences where either judicial supremacy reigns and the Court wins, or Congress overrides or challenges Court decisions in an exercise of coordinate construction and Congress wins" (Ibid, p. 37).
} 
externo à política. ${ }^{341}$ Mais do que um bloqueio, a revisão judicial é um redutor de velocidade, ou mesmo um pequeno desvio do mapa inicial. ${ }^{342}$

Por essa razão, Pickerill percebe que sustentar a igual capacidade de os poderes deliberarem sobre princípio é equivocada. Não cai, no entanto, na convencional defesa de uma superioridade ou exclusividade judicial nessas questões. Prefere sistematizar essas dimensões de deliberação dentro de uma hierarquia não excludente. O legislador primariamente se preocupa com as questões de conveniência da política pública. Não é por isso que considerações de princípio estejam excluídas de sua alçada. Nenhum poder está isento da responsabilidade de boas justificativas constitucionais. Essas, porém, são secundárias dentro do leque de pesos e medidas que contam na decisão parlamentar (o checklist do legislador). ${ }^{343}$ A corte, por sua vez, tem na consideração de princípio sua função primária. Pickerill prefere a idéia de primazia judicial (judicial primacy), um meio-termo entre supremacia e igualdade de funções, como uma melhor maneira de entender o valor desse arranjo. ${ }^{344} \mathrm{O}$ processo real, portanto, estaria numa zona cinzenta entre a imposição da vontade de um só, e a construção puramente igualitária e horizontal da política pública.

As evidências empíricas apresentadas mostram que somente na presença de uma ameaça real de revisão o legislador levou argumentos constitucionais em conta. O congresso, portanto, foi sempre reativo e, mesmo nessas circunstâncias, não promoveu deliberações constitucionais de grande qualidade. Os outros determinantes de seu comportamento continuam sendo prioridade. $\mathrm{O}$ parlamento não tem incentivos para construir um argumento constitucional autônomo. Está sempre voltado a orientar seu posicionamento a partir da jurisprudência da corte. Pickerill retrata um parlamento

\footnotetext{
${ }^{341}$ Ibid, p. 149-152.

342 "While judicial review can be a roadblock to legislation, it is often more of a speed bump or detour" (Ibid, p. 31).

${ }^{343}$ Conforme afirmou um deputado entrevistado por Pickerill quanto à ordem de prioridades levadas em conta em suas decisões: "Policy issues first, how do you get a consensus to pass a bill, six other things, then constitutionality" (Ibid, p. 134).

344 "Judicial primacy means that the Court has the primary institutional responsibility for interpreting the Constitution, and that Congress's motivations and its likelihood of engaging in constitutional construction are limited by the majoritarian and representative nature of the institution. It also recognizes, however, that the Court is not 'supreme' in the sense that it always have the final say and is unaccountable to Congress, or that every constitutional issue is a legal, or justiciable, issue. A theory of judicial primacy appreciates representative policymaking and statute making to be the primary (as opposed to the only) responsibilities of Congress, and independent constitutional evaluation to be the primary (as opposed to the only) responsibility of the Court". (Constitutional Deliberation in Congress, p. 152).
} 
americano em que, nas palavras de Whittington, "James Madison saiu do prédio". Num momento decaído da política, o parlamento não está interessado em debater grandes questões constitucionais com sinceridade. ${ }^{345}$

Para Pickerill, um sistema de separação de poderes é desenhado exatamente para produzir normas jurídicas que reflitam o balanceamento de diferentes instituições. Seria esta, ademais, a demanda de uma "república das razões", uma forma de gerar decisões melhor justificadas e moderadas. ${ }^{346}$ Aqui percebemos o desdobramento normativo do argumento: mais legítima será a revisão judicial quanto mais claro estiver que não houve deliberação constitucional no parlamento. Mais do que um "mal necessário" para proteger as minorias contra abusos de poder, a corte dá uma contribuição peculiar ao infundir na política a dimensão valorativa da constituição. ${ }^{347}$

A corrente apresentada aqui busca construir, poderíamos dizer, uma concepção integral de constitucionalismo, e estimular uma deliberação de qualidade dentro e fora das cortes. A constituição não é, portanto, monopólio das instituições judiciais. O que Tushnet chamou de "distorção da política pública", ${ }^{348}$ outros chamaram de construção coordenada, negociação, acomodação, compromisso e moderação. Enquanto constatação empírica, o fato de que políticas são produto da interação parece incontestável. Resta saber se a presença da corte produz resultados melhores do que sua ausência. $\mathrm{O}$ que ganhamos com e o que perdemos sem a revisão judicial? Para Tushnet, há o risco da distorção, um efeito negativo. Para outros, há uma produção jurídica mais inventiva e atenta a valores constitucionais, uma tecnologia institucional para estimular a prática de justificação.

\section{Barry Friedman: diálogo e o "constitucionalismo popular mediado"}

\footnotetext{
${ }^{345}$ Cf. a resenha crítica escrita por Whittington, "James Madison Has Left the Building”.

346 "In my view, we now have more carefully and thoughtfully drafted legislation that reflects an interinstitutionally collective justification for the legislation, as opposed to having institutional winners and losers in a battle over a priori and unidimensional policy preferences. When bargaining among multiple institutions results in a more comprehensive justification for law and policy, the normative preference for a republic of reasons has been more fully realized" (Constitutional Deliberation in Congress, p. 60; cf. também p. 131)

347 "The Court's constitutional decisions may not be the last word in the judicial supremacy sense, but they have an important and significant role in infusing constitutional debate into the lawmaking process and in shaping the language and scope of legislation" (Ibid, p. 24).

${ }^{348}$ Mark Tushnet, "Policy Distortion and Democratic Debilitation".
} 
A lei não é sempre majoritária. A revisão judicial não é sempre contramajoritária. ${ }^{349}$ Ao contrário, raramente o é. Ela cumpre papel singular, mas não tem como ser explicada nos termos de uma oposição entre maioria e minoria. ${ }^{350} \mathrm{Tal}$ hipótese é implausível e contra-factual. ${ }^{351}$ Essas três teses provavelmente resumem o coração do argumento de Barry Friedman, espalhado numa série de artigos publicados nos últimos vinte anos.

Para este autor, a tradição hegemônica da dificuldade contra-majoritária faz duas suposições que, na melhor das hipóteses, são superestimadas, e na pior, simplesmente equivocadas: primeiro, que existe uma vontade da maioria identificável e fixa, a qual o legislador espelha, e da qual a corte se distancia; segundo, que a corte tem a última palavra. ${ }^{352}$ Tais aparências distorcem o que efetivamente há. Friedman propõe substituir essas duas suposições por três idéias que, segundo ele, são mais compatíveis com a realidade: o sistema de governo não representa, propriamente, a maioria, mas escuta e integra vozes de diferentes grupos; o texto constitucional é flexível o suficiente para acomodar diversas interpretações; o processo de interpretação constitucional não é estático, mas dinâmico, e consolida uma interpretação diferente a cada momento. Essas três características fomentariam uma interação vigorosa no cotidiano constitucional. ${ }^{353}$

A rejeição de uma vontade da maioria identificável e estável já apareceu no capítulo 2 dessa tese, por ocasião da defesa da última palavra judicial. Friedman endossa essa constatação, e não se impressiona com reivindicações de prevalência da

\footnotetext{
349 "Although a great deal of work has been devoted in recent years to the notion that the legislative process is not as majoritarian as we idealize, little focus has been given to the other side of the equation. (...) Measured by a realistic baseline of majoritarianism, courts are relatively majoritarian". ("Dialogue and Judicial Review", p. 586)

${ }^{350} \mathrm{Tal}$ constatação poderia inspirar uma forma alternativa de classificar as teorias da revisão judicial: de um lado, as teorias que a pensam nestes termos de maioria e minoria, e, de outro, as que pensam de algum outro modo. Por esse critério, chagaríamos provavelmente a uma sistematização diferente da proposta nesta tese.

351 "Most legal scholarship is focused in a counter-factual: why do we tolerate counter-majoritarian courts? Courts do occasionally interfere with a clear majoritarian consensus, and even more rarely they frustrate that consensus for a long period of time". ("The Counter-Majoritarian Problem and the Pathology of Constitutional Scholarship", p. 937).

352 "Because the judicial word is not the last word, the countermajoritarian difficulty loses force" ("Dialogue and Judicial Review", p. 644). Em outra expressão: "fallacy of judicial finality" (Ibid, p. 654).

${ }^{353}$ Cf. "Dialogue and Judicial Review", pp. 583, 615, 629.
} 
vontade da maioria, um fenômeno fluido, efêmero, em constante mutação, com variadas intensidades. Trata-se, se não de um mito, de uma qualidade menos central da democracia. ${ }^{354}$ Nenhum poder é perfeitamente majoritário. ${ }^{355} \mathrm{O}$ que existe, para Friedman, é uma "Babel" de vozes que se chocam, se acomodam e se transformam, em progressão infinita. Aos poderes cabe negociar e definir uma direção em meio a essa pluralidade. ${ }^{356}$ “O que o parlamento tem que a corte não tem?" ${ }^{357}$ Recorrer a noções de maioria para responder a essa pergunta, implícita nas investidas da "dificuldade contra-majoritária", só faz induzir novas confusões.

Em relação à segunda suposição, Friedman desenvolve um longo argumento. Mescla observações da ciência política empírica sobre a decisão judicial com a proposta de outra função para o controle de constitucionalidade - a de facilitador e interlocutor num diálogo permanente. ${ }^{358}$

Há dois sentidos em que uma decisão pode ser considerada a última palavra: no caso específico e no tema geral. ${ }^{359}$ Em relação ao caso, o judiciário precisa de cooperação de outros agentes para implementar suas decisões e, portanto, não decide o que quer. Essa observação não é trivial e mereceria desdobramentos que verificassem sua acuidade, mas, para os fins dessa tese, interessa-me a segunda dimensão. Nesta, parece claro que a decisão judicial está longe de representar a última voz. Friedman recorre ao caso Roe v. Wade para exemplificar essa idéia. A miopia causada pela dificuldade contra-majoritária veria a decisão de Roe como o fim da história sobre o regime jurídico do aborto. Porém, foi apenas o começo, e catalisou décadas de debate e de renovados testes políticos à decisão. ${ }^{360}$ Roe teria representado uma nova era no debate. Num momento em que a inércia legislativa beneficiava opositores ao aborto e boa parte da população não tinha posição formada, a corte teria forçado a sociedade a pensar. Três décadas depois, poder-se-ia dizer que a maioria da

\footnotetext{
354 "Although democracy has something to do with majority rule, in a representative system like our own majority rule is purely a question of degree". ("Dialogue and Judicial Review", p. 587).

${ }^{355}$ Cf. "Dialogue and Judicial Review”, p. 614.

${ }^{356}$ Cf. "Dialogue and Judicial Review", pp. 643 e 657.

${ }^{357}$ Cf. "Dialogue and Judicial Review", p. 588

358 "This process of constitutional interpretation hardly pits the court against the people. Rather, the court mediates the views of various people. The process is interactive (...) Simply put, our process of constitutional interpretation is a dialogue". ("Dialogue and Judicial Review", p. 654)

${ }^{359}$ Cf. "Dialogue and Judicial Review", p. 644.

${ }^{360}$ Cf. "Dialogue and Judicial Review", pp. 647, 660 e 661.
} 
sociedade americana refletiu e se posicionou a respeito, e continua a debater e a criar novos desafios.

A corte, eventualmente, diz que sua palavra é a última. Todavia, enquanto houver desacordo, a deliberação política continuará a ocorrer, com grupos se mobilizando para contestar a decisão. ${ }^{361}$ Como a constituição é um texto aberto e flexível, interpretações são contingentes e sujeitas a mudanças constantes. Não serão aceitas como corretas para sempre. Há um contínuo percurso de atribuição de novos significados. ${ }^{362}$ Seria um processo de idas e vindas, em que a corte devolve o tema para a sociedade e para os outros poderes, e vice-versa. Na metáfora de Friedman, seria como parceiros numa partida de tênis, que rebatem a bola ininterruptamente. ${ }^{363}$

Os juízes estão constrangidos pelo sistema político que os circunda. Pensar no papel do juiz exclusivamente a partir de regras de interpretação teria criado uma grande miopia cognitiva. ${ }^{364}$ Há muitos outros elementos que limitam o seu poder. Friedman os chamou de "círculos concêntricos de influência". ${ }^{365}$ Quatro seriam os níveis principais, que se combinam de maneira peculiar em cada situação: primeiro, o juiz está imerso em uma interação estratégia com outros juízes dentro de um colegiado (espaço em que não há apenas deliberação ou agregação, mas também barganhas e acomodações); segundo, pelas pressões impostas por instâncias inferiores do judiciário; terceiro, pelos outros poderes; e, finalmente, pela opinião pública. Diferentes são os incentivos para atentar-se a cada um desses limites. Credibilidade institucional, reputação e risco de desobediência são os principais deles.

\footnotetext{
361 "Yet, absent agreement, finality will not occur. (...) This lack of finality seems the inevitable result of the general indeterminacy of the constitution's text". ("Dialogue and Judicial Review", p. 648-649)

362 "The court is free to change its mind. The people are free to disagree with the court. The court is free to disagree with the people. The members of the court are free to, and usually do, disagree with one another. As disagreement occurs, the document will take on new meanings". ("Dialogue and Judicial Review", p. 651)

363 "Does this give the courts the last word? As I explain at length elsewhere, it seems not. (...) rights rarely are trumps. And so, what one gets, is a constant volleying back and forth on the respective weighing of rights interests and powers interests. And through this volleying, it seems to me, is how we most likely are to arrive at a reasonable accommodation. But the whole game falls apart if courts simply abandon their side of the volleying" ("Trumping Rights", p. 462). "Courts serve as society's tennis partner, always volleying the ball back" ("Dialogue and Judicial Review", p. 669).

364 "Normative theorists obviously can argue that what judges are doing is not what they ought to do. But they also must have a story about why judges might act differently or what will make them do so". ("The Politics of Judicial Review", p. 279)

${ }^{365}$ No original: "concentric circles of influence and constraint" ("The Politics of Judicial Review", p. 263).
} 
Correspondem a constrangimentos que juízes necessariamente enfrentam, e que teorias da interpretação ignoram.

A teoria positiva da qual Friedman se alimenta busca entender o que efetivamente motiva os juízes, o que eles maximizam. ${ }^{366}$ Percebe que, além do próprio direito, e também de valores e ideologias pessoais, os elementos políticos enumerados acima delimitam os raios de ação possível da decisão judicial. Ao contrário do que defendem teorias normativas, juízes têm esferas de autonomia menores do que se imagina. ${ }^{367}$ Hércules seria o epítome da teoria normativa desconectada da realidade. Os constrangimentos que enfrenta são aspectos dados do sistema constitucional. Ele não tem escolha, senão levá-los em conta. Hércules não age sozinho. Para obter obediência dos outros agentes políticos, ele precisa calcular como eles reagirão. ${ }^{368}$ Teorias normativas estariam obcecadas em limitar o poder dos juízes sem perceber que ele já está limitado por diversas fontes. Cortes não estão no vácuo ou numa torre de marfim. Precisam de cooperação.

A dificuldade da colaboração inter-disciplinar que Friedman diagnostica se deve à recusa de teóricos normativos a aceitar que as principais forças que influenciam juízes são políticas. Insistem no velho hábito da separação absoluta entre política e direito: o juiz deve decidir somente de acordo com este, e estar insulado daquela. ${ }^{369}$ Criou-se o mito de que há uma instituição distante da política. Essa relação, porém, é de interdependência. Juízes são produtos da sociedade em que vivem e são influenciados pelos jogos de forças políticas e ideológicas dessa sociedade. ${ }^{370}$

A corte desempenha, apesar de todos esses limites, papéis relevantes para a intensidade e racionalidade do diálogo. Ela coleta argumentos, sintetiza-os, pauta a discussão, faz escolhas, direciona, catalisa, provoca e modera. ${ }^{371}$ Perturba e causa

\footnotetext{
${ }^{366}$ Cf. "The Politics of Judicial Review", p. 270.

${ }^{367}$ Cf. "The Politics of Judicial Review", p. 331.

368 "That Hercules is a judge and not just any other political actor is a fact of enormous significance; still, Hercules must do his judging in a political world". ("The Politics of Judicial Review", p. 260)

369 "Old habits die hard" "“The Politics of Judicial Review", p. 259).

370 "When courts are discussed in countermajoritarian terms I often get a funny picture of judges as aliens come from Mars to impose Martian values upon an unwilling electorate" ("Dialogue and Judicial Review", p. 615). "Judges do not live in a cocoon; they are of this world" ("Mediated Popular Constitutionalism", p. 2612).

371 "Dialogue and Judicial Review", p. 668.
} 
ruídos no status quo. As partes se influenciam mutuamente e mudam suas preferências. A corte interage, mas não é a única voz. Não se trata de um processo em que a corte fala e o parlamento escuta, em que um manda e o outro obedece. ${ }^{372}$ Assim como os outros poderes, a corte é um participante ativo do debate. Como tal, posiciona-se sobre o significado da constituição, mas é capaz de fazer mais do que isso. Ela também estimula um diálogo social expandido. Ao optar por uma interpretação, a corte desperta a discussão. Este é o resultado inevitável de uma decisão constitucional controversa, e a corte tem condições de conduzi-lo e influenciá-lo, de esfriá-lo e esquentá-lo. ${ }^{373}$ Daí o caráter dinâmico da interpretação. ${ }^{374}$

Friedman propõe, nessa perspectiva, que a separação de poderes seja percebida como "cooperação de poderes". Não se trata de uma visão ingênua que esconde o conflito e o desacordo, mas de uma sensibilidade para a complexidade da interação. Nossa tendência de pensar a separação de poderes como luta adversarial teria ofuscado a forma como as políticas públicas de fato emergem. $\mathrm{O}$ autor lança mão da imagem de uma porta com várias trancas: cada poder tem uma chave. A corte cumpre uma função, mas não abre a porta sozinha. ${ }^{375}$

Apesar de salientar diversas vezes que seu ponto de partida consiste numa descrição da revisão judicial, Friedman não deixa de fazer uma defesa dessa instituição (ainda que comedida nos adjetivos). Esta seria a sua "virada normativa" (normative turn). ${ }^{376}$ Sem fazer promessas messiânicas, mostra que a corte pode cumprir um papel institucional virtuoso. Formular prescrições normativas, na sua versão, precisa levar em conta as informações empíricas. Estabelece as condições para

\footnotetext{
372 "Dialogue and Judicial Review", p. 663.

373 "Dialogue simply is inevitable". ("Dialogue and Judicial Review", p. 680)

374 "Change is both healthy and inevitable. In reality, the process of constitutional interpretation is dynamic, not static. (...) Moreover, such dynamism is critical to the success of the venture. (...) Judicial decisions are experiments, and experiments rarely are completely successful". ("Dialogue and Judicial Review", p. 652)

375 "Separation of powers - and other structural limitations - may just as well be thought of as a 'cooperation of powers'. Each branch or governmental unit has a special role to play, but goals cannot be advanced unless the branches work together at some extent. Picture a door secured with several locks, the key to each in another's hands. If the door is to be unlocked, the keyholders must reach agreement to do so. Under this 'cooperation of powers' system, the best decisions are those made when the branches of government agree. That is not to say every branch and unit will get what it wants (...); indeed, the point is that the branches must negotiate and compromise" ("When Rights Encounter Reality", p. 772).

376 "Prompting, maintaining, and focusing this debate about constitutional meaning is the primary function of judicial review. (...) Although this largely has been a positive account, it is worth making the normative turn" ("The Importance of Being Positive", p. 1296-1297).
} 
a conciliação do positivo com o normativo: "Ser não implica em dever ser, mas dever ser supõe poder ser". ${ }^{377}$ Os limites da teoria normativa seriam "as realidades imutáveis do mundo". ${ }^{378}$ Ela precisaria circunscrever-se ao "domínio do possível” e estar atenta ao contexto em que tais prescrições teóricas se aplicam. ${ }^{379}$

Passar a fazer teoria normativa sem o embrulho da dificuldade contramajoritária e com uma melhor noção do que constrange, realisticamente, o comportamento judicial, liberaria juízes de uma missão que eles não poderiam cumprir, por mais bem intencionados que fossem. ${ }^{380}{ }_{-}^{381}$ Se as cortes estão sujeitas a todo esse conjunto de limites, o que podemos esperar ou temer? A partir desses fatos, pode-se contar alguma história com um bom apelo normativo? Essa instituição adiciona algum valor? ${ }^{382}$

Friedman oferece o conceito de "constitucionalismo dialógico" ou de "constitucionalismo popular mediado" para enfrentar essas questões. ${ }^{383}$ Haveria um paradoxo entre dois objetivos que demandamos da democracia: que os poderes reflitam o sentimento popular, mas que também o liderem na persecução de alternativas e caminhos inovadores. ${ }^{384} \mathrm{~A}$ resposta para o paradoxo está na forma como o sistema constitucional funciona: os poderes se aproximam e se distanciam da

377 "Is does not imply ought, but ought implies can" ("The Politics of Judicial Review", p. 261).

378 "The immutable realities of the world are the parameters within which normative theory must operate. Ought does imply can" ("Dialogue and Judicial Review", p. 331).

379 "It is being normative, with an eye out for facts about the world in which normative arguments operate" ("The Counter-Majoritarian Problem and the Pathology of Constitutional Scholarship", p. 952).

380 "This question has enormous normative significance (...). If, for example, the Supreme Court is constrained by political actors, then normative theories that support judicial review as protecting minority rights against a wilful majority at least require nuance if not rethinking". ("Taking Law Seriously", p. 264)

381 "Attention to positive scholarship does not deny an important role for thinking in normative terms, and perhaps not even in ideal ones. Indeed, a central point here, discussed below, is that positive scholarship can be liberating for normative theory. But the normative endeavor must play by some rules as well. Especially when it specifies the operation of institutions, it must deal in the realm of the possible". ("The Politics of Judicial Review", p. 331)

382 "Judicial review can be understood as attractive precisely because it is embedded in politics, but is not quite of it. Politics and law are not separate, they are symbiotic. It would be remarkable to believe judicial review could operate entirely independent of politics or would be tolerated as such. Nor is it clear that this would be desirable given social and constitutional commitments to accountability and checks and balances. The practice of judicial review is valuable in that it serves as one more counterweight, like many others in our constitutional system. Moreover, because judicial decisions about constitutional law are sticky - they cannot be overturned at the drop of a hat - judicial review serves to channel and foster societal debate about constitutional meaning". ("The Politics of Judicial Review", p. 333)

${ }^{383}$ Cf. "Dialogue and Judicial Review", p. 617, e "Mediated Popular Constitutionalism", p. 2599.

${ }^{384}$ Cf. "Leadership and Majoritarianism: A Response", p. 8-10. 
opinião popular, alternadamente. Há ciclos de aproximação e de afastamento. Nos poderes eleitos, o ciclo de alinhamento é imposto a cada nova eleição. Tem, portanto, uma periodicidade fixa. É mais regular e controlável. A corte, por sua vez, tem uma ciclotimia mais instável e alongada, passa por ondas de "liderança" e de "majoritarismo", sem periodicidade certa. Pode ser visionária e reacionária. Oscila entre um papel ativo e passivo. ${ }^{385}$ É fundamental que não seja somente um ou outro: se for só majoritária, perderá sua credibilidade e função crítica e dialógica; se for só contra-majoritária, transbordará o limite da liderança e provavelmente não conseguirá existir por muito tempo. A corte de Warren, para Friedman, teria ensinado os "limites da liderança judicial". ${ }^{386}$

Essa ciclotimia ajuda a resolver o paradoxo. O desenho institucional cria a ocasião para o afastamento e o diálogo é valioso porque estimula a divergência. Por meio dessa "tensão dinâmica", novas interpretações constitucionais florescem. Elas refletem, em alguma medida, a vontade popular. Diferentemente do que propõem os defensores do constitucionalismo popular, porém, a relação entre tais interpretações e a vontade popular não é direta, mas mediada por uma lenta interação entre cortes e opinião pública. O seu laço é mais frouxo. A corte não é servil à opinião pública todo o tempo. Contudo, tampouco é absolutamente resistente. Convergem, mas somente no longo prazo. ${ }^{387}$ A corte conquista um estoque de apoio difuso que a preserva de eventuais decisões individuais impopulares. ${ }^{388}$ Esse “capital", entretanto, não é infinito nem estático, e ela somente será tolerada dentro de certos limites.

Tal natureza mediada é importante, pois a adjudicação constitucional não pode atender a qualquer preferência ou desejo popular imediato. Para que não se converta em mera "política normal", o ritmo da convergência entre revisão judicial e a vontade popular precisa incentivar a busca por princípios mais profundos, por valores de base

\footnotetext{
385 "The judiciary can be at times visionary, and at times reactionary, but never too much of either. (...) The judiciary is both visionary and reactionary simply because it is always somewhat out of sync with the waves or more political branches - always inching ahead of lagging behind. The divergence between popular sentiment and the judiciary is what makes the dialogue work. (...) Judicial action creates the dynamic tension that moves the system of constitutional interpretation along". ("Dialogue and Judicial Review, p. 678)

${ }^{386}$ Cf. "Leadership and Majoritarianism: A Response", p. 11.

387 "But the public may well support a system that gives it what it wants much of the time, even if not all the time". ("Mediated Popular Constitutionalism", p. 2606)

388 "On balance then, what seems to be the case, is that over time the Court somehow builds up a store of diffuse support, which is not easily eliminated by negative reactions to individual decisions" ("Mediated Popular Constitutionalism", p. 2627; cf. também "The Politics of Judicial Review", p. 326)
} 
que o povo aceita ao longo do tempo e após reflexão mais sóbria. A corte se resguarda ao engajar-se no diálogo. Sem participar desse debate de modo razoável, não sobreviveria à hostilidade pública. ${ }^{389}$

O sistema político confere à corte um mecanismo flexível para seguir a opinião pública ao longo do tempo. ${ }^{390} \mathrm{Em}$ vez de alienar, a descrição dialógica integraria a corte no processo de construção de significado da constituição. ${ }^{391}$ Descrições convencionais ignoram as sutilezas do sistema e pressupõem, sem maiores qualificações, a dessintonia entre a corte e a maioria. De tempos em tempos, essa suposição pode ser verdadeira no que diz respeito a preferências imediatas. A possibilidade da dissonância provisória, porém, é justamente o que protege os princípios de fundo do sistema constitucional. ${ }^{392}$ Apesar dos diferentes ciclos de cada poder, há tempos de nítida congruência. Nessas ocasiões, os poderes conseguem promover, juntos, mudanças de alto impacto. Esse é o motor da separação de poderes, um sistema que está sempre em movimento, e nunca se congela. ${ }^{393}$

Após essa longa reformulação do problema, Friedman localiza, enfim, qual seria a questão normativa a merecer esforço teórico útil. Se, por um lado, diálogo é inevitável, há que se forjá-lo do modo mais "aberto, vibrante e efetivo" possível. 394 Para tanto, deve-se promover o balanço ótimo entre os dois pólos constantes dentro dos quais a corte se movimenta: majoritarismo e liderança, alinhamento e dissonância, dinamismo e última palavra (finality). ${ }^{395}$ Dito de outro modo, deve-se buscar balancear, de um lado, separação e independência de poderes e, de outro, freios e

\footnotetext{
389 "Because courts, including the Supreme Court, do not get everything right the first time, or even the second or third time, it helps to have some interplay - to debate things" ("When Rights Encounter Reality", p. 776-777).

390 "The people will follow judicial decrees so long as the judges seem right. When the judges no longer appear to be correct, the people will press for judicial change. Intuitively, at least, the judges know it". ("Dialogue and Judicial Review", p. 677)

391 "Courts are a vital functioning part of political discourse, not some bastard child standing aloof from legitimate political dialogue" ("Dialogue and Judicial Review", p. 581).

${ }^{392}$ Cf. "Dialogue and Judicial Review", p. 674.

393 "Politics tends to move in cycles; people will favor one approach and then, after a time, favor a change". ("Dialogue and Judicial Review", p. 677)

394 "Approaching the question in dialogic terms, rather than in terms of the countermajoritarian difficulty, should inspire a discussion of how to make the dialogue more open, more vibrant, and more effective" ("Dialogue and Judicial Review", p. 671).

${ }^{395}$ Essa é uma questão a ser tratada no capítulo 6. Proponho, na linha do Friedman, que essas duas dimensões não se opõem e não se alternam, mas co-existem. O desafio é encontrar o balanço entre diálogo e última palavra, ou seja, o cálculo do grau de resistência à mudança da última palavra provisória, do grau de estabilidade e provisoriedade.
} 
contrapesos. ${ }^{396} \mathrm{O}$ gerenciamento virtuoso desses ciclos seria o grande desafio das investigações normativas futuras. Ademais, como o poder judiciário está constrangido pela política e pela opinião pública, a audiência adequada para essa renovada teoria normativa não deve ser o próprio judiciário, mas a opinião pública. Direcionar a teoria normativa aos juízes revela a ingênua separação entre política e direito. ${ }^{397}$

Em síntese, pode-se dizer que Friedman busca cumprir três missões: apresentar um manifesto metodológico pela integração e colaboração interdisciplinar no estudo das cortes; mostrar o papel singular de catalisador do diálogo que a corte desempenha; verificar as implicações normativas dessa perspectiva mais realista.

Em relação à primeira missão, defende um caminho de duas mãos: teorias normativas da revisão judicial devem aprender com as lições produzidas pelas pesquisas empíricas sobre o comportamento judicial e entender que o juiz constitucional está, inexoravelmente, mergulhado num ambiente político; as teorias positivas, por sua vez, devem levar o direito a sério, e não fazer suposições unicausais simplistas para entender o poder judiciário, como se este fosse mera extensão das instituições eleitas e agisse conforme as mesmas variáveis. Em suma, sugere uma teoria que integre direito e política. ${ }^{398}$ Mais do que isso, que articule o projeto normativo e o positivo, após décadas de separação decorrente de extrema rigidez disciplinar e de compromissos ideológicos. ${ }^{399}$ Denuncia a patologia da tradição que aprendeu a tomar como premissa obrigatória a "dificuldade contra-majoritária", e teria entorpecido a análise. Tal premissa, em termos empíricos, seria falaciosa, apesar de ter se tornado obsessão da reflexão constitucional. ${ }^{400}$

\footnotetext{
${ }^{396}$ Friedman aponta para meta de encontrar esse "balanço" em vários textos: "Finality would curtail the evolution of our constitution; dynamism encourages it. Constitutional meaning changes because people disagree about what the text means. Dynamism is to be encouraged, for the dynamic process helps formulate the interpretation of our fundamental charter. Of course, there is a balance to be struck between dynamism and finality" ("Dialogue and Judicial Review", p. 652); "The Constitution does grant Hercules a certain degree of independence, but it also embeds him in politics. This is no accident: The Constitution represents a deliberate balance between, on the one hand, separation and independence of the branches and, on the other, accountability and the idea of checks and balances" ("The Politics of Judicial Review", p. 260); "The trick is striking a balance between too little and too much judicial responsiveness" ("Mediated Popular Constitutionalism", p. 2599); "Ultimately, however, the question of how much slack there should be is a normative one" ("The Counter-Majoritarian Problem and the Pathology of Constitutional Scholarship", p. 949).

397 "The Politics of Judicial Review", p. 334-335.

${ }^{398}$ Cf. "The Politics of Judicial Review”, pp. 262 e 269.

${ }^{399}$ Cf. "Taking Law Seriously", p. 262.

400 "We have been haunted by the 'countermajoritarian' difficulty far too long" ("Dialogue and Judicial Review, p. 578).
} 
Em segundo lugar, como desdobramento de seu manifesto, o autor mostra que cortes raramente decidem contra a maioria (nas circunstâncias em que "vontade da maioria" pode fazer algum sentido). Freqüentemente, operam em sintonia com a opinião pública. Essa sintonia, porém, não é perfeita e está sujeita a ciclos de convergência e divergência que seguem um passo diferente das instituições eleitas. Constata que a corte não é o agente todo poderoso que a tradição nos teria feito acreditar, e percebe que ela cumpre papel distinto: é interlocutor e promotor de um diálogo entre a sociedade e as instituições políticas. É uma instituição que não atua livre de quaisquer constrangimentos. Estes, porém, não são propriamente derivados de teorias normativas da interpretação, mas de uma rede mais complexa de determinantes políticos do comportamento judicial. Essa é a tensão implícita no pensamento de Friedman: por um lado o diálogo é inevitável e apresenta limites inerentes e sistêmicos à corte; por outro, a corte é um participante ativo, que influencia o diálogo e pode conduzi-lo para direções variadas. ${ }^{401}$

Finalmente, dentro dessa cruzada metodológica, Friedman sinaliza para um retorno à teoria normativa, ao defender a revisão judicial como uma opção valiosa que contribui para a legitimidade do regime. Este passo é ainda embrionário, tentativo e vacilante. Quer uma teoria normativa repaginada e plausível, sensível às lições da história, atenta às instituições como elas são; uma teoria que leve em conta a complexidade das motivações por trás da decisão judicial. Essa pretensão envolve um balanço difícil entre, de um lado, conceder e, de outro, duvidar e resistir ao diagnóstico sobre o "mundo real".

Tal diagnóstico, poderíamos objetar, não goza de neutralidade. No limite, a teoria normativa perderia seu papel crítico e transformador, e se curvaria à naturalização de certa realidade assumida como um dado imutável. Apesar dessa suspeita, parece-me plausível o reclamo pela necessidade de prestar atenção às condições institucionais e aos incentivos que elas geram para o comportamento dos agentes que dentro delas operam. Fazer vistas grossas a esse cenário, de fato, teria pouco a contribuir para o aperfeiçoamento da revisão judicial e para o mapeamento de caminhos teóricos que possam orientar a conduta do juiz.

\footnotetext{
401 “The dialogic view simply accepts what judges do" ("Dialogue and Judicial Review”, p. 671).
} 
Sua mensagem, provavelmente, é que não devemos superestimar um problema menor e ocasional, com pouca resistência ao tempo. Seria preciso transcender essa discussão e descobrir se a revisão judicial, no agregado, representa um ganho ou uma perda. ${ }^{402} \mathrm{O}$ fato de a decisão da corte não fugir do "aceitável" no atacado ou no longo prazo, não significa que ela não possa ser danosa à democracia no varejo ou no curto prazo. Friedman deixa isso em aberto.

É curioso observar como algumas de suas idéias aproximam-se das de Bickel. Ironicamente, entretanto, seu ponto de partida consiste num ataque à tradição da "dificuldade contra-majoritária". Isso provavelmente mostra tensões na obra de Bickel (ou ao menos uma interpretação parcial feita pela tradição, que pegou emprestado aquela expressão famosa sem considerar o resto do seu pensamento).

Qual seria a diferença de Friedman para a maioria das outras teorias do diálogo? A primeira delas é o rechaço da "dificuldade contra-majoritária". ${ }^{403}$ Compartilha, além disso, de elementos da "construção coordenada", mas soma a ela, mais enfaticamente, a opinião pública. Sua abordagem transcende, portanto, as instituições e funde as esferas formal e informal da política na explicação do diálogo.

Da leitura de Friedman, pode-se inferir que o fato institucional novo trazido pela revisão judicial não é tanto criar uma força anti-majoritária (com todos os melindres que isso desperta na sensibilidade de alguns defensores da democracia). Seria, ao contrário, cobrar o exercício de responsabilidade pelos outros agentes políticos. É um ator diferente do legislador porque suas condições institucionais favorecem um ritmo diferenciado, um desenvolvimento interpretativo mais pausado, um obstáculo contra impulsos imediatos. A corte tem um papel pró-ativo a cumprir, mas, ainda assim, modesto em comparação a versões messiânicas convencionais. Ela passa, sob esse novo pano de fundo, a ser mais palatável e plausível, pois não tem a

\footnotetext{
402 "We should not (necessarily) junk the entire venture, at least until we have determined - as the first project is designed to do - what it adds or detracts". ("Birth of an Academic Obsession: The History of the Countermajoritarian Difficulty, Part Five", p. 258-259)

${ }^{403}$ Preocupação que está presente no debate canadense (Hogg e Hiebert, p. ex.), conforme veremos adiante.
} 
responsabilidade de salvar a democracia. ${ }^{404}$ Investigações positivas nos teriam mostrado que tanto o temor de subversão democrática quanto a esperança salvacionista em relação à revisão judicial estariam descalibrados. ${ }^{405}$

Não é a revisão judicial que conseguirá travar uma ampla e consistente mobilização majoritária, caso se esteja preocupado com isso. A revisão judicial contribui, porém, para combater a inércia, a omissão e a indiferença legislativa, a reduzir o afastamento e a dissonância entre representante e representado. Ela tem a capacidade de subverter o status quo, mas não de maneira revolucionária. A ela não basta encontrar a decisão certa de princípio. Vislumbrar alianças é fundamental para uma instituição que não tem nem a espada nem o cofre, na expressão de Hamilton a que Friedman recorre com freqüência. É um ator dentro do jogo político, e precisa atrair aliados.

\subsection{O debate canadense: a Carta de Direitos e a Seção 33}

A Carta de Direitos e Liberdades (Charter of Rights and Freedoms), de 1982, é um divisor de águas na história constitucional canadense. Até então, o Canadá vivia sob a égide de uma "declaração legislativa de direitos" (statutory bill of rights), de 1960, instrumento sem status constitucional e tido como pouco efetivo. Essa estratégia anterior de institucionalização de direitos teria gerado uma postura tímida dos juízes, ainda muito apegados a uma leitura dos direitos pelas lentes da soberania do parlamento, pois este não poderia sofrer invalidação de seus atos em virtude de inconstitucionalidade.

A Carta coloca os direitos num novo plano hierárquico e reposiciona o judiciário na estrutura de poderes. Não foi uma mudança imune a críticas. Representou a vitória intelectual daqueles que consideram a revisão judicial necessária para a concretização de direitos na democracia. Segundo seus defensores, a Carta acrescenta uma nova linguagem, até então tímida, aos debates coletivos. A

\footnotetext{
404 "The problem of the countermajoritarian difficulty is that it overstates the role of courts and thus understates society's responsibility. My point is that we should neither understate nor overstate the role of courts; we must account accurately for the critical role of the rest of society, the people" ("Dialogue and Judicial Review", p. 682).

${ }_{405}$ "The fact of constraint calls this story into question" ("The Politics of Judicial Review", p. 317; cf. também p. 309)
} 
transição do status legislativo para o constitucional geraria maior potência para infundir uma cultura de direitos no Canadá. ${ }^{406}$

Não se tratou, contudo, de mera importação de um modelo canônico de controle de constitucionalidade. Em razão da preocupação com a "dificuldade contramajoritária”, criou-se um modelo com uma característica singular. A Seção 33 deu ao parlamento o poder de recusar que uma lei aprovada seja objeto de revisão judicial. Esse ato tem duração de 5 anos, prazo que pode ser renovado pelas legislaturas seguintes. ${ }^{407}$ Para aqueles que temiam a supremacia judicial, concedeu-se uma válvula de escape que institucionalizou a resposta legislativa: se o legislador não aceitar a posição da corte, ele tem condições de impor-se. Apesar de praticamente não utilizada nesses mais de 25 anos de existência da Carta, talvez pelo ônus político e simbólico que ela traz ao legislador, a Seção 33 é elemento que integra a forma de a teoria constitucional canadense perceber o diálogo, pois ela o teria oficializado $\mathrm{e}$ facilitado. ${ }^{408}$

\section{Diálogo como "seqüência legislativa" e seus críticos}

Foi somente em 1997, com um artigo seminal de Peter Hogg e Alison Bushell, que se inaugurou o debate canadense nos termos de "diálogo". ${ }^{409}$ Os autores fizeram um levantamento empírico de todos os casos em que, nesses 15 anos, a corte declarou

\footnotetext{
${ }^{406}$ A literatura sobre o papel da Carta de Direitos na cultura política canadense é prolífica. Uma boa porta de entrada é Janet Hiebert, Charter Conflicts: What is Parliament's Role?.

${ }^{407}$ A Seção 33 é conhecida como a "notwithstanding clause" ou "override". A Seção 1, conhecida como "limitation clause", é também tida como central na idéia de diálogo no Canadá. Trata-se de um dispositivo que permite ao legislador restringir direitos de acordo com limites razoáveis e justificáveis. É curiosa a celebração da novidade desse dispositivo, afinal a dogmática constitucional sempre trabalhou com base na premissa de que direitos não são absolutos e que, portanto, estão sujeitos a limites. A possibilidade da limitação seria uma cláusula necessariamente implícita numa declaração de direitos. De qualquer modo, no Canadá, essa cláusula parece ter sido importante para disciplinar uma linguagem de justificação dos limites aos direitos mais aberta ao balanceamento, relativizando a idéia rígida de direitos como "trunfos". É a opinião de Janet Hiebert: "The inclusion of an explicit limitation clause is more conducive to a rigorous and open debate about the merits and justification of policy choices than if the Charter was silent on the question of limitations" (Limiting Rights: The Dilemma of Judicial Review, p. 153).

${ }^{408}$ Conforme Stephen Gardbaum, essa foi a pretensão da Seção 33: "In this way, beneficial dialogue between courts and legislatures would replace the American model's judicial monologue". Mas ele argumenta que, pelo seu escasso uso, a Seção 33 não teria conseguido criar efetivamente um modelo mais fraco de revisão judicial (“The New Commonwealth Model of Constitutionalism", p. 23).

409 "The Charter Dialogue Between Courts and Legislatures (Or Perhaps the Charter of Rights Isn't Such a Bad Thing After All)".
} 
a inconstitucionalidade de uma lei. Buscaram, então, verificar se houve e qual teria sido a reação do legislador.

Descobriram que na maioria absoluta dos casos o parlamento respondeu por meio de uma "seqüência legislativa" (legislative sequel); que essa resposta foi geralmente imediata; que os legisladores se engajaram na linguagem da Carta (por meio de preâmbulos e declarações de princípios); e que, mesmo quando a lei não é declarada inconstitucional, o debate público despertado pode levar o legislador a atentar-se para problemas na lei e eventualmente a alterá-la. ${ }^{410} \mathrm{O}$ silêncio legislativo, portanto, foi a exceção. A intensificação de uma interação argumentativa, a regra.

Consideram que toda resposta legislativa, quando feita como reação consciente à decisão judicial, mesmo que aquiesça à posição da corte, exemplifica um tipo de diálogo. Discordam de que a adesão à corte não o configure, pois acreditam que o acordo e o convencimento são sempre um resultado possível desse processo. Não se pode, por isso, presumir uma deferência passiva nessas circunstâncias. Quando a decisão judicial deixa em aberto a possibilidade de resposta legislativa, seria pertinente caracterizar o processo como um diálogo. Nesses casos, a revisão judicial não é um veto, mas o começo de uma comunicação inter-institucional a respeito de como conciliar direitos individuais com os objetivos de políticas econômicas e sociais. ${ }^{411}$ Provoca-se um debate público qualificado, que não ocorreria sem a decisão judicial. A corte força um tema que não apareceria na agenda legislativa. ${ }^{412} \mathrm{O}$ legislador, por sua vez, não se vê amarrado, pois pode perseguir os mesmos fins por outros meios. ${ }^{413}$ Nos raros casos em que isso não ocorre, pode lançar mão da Seção 33 ou, como o fez algumas vezes, insistir com a mesma lei, mas recorrendo a uma argumentação mais profunda no preâmbulo

Advertem que essa constatação não apresenta propriamente uma justificativa normativa para a existência da revisão judicial. Limitam-se a descrever um fato que,

\footnotetext{
${ }^{410}$ Ibid, p. 101-104.

${ }^{411}$ Ibid, p. 105. Ou então na seguinte passagem: "The Charter can act as a catalyst for a two-way exchange between the judiciary and legislature on the topic of human rights and freedoms, but it rarely raises an absolute barrier to the wishes of the democratic institutions". (Ibid., p. 81)

${ }^{412}$ Ibid, p. 79.

${ }^{413}$ Numa primeira resposta aos críticos, Hogg e Bushell assim afirmaram: "In the end, if the democratic will is there, a legislative way will be found to achieve the objective, albeit with some new safeguards to protect individual rights" ("The Charter Dialogue Between Courts and Legislatures", p. 22).
} 
possivelmente, torna a objeção contra a legitimidade democrática da revisão judicial menos plausível, ou menos convincente. Mostram que o modelo de revisão judicial canadense é menos ofensivo do que os críticos supõem.

$\mathrm{O}$ artigo teve enorme repercussão na literatura constitucional canadense, com autores que o apoiaram e desenvolveram a idéia, e outros que a criticaram. Repercutiu também na própria corte, com juízes que compraram a imagem e passaram a se enxergar como "interlocutores" no diálogo. O autor que veio a dar fundamentação teórica de maior fôlego a essa idéia foi Kent Roach. Segundo ele, a democracia tornase mais auto-consciente, auto-crítica e real quando os extremos da supremacia judicial ou legislativa são evitados. Cortes e parlamentos atuam em conjunto e dão respostas às respectivas miopias. ${ }^{414}$ Uma vez que se percebe que a corte não tem a última palavra, a principal preocupação não deve ser com limitar o poder judicial, e sim com a forma pela qual ele pode otimizar e reforçar a democracia. ${ }^{415}$ Lembra que teorias do diálogo não fornecem respostas certas para os casos difíceis de interpretação, mas despertam um processo no qual todos participam na busca dessa resposta. Recusa o monólogo da supremacia legislativa ou judicial. ${ }^{416}$ A corte não impede que o parlamento prevaleça, se este quiser, mas o induz a assumir a responsabilidade política e a apresentar justificativas aceitáveis para qualquer restrição a direito. Consegue-se, por meio dessa estratégia, aumentar o desempenho de ambas as instituições. ${ }^{417} \mathrm{O}$ maior perigo para a democracia, segundo Roach, não seria o ativismo judicial, mas a deferência legislativa. Ativismo judicial se responde, nesse sentido, com ativismo legislativo. ${ }^{418}$

\footnotetext{
${ }^{414}$ The Supreme Court on Trial: Judicial Activism or Democratic Dialogue, p. x.

${ }^{415}$ Ibid, p. 236.

${ }^{416}$ Ibid, p. 251.

417 "A constructive and democratic dialogue between courts and legislatures under a modern bill of rights such as the Charter can improve the performance of both institutions. (...) The democratic dialogue (...) can avoid the monologues and unchecked power that may be produced by either unfettered legislative supremacy or unfettered judicial supremacy". Ibid, p. 295.

418 "The answer to unacceptable judicial activism under a modern bill of rights is legislative activism and the assertion of democratic responsibility for limiting or overriding the Court's decisions. Citizens can enjoy the benefits of judicial activism without the costs of judicial supremacy. (...) Modern bills of rights and their robust judicial enforcement allow governments to be put on trial... But the Court is also on trial... In the end, all of us are on trial for how we exercise the powers of self-government. That is the burden and the privilege of democracy". (Ibid, p. 296)
} 
Essa tese não foi recebida sem resistência. Manfredi e Kelly foram os primeiros a atacar frontalmente as conclusões de Hogg e Bushell. ${ }^{419}$ Argumentaram que a pesquisa empírica possuía falhas metodológicas e que o fenômeno era quantitativamente menos extenso e qualitativamente mais complexo do que propugnado. Essencialmente, disseram que "diálogo genuíno" só ocorre quando o parlamento desafia a posição da corte (insistindo na mesma lei, por exemplo) e não quando simplesmente a obedece. Num diálogo genuíno, não há hierarquia na relação. Sempre que o legislador se subordina à decisão judicial, haveria a distorção da política pública e debilitação da democracia. ${ }^{420}$

Rainer Knopff também não aceita a caracterização desse fenômeno como diálogo. ${ }^{421}$ Segundo ele, cortes intensificam em vez de moderar o extremismo e a polarização de um conflito de direitos. A decisão judicial, sob aparente neutralidade, faz um dos lados do extremo ganhar e o outro sentir-se derrotado. A idéia da corte como anteparo à tirania da maioria seria um mito. Mais freqüentemente, o processo legislativo tem a aptidão para encontrar um meio-termo que acomode os conflitos. A moderação e o compromisso, virtudes de uma política democrática, passam ao largo das cortes, e a noção de diálogo não resolveria esse problema. ${ }^{422}$

Morton argumenta que, ao contrário da retórica que opõe maioria e minoria, na grande parte das disputas sobre direitos na democracia há um conflito entre duas minorias ativas e uma grande massa majoritária instável e desorganizada. O que a decisão judicial faz, nesse sentido, é inverter o status quo: em vez da prevalência da posição da minoria que se mobilizou e conseguiu, oportunamente, uma coalizão majoritária no processo legislativo, passa a valer a preferência da minoria derrotada. Se por um lado é verdade que a decisão judicial não constitui barreira absoluta, em alguns assuntos delicados que ameaçam fraturar a unidade partidária, o custo político de enfrentar a minoria que perdeu no parlamento e venceu na corte pode ser muito

\footnotetext{
${ }^{419}$ Cf. Manfredi e Kelly, "Six Degrees of Dialogue: A Response to Hogg and Bushell".

${ }^{420}$ Esse é também um argumento conhecido de Mark Tushnet em "Policy Distortion and Democratic Debilitation: Comparative Illumination of the Counter-Majoritarian Difficulty". Como vimos no capítulo 3, nesse texto Tushnet recomenda a recuperação das preocupações de Thayer e Bickel, para quem uma revisão judicial "mais do que mínima" causa debilitação democrática e distorção da política pública.

421 "Courts don't make good compromises".

422 "As a system of checks and balances, a 'dialogue' of the unaccountable holds little attraction, especially if, as I think, it will not often achieve the central purpose of any good system of checks and balances: political moderation and compromise". (Ibid, p. 34)
} 
alto. Isso impacta a política pública. ${ }^{423}$ Por isso, o que Hogg e Bushell nomearam como diálogo, seria mais freqüentemente um monólogo, em que juízes falam e legisladores escutam. ${ }^{424}$

Para Andrew Petter, teorias do diálogo teriam três defeitos: exageram a capacidade de o legislador responder; subestimam a posição privilegiada das cortes, que se expressam na retórica dos direitos, em face do legislador, que mais freqüentemente o faz na linguagem dos limites; ignoram a forma pobre pela qual os direitos têm impregnado o debate público, independentemente de qualquer diálogo. ${ }^{425}$ Um caminho mais adequado para a teoria democrática seria perseguir 0 aperfeiçoamento institucional do parlamento, e não celebrar uma instituição não eleita que supostamente ameniza os problemas da outra. ${ }^{426}$

Por fim, Janet Hiebert é, no debate canadense, a que oferece uma versão mais densa e normativamente trabalhada da corrente da "construção coordenada". Tem sérias reservas à noção de Hogg e Bushell porque, segundo ela, eles atribuem à corte um papel corretivo incompatível com o seu ideal de "responsabilidades compartilhadas" e de "governo por meio do debate". Para ela, a interação não pode ser regida pela corte. Ambas as instituições possuem expertises singulares que precisam ser reconhecidas. Nessa comparação de capacidades institucionais, mostra

\footnotetext{
423 "The observation is right, but the conclusion they draw from it wrong. Nullification does not have to raise an absolute barrier. Depending on the circumstances, a small barrier may suffice to permanently alter the public policy". ("Dialogue or Monologue")

${ }^{424} \mathrm{O}$ incômodo com a palavra "diálogo", que supostamente estaria encobrindo a subordinação do legislador e a hierarquia dessa relação, é manifestado também por alguns outros autores. Grant Huscroft é outro crítico de destaque, que considera tal teoria uma conveniente racionalização do ativismo judicial: "I am all in favor of a dialogue between the Supreme Court and the other branches of government in Canada about the meaning of the Charter, in which the Court would respect and be influenced by the legislature's interpretation of the Charter. But this is not the sort of dialogue that dialogue theorists have in mind. (...) The 'dialogue' they have in mind is one in which the Court is free to interpret the Charter as it will, with the legislature required to adopt the Court's interpretation and act within such parameters as the Court allows. This is not a dialogue. It is top-down constitutionalism, and it is a poor way in which to run a constitutional democracy". ("Rationalizing Judicial Power: The Mischief of Dialogue Theory", em The Charter at 25).

425 "Twenty Years of Charter Justification: From Liberal Legalism to Dubious Dialogue", p. 196.

426 "I am not suggesting that there is not cause for despair about the current state of Canadian democracy. On the contrary, it seems to me that our parliamentary structures are horribly unrepresentative of, and accountable to, the citizens they are supposed to serve. But subjecting one democratic institution to review by another does not make either less so. And celebrating the interaction of the two as a 'democratic dialogue' trivializes democracy (...) Rather than directing our energies to what Laurence Tribe has called 'the futile search for legitimacy', or looking for democracy where it does not reside, we would do better to try resuscitating it where it does, by seeking ways to reform and revitalize the faltering institutions of the democratic state". (Ibid, p. 198).
} 
que cortes e parlamentos analisam problemas sob prismas diferenciados. Juízes não estariam bem posicionados para avaliar quais os melhores ou piores meios escolhidos pelo legislador para perseguir seus objetivos. ${ }^{427}$ Seriam capazes, todavia, de fiscalizar se a deliberação legislativa foi de boa qualidade e se houve um esforço sincero de balancear os direitos e seus limites.

A ambiciosa missão política da Carta de Direitos, segundo Hiebert, foi impregnar a prática justificadora dos três poderes, e não de simplesmente atribuir à corte a tarefa de policiar os outros, supostos violadores em potencial. Essa atitude reduziria a responsabilidade dos outros poderes, e traria o risco de que eles, receosos do controle externo, usem de meios acanhados para implementar seus objetivos. ${ }^{428}$ Rechaça, veementemente, a hegemonia judicial como condição da proteção de direitos, e propõe que as responsabilidades sejam estabelecidas em termos relacionais e horizontais. Supõe que corte e parlamento devam ter um grau de modéstia sobre a superioridade dos seus julgamentos e respeito em relação à opinião diversa do outro. $^{429}$

Para Hiebert, não se pode cair na armadilha cínica (por recusar qualquer valor moral a interpretações do parlamento) e estreita (por restringir o significado da constituição ao que a corte estabelece) quando se pensa no papel dos poderes sob a égide da Carta $^{430}$ Um regime não precisa fazer uma opção excludente por uma instituição em lugar da outra. ${ }^{431} \mathrm{O}$ legislador não pode ter aversão ao risco de uma revisão judicial, pois deve enxergar a si mesmo como parceiro dotado de igual legitimidade para interpretar as normas constitucionais. Em grande medida, o parlamento terá a corte que merece: se praticar uma deliberação sincera e cuidadosa, a probabilidade de sofrer invalidação será menor. ${ }^{432}$ Caso isso ocorra, não deve inibir-se

\footnotetext{
${ }^{427}$ Limiting Rights: The Dilemma of Judicial Review, p. 121-125.

${ }^{428}$ Charter Conflicts: What is Parliament's Role?, p. 18-19.

429 "A relational approach conveys separate yet interconnected approached taken to render judgment. Unlike many explanations of constitutional dialogue, it contemplates the Charter's significance more in terms of requiring careful scrutiny by each institution of governance than in terms of the judiciary policing or correcting the "wrong' decisions of the legislature". (Ibid, p. 51)

${ }^{430}$ Ibid, p. 54.

431 “'Are judges or elected representatives more likely to have better answers to rights conflicts?' My answer is: Why must a polity choose one set of institutional actors and excuse or exclude the others? Better answers are likely to emerge when they are the products of carefully reasoned judgments about whether state actions are justified in light of a polity's fundamental normative values". (Ibid, p. 72)

${ }^{432}$ "The extent to which Parliament will be able to convince the judiciary about the merits of how it believes Charter conflicts should be resolved may be a direct reflection of the extent of its commitment
} 
em demonstrar que suas justificativas são consistentes e produto de deliberação transparente.

Hogg e Bushell responderam a parte dessas críticas. Primeiro, num artigo curto dirigido a Manfredi e Kelly. ${ }^{433}$ Quanto à distorção da intenção legislativa, sustentaram que não é qualquer interferência judicial que abalará os objetivos da política pública. Uma generalização desse tipo não percebe que o legislador tem meios diversos para perseguir os mesmos fins, e eventualmente pode aceitar um alternativo em face da argumentação judicial, sem prejudicar substancialmente a política pública. ${ }^{434}$ Quanto à falta de diálogo genuíno, simplesmente afirmaram que sua intenção com o uso dessa metáfora teria sido mais modesta. Limitam-se a verificar a possibilidade de o legislador, se quiser, responder à corte. Nesse sentido, se a decisão judicial culminou num "extremismo", nada impede que o parlamento a enfrente, mesmo que, muitas vezes, prefira não fazê-lo. O fato de não o fazerem, ademais, pode bem indicar que a vontade democrática não é assim tão sólida. Portanto, não haveria por que acusar a decisão judicial de ir contra ela.

A resposta mais extensa e elaborada veio somente em 2007, numa edição comemorativa da mesma revista para marcar os dez anos do artigo original. Essa edição foi aberta por um novo artigo dos autores, alguns novos comentários dos críticos, e, por fim, uma síntese conclusiva de Hogg e Bushell. Ali, tiveram a oportunidade de enfrentar a vasta fortuna crítica e de reafirmar, com pesquisa empírica atualizada, o argumento inicial e a sobrevivência das "seqüências legislativas". Dizem que as críticas fizeram barulho exagerado por causa da metáfora sugerida. Salientam que estão mais preocupados com a demonstração de um fato e suas conseqüências para a legitimidade da corte. Não entrariam em disputa se um novo termo, desde que mais adequado, fosse sugerido para referir-se a tal fato. ${ }^{435}$ to careful and principled judgment. To a considerable degree, Parliament is likely to get the kinds of judicial rulings it deserves". (Ibid, p. 227)

433 "Reply to Six Degrees of Dialogue".

434 "Our point is that judicially-imposed constitutional norms rarely defeat a desired legislative policy; they generally operate at the margins of legislative policy, affecting issues of process, enforcement, and standards, all of which can accommodate most legislative objectives". (Ibid, p. 534)

435 "Charter Dialogue Revisited - or "Much Ado About Metaphors", p. 26: "We never made the ridiculous suggestion that courts and legislatures were actually talking to each other. (...) We would cheerfully adopt another word if we were persuaded that another word is better, but no one has so far suggested a better word". Ou, na conclusão do artigo, p. 54: "although we do not carry a torch for the word 'dialogue' as the only possible description for the phenomenon of legislative responses to judicial decisions under Charter, we say that our critics should deal with the significance of the phenomenon, 
Mostram que o fenômeno do diálogo, tal como o definiram no artigo, e independentemente de qual seja a melhor palavra para designá-lo, está vivo e se disseminou na prática constitucional canadense.

A noção foi incorporada à auto-percepção da corte, não sem divergências internas sobre suas implicações. Nesses dez anos, a prática do diálogo se refinou, especialmente porque alguns casos de "réplica" do legislador ("second-look cases"), ou seja, casos em que o legislador insiste numa lei anteriormente declarada inconstitucional, começaram a chegar à mesa da corte. Esses casos são interessantes para testar o eventual papel normativo da noção de diálogo. O argumento original disse que a corte não tem a última palavra porque o parlamento pode responder. $\mathrm{O}$ parlamento respondeu e o problema voltou para a corte. O fato de ser uma "réplica", e não uma lei promulgada pela primeira vez, tem alguma importância para a avaliação de constitucionalidade?

A corte se dividiu sobre eventual grau de deferência que esses casos mereceriam. Alguns juízes chegaram a usar a noção de diálogo para justificar a deferência. Outros resistiram e disseram que diálogo não poderia ser transformado em abdicação. A juíza McLachlin resumiu sua posição em frase irônica: "A saudável e importante promoção do diálogo entre cortes e parlamentos não deveria ser rebaixada a uma regra que diz: 'se você não foi bem sucedido da primeira vez, tente, tente de novo". ${ }^{436}$

Os próprios autores rejeitam o uso da metáfora para justificar a deferência, e posicionam-se de modo contrário à teoria da "construção coordenada". ${ }^{437}$ Acreditam que a constituição canadense, sob pena de anarquia interpretativa, não permite que o parlamento compartilhe de autoridade para fazer prevalecer a sua opinião a respeito da constituição. Defendem uma posição que pode parecer curiosa: o judiciário tem sim o monopólio sobre a interpretação final da constituição (que pode ser certa ou

\footnotetext{
rather than making 'much ado about metaphors"'.

${ }^{436}$ Ibid, p. 22-23.

${ }^{437}$ A Hiebert responderam diretamente, mostrando uma discordância de grau: "We do not take the idea as far as Hiebert, as we believe that the ultimate 'reasonable limits' determination must be made by the courts. Yet, we agree that some degree of deference should be accorded to legislatures on section 1 matters". (Ibid, p. 49)
} 
errada), mas suas decisões dificilmente impedirão a resposta legislativa. ${ }^{438}$ A principal exceção à autoridade interpretativa final da corte seria o recurso à Seção 33. Além disso, em virtude de fatos novos, o parlamento poderia apresentar à corte justificativas diferentes, o que teria o efeito saudável de provocar a corte revisitar decisões passadas. $^{439}$

Dito de outro modo, do ponto de vista jurídico-normativo, o significado da constituição é determinado, em último grau, pela corte. No entanto, empiricamente, verifica-se que o parlamento encontra espaço para responder e perseguir seus objetivos. Isso traria um sério desafio à objeção majoritária contra a revisão judicial. ${ }^{440}$ Os autores são cautelosos, entretanto, para derivar daí uma justificativa normativa para existência desse arranjo. Não concordam com o uso que desse fato fazem alguns juízes para justificar uma postura ativista ou deferente da corte, mas destacam que não se pode negligenciar a possibilidade de que a corte seja persuadida pelo parlamento nesse processo, ou vice-versa. Claramente, os autores tangenciam, ainda que não de maneira confortável, a preferência normativa pela revisão judicial. Em diversas passagens, demonstram que esse arranjo não é apenas um dado inofensivo, mas uma instituição que acrescenta valor. Defendem a virtude de um mecanismo que mitiga a inércia do parlamento e o força a posicionar-se sobre questões políticas controversas ou, usando palavras de Roach, que fabrica desacordos e converte monólogos majoritários complacentes em diálogos intensos. ${ }^{441}$

\footnotetext{
${ }^{438}$ Ibid, p. 33.

${ }^{439}$ Um ponto de vista criativo e instigante, que defende uma "hipótese moderada" de construção coordenada, foi oferecido por Dennis Baker e Rainer Knopff em "Minority Retort: A Parliamentary Power to Resolve Judicial Disagreement in Close Cases". Eles tentam dar fundamentação teórica à atitude do parlamento num caso em que, em vez de seguir a decisão final da corte em controle de constitucionalidade, optou por obedecer a posição dos votos vencidos. Num caso em que a decisão da corte se dá por maioria mínima de 5 a 4 (os chamados "close cases"), eles defendem a legitimidade de o parlamento seguir a variante interpretativa da parte vencida, presumivelmente também razoável e fundada em argumento de princípio. A "minority retort", conforme definem, é um desdobramento enriquecedor do diálogo e dá peso também aos votos vencidos: "Simply put, the Court chooses the menu and the legislature makes the order. By managing the available alternatives, the Court still constraints the ability of the legislature to influence constitutional interpretation" (p. 355). Os autores percebem as sutis diferenças simbólicas (e as implicações políticas) do julgamento unânime e do julgamento por maioria mínima (close cases) para fins do diálogo e do desafio legislativo. Poderíamos ir além e especular sobre a maior resistência que uma decisão unânime eventualmente tem contra o desafio legislativo, ou sobre as diferenças entre uma opinião genuinamente deliberativa e institucional e a opinião agregativa (seriatim). Neste caso, o legislador interessado em desafiar a corte teria que persuadir juízes individuais. Naquele, teria que convencer a instituição.

440 "Charter Dialogue Revisited - or "Much Ado About Metaphors", p. 44: "since the last word can nearly always be (and usually is) that of the legislature, the anti-majoritarian objection is not particularly strong".
} 
Em síntese, para Hogg e Bushell, a chave para a existência do diálogo é a possibilidade da seqüência legislativa. Não estão preocupados com os efeitos da interação no comportamento dos agentes e nem abordam as negociações informais entre os poderes que eventualmente se antecipam à posição do outro. Sua pretensão teórica foi verificar com mais vagar se a preocupação com o elemento anti-majoritário do regime merecia tanto alarde. Perceberam que, se o legislador é capaz de responder, e de fato o tem feito com freqüência, o problema, caso exista, é muito menor do que se supunha. O processo que descrevem é guiado pela corte. O legislador é reativo. São entusiastas do diálogo, mas sem abandonar a noção de "última palavra", que continuaria, constitucionalmente, com a corte, e, na prática, com o legislador.

\section{Novos experimentos no constitucionalismo do commonwealth}

Sucedendo a experiência canadense, outros países do chamado constitucionalismo do commonwealth também ingressaram no projeto de reformas institucionais com vistas ao duplo objetivo de proteger direitos e escapar da "dificuldade contra-majoritária", concedendo a última palavra ao legislador. Juntamente com o Canadá, o Reino Unido e a Nova Zelândia compõem hoje uma das experimentações mais interessantes do direito constitucional comparado. A literatura constitucional desses dois países tem sido influenciada pelo fértil debate canadense a respeito do diálogo.

Stephen Gardbaum compara minuciosamente as características dessas três reformas. ${ }^{442}$ A expansão do constitucionalismo nas ondas do pós-Segunda Guerra e do pós-Queda do Muro de Berlim teria reproduzido, basicamente, os três elementos essenciais do modelo americano: direitos com status jurídico superior em relação à legislação; o entrincheiramento dos direitos contra reforma legislativa; a proteção pela revisão judicial. A distinção entre controle difuso e controle concentrado seria já um desdobramento dessa espinha dorsal americana. Disseminou-se uma mentalidade rígida com dois pólos excludentes, sem meio-termo: ou a supremacia legislativa, ou a proteção de direitos por meio da revisão judicial nos moldes americanos.

\footnotetext{
${ }^{441}$ Ibid, p. 45: "Surely democracy is served, not hampered, by forcing the discussion of controversial issues that otherwise might be neglected".

442 "The New Commonwealth Model of Constitutionalism".
} 
Nesses países do commonwealth, elementos essenciais do modelo americano estão ausentes. Abriram uma alternativa intrigante que rejeita o axioma segundo o qual a supremacia legislativa é incompatível com proteção de direitos. Criaram, em oposição do modelo forte americano (strong judicial review), formas fracas de revisão judicial (weak), uma terceira via comparável somente com o modelo francês.

A Declaração de Direitos da Nova Zelândia (New Zealand Bill of Rights Act), de 1990, é uma espécie sui generis de lei. Tem força jurídica menor do que uma lei ordinária, pois não revoga uma lei anterior que conflite com ela. Seu método de efetivação dos direitos é engenhoso. Impõe-se à corte o dever de interpretar as leis de maneira consistente com os direitos e ao legislador de pagar os custos políticos de uma violação. ${ }^{443}$ Uma lei inconsistente com a Declaração não pode ser invalidada judicialmente, mas a corte controla o seu significado. É instrumento juridicamente semelhante à declaração legislativa de direitos canadense, de 1960, mas foi recebida por uma cultura judicial diversa: na Nova Zelândia, ao contrário de como ocorreu no Canadá, juízes têm sido entusiastas na proteção de direitos, um bom exemplo de que soluções institucionais semelhantes surtem efeitos diferentes em cada cultura em que decantam. O arranjo criado deixa a última palavra com o parlamento, mas pretende induzi-lo a levar direitos a sério e a estar plenamente informado sobre as questões de direitos por trás de sua decisão. ${ }^{444}$

A Declaração de Direitos do Reino Unido (UK Human Rights Act), de 1998, representa uma revolução no sistema constitucional britânico. Ela possibilitou aos britânicos questionar, nas próprias cortes britânicas, a validade de um ato de autoridade à luz dos direitos previstos na Convenção Européia de Direitos Humanos. A simples existência de um catálogo de direitos já é uma mudança radical naquela tradição, mas o desenho também foi original: a corte tem o dever de interpretar as leis à luz dos direitos (o que impacta a tradição hermenêutica britânica, mais formalista), e o poder de proferir uma "declaração de incompatibilidade". O parlamento,

\footnotetext{
${ }^{443}$ Ibid, p. 29.

444 "Although the former do not deny a legislature the power to act inconsistently with fundamental rights, they seek to force the legislature into self-conscious, publicized, informed, and principled debates regarding rights, requiring clear statements of legislative decision to violate them. The general idea is that it is appropriate for the legislature to have the final word on what is the law of the land but only where there are mechanisms designed to ensure that in its decisionmaking procedures, rights are taken seriously". (Ibid, p. 33)
} 
juridicamente, não tem dever de responder a essa declaração. Suas leis, contudo, não estão mais imunizadas contra a invalidade, pois não têm poder de revogação da Convenção Européia. O único efeito formal da "declaração de incompatibilidade" é dar ao ministro o poder de requerer um procedimento acelerado na emenda da lei “incompatível”. Estabelece-se, sobretudo, uma expectativa política de que a norma “incompatível” será suprimida e que a cultura jurídica esteja mais atenta aos direitos, até então ausentes do debate legislativo. ${ }^{445}$

Essas três inovações ampliaram o cardápio institucional do direito constitucional comparado. Encontraram soluções intermediárias entre supremacia judicial e supremacia legislativa, e confiaram em testes institucionais originais numa área que não teve grande inventividade nos últimos 50 anos. Tentaram responder ao problema da eventual debilitação democrática por meio da retirada da palavra final da corte e da atribuição de um ônus adicional de justificação à decisão legislativa. Buscaram transformar o discurso sobre direitos - em vez de monólogo judicial, estimulam um diálogo inter-institucional balanceado. Por fim, almejaram reforçar a legitimidade da corte por meio de uma divisão de trabalho que atenua a percepção de que a corte está engajada, sozinha, em pura atividade discricionária ou legislativa.

Estes são os exemplos recentes de reformas institucionais que apostam não numa revisão judicial salvacionista, que aplica um corretivo externo ao poder legislativo. São baseadas na esperança de que, por meio de alguns incentivos institucionais, o parlamento pode levar direitos a sério. A decisão judicial não precisa receber, necessariamente, poder formal para que seja capaz de influenciar o comportamento do legislador, em nome da proteção de direitos. Conceberam-na de forma diferente: um mecanismo que conserva a linguagem dos direitos no interior do debate político, e que conta com sua força persuasiva para ser obedecido. São opções por vias mais políticas do que jurídicas (no sentido de direito como comando vinculante ou sanção) para proteger direitos. Revela maior confiança na política e nas demandas deliberativas que ela pode insuflar, em mecanismos mais sutis que fogem

\footnotetext{
${ }_{445}$ "Human Rights Act thus promises to force discourse about rights into the forefront of a legal culture from which they were previously largely absent". (Ibid, p. 35)
} 
da armadilha de Marshall e Kelsen, ${ }^{446}$ segundo a qual ou há força, poder real, "porrete", ou não há proteção de direitos.

Não há ainda tempo suficiente para avaliar se essas apostas foram bem sucedidas. Pretender limitar o poder do legislador por mecanismos de persuasão, de distribuição de custos políticos e ônus de justificação parece certamente um projeto ingênuo e fadado ao fracasso (ou à manipulação retórica e demagógica). Previsivelmente, desperta o ceticismo daqueles treinados pela ciência política hegemônica. Nos EUA, o desenho constitucional está congelado desde sua fundação e as variações encontram-se nas práticas interpretativas. O fenômeno do diálogo, ali, foi uma descoberta dentro do modelo existente. Nesses três países do commonwealth, ao contrário, buscou-se instalar o diálogo por meio de reformas institucionais que amenizaram a matriz forte da revisão judicial.

\section{Quem e como e quando e por que decide sobre direitos na democracia?}

A imagem do diálogo, como se pôde perceber dessa longa descrição, foi frutífera para atacar a idéia de "última palavra" (especialmente a judicial). Uma decisão de controle de constitucionalidade, portanto, não impede que uma comunidade democrática continue a se mover e reforme decisões que não a agradem. Certamente não é a única imagem disponível para inspirar a imaginação política a respeito. As alternativas mais presentes - última palavra, guardião etc. - trazem, porém, o risco de atrofiar a extensão da análise. Diálogo nos torna sensíveis ao fato de que na política, decisões são provisórias, por mais custoso e demorado que seja revertê-las. Traz para a discussão a dimensão temporal da política e de continuidade histórica da comunidade. No entanto, ela não pode justificar qualquer coisa, ou qualquer tipo de revisão judicial. É necessário pensar em condições para o seu exercício, em modelos de diálogo que são melhores e mais democráticos do que outros. Nos próximos capítulos, defenderei alguns parâmetros normativos, e mostrarei alguns dos limites da perspectiva da "última palavra", apesar de não podermos abandoná-la completamente.

\footnotetext{
${ }^{446}$ Refiro-me ao argumento clássico que justifica o controle de constitucionalidade como decorrência da supremacia da constituição. As matrizes de Marshall e de Kelsen estão bem analisadas em Carlos Santiago Nino (The Constitution of Deliberative Democracy, p. 189)
} 
Para fins de uma síntese simplificadora dos três capítulos descritivos da tese, a tabela abaixo se utiliza da pergunta estrutural de desenho institucional, explicada no capítulo 1, para comparar as três posições abrangentes. A tabela não dá conta de todos os argumentos que apresentei nos últimos capítulos. Especialmente na dimensão do "por que", haveria muito mais a ser dito. Há, como vimos, outras vias de justificação do diálogo (entre as teorias que procuram "justificá-lo", além de descrevê-lo). A aposta no seu valor epistêmico é o que inspira essa tese, e se destaca nessa tabela.

\begin{tabular}{|l|l|l|l|}
\hline Posicionamentos & \multicolumn{1}{|c|}{$\begin{array}{c}\text { 1. Inclinação por } \\
\text { juízes e cortes }\end{array}$} & $\begin{array}{c}\text { 2. Inclinação por } \\
\text { legisladores e parlamentos }\end{array}$ & $\begin{array}{c}\text { 3. Inclinação por } \\
\text { ambos: diálogo inter- } \\
\text { institucional }\end{array}$ \\
\hline Quemensões & Corte & Parlamento & Ambos \\
\hline Como? & $\begin{array}{l}\text { Inputs e outputs formais da } \\
\text { decisão judicial }\end{array}$ & $\begin{array}{l}\text { Inputs e outputs formais da da } \\
\text { decisão legislativa }\end{array}$ & Combinação de ambos \\
\hline Quando? & Por último & Por último & Alternadamente no tempo \\
\hline Por quê? & $\begin{array}{l}\text { Juízes estão melhor } \\
\text { situados para decidir sobre } \\
\text { direitos }\end{array}$ & $\begin{array}{l}\text { Legisladores estão melhor } \\
\text { situados para decidir sobre } \\
\text { direitos }\end{array}$ & $\begin{array}{l}\text { A eleva a interação deliberativa } \\
\text { capacidade } \\
\text { epistêmica da democracia }\end{array}$ \\
\hline
\end{tabular}

\section{O empírico e o normativo nas teorias do diálogo}

A interação é um fato, não uma escolha ou uma possibilidade. Não decorre da manifestação de vontade de um poder ou de algum dispositivo institucional específico, mas é conseqüência necessária da separação de poderes. Mais, há um "diálogo silencioso" entre as instituições, conduzido de forma consciente ou não, que cabe ao teórico perceber e reconstruir.

$\mathrm{Na}$ classificação apresentada nesse capítulo, e em cada uma das correntes descritas, pode-se perceber uma tensão entre o empírico e o normativo. Tentei explicitar como cada autor vê as implicações normativas de suas proposições 
positivas. $\mathrm{Na}$ primeira parte do capítulo, o aspecto prescritivo é mais evidente. Dirigem recomendações aos juízes sobre como decidir, considerando o potencial dialógico da corte. $\mathrm{Na}$ segunda parte, enxerga-se o diálogo no simples aspecto temporal da interação institucional. Alguns vão além disso, e mostram que essa interação é qualificada pela cultura da deliberação que ela estimularia. Têm em comum a pretensão de promover um "choque de realidade" nas teorias normativas tradicionais, um ataque empírico às especulações que abstraem as instituições reais. A corte está imersa na política, e sua atuação está condicionada por diversos fatores que não permitem a livre leitura da constituição. Democracias contemporâneas seriam mais complicadas do que as categorias clássicas do debate conseguem captar.

São herdeiros de um velho desafio de Dahl: a corte não consegue ser contramajoritária por muito tempo, a não ser que as maiorias sejam meramente de ocasião. $^{447} \mathrm{O}$ máximo que a corte pode conseguir é atrasar o processo. Essa constatação dá aos críticos da revisão judicial um ônus mais difícil de demonstrar, ao menos, uma entre duas hipóteses: a falsidade dessa proposição empírica ou o porquê a revisão judicial seria ilegítima e indesejável mesmo durante esse curto espaço de tempo em que a corte consegue segurar uma maioria. De outro lado, dá aos defensores da revisão judicial o ônus de comprovar por que essa proteção anti-majoritária de duração limitada ainda assim, no final das contas, se justifica na democracia. Nenhuma das teorias da última palavra consegue dar uma resposta convincente ao desafio. Teorias do diálogo são certamente mais promissoras.

Há certa complementaridade entre as duas partes do capítulo. Uma teoria do diálogo precisa combinar a abordagem da separação dos poderes com alguma teoria sobre a decisão, tanto para cortes quanto para parlamentos. Diálogo nasce da conjugação de um desenho institucional e de uma cultura política. O desenho institucional cria incentivos para tipos diferentes de interação. Tais incentivos não determinam, contudo, o comportamento institucional isoladamente.

Nos capítulos 6 e 7, pretendo caminhar na direção de uma teoria normativa do diálogo inter-institucional que aprofunde o problema posto até aqui e afirme mais

\footnotetext{
447 "It is to be expected, then, that the Court is least likely to be successful in blocking a determined and persistent lawmaking majority on a major policy and most likely to succeed against a weak majority". ("Decision-making in a Democracy: The Supreme Court as a National Policy-Maker", p. 284)
} 
claramente o seu potencial epistêmico. Empresto muitas peças das teorias resenhadas nesse capítulo. Idéias de prudência e faro político, em Bickel, de análise contextual do minimalismo ou maximalismo, em Sunstein, das novas rodadas, em Fisher, de variações no quanto cada poder deve deferir em cada momento, em Whittington, das capacidades primárias e secundárias, em Pickerill, da tensão dinâmica e da subversão do status quo provocadas pela corte, em Friedman, possuem certa unidade. O debate canadense é ainda mais apegado a uma noção formal de última palavra e à preservação da última palavra legislativa. No entanto, a idéia de que ativismo judicial se responde com ativismo legislativo, em Roach, e de que a corte pode combater a inércia e forçar o parlamento a assumir responsabilidade e a justificar mais claramente suas decisões, em Hogg e Bushell, parecem-me conciliáveis também. Não se trata de ecletismo contemporizador, mas da tentativa de identificar alguns acordos de fundo. Essas teorias carecem, porém, de um desenvolvimento mais ambicioso sobre o papel da deliberação na política, o desdobramento que tentarei fazer aqui. 


\section{Capítulo 5}

\section{Auto-governo e direito ao erro}

A democracia pressupõe que indivíduos são igualmente competentes para governarem a si próprios. Não só cada indivíduo é senhor de si mesmo, mas a comunidade integrada por eles é também autônoma. Transpor o ideal do auto-governo individual para o coletivo exige uma mediação institucional, principal desafio desse regime. ${ }^{448} \mathrm{O}$ que se deve evitar, portanto, é o paternalismo político - a supressão da autonomia e a presunção de que há indivíduos menos competentes que outros para participarem das decisões coletivas. Alguns autores acreditam que a revisão judicial traz esse risco. Três costumam ser as referências imediatas a respeito.

James Bradley Thayer afirmou que o custo da exclusividade judicial é que "o povo, dessa maneira, perde a experiência política, a educação moral e o estímulo que decorre da luta política pela via ordinária, e da oportunidade de corrigir os próprios erros". ${ }^{449} \mathrm{O}$ recurso fácil à revisão judicial acabaria por diminuir a capacidade e responsabilidade políticas do povo. A correção dos erros legislativos por meio da revisão judicial seria um mecanismo exógeno pernicioso, que não incentiva o aprendizado decorrente da oportunidade de auto-corrigir-se. Thayer, seguindo essas convicções, fornece a famosa fórmula minimalista do "erro claro" (clear mistake). Para ele, uma revisão judicial mais do que mínima causaria debilitação democrática.

Learned Hand segue a mesma inquietação. $\mathrm{O}$ ato de escolher representantes, para ele, estimula um senso de "empreendimento comum" (common venture) que a revisão judicial faz desaparecer. Este controle não traria nenhum efeito benéfico a um regime político. Seu raciocínio é direto: se há, na comunidade, uma cultura da liberdade, nenhuma corte precisa salvá-la; se não há, nenhuma corte pode salvar. A garantia da liberdade não estaria nas instituições, mas "no coração de homens e mulheres". 450

\footnotetext{
${ }^{448}$ Para Frank Michelman, olhar as decisões políticas sob o ponto de vista do auto-governo individual é o que se pode chamar de "dificuldade institucional" (Brennan and Democracy, p. 15).

${ }^{449}$ John Marshall, p. 106-107, citado por Paul Brest em "Who Decides?", p. 671. Paul Brest, nesse mesmo artigo, também esclarece o problema da "exclusividade judicial" (Ibid, p. 670): "The belief in judicial exclusivity is so widespread that it is usually assumed rather than argued for. (...) Indeed, it is not uncommon for legislators to believe that constitutional questions are none of their business at all". 450 "It would be irksome to be ruled by a bevy of Platonic Guardians (...). Of course I know how illusory would be the belief that my vote determined anything; but nevertheless when I go to the polls I
} 
Robert Dahl, por fim, considera que o ativismo judicial seria uma espécie de "regime de guardiões" (guardianship), por meio do qual indivíduos, incapazes de se auto-governarem, delegam essa responsabilidade para pessoas melhor dotadas para tanto. ${ }^{451}$ Dahl aceita a revisão judicial somente dentro dos limites em que ela favoreça a competição democrática. Chama essa alternativa de quasi guardianship. ${ }^{452}$

Auto-governo, segundo esse autores, envolve a oportunidade de errar, de aprender com o erro e de corrigi-lo sem a interferência de um agente externo. Não pode ser, contudo, o único valor que orienta a construção de procedimentos decisórios. O desenho de instituições precisa carregar alguma pretensão epistêmica, ou seja, a aposta de que um modo de decidir (input) gerará, ou pelo menos terá maior probabilidade de gerar, os melhores resultados (output). Dito de outro modo, o procedimento não pode se limitar a promover o auto-governo, mas deve também ser capaz de gerar boas decisões. Em suas defesas, respectivamente, da supremacia judicial e da supremacia legislativa, Dworkin e Waldron também se utilizam, entre outros argumentos, de alguns dessa natureza (a resposta certa judicial, para o primeiro, e a sabedoria da multidão, para o segundo).

Um fato da política traz maior complexidade a essa empreitada. Segundo a sabedoria convencional, instituições, por mais bem pensadas que sejam, são falíveis. Não há como escapar, nas palavras de Rawls, da "justiça procedimental imperfeita", uma fatalidade da política. ${ }^{453} \mathrm{Com}$ base nessas premissas, o último tópico de minha dissertação de mestrado lançou mão de uma pergunta para manifestar preocupação semelhante: se auto-governo envolve o direito ao erro, e todas as instituições são falíveis, quem tem o direito de errar por último? ${ }^{454}$

\footnotetext{
have a satisfaction in the sense that we are all engaged in a common venture" (The Bill of Rights, p. 73-74); "Liberty lies in the hearts of men and women; when it dies there, no constitution, no law, no court can save it; no constitution, no law, no court can even do much to help it. While it lies there it needs no constitution, no law, no court to save it" (The Spirit of Liberty, p. 189).

${ }^{451}$ Democracy and Its Critics, p. 52.

${ }^{452}$ Posiciona-se em termos bastante semelhantes a Ely, conforme vimos no capítulo 2.

453 "The characteristic mark of imperfect procedural justice is that while there is an independent criterion for the correct outcome, there is no feasible procedure which is sure to lead to it. By contrast, pure procedural justice obtains when there is no independent criterion for the right result (...)" $(A$ Theory of Justice, p. 86).

${ }^{454}$ Controle de Constitucionalidade e Democracia, p. 187.
} 
Essa seria uma pergunta fundamental da teoria democrática, uma demanda pela localização $d a$ instituição sobre a qual recai esse ônus mais pesado. Argumentei que, dadas essas circunstâncias, e afastada a implausível "presunção da infalibilidade judicial", não haveria uma boa razão para conceder o "direito de errar por último" à corte constitucional. Não haveria boas respostas para os cenários 3 e 4 da tabela abaixo. Freqüentemente, eles são ignorados em defesas da revisão judicial.

\begin{tabular}{|l|c|c|}
\hline \multicolumn{1}{|c|}{ Passo 2 } & Corte acerta & Corte erra \\
Passo 1 & & 3 \\
\hline Legislador acerta & 1 & 4 \\
\hline Legislador erra & 2 & \\
\hline
\end{tabular}

Pode-se notar que esse argumento faz, ao menos, cinco suposições fortes: de que há última palavra; de que esta é judicial; de que o auto-governo coletivo se expressa mais fielmente em outra instituição (o parlamento); de que, sem maiores qualificações, parlamento e corte constitucional são igualmente falíveis; e de que há um critério para julgar erro e acerto independentemente do procedimento.

Este capítulo pretende relativizar algumas dessas suposições e, à luz da tensão entre as teorias da última palavra e do diálogo, reformular a questão inicial da dissertação. Trata-se de um capítulo de passagem entre a parte descritiva da tese e o seu momento mais construtivo e ensaístico. Contenta-se em fornecer a idéia de "última palavra provisória", cujas implicações os capítulos 6 e 7 procurarão desenvolver.

Comecemos pela suposição de que o parlamento é o lugar institucional prioritário do ideal de auto-governo. Essa inferência comum foi atacada pela posição descrita no capítulo 2 (última palavra judicial). Os argumentos lá presentes, mesmo que possam também ser relativizados, não devem ser subestimados. O que eles mostram, basicamente, é que o apego incondicional ao parlamento representativo como realização do auto-governo é tão perigoso quanto simplista. A representação não se esgota na eleição. Supor que a corte, simplesmente por não ter membros eleitos, é um agente externo à comunidade e longe de seu controle, como se as decisões "deles" jamais pudessem ser percebidas como "nossas", é ignorar um 
conceito mais abrangente e desejável de legitimidade. A oposição entre "povo", espelhado no parlamento, e "juízes", ofuscaria uma dinâmica política mais complexa. Cada instituição pode possuir nada mais do que "rastros de auto-governo", na expressão de Michelman, que mostrou como a ofensiva contra o fetichismo judicial traz consigo a armadilha do fetichismo legislativo. ${ }^{455}$ Como toda atitude cognitiva binária, ela faz uma defesa fundamentalista de um dos pólos.

Levado às últimas conseqüências, a adesão cega ao parlamento nega que possamos ter um critério independente para julgar a correção das decisões políticas. Nesse caso, obedecido o procedimento, presume-se que a decisão foi certa. Isso não implica numa "inversão da presunção", ou seja, em supor que a decisão de outra instituição necessariamente "corrigirá" a do parlamento. Defende-se, simplesmente, a importância de medidas valorativas que transcendem o procedimento em si, e que não se conceda a nenhuma instituição o trunfo da presunção. A perspectiva do diálogo ajuda a tornar essa idéia menos exótica. Ajuda também a perceber, conforme veremos no capítulo seguinte, que aqueles "rastros de auto-governo" não são uma qualidade estática de cada instituição, permitindo que se as hierarquize a priori, mas variam conforme o seu desempenho.

A suposição segundo a qual, diante do fato da "justiça procedimental imperfeita", todas as instituições são igualmente falíveis, é também problemática. Ela nega qualquer pretensão epistêmica, ainda que em termos probabilísticos, a desenhos institucionais. ${ }^{456} \mathrm{Em}$ vez de admitir que há estratégias mais ou menos falíveis, percebe apenas os pólos do falível e do infalível. Essa posição, obviamente implausível se generalizada para qualquer tema decisório, é também difícil de ser aceita quando se cuida de direitos fundamentais. Nesses casos, é mais evidente a necessidade de que a democracia conjugue os objetivos de auto-governo e da resposta certa, de input e output, do procedimento legítimo e da maior probabilidade de que ele produza

\footnotetext{
455 "Foreword - Traces of Self-Government", p. 75.

${ }^{456}$ Frank Michelman mostra-se sensível aos graus de probabilidade do erro, mas ainda parece opor parlamento e corte de forma excludente: "So the question is, before I beat it any further into the ground: How likely is even the most capable and favorably situated judge to make mistakes about what democracy requires of a set of basic laws and their major interpretations? If and when our estimate of that likelihood passes beyond a certain point, the institutional advantages of the judiciary start to look like a meager excuse for not letting the people bat for themselves" (Brennan and Democracy, p. 58).
} 
decisões boas. ${ }^{457}$ Mesmo que não cheguemos tão longe quanto Dworkin, para quem, em relação a direitos, o que importa é exclusivamente o resultado substantivo, a opção oposta também não é atraente.

Algum balanceamento que mostre a interdependência de forma e substância, e que valorize a interação entre corte e parlamento, parece mais convincente. No argumento da dissertação, fechei o espaço para que, por meio do desenho institucional, se pudesse minimizar a chance do erro em relação a direitos. As respostas da supremacia legislativa ou judicial não oferecem, contudo, solução satisfatória. Culminam em dilemas que não podem ser resolvidos em abstrato. Por exemplo: sem revisão judicial, o parlamento se sente mais pressionado a emitir uma interpretação constitucional adequada? A existência da revisão judicial faz o parlamento abdicar de seu papel de intérprete constitucional e deferir, ou exatamente o contrário? A corte, para autores como Thayer, seria o álibi usado pelo parlamento para desobedecer a constituição. Pickerill, mais informado empiricamente, pensa exatamente o contrário, mas também reconhece que outras variáveis devem entrar na análise para uma explicação mais completa do comportamento institucional.

$\mathrm{Na}$ perspectiva do diálogo defendida adiante, pode-se enxergar a corte e o parlamento de maneira não excludente. Não se propõe uma receita pronta e abstrata sobre o modo correto de interação das instituições, pois ela não tem como existir. É um esforço teórico infrutífero. Mais importante é encontrar critérios que permitam avaliar a legitimidade de cada instituição, caso a caso. O desafio é demonstrar que, apesar de a expertise ser variável importante no desenho institucional, no que diz respeito a direitos, o argumento epistêmico pela supremacia de qualquer instituição é indesejável. A minimização do erro não decorre tanto de uma instituição ou de outra, mas de sua interação deliberativa e da busca pelas melhores razões públicas, tanto por parlamentos quanto por cortes. Assim, pode-se potencializar a capacidade epistêmica

\footnotetext{
457 Álvaro de Vita também levanta a questão em termos de probabilidade: "Mas já é um pouco menos banal dizer que nenhuma constituição democrática, como quer que seja concebida e implementada, pode ser mais do aquilo que Rawls denomina 'justiça procedimental imperfeita'. Ainda que a escolha constitucional deva ser guiada por um julgamento sobre que instituições mais provavelmente produzirão resultados justos, não há nenhum arranjo institucional factível que possa assegurar que o processo democrático sempre produzirá resultados políticos que estejam em conformidade com um critério independente de justiça". ("Sociedade Democrática e Democracia Política", p. 8).
} 
da democracia sem negar a falibilidade das instituições. Essa idéia está melhor desenvolvida no capítulo 7.

Finalmente, a suposição de que há uma última palavra, e de que esta pertence à corte. ${ }^{458}$ As teorias expostas no capítulo anterior, por ângulos diferentes, mostram que a idéia de última palavra, e ainda mais a judicial, tem claros limites. Num caso judicial individualizado, a decisão da corte, transitada em julgado, é o ponto final, do ponto de vista jurídico, naquele caso. O tema, porém, continua a ser digerido e debatido pela comunidade política, a qual, com o passar do tempo, se manifestará novamente sobre ele em variados foros institucionais, inclusive o judicial.

Apesar disso, a perspectiva do diálogo não dilui totalmente o problema. Esse, mais uma vez, é o risco metodológico de se eliminar a tensão entre dois pólos pela adesão incondicional a um deles. O fato de que as instituições continuam a "dialogar" e de que a última palavra não é tão forte quanto parecia, não significa que a preocupação, por exemplo, de Thayer (de que a democracia possa desaquecer com ativismo judicial), seja irrelevante, que não se deva encontrar um ponto de equilíbrio. Teorias do diálogo expostas até aqui mostram a insuficiência das teorias da última palavra, mas não dão uma resposta totalmente autônoma.

Para que se possam conjugar as matrizes da última palavra e do diálogo, introduzo as noções de "rodada procedimental" e de "última palavra provisória". Seu significado é simples e auto-explicativo: toda constituição prevê os caminhos para vocalização institucional de projetos coletivos e para a solução de conflitos. Esses caminhos têm um ponto de partida e, após estágios intermediários, alcançam um ponto final. Esse ponto será final, no entanto, somente dentro de uma rodada, que pode sempre ser recomeçada, indefinidamente.

A possibilidade de recomeçar não é irrelevante para a reflexão sobre autoridade democrática. $\mathrm{O}$ recomeço, entretanto, implica em nova mobilização de diversos recursos necessários para movimentar a máquina institucional: entre outros,

${ }^{458}$ O juiz Robert Jackson, no caso Brown v. Allen, de 1953, proferiu frase de efeito pela qual reconhece que, apesar de serem falíveis, a última palavra construiria a ficção jurídica de que decidiram corretamente: "We are not final because we are infallible, but we are infallible only because we are final". 
recursos de tempo e de esforço argumentativo, importantes para os fins dessa tese. Nesse sentido, a instituição que decide por último dentro de uma rodada procedimental, ainda que possa ser desafiada em novas rodadas, nem por isso é inofensiva. Tem o poder de exigir uma nova mobilização e, portanto, de atrasar a realização de um determinado projeto. Mesmo que enfraquecido, o problema de legitimidade do detentor da última palavra não desaparece.

Considerando que diferentes modelos de diálogo decorrem de diferentes combinações entre desenhos constitucionais e culturas políticas, a distribuição de "últimas palavras provisórias" e a auto-percepção de cada instituição sobre o quanto intervir e o quanto deferir em cada momento não são escolhas de menor importância. Tangenciamos, aqui, ponto levantado por Friedman no capítulo anterior. Para ele, a questão normativa que vale a pena perseguir é a do balanço entre dinamismo e última palavra na separação de poderes, o quanto e por quanto tempo se deve permitir a dissonância entre opinião pública e a decisão judicial.

Teorias do diálogo, portanto, trazem algo de novo, mas precisam ser combinadas com a dimensão da última palavra. A pergunta original que inspira o capítulo não deixa de fazer sentido. Deve, no entanto, lidar também com a provisoriedade da última palavra. Ligeiramente reformulada, a pergunta passa a ser: quem tem o direito de errar por último, ainda que provisoriamente? Ou, em termos mais diretos: quem tem direito à última palavra provisória? 


\section{Capítulo 6}

\section{Separação de poderes e os tempos da política: diálogo ou última palavra?}

\section{Introdução}

Os excessos da teoria normativa, como vimos, produziram apoteoses da última palavra, batalhas imaginárias entre o juiz heróico e o legislador moralmente decaído, ou entre o juiz ideologicamente dissimulado e o legislador virtuoso e exemplar. Em outro nível, enxergou-se também um conflito entre os direitos fundamentais e a democracia, entre maiorias e minorias etc. Algumas teorias do diálogo, por sua vez, abaixam o tom e rejeitam uma disputa que aparenta ser ingênua. Fomentam a possibilidade de co-existência entre parlamentos e cortes constitucionais, sem a necessidade de escolher entre um e outro de modo excludente. Não se posicionam, necessariamente, sobre o modelo de melhor e de pior.

Os capítulos 2 a 4 abriram um amplo leque de argumentos favoráveis e contrários à revisão judicial. Os capítulos 6 e 7 pretendem levar em conta parte do conteúdo lá presente e inserir novas observações para esboçar uma teoria normativa do diálogo. Quero testar a possibilidade de conciliar ambas as perspectivas, de combinar a provisoriedade das decisões com a continuidade da política. Levar o ideal de "diálogo permanente" às últimas conseqüências produz um certo nonsense, certamente. O mesmo se dá, porém, com a "última palavra". A intenção do capítulo é mostrar que ambas as questões subsistem e podem complementar-se. Quanta complementaridade há, afinal, entre diálogo e última palavra? Quanto o diálogo responde à objeção democrática? Quanto arrisca obscurecer?

A invocação da idéia de "última palavra provisória" não pode esconder o custo temporal, material e intelectual de novas "rodadas procedimentais". Há graus de provisoriedade. Decisões, mesmo que possam ser revistas, são mais ou menos duradouras e resistentes. Alguns de seus efeitos se consumam e, em certo sentido, tornam-se irreversíveis. $O$ fato de ser interlocutora, por essa razão, não significa que a corte esteja isenta da responsabilidade de boas decisões e de um teste rigoroso de legitimidade. De qualquer modo, relativizar a importância da última palavra tem um valor. Se o ponto de chegada é sempre provisório, dever-se-ia atentar também para o 
caminho, o processo de interação que precede e sucede a decisão. Diálogo, no longo prazo, é inevitável. Decisões são tomadas e problemas concretos resolvidos, mas os mesmos temas são reprocessados pela comunidade política. Essa constatação trivial traz um elemento surpreendentemente novo para a reflexão sobre o papel e legitimidade do controle de constitucionalidade.

Esse capítulo segue por outros quatro tópicos. No segundo, lido com uma tradicional saída de alguns autores para evitarem uma justificativa essencialista da revisão judicial. Segundo eles, esta não é produto necessário da democracia, mas com ela também não é incompatível. Satisfazem-se em mostrar que, se a história a criou, e ela vem cumprindo função relevante, não precisamos extingui-la em função de um exercício abstrato de engenharia institucional, caminho este perseguido por outros autores. Este tópico serve para localizar os limites institucionais da teoria do diálogo aqui desenvolvida.

No tópico seguinte, procuro examinar a relação entre diálogo e última palavra, e ensaio algumas conclusões a partir de duas formas úteis que a teoria jurídica e política oferecem para lidar com o tema: a tradição da constituição mista em oposição à da soberania, e o debate entre Fuller e Hart. No quarto tópico, tento interpretar alguns postulados por meio dos quais a ciência política empírica estuda a separação de poderes e o comportamento judicial para, por último, sintetizar os pontos do capítulo e levantar outras questões normativas que serão tratadas pelo capítulo seguinte.

\section{História, instituições e teoria política normativa}

Waldron, mais de uma vez, afirmou que seus argumentos contrários à revisão judicial se dirigiam a países em que a adoção desse arranjo ainda era uma escolha em aberto. Não se destinava a participar do debate americano, onde a instituição estaria consolidada pela história e qualquer argumento que questionasse a sua existência mesma estaria fadado à irrelevância. Diversos autores já fizeram declarações parecidas para disciplinar o escopo da discussão. Dworkin, por exemplo, afirmou que "essa autoridade interpretativa já foi distribuída pela história". ${ }^{459}$ Whittington não

459 “this interpretive authority is already distributed by history" (Freedom's Law, p. 34) 
deixou de observar que a revisão judicial é "uma realidade institucional e histórica, independentemente de qualquer crítica acadêmica contra ela". ${ }^{460}$ Friedman qualificou ligeiramente essa constatação, e enfatizou que mesmo que fosse factível desenhar as instituições de maneira diferente para que espelhassem mais fielmente um ideal político puro, "é improvável que o judiciário federal sofra uma transformação dessa magnitude num futuro próximo". ${ }^{461}$ Vermeule e Garrett, por fim, propõem que a forma mais produtiva de contribuir para essa discussão não é insistir na crítica das "macro-escolhas institucionais". Aperfeiçoamentos e inovações, no presente, viriam pelas margens, na micro-escala dos procedimentos internos de cada instituição. ${ }^{462}$ Outros também se utilizam desse recurso como ponto de partida: as instituições estão aí e temos que fazer delas o melhor que pudermos. Todas essas afirmações situam-se no contexto americano, é verdade, mas me interessa aqui destacar o tipo de argumento, de resto presente em outros países também.

Zurn chama essa atitude, conforme mencionado no capítulo 1 , de "panglossianismo institucional": assume-se que determinado arranjo é um dado imutável. ${ }^{463}$ É um dos poucos autores que participam do debate sobre revisão judicial sem se intimidarem diante da matriz congelada da separação de poderes. Zurn faz ficção institucional sem acanhamento e propõe arranjos que mudam significativamente a operação da revisão, de modo a torná-la mais democrática.

Ambas as posturas são possíveis para tratar do tema da legitimidade política e sua conexão com instituições específicas. A primeira se adapta melhor, talvez, a tempos de estabilidade, lentidão e monotonia democrática. Diante da improbabilidade da mudança no horizonte próximo, trabalha com o que tem. A segunda pode conseguir alguma influência em tempos de ruptura revolucionária, ou de transições de regime em maior escala. Não são poucos os exemplos desse impacto do pensamento

\footnotetext{
460 "Judicial review is an institutional and historical reality, regardless of any academic critiques directed against it". ("Extrajudicial Constitutional Interpretation", p. 848)

461 "It might be feasible to design things differently, but the federal judiciary is not likely to receive an overhaul of this magnitude anytime soon". ("The Politics of Judicial Review", p. 332)

462 "Institutional Design of a Thayerian Congress".

463 "The idea here is that the established institutions and practices of the United States political system are to be accepted as, in the main, unchangeable social facts, and that any comprehensive constitutional jurisprudence should be able to justify their main structures and features as being close to "the best, in this the best of all possible worlds"'. Mais adiante, Zurn cita a síntese de Stephen Perry sobre o assunto: "For us, the live questions about judicial review are about how the power of judicial review should be exercised". (Cf. Deliberative Democracy and the Institutions of Judicial Review, p. 9-10)
} 
na história política moderna, repleta de revoluções que tentaram, deliberadamente, romper com práticas do passado.

Essas posturas não correspondem, necessariamente, ao que Mill diagnosticou como duas concepções conflitantes sobre as instituições políticas: um produto de pura arte prática e invenção humana premeditada; ou uma decorrência espontânea e natural da história, imune ao controle racional. ${ }^{464} \mathrm{Ou}$, para usar de um senso comum histórico, de um lado, o estilo do jacobinismo institucional francês, que olha para a frente e se dispõe a recomeçar do zero, somente com o auxílio da razão; de outro, o incrementalismo britânico, que olha para trás e valoriza a tradição.

Os autores citados acima simplesmente adotam duas estratégias diferentes na construção da teoria política normativa. Os primeiros (com Dworkin etc.) não caem no fatalismo conservador, nem negam que instituições são produto de escolha, em alguma medida, mas preferem contribuir para o aperfeiçoamento daquele arranjo que já existe. A segunda postura tampouco defende uma reconstrução ex nihilo, mas apenas tenta vislumbrar a possibilidade de reformas mais amplas. E provavelmente é mais otimista quanto ao impacto que o pensamento normativo pode produzir em tais reformas.

Essa é uma primeira forma de conceber a relação entre instituições, história e teoria política normativa. Avalia-se o quanto a mudança institucional, caso desejável em princípio, é factível, e formula-se proposições normativas mais ou menos pretensiosas a partir dessa avaliação. ${ }^{465}$ Quanto a essa dimensão, esta tese opta por pensar na relação entre instituições existentes, ou, mais especificamente, entre corte constitucional e parlamento representativo. Não é meu objetivo, nesse sentido, avaliar alternativas de macro-reformas institucionais que aperfeiçoem a prática do diálogo (como a adoção, por exemplo, de um mecanismo formal de "resposta legislativa", semelhante ao do Canadá).

\footnotetext{
${ }^{464}$ Considerations in Representative Government, p. 205-207.

${ }^{465} \mathrm{Ou}$ então, despretensiosamente, elabora-se uma teoria sem a expectativa de que surta efeitos no curto prazo (ou mesmo em qualquer outro momento, enfim). Como afirmou Cícero de Araújo: "Toda reflexão política brota de seu próprio contexto, mas não está fadada a morrer ali, só porque não logrou deitar raízes na realidade histórica imediata”. (Fundações da República e do Estado, p. 184)
} 
O fato do diálogo, por si só, não fornece uma justificativa positiva para a existência da revisão judicial (independentemente de todas as outras formas imagináveis). Claro que poderíamos especular uma instituição ideal que desempenhasse, eventualmente, a função da revisão de maneira mais legítima e competente que a corte. Talvez a corte não tenha os melhores incentivos ou a capacidade para cumprir o papel que a teoria da legitimidade esboçada nessa tese lhe atribui. Mas abrir a janela para imaginar outras instituições exigiria seguir caminho diferente do escolhido aqui.

Portanto, fazemos uma concessão à história para tentar ver o modelo vigente sob a melhor luz possível, sem prejuízo de que outras análises mostrem que ele pode ser aperfeiçoado, redesenhado etc. Não se trata de "panglossianismo institucional", mas apenas do estabelecimento de um ponto de partida. Pensar em condições que maximizem a legitimidade das cortes é estratégia mais fecunda do que rejeitar, por princípio, a possibilidade da existência de uma instituição que nas últimas décadas ocupou um espaço antes inimaginável na estrutura de poderes. Mais fecunda, também, do que aceitá-la sem maiores qualificações, como ocorre, ao meu ver, com a posição que ataquei na dissertação. Como tentarei defender no capítulo 7, o diálogo pode ser desempenhado de diferentes maneiras, e algumas delas trazem, inclusive, boas justificativas positivas para esse arranjo.

A oposição entre "última palavra" e "diálogo" suscita, ainda, outro prisma da relação entre história e instituições. Permite olhar para duas escalas temporais de um regime: a demanda imediata por uma decisão, e a sucessão de decisões ao longo do tempo (curto e longo prazos, para simplificar em duas categorias genéricas). Por meio da separação de poderes, ademais, pode-se notar essas duas escalas temporais não através de uma instituição tomando, sozinha, decisões ao longo da história, mas de diferentes instituições interagindo (no caso desta tese, parlamentos e cortes). O terceiro tópico abaixo lida com esse foco.

Para terminar, há um terceiro prisma para conceber a relação entre história e instituições. Refiro-me à construção, por meio de continuidade e gradativo enraizamento, da legitimidade e da reputação das instituições. A longevidade institucional traz um valor adicional a ser considerado, do ponto de vista empírico e 
normativo. O quarto tópico tangencia essa perspectiva trazendo algumas constatações da ciência política empírica. Percebe-se, ali, que a legitimidade não é somente produto de uma receita abstrata e ex ante da separação de poderes, mas depende do desempenho que instituições consigam atingir (perspectiva ex post).

\section{Pesos e medidas da última palavra}

O diálogo inter-institucional é forjado por dois componentes básicos: (i) o desenho institucional que o disciplina formalmente e (ii) a cultura política que o anima. Como dito acima, a tese não se preocupa com desenhos institucionais específicos. Não defendo um modelo mais desejável de separação de funções e da revisão judicial (se o "forte" norte americano, o "fraco" canadense, ou o "mínimo" britânico ou neo-zelandês), pois desconfio que soluções abstratas e de pretensão universal não atendem demandas institucionais particulares. Não nego que este desenho seja relevante, também, para incentivar padrões melhores de interação e deliberação. No entanto, priorizo um passo anterior. Quero demonstrar que, seja qual for a arquitetura institucional: (i) a interação no tempo (em variados intervalos, de acordo com o modelo) é incontornável, o que não é irrelevante para entender o problema da legitimidade; e (ii) as concepções variadas de legitimidade que informam a respectiva cultura política e interferem na qualidade dessa interação. Reservo este segundo ponto para o próximo capítulo. Tratemos do primeiro.

O ponto de partida da tese é uma conhecida objeção democrática à revisão judicial. Se reagimos a ela dizendo que não há última palavra, mas diálogo permanente entre diferentes instituições políticas que são capazes de responder às decisões umas das outras, aquela objeção deixa de ser tão trágica. Vista a partir desse ângulo, a revisão judicial é apenas um estágio decisório a mais. Essa resposta, todavia, é insatisfatória. Permite-nos, provavelmente, voltar ao problema original com uma percepção mais nuançada do(s) tempo(s) da política e um senso de sua continuidade. No entanto, não nos diz muito sobre a legitimidade da interferência de diferentes instituições, em momentos diversos, nesse processo. Não justifica, por si só, os custos que tais decisões podem impor sobre a "vontade democrática" (caso se considere correta a premissa daquela objeção - que o parlamento é o lócus central da democracia). 
Para lidar com essa dificuldade, lancei mão, no último capítulo, de dois recursos. Cada constituição estabelece um modelo de interação e escolhe a instituição detentora da "última palavra provisória" (com graus diferenciados de resistência). Novas "rodadas procedimentais" poderão sempre ser iniciadas. Assim, tento escapar de duas armadilhas binárias que se insinuam na literatura aqui sistematizada (ou parlamentos ou cortes, ou última palavra ou diálogo) e investigar a complementariedade entre eles. Identifico nos sub-tópicos abaixo dois enquadramentos interessantes de tal relação.

\subsection{Entre constituição mista e soberania?}

A oposição entre "diálogo" e "última palavra" ecoa a tensão clássica entre constituição mista, reconcebida e renomeada por "separação de poderes" pela teoria política moderna, e soberania. Essa afinidade me parece correta, mas merece algumas qualificações. Não pretendo, aqui, desviar o argumento simplesmente para trazer uma curiosidade histórica, mas indicar que, nas raízes da própria idéia de separação de poderes, a última palavra, ou o lócus da "autoridade soberana", não era uma questão que se colocava.

Na sua origem, a constituição mista corresponde à mescla das formas simples de governo (governo de um, de poucos e de muitos). Buscou promover um equilíbrio das forças que emergiam dos "impulsos da realeza, da aristocracia e do povo". ${ }^{466}$ Dito de outro modo, surgiu como um ideal de equilíbrio de poderes entre diferentes grupos dentro de uma sociedade hierarquizada e estamental. Não estava associada, ainda, a um esquema de divisão de funções institucionais, ao modo dos "freios e contrapesos". Pressupunha uma sociolgia. Cada agência de poder, por isso, se definia pela ordem

\footnotetext{
${ }^{466}$ Cícero de Araújo, Fundações da República e do Estado, p. 12 e 23
} 
social que a dominava. ${ }^{467}$ Institucionalizou-se o desacordo como um meio de manter a capacidade criativa e transformadora da política. ${ }^{468}$

Essa tradição tem dificuldades de se compatibilizar com o advento do estado soberano moderno. Hobbes, por exemplo, rejeita-a e defende a necessidade de um último soberano que combata os perigos do vácuo político, da ausência ou da multiplicidade de autoridades e da anarquia. Nessa visão estatista, a "única soberania inteligível é aquela em que o soberano é supremo e indivisível" ${ }^{469}$ Há, de cada lado, recomendações opostas de desenho institucional: uma, verticalizada, com o cume da autoridade claramente definido; outra, horizontalizada por meio de mecanismos que possibilitam a co-existência sem uma autoridade suprema.

O episódio de fundação da constituição americana é referência obrigatória dessa tradição na modernidade. Representa o momento em que o mecanismo de freios e contrapesos, entendido como divisão funcional de poderes, nasce mais claramente, algo que ainda não estava em Montesquieu. ${ }^{470}$ Não adianta a constituição estabelecer limites no papel - essa era a principal mensagem dos Federalistas sobre a separação de poderes como mecanismo de preservação da liberdade. A solução teria que ser endógena, com o poder controlando o próprio poder. ${ }^{471} \mathrm{~A}$ máquina decisória ali desenhada cria uma dinâmica política inovadora e flexível. No entanto, sua gramática não aceita muito bem a necessidade de identificar $o$ locus do poder soberano (ao

\footnotetext{
${ }^{467}$ Cícero de Araújo, ao descrever essa acepção de conteúdo social da constituição mista no governo romano: "De qualquer modo, ali se aplica, para um governo concreto, uma idéia que se tornará preciosa no futuro: que a constituição mista, a fim de melhor promover a estabilidade, pode conter um sistema de agências que, ao mesmo tempo, contrapõem-se e cooperam entre si - um sistema de freios e contrapesos, para usar a imagem mecânica popular de nossos dias, que Políbio mesmo não emprega. Mas a indicação está lá". (Fundações da República e do Estado, p. 22)

${ }^{468}$ Cf David Wooton, 'Liberty, Metaphor, and Mechanism: 'checks and balances' and the origins of modern constitutionalism".

${ }^{469}$ Fundações da República e do Estado, p. 130.

${ }^{470}$ Em Montesquieu a separação de poderes ainda está associada à hierarquia estamental. Nos Federalistas, monta-se uma maquinaria governamental que não se conecta diretamente com a suposição de uma sociedade dividida rigidamente. Cícero de Araújo mostra, porém, que isso não significa que ali tenha sido formulada uma teoria "esvaziada de conteúdo social", o que se verifica mais claramente na solução que Madison dá para o problema das facções (um produto de interesses econômicos antagônicos). (Cf. Cícero de Araújo, p. 162-163)

${ }^{471}$ Para Friedman, o maior legado dos Federalistas não teria sido a constituição, mas a teoria que a faz funcionar e adaptar-se a circunstâncias diversas. ("Dialogue and Judicial Review", p. 625)
} 
menos do ponto de vista interno). ${ }^{472}$ Como diz Cícero de Araújo, esse locus é uma "questão em aberto". ${ }^{473}$

Dando um salto adiante, as democracias contemporâneas despertam certa perplexidade por essa razão. Incorporam a noção de soberania e a transferem, conceitualmente, ao povo. Na prática, porém, organizam-se numa complexa estrutura de freios e contrapesos (ou seja, sem uma noção unívoca de soberania interna ${ }^{474}$ ). Como conciliar "soberania do povo" com "separação de poderes"?

Uma saída possível seria localizar o "povo" dentro de um poder constituinte originário, uno e fundador, que se apaga na política cotidiana. Essa linha, porém, como vimos nos capítulos anteriores, não agrada a todos, e aplica um ideal de "soberania do povo" talvez fraudulento. Outra alternativa seria localizar o povo dentro de uma das instituições, a qual passaria a ser o ápice dessa estrutura. Qualquer decisão que contrarie escolhas da instituição soberana por excelência seria, assim, antidemocrática. Mas essa solução esconde ruídos que a lógica da separação de poderes não tem como evitar. Descrever a co-existência de uma pluralidade de fontes de autoridade por meio do conceito de soberania é tarefa extremamente controversa, cuja saída normativa costuma estar associada ao ideal de que os poderes encontrem formas de "cooperar", 475

\footnotetext{
${ }^{472}$ Cícero de Araújo, Fundações da República e do Estado, p. 55.

473 "Para ser exato, uma doutrina da divisão/separação dos poderes constitucionais do tipo checks and balances, também pode se apresentar sob o invólucro da forma Estado. Contudo, o caráter intrínseco de sua soberania traz consigo a noção de um cume do processo decisório constitucional, e isso não se. encaixa bem no espírito da doutrina. A figura do soberano estatal é também a figura da última instância decisória, contra a qual não há recurso nem controle. Mas a idéia de um soberano normativamente limitado ou contrarrestado por outros poderes, como bem sublinha Hobbes, é contraditória com esse conceito. Assim, sob os auspícios da soberania intrínseca, a doutrina da divisão de poderes acaba tendo de apontar a instância de último recurso que cumpra o papel do soberano, caso os poderes não convirjam para um mesmo ponto. Porém, o espírito da separação de poderes é deixar essa questão em. aberto". (Cf. "Representação, Retrato e Drama", p. 252) Em outra passagem, afirma: "A Constituição Mista não tem nada a objetar, ao contrário, só a estimular que haja diferentes centros decisórios, cada qual podendo reivindicar divergentemente a representação do Povo, desde que este não seja pensado como um ente homogêneo apto a providenciar um self inequívoco à representação" (p. 257).

${ }^{474}$ Cícero de Araújo, Fundações da República e do Estado, p. 61.

475 "Pois se há uma questão continuamente pendente na teoria constitucional, é a de identificar o locus inequívoco do soberano reclamado por aquele conceito: ainda que se possa salvá-lo assinalando, em princípio, o momento e a responsabilidade específica na qual essa ou aquela agência governamental se apresentaria como 'o soberano', a teoria acaba cedendo à noção normativa de que ou os poderes constitucionais encontram maneiras de 'cooperar' uns com os outros, ou a ordem política sucumbe à paralisia”. (Cícero de Araújo, Fundações da República e do Estado, p. 239)
} 
Parece-me que a questão, assim formulada, é bastante semelhante àquela de que trato neste trabalho. Essa tradição é um horizonte teórico de fundo que ilumina o meu problema. Nesse tópico, contudo, quero testar a complementariedade entre diálogo e última palavra, e a referência dos freios e contrapesos não capta exatamente a dimensão temporal que procuro destacar. Fuller e Hart acrescentam algo a essa relação.

\subsection{Entre Fuller e Hart?}

O debate entre Fuller e Hart é um episódio inspirado da teoria do direito do século $\mathrm{XX}^{476}$ Acredito que a possibilidade de conciliação entre eles diz algo sobre como entender a co-existência de "diálogo permanente" e "últimas palavras provisórias". Esse debate, naturalmente, envolve um conjunto grande de argumentos e conceitos. Quero apenas pinçar duas definições gerais para levar adiante a tarefa que propus aqui: o direito concebido como um "empreendimento teleológico" e o direito visto como "fato social". Entendamos um pouco melhor os termos desse aparente conflito.

Hart intenta descrever o direito na posição de um observador externo que olha para um determinado fenômeno social. A partir desse ponto de vista, ele nota que o elemento distinto do direito, em relação a outros fenômenos normativos, não são as regras de conduta, que impõem deveres (as quais ele chama de primárias), mas as regras que conferem poderes e faculdades (as secundárias, já brevemente mencionadas no capítulo 1). Num estado de direito, basicamente, agentes públicos obedecem regras secundárias, em boa medida. Sem regras secundárias (onde não há autoridades definidas e as regras de conduta correspondem a práticas sociais dispersas), um estado de direito ou não atingiu a maturidade ou encontra-se em crise. Segundo ele, esse é um fato que se constata, não que se avalia. Descrever o direito tal como ele é não impede que se lance mão da "moralidade crítica" para julgá-lo, ou que se defendam visões sobre como ele deve ser, e a partir daí estimular a sua reforma.

\footnotetext{
${ }^{476}$ Esse diálogo começa com o artigo de Hart, "Positivism and the Separation of Law and Morals" (1958), ao qual Fuller responde com "Positivism and Fidelity to Law" (1958); no livro Concept of Law (1961), Hart retoma diversos dos temas, aos quais Fuller responde em The Morality of Law (1964), resenhado criticamente por Hart, cujas críticas, finalmente, foram respondidas por Fuller num apêndice à segunda edição de seu livro (1969).
} 
Misturar "ser" e "dever ser", todavia, tem o efeito perverso de dificultar a tarefa de identificar o direito com clareza, de criticá-lo e, caso se deseje, aperfeiçoá-lo. ${ }^{477}$

Fuller apresenta uma versão diferente. Para ele, o estado de direito não "é", simplesmente. Ele "tem que ser". Corresponde a uma conquista, uma perseguição contínua de um propósito: submeter o comportamento humano a regras. Não se trata de um fato, mas de um objeto do esforço humano, gerenciado ininterruptamente por meio das habilidades de uma arte prática. Sua existência é uma questão de grau ${ }^{478}-$ de maior ou menor sucesso no atingimento daquele propósito.

Para buscar o objetivo de sujeitar o comportamento humano a regras, o direito tem que respeitar a uma moralidade interna (que ele chamou de "jusnaturalismo procedimental", em oposição à moralidade externa, o "jusnaturalismo substantivo"479). Compõe tal moralidade o seu festejado conjunto de oito parâmetros necessários para a produção de regras capazes de serem obedecidas (generalidade, não-retroatividade, clareza etc. ${ }^{480}$ ). Tal moralidade interna do direito, sem a qual ele não consegue existir em grau mínimo, é um exemplo de "moralidade de aspiração", aquela que estabelece padrões de excelência que nunca são totalmente atingidos, mas que apontam as metas que orientam nossas escolhas. ${ }^{481} \mathrm{O}$ direito precisa ser visto como um empreendimento teleológico que depende, para o seu sucesso, da energia e da inteligência daqueles que o conduzem. Se visto como um simples fato de autoridade, perde-se a dimensão do que ele está "tentando fazer" ${ }^{482} \mathrm{O}$ ideal de fidelidade ao direito, portanto, necessita de planejamento. ${ }^{483}$ Não é mera coincidência

\footnotetext{
${ }^{477}$ Cf. "Positivism and the Separation of Law and Morals".

478 "[Hart is wrong] to treat law as a datum projecting itself into human experience and not as an object of human striving. When we realize that order itself is something that must be worked for, it becomes apparent that the existence of a legal system, even bad or evil legal system, is always a matter of degree". ("Positivism and Fidelity to Law", p. 646) "If law is simply a manifested fact of authority or social power, then, though we can still talk about the substantive justice or injustice of particular enactments, we can no longer talk about the degree to which a legal system as a whole achieves the ideal of legality". (The Morality of Law, p. 147)

${ }^{479}$ The Morality of Law, p. 102.

${ }^{480}$ The Morality of Law, p. 46 e ss.

${ }^{481}$ Moralidade de aspiração se opõe à moralidade do dever, esta preocupada com as exigências mínimas sem as quais torna-se impossível a convivência social.

${ }^{482}$ The Morality of Law, p. 145.

483 "For I believe that a realization of this ideal is something for which we must plan, and that is precisely what positivism refuses to do. (...) planning the conditions that will make it possible to realize the ideal of fidelity to law". ("Positivism and Fidelity to Law", p. 642-643)
} 
a enorme preocupação que Fuller tem com as técnicas de desenho institucional. A concepção de Hart ignoraria esse fenômeno social mais complexo. ${ }^{484}$

Suspeito que, por baixo do desacordo que eles mesmos insistem em verbalizar, tais autores estejam falando de coisas diferentes, orientados por objetivos teóricos diversos. Hart não necessariamente nega que o conjunto de técnicas para manter o fenômeno jurídico em funcionamento precisa de empenho contínuo daqueles que fabricam tais regras. Ele simplesmente aponta que o direito não pode existir, antes de tudo, sem referência precisa a quais são as fontes de autoridade e a uma prática social de obediência a elas. Fuller, de outro lado, alerta para o perigo de ver isso como um dado pronto e acabado, e lembra da importância de perceber o engenho humano subjacente a esse fenômeno (a "conquista" por trás do "fato").

Ver o direito como um fato presente ou como um empreendimento contínuo, como mera localização de autoridade ou como um projeto que precisa ser administrado, destaca, ao meu ver, os dois componentes da relação que estamos estudando aqui. Chama a atenção, em especial, para duas perspectivas temporais por meio das quais podemos observar a política e o direito: a sincrônica e a diacrônica. $\mathrm{Na}$ primeira, importa saber quem decide uma demanda, aqui e agora; na segunda, qual o norte que propicia a continuidade, a manutenção e o auto-aperfeiçoamento daquela autoridade que decide quando é chamada.

Associar, mecanicamente, Fuller à perspectiva do diálogo e Hart à da última palavra pode cometer alguma imprecisão e cometer injustiça às suas respectivas teorias. Mas o esforço de lê-los por essa lente, apesar do risco da interpretação forçada, ajuda-nos a perceber duas metas paralelas de um estado e, no nosso caso, da democracia constitucional. Por mais que a última palavra cumpra função imprescindível, talvez não seja somente por aí que a pergunta sobre a legitimidade de um regime deva ser formulada.

\subsection{Graus de ansiedade por autoridade: a última palavra importa?}

\footnotetext{
484 “(...) Hart leaving completely untouched the nature of the fundamental rules that make law itself possible". ("Positivism and Fidelity to Law", p. 639)
} 
"Ninguém tem a última palavra porque não há última palavra". ${ }^{485} \mathrm{~A}$ frase de Hanna Pitkin serviu como epígrafe da tese. Ao proferi-la, a autora não estava discutindo o problema da revisão judicial. Fora do seu contexto, de qualquer modo, tal passagem me fornece uma síntese provocativa para tentar coletar os pedaços espalhados pelo texto e fechar algumas conclusões iniciais.

Até aqui, o capítulo deu algumas voltas. Tateou algumas formas de livrar a discussão do peso da última palavra. Sua importância está inflada e desbalanceada na literatura hegemônica da teoria constitucional. Não me parece ser o elemento que define se um regime é mais ou menos democrático, conforme tentarei aprofundar no restante desse capítulo e no próximo.

Essa obsessão produziu um efeito teórico diversionista, que reduziu a análise de legitimidade a uma busca por quem seria detentor da autoridade mais alta. Seria uma imposição da lógica elementar da autoridade: se não há acordo sobre determinado tema coletivo, algum procedimento decisório precisaria resolvê-lo. Foi com base nessa "regra de ouro" da política que Waldron formulou o ataque à revisão judicial que já nos é familiar. Num certo sentido, entretanto, tal regra de ouro não se aplica. ${ }^{486}$ A política é uma seqüência ininterrupta de contestações e revisões das decisões de autoridade. Isso não é regressão ao infinito, mas continuidade histórica.

Não se trata, a rigor, de deixar a demanda de autoridade "em aberto", o que causaria um desconforto existencial insuportável nos autores mais ansiosos por autoridade. Não tolerariam a incerteza de um regime no qual decide quem quer, ou no qual, alternativamente, ninguém decide, situações com as quais é difícil lidar com serenidade. ${ }^{487}$ A separaração de poderes admite, porém, que a cada momento decida uma agência diferente (ou que, como veremos no próximo tópico, a decisão final seja uma espécie de combinação da posição de mais de uma agência). Talvez isso seja menos grave do que as duas hipóteses anteriores.

\footnotetext{
485 "No one has the last word because there is no last word". ("Obligation and Consent-II", p. 52)

486 "Unless we envisage a literally endless chain of appeals, there will always be some person or institution whose decision is final. (...) People disagree, and there is need for a final decision and a final decision-procedure". ("The core of the case", p. 1400, 1401)

${ }^{487}$ Para alguns autores relatados no capítulo 4, como vimos, o diálogo serve apenas para garantir a resposta legislativa, ou seja, a última palavra do parlamento. Outros, porém, estão mais preparados para aceitar a inexistência, num certo sentido, da última palavra.
} 
De uma certa maneira, apontar para a provisoriedade das decisões chega a ser banal. No limite, é óbvio que a existência de leis, instituições, regimes políticos, vidas humanas, sociedades etc. é provisória, e que, nesse meio-tempo, precisamos de decisões que regulem condutas, elaborem políticas e estabeleçam padrões de convivência. É fundamental, por isso, que instituições possam atender a essa demanda. A construção delas terá de recorrer, como sempre, a um balanceamento entre os diversos valores em jogo, que permita a mudança sem, ao mesmo tempo, facilitá-la a ponto de comprometer um grau mínimo de estabilidade.

Minha busca, portanto, não é por dispensar a última palavra, mas por descobrir o seu papel teórico remanescente. Situá-la, ao menos dentro de uma rodada procedimental, é uma escolha institucional necessária e não trivial. Dependerá de qual balanceamento entendermos ser mais desejável, do grau de resistência à mudança que queremos dar à última palavra provisória (em especial, aquela que trata de direitos, o mote da tese), da estimativa do preço que vale a pena pagar pelos seus custos, do cálculo do que ganhamos e do que perdemos.

Numa seqüência de perguntas e respostas, talvez consiga sintetizar sem mais rodeios: A última palavra sobre direitos importa? Sim, mas menos do que se supunha. Importa para quê? Para firmar decisões com pretensão de maior durabilidade; para resolver, ainda que temporariamente, uma demanda por decisão coletiva que valha para todos. Qual, então, o critério para a escolha da autoridade detentora dessa prerrogativa? A confiança da comunidade na instituição que tenha maior probabilidade de produzir a melhor decisão. E se essa instituição for, comparativamente, menos democrática do que as alternativas? Mesmo que se aceite a hipótese da qualidade mais ou menos democrática de instituições isoladas, dentro da lógica da separação de poderes, aquela que for "mais democrática", caso discorde, sempre poderá responder. Se outra, de fato, for "mais democrática", dificilmente poderá será derrotada por muito tempo.

A última palavra, portanto, é apenas parte da história, não toda ela. Mas, então, o que mais importa? Quais as conseqüências de se dizer o óbvio - a sua provisoriedade, em alguma medida, incontornável? Entendo que há ganhos cognitivos 
relevantes. Relacionam-se, provavelmente, às preocupações de Fuller. O principal deles é habilitar-nos a perceber diferentes escalas temporais da democracia, o que chamei, em parágrafo anterior, de senso de continuidade. Outro, certamente, é uma recomendação básica de desenho institucional: na separação de poderes, não há um monopólio de decisões sobre direitos localizado numa das partes. Esse foco é contraproducente. A forma como essas partes interagem e, juntas, vão gradualmente construindo soluções jurídicas estáveis tem potencial promissor de investigação. Antes que tentemos, finalmente, extrair conclusões normativas de todas essas considerações, o próximo tópico acrescenta mais elementos ao problema.

\section{Reatividade política, acomodações prudenciais e flutuações de legitimidade}

Se, por um lado, o mito da neutralidade judicial já foi quebrado há bastante tempo por diferentes escolas, o da independência judicial sobrevive e continua ignorado pela teoria normativa (seja pelos que a celebram, seja pelos que lamentam e criticam sua ilegitimidade democrática). Muitos admitem que o juiz decida conforme convicções políticas e ideológicas. Dworkin, por exemplo, constrói sua teoria da leitura moral da constituição e do direito como integridade a partir dessa premissa (o que não significa, para ele, que não existam outros limites da razão). Não aceitam ou não notam que o comportamento judicial seja determinado, contudo, por constrangimentos políticos externos. Ou seja, se a corte é cercada por todo um aparato procedimental para garantir independência em relação à política eleitoral, o juiz está limitado, para os mais otimistas, unicamente pelo direito, e, para outros, nem isso.

Passo a filiar-me a três teses que a ciência política empírica tem defendido sobre o comportamento judicial. São teses que rompem esse segundo mito. Não pretendo entrar nas variações e na sofisticação dos variados modelos de análise existentes. Registro apenas o mínimo que eles compartilham: (i) a corte é politicamente sensível e testa, de modo ininterrupto, o espaço que pode ocupar na separação de poderes a partir do cálculo da resposta potencial dos outros poderes às suas decisões, e de sua força e capacidade para resistir; (ii) a separação de poderes é um fenômeno dinâmico, e uma norma jurídica abstrata não tem como descrever ou capturar essa constante redistribuição de fronteiras; (iii) em paralelo a essa interação, a própria legitimidade de cada participante do jogo também oscila, e tal oscilação é 
responsável, inclusive, pelo espaço maior ou menor que o poder irá ocupar no arranjo de forças.

Reatividade política, acomodações prudenciais e flutuações de legitimidade são um fenômeno que os Federalistas ${ }^{488}$ arquitetaram e pesquisas empíricas comprovaram. ${ }^{489}$ Poderes usam de prudência para testar até onde podem ir. Trata-se de um juízo de ocasião e de medida. O retrato da separação de poderes é, a cada momento, diferente. Não se participa de modo bem sucedido desse jogo sem as qualidades, nas palavras de Bickel, de um “animal político".

A corte constitucional, nesse sentido, não está numa torre de marfim, mas no calor da política. Mesmo que métodos de interpretação não constranjam juízes tanto quanto esperávamos, a política (formal e informal) o faz. Juízes farejam o grau de aceitabilidade de suas decisões e estão sujeitos a pressões difusas e específicas. Recorro a alguns exemplos históricos que ilustram essa idéia. Extraio tais exemplos, intencionalmente, não da literatura de ciência política, mas de uma coletânea de artigos que tentou comparar tradições de interpretação constitucional. ${ }^{490} \mathrm{~A}$ insuficiência das categorias jurídicas para explicar fenômenos de maior ou menor ativismo das cortes torna-se bastante evidente na leitura deste livro. Seus artigos limitam-se, praticamente, a classificar o método da corte como "formalista" e "positivista" quando ela toma decisões contidas, ou como "teleológico", "sociológico", "estruturalista" etc. quando avança para decisões mais ousadas. Não articulam razões políticas para explicar por que cortes mudaram entre um e outro pólo, apesar de, curiosamente, narrarem os fatos por trás dessas mudanças. ${ }^{491}$ Não verbalizam esses plausíveis nexos causais, mas permitem que o leitor as especule.

Aos exemplos. As constituições e as respectivas cortes constitucionais da Alemanha (pós-guerra) e da África do Sul (pós-apartheid) nasceram com uma característica comum: num ambiente de profunda desconfiança dos órgãos políticos

\footnotetext{
${ }^{488}$ Cf. O Federalista n. 47-51 (teoria da "inter-branch interaction" de Madison).

${ }^{489} \mathrm{Em}$ diferentes vertentes como as relatadas no capítulo 4, especialmente por Barry Friedman e pela corrente da construção coordenada.

${ }^{490}$ Jeffrey Goldsworhty (ed.), Interpreting Constitutions. Escrevi uma resenha desse livro, de onde extraio alguns desses exemplos.

${ }^{491}$ Apenas Mark Tushnet, no relato sobre a Suprema Corte americana, suscita a hipótese cética: "none of the methods imposes a sufficiently powerful constraint in the mere policy preferences of interpreters". (Ibid, p. 51)
} 
eleitorais, marcaram a ruptura com o passado autoritário e sinalizaram para um programa de extensa transformação social no futuro. As respectivas cortes, desde então, ocuparam papel de destaque na promoção de direitos. ${ }^{492}$ A corte constitucional indiana traz um exemplo mais claro da conexão entre a opção interpretativa e a atmosfera política. Desde a independência do país, e ainda embebidos na cultura constitucional britânica de soberania do parlamento, a corte constitucional teve papel tímido durante algumas décadas. Na década de 70 , contudo, a situação se inverteu à medida que o governo autoritário de Indira Ghandi fez a reputação dos órgãos representativos decair. Criou-se um vácuo político oportuno para que a corte transformasse sua imagem de órgão conservador e elitista na de um agente relevante na proteção de direitos. É dessa época a decisão extremamente interventiva de controlar a constitucionalidade de emendas constitucionais por meio da construção da "doutrina dos atributos básicos da constituição". As três cortes mencionadas, no auge de seu ativismo, não enfrentaram objeções quanto à sua legitimidade.

Exemplo contrário nos dá o caso australiano. A postura estritamente "legalista" e contida é vista, segundo o texto, como a única maneira de a corte manter um mínimo de "independência". ${ }^{493}$ No único momento em que a corte ameaçou maior "criatividade" - a construção de uma carta de direitos implícita, uma vez que a Austrália não dispõe de algo semelhante em sua constituição - a resistência e os ataques de todos os lados a fizeram desistir e voltar ao seu limitado lugar. A história da Suprema Corte americana, por fim, é a que fornece exemplos mais prolíficos para ilustrar os fatores políticos que conduzem a essas sístoles e diástoles judiciais. Essas oscilações pendulares foram explicadas como uma tradição de "ecletismo interpretativo".

A hipótese explicativa que o livro não formula é que cada corte testou sua legitimidade e calibrou o seu grau de intervenção conforme o ambiente e a expectativa social sobre seu papel. Tal hipótese não propõe, necessariamente, que a legitimidade da corte para ser ativista é inversamente proporcional à do parlamento, como se houvesse alguma causalidade linear, ou que o parlamento é o pólo dominante para permitir maior ou menor espaço à corte. Mas mostra, certamente, que há muito

\footnotetext{
${ }^{492}$ Ibid, pp. 320 e 339.

${ }^{493}$ Ibid, p. 145.
} 
mais variáveis em operação do que costuma defender a teoria normativa. Métodos interpretativos parecem ter sido, em todos esses casos, subprodutos para racionalizar decisões, não os seus próprios determinantes.

Essas modulações conforme as circunstâncias são compatíveis com a origem da idéia de freios e contrapesos, mas não se adaptam a uma teoria da adjudicação que se prende a uma função estática e prefixada. A operação das instituições dentro da separação de poderes é dinâmica. Elas negociam passo a passo seus raios de atuação. Mesclam atos de ativismo e contenção, ocupação e desocupação de espaço. Trata-se, sobretudo, de um processo informal (e não formalizável) de acomodações contingentes ditadas pela política, não por uma cartilha de hermenêutica (o que não significa que "política", na acepção que aplico, não seja sensível a "boas razões", ponto do próximo capítulo).

A constituição, enquanto norma escrita, é um plano de vôo que regula pouco a separação de poderes. Esta não tem como escapar de fluxos e refluxos, de exercícios de tentativa e erro em que, por aproximações sucessivas, cada instituição demarca o seu terreno. Alcançam equilíbrios instáveis, sempre sujeitos a recalibragens. Isso não é tangível nem quantificável numa norma jurídica ou numa proposição da teoria normativa. Não é possível prever constitucionalmente o momento em que uma, e não outra, gozará de maior legitimidade para tomar as grandes decisões.

Essa tese compartilha de uma teoria da separação de poderes que, no campo dos direitos fundamentais, não propõe funções estáticas, mas cambiantes. Isso está em sintonia com o que a literatura da ciência política empírica afirma sobre a decisão judicial. ${ }^{494}$ Papéis variam por baixo dos termos fixos da constituição. Esse jogo de

\footnotetext{
${ }^{494}$ Matthew Taylor, por exemplo, defende uma idéia de independência judicial em consonância com essa linha: "The model illustrates why judicial independence is not binary, is strongly influenced by political conditions, cannot be completely defined by rigidly formal 'parchment' protections alone, and may vary considerably across both time and policy arenas, even within the same political system". ("Judicial Independence", p. 3) Sobre os constrangimentos formais e informais que a corte enfrenta, afirmou: "any conception of independence must take them into account, alongside political preferences and less formal factors, such as legitimacy and long-term processes of institutional development. Because judicial independence is the result of the interplay between court preferences and the preferences of other branches of government, it is a dynamic space whose range may vary considerably, even within the same political system. Independence is thus an unstable and highly variant concept, resulting from recurring interactions that play out across both time and across different policy arenas". (Ibid, p. 5) E concluiu: "First, judicial independence cannot be considered in isolation from the interaction between courts and the conventionally political (and sometimes elected)
} 
forças, contudo, não é independente da sociedade e da repercussão de suas decisões. A opinião pública interage e é responsável por flutuações de legitimidade. Instituições constroem capital político difuso e passam a gerenciá-lo em decisões mais e menos populares. Sua margem de ação, ademais, não se define em bloco. Varia também de tema para tema, de acordo com a respectiva voltagem política do conflito. ${ }^{495}$

Apesar de a corte poder errar, e errar grosseiramente (seja qual for o critério por meio do qual se meça o erro), não é realista nem historicamente plausível dizer que ela possa decidir continuamente de modo desconectado da realidade, que ela não se preocupe com a manutenção de seu prestígio e respeitabilidade, dos quais depende não só sua legitimidade, mas inclusive a eficácia de suas decisões. Ela não consegue sustentar sua autoridade por muito tempo se insistir numa postura que não seja aceitável numa determinada cultura política.

O grau de resistência da última palavra provisória, o qual, conforme defendi no último tópico, é componente relevante das opções de desenho institucional, também está, portanto, sujeito a essas variações. Se tudo isso é verdade, como a teoria normativa pode reagir? O desafio da teoria normativa, ao meu ver, não é aprisionar as instituições num esquema rígido da separação de poderes (ou de métodos hermenêuticos), mas fazer com que o princípio regulador dessas oscilações seja permeável a "bons argumentos". O próximo capítulo tentará desenvolver mais claramente uma teoria da legitimidade do diálogo sob esse prisma. Antes, o tópico abaixo sintetiza os passos dados até aqui.

\section{Algumas conclusões e preâmbulo do próximo capítulo}

Se a tese terminasse aqui, algumas realizações mínimas, espero, já teriam sido atingidas. Tentei entender o que a forma da separação de poderes significa para a democracia constitucional. Para além de sua virtude moderadora, que é a sua justificativa tradicional, a sua gramática relativiza a última palavra, onde quer que ela esteja localizada. Talvez esta segunda virtude seja apenas a tradução da primeira, mas é importante explicitá-la para que o debate não mais se deixe seduzir por aquela 
obsessão. É necessário ponderar esse suposto ápice do processo decisório com o fato de que a luta política está fadada a continuar, e novos atos desafiarão a supremacia de uma ou de outra instituição. Significa que, em alguma medida, a extensa lista de argumentos favoráveis e contrários a cortes e parlamentos podem coexistir. Os capítulos 2 e 3 não precisam se eliminar reciprocamente. Não há que se buscar o vencedor daquela disputa. Nessa oposição excludente, algo se perde. Em vez disso, pode-se balancear tais informações numa análise de custo-benefício para o desenho de uma rodada procedimental, que é tudo que está ao alcance de um arquiteto constitucional. Definir o lugar da última palavra provisória será uma escolha pragmática, entre outras tão ou mais importantes.

A forma da separação de poderes consiste, nesse sentido, numa técnica de multiplicação dos tempos da política. Nadia Urbinati destacou um ângulo parecido em sua teoria da representação, e o empréstimo de seu argumento pode ser elucidativo, inclusive, para a conexão com o próximo capítulo. Essa autora justifica a representação como um mecanismo que faz a política superar a dimensão da vontade imediata e abrir-se para a prática do julgamento e da deliberação. De uma concepção voluntarista e unidimensional da soberania, a representação dá um salto em que a opinião, e não somente o voto, cumprem papel relevante. A presença política deixa de ter um aspecto meramente físico, e passa a se realizar também por meio da voz.

Segundo ela, a diferença entre a democracia direta e a representativa estaria relacionada, antes de tudo, ao caráter "unitemporal" da primeira em oposição à "multitemporalidade" da segunda. ${ }^{496}$ A representação teria uma especial capacidade de costurar as diferentes "camadas temporais da política", e de estabilizar o permanente processo de revogação que caracteriza a democracia. ${ }^{497}$ Seria uma solução para a "imediatidade" ou a "força desestabilizadora do presentismo". Criaria uma "soberania mediada", um continuum que une a política de curto prazo das eleições (a política do sim ou não, refém do short-termism) ao longo prazo dos ciclos

\footnotetext{
496 "Whereas immediacy and physical presence are the requirements of nonrepresentative democratic government, multitemporality and presence through voice and ideas are requirements of representative democratic government. In the former, the will devours politics in a series of discrete and absolute acts of decision. In the latter, politics is an uninterrupted narrative of proposals and projects that unifies the citizens and requires them to communicate in a given normative space and over time". (Representative Democracy, p. 225)

${ }^{497}$ Representative Democracy, p. 225.
} 
eleitorais. ${ }^{498}$ Além disso, estimularia uma circulação produtiva de idéias entre as esferas formal e informal da política.

Esse capítulo tentou mostrar, na separação de poderes, o que Urbinati ilumina na representação. Do mesmo jeito que esta é um mecanismo de circulação entre instituições estatais e as práticas sociais, ${ }^{499}$ a separação de poderes é uma ferramenta que traz essa circulação para dentro do próprio estado. Dinamizar as escalas temporais da política, contudo, não é um fim em si mesmo para Urbinati. O seu benefício é permitir a deliberação, decisões políticas que, além de sempre estarem sujeitas à revisão, também se beneficiam da troca de argumentos. A representação, nesse sentido, nos ajudaria em dois aspectos: “de um ponto de vista teórico, ilumina o lugar e o papel do julgamento na política; de um ponto de vista fenomenológico, muda a perspectiva de tempo e espaço na política, um aspecto essencial da democracia mas ainda não suficientemente estudado". ${ }^{500}$ É essa dupla-face da representação (tempo / deliberação), adaptada à separação de poderes, que orienta a divisão entre o presente capítulo e o próximo.

Apresentei aqui a inevitabilidade do diálogo, a sua manifestação em estado bruto, sem grande exigência normativa. Sempre haverá respostas, mais ou menos demoradas, mais ou menos frontais, mais ou menos custosas. "Diálogo", nesse sentido fraco da mera interação, talvez nem seja a palavra adequada, mas isso é o que menos importa. $\mathrm{O}$ fato de que os poderes interagem ininterruptamente, mesmo após últimas palavras provisórias, é suficiente para o ponto do capítulo. Escolhas institucionais não podem ignorar esses dois eixos (a finitude da rodada procedimental, e a sempre possível continuidade da mobilização política).

A dinâmica temporal da separação de poderes é o modelo dos Federalistas no seu estado puro, e traz alguns dados para entender o fenômeno da legitimidade. O capítulo 7 concebe um modelo de diálogo mais genuíno, conduzido conscientemente pelas partes. Investiga as possibilidades de explorar a separação de poderes não apenas pela sua forma, mas também pela qualidade potencial de seus resultados. Lá, a separação de poderes passa a ser descrita não mais por adjetivos indicadores de tempo

\footnotetext{
${ }^{498}$ Ibid, p. 197.

${ }^{499}$ Ibid, p. 223.

${ }^{500}$ Ibid, p. 225.
} 
como "permanente", “contínuo", "gradual”, “ininterrupto" ou "provisório", mas por adjetivos indicadores de qualidades morais, tais como "correto", "razoável", “desejável”, “justificável”. 


\section{Capítulo 7}

\section{Separação de poderes e legitimidade: deliberação inter-institucional}

\section{Introdução}

Há diálogo ou última palavra? Por meio dos conceitos de "rodada procedimental" e "última palavra provisória", tentei encontrar uma saída intermediária e conciliatória. Se o diálogo é uma perspectiva importante, qual diálogo é mais desejável na democracia? Para responder a esta pergunta, o presente capítulo conceberá "modelos de diálogo" que variam conforme o "desempenho deliberativo" de cada instituição, conceitos que aparecerão adiante. Sustento que a interação deliberativa entre os poderes tem um potencial epistêmico, ou seja, maior probabilidade de alcançar boas respostas nos dilemas constitucionais ao longo do tempo. Essa seria uma razão adicional para embarcar no projeto da revisão judicial e, ao mesmo tempo, uma condição de sua legitimidade.

Teorias sobre o papel da deliberação na democracia não costumam dedicar grande atenção para a separação de poderes, e vice-versa. ${ }^{501}$ Seria uma relação contraintuitiva: poderes não deliberam entre si, mas se controlam. ${ }^{502}$ Curiosamente, porém, instituições apresentam razões para suas decisões, de distintas maneiras. Saber se isso pode e deve ser levado em conta nas reações de outras instituições me parece uma questão teórica instigante, ainda sub-explorada.

Jeffrey Tullis se atentou para essa peculiaridade. Ele traz a idéia de deliberação para o centro da teoria da separação de poderes, uma teoria que se funda na "premissa de que nenhuma instituição democrática específica é suficiente para assegurar a consideração de todas as preocupações relevantes na sustentação da

\footnotetext{
${ }^{501}$ Jeffrey Tulis diagnostica essa desconexão entre a separação de poderes e a deliberação na teoria política: "Just as students of deliberation have overlooked separation of powers, students of the American separation of powers tend not to talk about deliberation". ("Deliberation Between Institutions", p. 208)

${ }^{502}$ Imaginar deliberação entre instituições pode acender uma desconfiança relacionada à possível suposição de existência de uma "voz institucional": Como falar sobre diálogo entre diferentes instituições se instituições são grupos de pessoas com opiniões conflitantes, se não há algo como "uma única voz", uma "intenção original", uma "mens legislatoris"? Em que sentido podemos conceber um agente supra-individual que fala, que tem opinião, que argumenta? Como instituições podem conversar consigo mesmas? A teoria jurídica oferece saídas para administrar esse problema, possivelmente conectadas à idéia de "reconstrução racional". Como, exatamente, essas duas instituições deliberam e podem falar "com uma só voz institucional" ficará para um passo seguinte desse projeto.
} 
democracia". ${ }^{503}$ Segundo esse autor, a separação de poderes faz com que diferentes valores (como a vontade popular, a linguagem dos direitos, a pressão por eficiência etc.) entrem em tensão. Dá voz institucional a diferentes perspectivas. Essa tensão deliberativa entre instituições que competem pode ser funcional para a produção de boas decisões. ${ }^{504}$

O capítulo concebe um critério de legitimidade que insere a deliberação como variável dominante. Dela se extrai uma métrica da interação institucional - o desempenho deliberativo. Defendo que parlamentos e cortes têm legitimidade para serem ativistas à medida que se engajem no diálogo. Podem optar por deferir, por esperar, ou, em face de um bom novo argumento, por desafiar o outro poder. $\mathrm{Na}$ dissertação, a revisão judicial foi caracterizada, acima de tudo, como veto temporário, como um custo temporal, e, marginalmente, como uma possibilidade de qualificar a interlocução. Nesse capítulo, quero investigar o valor subjacente a essa interlocução, a passagem de uma teoria da separação de poderes somente defensiva para uma que inclua um ônus deliberativo.

Não entrarei em detalhes de desenho institucional ou de quais seriam os melhores incentivos formais para despertar a postura que elaboro aqui, conforme alertei no capítulo anterior. Assumo apenas que a separação de poderes, entendida genericamente, carrega um princípio virtuoso para tornar a política sensível a boas razões. Mesmo que o arranjo procedimental seja parte indispensável na criação das melhores condições de deliberação, a tese se limita a destacar um parâmetro de legitimidade que valoriza esse ideal de interação.

\footnotetext{
${ }^{503}$ Ibid, p. 203.

${ }^{504}$ Este autor aponta outras duas características importantes desse tipo de deliberação. Primeiramente, a deliberação entre instituições não ocorre necessariamente ao modo face a face, mas sim, e com mais freqüência, pela troca de textos: "I think this idea, and this phenomenon, may have been overlooked because deliberation between institutions need not (though it sometimes does) involve a face to face encounter of persons. In the place of a face to face encounter (or sometimes accompanying one) are texts exchanged by institutions. In the construction and exchange of texts institutions address the merits of public policy and the best of these exchanges manifest the most important attribute of deliberation: reciprocal respect for, and responsiveness to, opposing arguments regarding the issue addressed". (Ibid, p. 202) Em segundo lugar, o desenho institucional, por si só, e sem exigir a presença de um modelo virtuoso de cidadão, pode estimular que boas razões venham à tona. Boas razões podem aflorar no furacão da competição política: "Considerable effort has been expended to define and describe the range of considerations and the kinds of arguments appropriate for democratic deliberation, but there is little discussion of institutional mechanisms to maximize the likelihood that relevant arguments, or relevant perspectives, will actually be advanced" (Ibid, p. 210).
} 
O capítulo segue por quatro tópicos. No próximo, desenvolvo com mais detalhe uma posição sobre as variáveis de legitimidade - forma e substância. Em seguida, trato do conceito de desempenho deliberativo e de como ele fornece uma medida interessante para pensar a legitimidade de cada instituição contextualmente (ex post). No quarto tópico, resgato as idéias de virtudes ativas e passivas para mostrar como, em virtude das inevitáveis flutuações de legitimidade que decorrem da separação de poderes, a corte precisa modular ativismo e deferência de forma prudente. Por fim, concebo tipos-ideais de diálogo e o respectivo potencial epistêmico.

\section{A tensão virtuosa e irredutível entre forma substância}

O capítulo anterior deixou intocadas as constatações da ciência política sobre o comportamento judicial e não problematizou suas eventuais implicações normativas. Neste capítulo, entretanto, considero importante tratá-las com mais atenção. Entender o fenômeno tal como ele ocorre é necessário para que se possa pensar nas suas condições de legitimidade. Se este fenômeno é, pelo menos em alguma medida, um dado da separação de poderes, não tanto uma escolha dos seus participantes, como lidar com ele? Se aquelas informações empíricas são verdadeiras, quais são suas conseqüências para a reflexão normativa?

A admissão de que juízes não estão presos à norma choca-se com um antigo tabu. Esse mal-estar foi atenuado por uma nova tentativa da teoria jurídica de constranger o juiz por demandas de consistência, por exigências, ao menos, de argumentação racional. A ciência política volta e denuncia a nudez do rei: o juiz constitucional é um ator político que reage conforme variáveis outras que não somente a norma, a razão, ou as recomendações que a teoria normativa lhe endereça. Friedman parece ter respondido a esse problema defendendo um redirecionamento de foco para a teoria normativa: não são os juízes que ela deve pretender influenciar, mas a "opinião pública". O juiz somente seria limitado por razões à medida que sentir a expectativa deliberativa que há sobre ele. A corte será legítima, nessas condições, se conseguir atender a tal expectativa. 
Para além dessa reatividade, a ciência política também mostra que as próprias funções das instituições são, em alguma medida, cambiantes, em especial na defesa dos direitos fundamentais. Da interação resultam acomodações contingentes e instáveis. Essas oscilações crônicas criam dificuldades para a teoria normativa acostumada a pensar em termos mais rígidos. Se a democracia constitucional é um arranjo procedimental determinado ex ante, como explicar tais oscilações?

Uma saída intuitiva, já aventada por Friedman, seria dizer que as instituições se movimentam conforme as ondas da opinião pública. À medida que se distanciam do socialmente aceitável, elas corroem sua legitimidade e perdem espaço no jogo da separação de poderes. Elas decairiam no seu índice de credibilidade e se encolheriam. Essa hipótese, eventualmente, explica, mas não justifica. Se o objetivo é pensar na legitimidade dessas oscilações, o que nos interessa não é uma descrição das causalidades, mas as razões que fundamentam a demanda de obediência às decisões oriundas desse processo. Ou seja, trata-se de uma pergunta normativa, não empírica.

Nesse sentido, reformulada em termos normativos, pergunta-se: é possível justificar essas flutuações? Desconfio que sim. Se concordarmos que as variáveis de legitimidade da democracia não se esgotam no procedimento, mas abrangem também os resultados, passa a ser aceitável que a substância subordine, em algumas circunstâncias, o procedimento, ou seja, que a instituição que tenha alcançado a resposta mais compatível com um critério substantivo de legitimidade tenha boas razões para prevalecer independentemente de seu pedigree (subvertendo a estrutura formal).

$\mathrm{Na}$ verdade, é preciso supor mais do que isso. Waldron, por exemplo, aceita a tese de que a democracia tenha requisitos substantivos para além dos procedimentais. O ponto dele é outro: como todos discordarão sobre tal substância, não se pode atribuir a nenhuma instituição o ônus da resposta correta. Tudo que está ao alcance de uma democracia genuína é adotar um procedimento justo, que dê igual importância a cada cidadão. A essa autoridade, que é fixa independentemente do que decida, cabe resolver o desacordo. Em síntese, Waldron clama pela pureza de duas dimensões diferentes que não se comunicam: a teoria da autoridade (quem deve decidir) e a teoria da justiça (o que deve decidir). Ou seja, o fato de que a democracia necessita 
atender requisitos substantivos não produz repercussões institucionais, não diz nada sobre quem deve ter mais ou menos poder.

Dworkin rompe essa pureza. Para ele, democracia é um "esquema procedimental incompleto", pois não pode especificar, infinitamente, novos procedimentos para avaliar se as pré-condições democráticas foram respeitadas. ${ }^{505}$ Deve estar sempre sujeita a um exame conseqüencialista, caso a caso. O conteúdo mais ou menos aceitável de decisões substantivas pode repercutir, por isso, no arranjo de poderes. Ao contrário, Waldron diria que, do ponto de vista da autoridade, a democracia é um "esquema procedimental completo".

A ocorrência de flutuações não vai de encontro ao pensamento de Dworkin. Podem ser legítimas desde que atendam às condições que ele considera corretas (no caso, o ideal de "igual consideração e respeito"). Rawls adota posição similar. Flutuações seriam compatíveis com o seu "princípio liberal de legitimidade", desde que reguladas pelo idioma da "razão pública". Essa leitura que proponho dos dois autores pode parecer ligeiramente excêntrica e diluir uma distinção analítica relevante entre autoridade legítima e decisão legítima ("quem decide" e "o que decide"), determinados, respectivamente, ex ante e ex post. De fato, não é bem a "flutuações" que Dworkin e Rawls se referem. Eles simplesmente aceitam um mecanismo nãomajoritário e não-representativo por concordarem que a democracia não pode prescindir de uma pretensão epistêmica sobre princípios, e deve dispor de processos que maximizem a probabilidade de boas decisões. Fornecem, ademais, um critério moral independente para julgá-las. Se isso é verdade, a decisão judicial não é legítima per se, mas desde que atenda a esse critério.

Portanto, é plausível inferir que, a não ser que eles adotassem uma presunção da infalibilidade judicial, o que não fazem, pois se limitam a um cálculo probabilístico, decisões legislativas serão mais legítimas que as judiciais se aquelas, e não estas, atenderem àquele critério moral (e vice-versa). Negam legitimidade $a$ priori, pelo mero pedigree majoritário, ao parlamento, mas não aceitam passivamente qualquer ativismo judicial. É exatamente isso que entendo como justificativa da flutuação. Não se trata de pura subordinação do procedimento à substância, ou de ${ }^{505}$ Freedom's Law, p. 32. 
negar dever de obediência a uma decisão judicial ou legislativa porque entendemos que elas violam um parâmetro moral. Os problemas de uma posição assim são bem conhecidos. Sustento, apenas, que é desejável que poderes desafiem uns aos outros (já que, como vimos no último capítulo, essa é sempre uma possibilidade em aberto ao longo do tempo) desde que articulem razões de melhor qualidade. Não dissolvo a autoridade: decisões continuam a ser obrigatórias, mesmo que discordemos. Mas sustento que a democracia tem a ganhar se um padrão como a razão pública estimular o desafio deliberativo entre poderes. Saber qual o melhor momento desse desafio é outra questão, que certamente vai exigir um cálculo prudencial e balanceado. Mas isso fica para outra parte deste capítulo.

Carreguei os últimos dois parágrafos com argumentos fortes sem as mediações suficientes. Deixe-me caminhar com mais calma. A interpretação de Rawls que esbocei acima constituirá o guia para o restante do capítulo. Descrevo-a melhor abaixo para, em seguida, voltar à reação de Waldron e analisar as suas limitações.

Rawls propõe-se a construir uma teoria da legitimidade para sociedades pluralistas. A pergunta de fundo de uma empreitada como essa costuma ser posta assim: que condições devo exigir para obedecer a uma decisão da qual discordo? Se discordamos, e continuaremos a discordar sempre, como viver em conjunto e tomar decisões coletivas que vinculem a todos? Dizer que devemos estruturar um procedimento democrático, por si só, não resolve com precisão: o que deve estar embutido nesse procedimento?

O Liberalismo Politico é uma tentativa de encontrar essa resposta. Nesse livro, Rawls parte de uma distinção fundamental entre "doutrina filosófica abrangente" e "concepção política de justiça". A primeira apresenta um projeto completo sobre a "boa vida", uma concepção ética integral. A segunda busca construir um ponto de apoio capaz de acomodar uma característica inerente às sociedades democráticas: a co-existência de doutrinas abrangentes incompatíveis, porém razoáveis, ou, numa expressão, o "fato do pluralismo razoável" ${ }^{506}$ A cultura democrática está condenada a conviver com tal diversidade. Como almejar uma sociedade justa e estável, de

\footnotetext{
${ }^{506}$ Cf. Political Liberalism, p. xvi.
} 
indivíduos livres e iguais, se seus cidadãos adotam doutrinas abrangentes inconciliáveis? Como justificar o uso da coerção?

O único caminho é encontrar uma base pública de justificação das ações políticas que seja aceitável em meio ao pluralismo. Essa sociedade, para Rawls, precisa ser estável pelas razões corretas, e não somente promotora de um modus vivendi decorrente de um acordo instrumental de conveniência. Cidadãos precisam compartilhar de sua estrutura básica. ${ }^{507}$

A dificuldade que se impõe a esse projeto, nesse sentido, é a elaboração de uma concepção autônoma de justiça, que se sustente nas próprias pernas, e não seja mera derivação de uma doutrina abrangente. Que seja, portanto, política somente. Rawls atende tal meta por meio do princípio liberal de legitimidade. Esse princípio estabelece a reciprocidade como critério para o uso válido de poder: a coerção é apropriada somente quando acreditamos que as razões que oferecemos podem razoavelmente ser aceitas por outro cidadão qualquer, independentemente de suas convicções abrangentes. É o que o autor chama de "razão pública". Se, quando discutimos escolhas políticas fundamentais, não argumentamos a partir dessa categoria especial de razão, mas com base numa doutrina abrangente, violamos o nosso "dever de civilidade" (por meio do qual construímos laços de "amizade cívica"). ${ }^{508}$

A razão pública, portanto, impõe um limite: podemos conceber vários tipos de razões para justificar decisões coletivas, mas somente será legítima aquela que não dependa de uma doutrina abrangente. $\mathrm{O}$ argumento é ainda mais específico: o limite da razão pública não se aplica, necessariamente, apesar de desejável, a toda e qualquer questão, mas, no mínimo, aos elementos constitucionais essenciais e às questões de justiça básica. ${ }^{509}$ Quando esses assuntos estão em jogo, e o debate se passa num fórum público, a razão pública fornece uma moldura necessária para disciplinar a

\footnotetext{
$\overline{{ }^{507} \text { Ibid, p. xxxviii ou } 218 \text {. }}$

${ }^{508}$ Ibid, p. xxxviii ou 253.

${ }^{509}$ Sobre as distinções entre "constitutional essentials" e "questions of basic justice", cf. Political Liberalism, p. 228-229. Frank Michelman explica em maior detalhe por que, para Rawls, a revisão judicial deve se limitar, todavia, aos "constitutional essentials" ("Justice as Fairness, Legitimacy and the Question of Judicial Review”).
} 
comunicação. ${ }^{510}$ Não se deve ir além dela e tentar impor a "verdade completa" (uma vez que, sobre essa, não há acordo possível). ${ }^{511}$

Se uma constituição contemplar os elementos essenciais do liberalismo político e, adicionalmente, conseguir despertar uma cultura da razão pública, as relações políticas atingem o padrão democrático, e não se fundam mais na pura força $^{512}$ Ações políticas serão legítimas somente na medida em que possam ser traduzidas por tal linguagem, e por isso o estímulo à deliberação pública é uma tarefa central das instituições. Grosso modo, é assim que Rawls responde àquela pergunta inicial. A razão pública é um padrão de argumentação moral que deve disciplinar a deliberação política, mas que não se confunde com ela, e, portanto, subsiste enquanto critério autônomo para julgar a legitimidade das decisões. ${ }^{513}$

É importante registrar como ele insere o papel da Suprema Corte nesse arranjo. Para o autor, trata-se de uma instituição exemplar da razão pública, que cumpre papéis institucionais relevantes para a concretização de princípios do constitucionalismo. ${ }^{514}$ À corte, mais precisamente, incumbe três tarefas. Em primeiro lugar, utilizar-se da razão pública para evitar que maiorias transitórias rompam a estrutura da constituição. ${ }^{515}$ Pode, contudo, desempenhar funções para além desse papel defensivo convencional. Por ser a única instituição que decide exclusiva e obrigatoriamente com base nesse tipo de razão, ela lhe confere efeito contínuo, e, por conseguinte, cumpre um papel educativo. Se a razão pública é uma linguagem

\footnotetext{
${ }^{510}$ Ibid, p. 214.

${ }^{511}$ Rawls refina um pouco mais essa idéia por meio das concepções inclusiva e excludente de razão pública (Ibid, p. 247).

${ }^{512}$ Há dois tipos de "elementos constitucionais essenciais": os princípios gerais que estruturam o processo político; e os direitos e liberdades a serem respeitados por maiorias (Ibid, p. 227).

${ }^{513}$ É essa distinção entre a deliberação política e o critério moral para julgá-la que algumas teorias da democracia deliberativa deixam de fazer, como se o exercício deliberativo constituísse um valor por si mesmo, ou como se garantisse a boa decisão pelo simples fato de realizar um processo deliberativo. Agradeço a Álvaro de Vita por esse esclarecimento.

${ }^{514}$ Ibid, p. 231.

515 "By applying public reason the court is to prevent that law from being eroded by the legislation of transient majorities (...)" (Ibid, p. 233). É interessante observar uma passagem em que Rawls se mostra ciente das limitações da corte no longo prazo: "Now admittedly, in the long run a strong majority of the electorate can eventually make the constitution conform to its political will. This is simply a fact about political power as such. There is no way around this fact, not even by entrenchment clauses that try to fix permanently the basic democratic guarantees. No institutional procedure exists that cannot be abused or distorted (...)" (Ibid, p. 233). Em outra, ainda, mostra como a corte está constrangida pelo "povo agindo constitucionalmente": "The constitution is not what the Court says it is. Rather, it is what the people acting constitutionally through the other branches eventually allow the Court to say it is. A particular understanding of the constitution may be mandated to the Court by amendments, or by a wide and continuing political majority (...)" (Ibid, p. 237).
} 
necessária da democracia, ao menos para seus elementos essenciais, a corte contribui enormemente ao não deixar que esse código moral saia da agenda. Confere-lhe "vivacidade e vitalidade". 516 Cidadãos se beneficiam da prática da corte ao aprenderem um modo particular de discutir os elementos essenciais da constituição. ${ }^{517}$

Waldron, naturalmente, vê problemas sérios nesse modelo de defesa da revisão judicial. Não entende como Rawls, ao admitir a existência de diversas doutrinas abrangentes incompatíveis, porém razoáveis, não leva a sério a possibilidade de que, no nível da justiça política, o mesmo grau de desacordo possa também emergir. A razão pública, segundo Rawls, seria potente o suficiente para dissolver desacordos sobre questões essenciais de justiça, exceto em pequenos detalhes. ${ }^{518}$ Para Waldron, porém, como já analisei na dissertação, nas “circunstâncias da política", há desacordo de cima abaixo, e a razão pública não ameniza esse problema. O pluralismo em relação a doutrinas abrangentes não seria o único tipo de pluralismo existente nas sociedades democráticas. Nelas, há também pluralismo sobre justiça. ${ }^{519}$ Rawls seria, assim, incoerente. ${ }^{520}$

A solução de Rawls para o desenho institucional é também objeto de ataque de Waldron por razões similares. Rawls, como se sabe, mesmo que reconheça a "justiça procedimental imperfeita", não abre mão de um juízo probabilístico para a construção de instituições: elas serão mais legítimas quanto maior a probabilidade de que suas decisões sejam corretas. Cabe às constituições, por isso, maximizar as chances do acerto. ${ }^{521}$ A justiça constrange o procedimento, e instituições devem ser desenhadas

\footnotetext{
${ }^{516}$ Ibid, p. 236-237.

${ }^{517}$ É importante mencionar que Rawls não faz propriamente uma "defesa positiva" de um modelo de revisão judicial, como se outros arranjos fossem inferiores a este. Afirma apenas que a Suprema Corte é um exemplo de como a razão pública pode funcionar dentro das instituições. É curioso, apesar dessa ressalva, como ele propõe que, quando estivermos em dúvida se estamos de fato usando "razão pública", que imaginemos uma corte decidindo. (Ibid, p. 254)

${ }^{518}$ Ibid, p. 226.

${ }^{519}$ Law and Disagreement, p. 158.

520 "This leaves us with the rather uncongenial conclusion that there is no such thing as reasonable disagreement in politics. (...) In the world we know, people definitely disagree - and disagree radically - about justice. Moreover, their disagreement is not just about details but about fundamentals". (cf. Law and Disagreement, p. 152-153)

521 "The second problem, then, is to select from among the procedural arrangements that are both just and feasible those which are most likely to lead to a just and effective legal order". (Theory of Justice, p. 198) "The fundamental criterion for judging any procedure is the justice of its likely results. (...) Everything depends on the probable justice of the outcome. (...) I mention these familiar points about majority rule only to emphasize that the test of constitutional arrangements is always the overall balance of justice" (Ibid, p. 230-231).
} 
com um olho nos resultados substantivos que elas tendem a gerar. Nesse sentido, como observa Waldron, Rawls requer que o desacordo sobre justiça esteja resolvido antes que se construam instituições. E Waldron reage: “Como, porém, podem os cidadãos concordarem em questões de escolha constitucional se eles discordam sobre o telos de tal escolha?" 522 Segundo ele, para a manutenção de uma política pacífica apesar do desacordo razoável sobre a substância, somente resta esperar que pessoas concordem com algum procedimento decisório. E não podemos alcançar esse acordo se pensamos sobre procedimento "à sombra de nossas convicções substantivas", como faria Rawls. ${ }^{523}$ Essa solução conhecida de Waldron é o que chamei acima de “esquema procedimental completo". Acusá-la de subordinar justiça ao procedimento seria, para ele, uma petição de princípio, já que não há um "porto seguro substantivo", imune ao desacordo, a partir do qual se possa julgar o resultado de ritos decisórios. Seria necessário haver limites ao "espaço lógico" que nossas visões substantivas ocupam. ${ }^{524}$

Waldron, porém, ao levar o desacordo às últimas conseqüências, cai na sua própria armadilha. ${ }^{525} \mathrm{Se}$ discordamos tanto assim, por que então compartilharíamos do procedimento sugerido por ele? Se há desacordo tão profundo, por que devemos preferir a solução dele, e não a de outros? Ele talvez dissesse que a vantagem de sua solução é recorrer a um procedimento sem expectativas de resultado, mas que apenas respeita a igual voz de cada um. Mas o que fazer se não houver acordo quando a isso? Não são poucos os que suspeitam que a regra de maioria representativa não necessariamente confere a cada um "igual voz".

Muitos autores já apontaram para essa inconsistência na estrutura argumentativa de Waldron. Estlund, numa das críticas mais elaboradas, demonstra

\footnotetext{
${ }_{522}^{523}$ Law and Disagreement, p. 157.

${ }_{523}$ "To imagine that deliberative politics (or any form of peaceful politics) is possible is to imagine that people can agree on some of these procedural points even though they disagree on the merits of the issues that the procedures are, so to speak, designed to house. It is to imagine, in other words, that the procedural issues and the substantive issues are in some sense separable". (Ibid, p. 160)

${ }_{524}^{524}$ Ibid, p. 160.

${ }^{525}$ Como disse Wil Waluchow: "In Jeremy's case, everything in politics is subject to reasonable disagreement, and nothing, as a result, can be established which meets the no-reasonable-disagreement criterion, the standard which Waldron has set for himself and others, and which cannot possibly be met. In short, Jeremy's theory falls victim to his own standard of acceptable argument and institutional design". ("Constitutions as Living Trees", p. 49) "As a result, Waldron has given us no convincing reason to prefer his solution to the circumstances of politics over those offered by Advocates like Rawls, Dworkin and Freeman". (Ibid, p. 45)
} 
que, se Waldron adota uma concepção liberal de legitimidade política (ou seja, que a autoridade seja justificável a cada indivíduo que lhe deve obediência), não há como partir de uma premissa de "desacordo profundo" (deep disagreement), sob pena de cair na armadilha do anarquismo filosófico, segundo o qual não existe autoridade política legítima. Em outras palavras, se existe a possibilidade de justificar a autoridade com base num princípio liberal, não se pode sustentar que todo e qualquer desacordo sobre a base de legitimidade é razoável. ${ }^{526}$ Não há como escapar do ônus de traçar a linha entre razoável e irrazoável em algum ponto do raciocínio (e o próprio Waldron o faz por meio de um modo de argumentação moral semelhante à razão pública de Rawls). Um regime legítimo, se precisa ser justificável para todos, tem que contar com algum acordo mínimo compartilhado.

O que disse até agora não é suficiente para esgotar os desdobramentos do debate, o que exigiria tempo e espaço desproporcionais ao propósito da tese nesse ponto. Basta-me, aqui, sinalizar o caminho para resgatar os argumentos de Rawls (e também de Dworkin) em face do ataque de Waldron, e firmarmos a adesão à razão pública como critério substantivo adequado para a justificação das oscilações inerentes à separação de poderes.

Voltando ao ponto de partida: se a separação de poderes estimula um jogo político que produz funções cambiantes, o que podemos almejar? É plausível esperar que tais acomodações sejam influenciadas por uma cultura da deliberação, e não por pura distribuição de forças?

A corte cumpre um papel importante no esforço institucional para fazer com que o bom argumento seja variável de peso na competição democrática. Um retorno à tensão entre forma e substância ajuda a clarear este ponto. Waldron tenta suprimir essa tensão na montagem de instituições. Para ele, quando discutimos a autoridade democrática, é sobre procedimentos, e nada mais, que devemos falar. Como resultado dessa orientação normativa, temos um regime de supremacia parlamentar (por ser o

\footnotetext{
${ }^{526}(\ldots)$ "that if reasonable disagreement is as deep as he says it is, then there is no political arrangement that is either obligatory for all citizens, or even permissibly implemented and enforced" (Cf. Estlund, "Jeremy Waldron on Law and Disagreement", p. 118) "If, as it appears, Waldron accepts the No Reasonable Objection view of legitimacy, then consistency requires that he reject either Deep Disagreement or any positive account of legitimacy such as Fair Proceduralism" (Ibid, p. 114).
} 
procedimento mais justificável). Mesmo que possamos discutir a justiça das decisões legislativas, essa autoridade não pode ser questionada com base em argumentos substantivos. Afinal, discordamos e precisamos de um foro comum para resolver nossas diferenças.

Outra saída seria suprimir a tensão, mas para o outro lado. Assim, se a democracia precisa de decisões acertadas sobre questões de princípio, condição de sua própria sobrevivência, atribuímos ao controle de constitucionalidade essa missão. $\mathrm{O}$ problema, contudo, é que essa resposta comete um outro pecado: presume que a corte é infalível.

A terceira saída, mesmo consciente da falibilidade das instituições, insiste numa alternativa probabilística. Precisaríamos de instituições que ao menos tenham maior probabilidade de alcançar a resposta correta em questões de justiça. É a proposta de Rawls, como vimos. Minha resposta se aproxima a essa, com algumas qualificações.

Se forma e substância são, ambos, componentes necessários da legitimidade, o arranjo institucional se revigora quando incorpora essa tensão. Num contexto de supremacia parlamentar pura, nos moldes de Westminster, as demandas de substância não desaparecem, obviamente. No entanto, ao domesticar a tensão no plano da escolha institucional, e optar pela justificativa da autoridade somente com base no pedigree do parlamento, obscurece-se uma dimensão que continua presente na política, mas enfraquecida. O potencial crítico e deliberativo da separação de poderes é anestesiado por meio de uma mensagem de que o parlamento é o topo da escala hierárquica e de que não pode ser desafiado. Dificulta que críticas substantivas às decisões legislativas tenham expressão institucional, exceto na própria via parlamentar. O teste de legitimidade torna-se difuso e extra-institucional. A resistência contra decisões que mais claramente violam a razão pública tem menores alternativas para canalizar sua voz. O controle de constitucionalidade, por outro lado, gera a sensação de limite externo, e de fato opera um contrapeso inserido no próprio coração do arranjo de forças. É o que arriscamos perder sem a revisão judicial (considerando que a corte desempenhe essa tarefa satisfatoriamente). 
E o que se ganha com ela? A sugestão de Rawls se adapta bem: a corte pode dar maior vitalidade à razão pública, formentar um tipo de argumentação moral da qual a democracia não pode abrir mão. Sem ela, direitos correriam o risco de serem diluídos como uma razão entre outras, sem nenhuma dignidade especial. Claro que uma cultura política vigorosa pode, eventualmente, levar direitos a sério no calor do debate parlamentar. Quando planejamos instituições, entretanto, estamos no terreno das probabilidades, de exercícios de tentativa e erro. Não parece ser insensata a adoção de uma corte que recebe como principal missão a proteção de direitos, e está autorizada a ser, predominantemente, monoglota: será ignorada se não fundamentar suas decisões com base na linguagem dos princípios. Essa opção não se impõe por força da lógica, mas, na expressão de Michelman, como um ato de "prudência liberal", uma estratégia para institucionalizar determinada moralidade política de modo mais eficaz. ${ }^{527}$

No modelo de Westminster, não se discute quem deve decidir. No modelo de revisão judicial, o debate sobre as restrições ao parlamento é mantido na agenda política cotidiana. O parlamento ganha um ônus adicional para demonstrar que respeitou as pré-condições da democracia. A existência de revisão judicial estimula essa tensão virtuosa entre forma e substância. Não preciso supor que o legislador esteja mais inclinado ao erro e a corte mais próxima do acerto, nem mesmo que a legitimidade do legislador esteja exclusivamente apegada à forma e da corte à substância (apesar de ambas afinidades serem plausíveis), para defender a contribuição dessa circularidade permanente. ${ }^{528}$

Há mais uma ressalva importante. Não estamos diante de uma encruzilhada binária entre corte e parlamento. A perspectiva do diálogo, ao relativizar a última palavra, mostra que a alternativa à supremacia do parlamento não é necessariamente a soberania, pura e simples, da corte, mas um jogo interativo mais rico e complexo. A

\footnotetext{
$\overline{{ }^{527} \text { Visão que também já estava incipiente em minha dissertação de mestrado, onde concebi a revisão }}$ judicial como promotora de uma "multiplicação dos testes", como "veto qualificado pela linguagem dos direitos", um "estratégia de prudência nos momentos intermediários do processo decisório coletivo" (cf. Controle de Constitucionalidade e Democracia, pp. 132 e 133).

${ }^{528}$ Mesmo que se possa dizer que também há tensão deliberativa e "circularidade" dentro do próprio parlamento, e também entre diferentes legislaturas ao longo do tempo, destaco aqui a virtude dessa particular tensão inter-institucional, não apenas da intra-institucional.
} 
inexistência de revisão judicial, por outro lado, estimula uma cultura da soberania do parlamento.

A democracia não pode abdicar do julgamento conseqüencialista para certificar a legitimidade de instituições. Esta não deve se limitar a um critério formal ex ante e não se esgota num cálculo de engenharia institucional, com régua e compasso. A solução de Bentham para o conflito entre direito e moral é ilustrativa: "Obedeça pontualmente, censure livremente". ${ }^{529}$ Ele também permitia, entretanto, a válvula de escape da resistência para o caso de decisões políticas excessivamente injustas. A possibilidade de resistência e censura institucionalizadas é o que estamos discutindo. Mas suspeito, como Rawls, que a função da revisão judicial também vá além disso. Não é apenas defensiva, conforme veremos no restante do capítulo.

\section{Legitimidade contextual e comparativa: desempenho deliberativo}

Retomemos o fio da meada. Vimos acima que a democracia, ou o autogoverno coletivo, não é uma prática que possa ser traduzida monoliticamente numa instituição, sem contar o que ela faça. Indiquei também como a interação entre corte e parlamento gera uma tensão virtuosa e permanente. Possibilita-se que o teste de legitimidade substantiva não seja simples censura social difusa, mas um mecanismo endógeno de controle. Toda essa parafernália está sujeita a falhar, certamente, mas não se pode dizer que o esforço institucional não seja válido por isso. Este esforço torna a deliberação constitucional, aquela conduzida nos termos da razão pública, mais provável de ocorrer. Para tanto, como os poderes devem se portar? E quem deve ter a última palavra provisória?

Por mais necessário que seja definir o detentor da última palavra provisória, a partir de um outro olhar, este é um mero detalhe. Saber quem deve prevalacer é uma questão contingente. Não há resposta de princípio, geral e abstrata. O valor de um processo contínuo de formação da vontade política precisa ser percebido, e não deve ser ofuscado por aquela discussão. A corte, caso detenha esse poder, não é um garante de decisões corretas e não pode ser percebida como tal. É um mecanismo que tenta

\footnotetext{
529 "Obey punctually, censor freely" (citado por Hart em "Positivism and the Separation of Law and Morals").
} 
evitar o esfriamento e a marginalização da linguagem dos direitos, a indiferença e a omissão de certas razões tidas como fundamentais na legitimação da política. Ela busca alimentar uma cultura pública de maior densidade deliberativa. Será legítima à medida que cumprir essa função. Claro que há riscos. Para ficar nos principais deles: do lado judicial, o legalismo hermético, o imperialismo retórico, a soberba do guardião entrincheirado e monopolista; do outro lado, a deferência ou o comodismo legislativo. Proponho que uma alternativa para redução desses riscos seja desenvolver uma demanda mais forte de diálogo que, se impregnada na prática decisória dos poderes, traz um ganho exponencial ao desenho. Nesse modelo ideal, não há nem um guardião entrincheirado, nem um legislador acanhado e deferente, mas dois poderes engajados no exercício da persuasão. Divergem, mas com respeito mútuo, sem presunção.

Neste tópico, suscito o ângulo competitivo da interação, e o "desempenho deliberativo" é a sua medida genérica. ${ }^{530}$ A interação entre instituições que buscam maximizar seus respectivos desempenhos deliberativos é o que de melhor podemos esperar de uma democracia organizada sob o princípio da separação de poderes. Estimula uma competição pelo melhor argumento e traz vibração ao regime. Implanta uma pressão por consistência. Fundamentalmente, insere a tensão entre forma e substância no centro desse arranjo.

Torna-se possível, assim, pensar na legitimidade de cortes e parlamentos de maneira contextual e comparativa. Legitimidade política é um predicado institucional volátil, que dependerá, em parte, dos resultados, e não somente das credenciais prévias. É uma meta a ser conquistada e conservada, a cada decisão. O desempenho deliberativo pode ser o princípio regulador das oscilações entre corte e parlamento. Esboçar uma escala de critérios qualitativos que permitam mensurá-lo é, nesse sentido, uma tarefa fundamental da teoria democrática.

\footnotetext{
${ }^{530}$ É necessário aprofundar o conceito de desempenho deliberativo de cortes e parlamentos, mas essa tarefa não caberia nesta tese. Este conceito combina elementos procedimentais que facilitam a boa deliberação, com parâmetros argumentativos que ambas instituições devem cumprir (de acordo com suas respectivas diferenças). Para os fins desse trabalho, entenda-se "desempenho deliberativo" como a medida do grau de aproximação de um ideal deliberativo.
} 
Cortes e parlamentos têm responsabilidades deliberativas, e podem desafiar-se mutuamente a exercê-las. Isso não é feito sem conflito, incerteza ou risco de erro. Suponho que elas possam ser consideradas mais ou menos legítimas a depender de seu respectivo desempenho. Por ser este um critério conseqüencialista de legitimidade, traz complexidade à separação de poderes.

Alocar, previamente, a "última palavra provisória", é uma escolha indispensável, e não pode contar com mais do que uma expectativa probabilística do acerto, como vimos. O eventual "erro" daquele poder que a detém, ademais, não faz essa decisão perder autoridade. Torna, contudo, mais legítimo o desafio do outro poder. Esse é o preço que instituições pagam quando não tomam decisões com justificativas razoáveis e transparentes.

Empiricamente, a exata delimitação do poder da revisão judicial não se define a priori, mas na interação. Ou seja, depende tanto de suas decisões quanto das do parlamento. Quer dizer que não há arranjo formal pré-fixado? Se essa pergunta se refere aos detalhes das atribuições de cada um, sim. O que está pré-fixado é a lógica flexível da separação de poderes, não as suas minúcias, que variarão no decorrer do tempo. A qualidade deliberativa desse jogo pode fundamentar a legitimidade dessas mutações, desde que a razão pública seja o idioma da instituição cuja decisão prevalece.

Até aqui, sustentei basicamente que a instituição com o melhor desempenho deliberativo sobressai-se na competição pelo melhor argumento e tem legitimidade para desafiar a outra. No entanto, essa proposição parece simplista e causa inúmeros problemas práticos. O mais óbvio deles é: e se as duas utilizarem da razão pública, fizerem um claro esforço de maximização de seu desempenho e, ainda assim, discordarem?

Uma resposta seria: prevalece, no final das contas, aquela que tiver a prerrogativa da última palavra provisória. Num sistema de controle de constitucionalidade, a corte, portanto. Todavia, se, em outra perspectiva temporal, há circularidade, e se a instituição derrotada - o parlamento - poderá sempre reiniciar uma nova rodada, não caberia à corte deferir? No extremo do desacordo sincero, 
engendrado pela razão pública, seria possível sustentar que a instituição com o melhor pedigree deve ter um trunfo especial? ${ }^{531}$

Essa aparenta ser uma questão fundamental de qualquer teoria do diálogo. Se a última palavra provisória não impede novas rodadas procedimentais, significa que a estabilização de um determinado tema coletivo ocorreria somente a partir de alguma acomodação entre os dois poderes, ou quando um deles aceitar a posição do outro (a qual, a propósito, pode ser resultado de seguidas negociações argumentativas de rodadas anteriores). A abdicação judicial na situação-limite talvez fosse uma defesa normativa plausível. A corte daria ao parlamento o benefício da dúvida. No entanto, este cenário é mais especulativo do que realista. Com maior freqüência, poderes reduzem progressivamente o desacordo, fazendo concessões recíprocas. É um jogo político, mas nada impede que uma deliberação genuína influencie o processo.

Neste tópico, analisei, sobretudo, as instituições em disputa, e concebi uma medida genérica para avaliar essas redefinições de espaço. Tratei, portanto, do desempenho deliberativo na perspectiva intra-institucional, o qual contribui para a legitimidade de cada instituição, considerada separadamente. Mas podemos também olhar para o desempenho inter-institucional, ou seja, para o que essas instituições produzem em conjunto. Vejamos isso nos dois próximos tópicos.

\section{Modulação das virtudes ativas e passivas}

No capítulo anterior, mostrei que um certo tipo de diálogo é inevitável ao longo do tempo, ainda que numa acepção frágil desse termo. Nesse capítulo, comecei a conceber um diálogo mais genuíno e consciente. Defendi que o desempenho deliberativo é uma medida promissora para avaliar a legitimidade em cada contexto. Nesse tópico, quero examinar como a corte, especificamente, pode participar desse processo, para além da orientação genérica do tópico anterior, segundo o qual um poder terá legitimidade para desafiar o outro quando sobressair-se no seu desempenho deliberativo.

\footnotetext{
${ }^{531}$ Argumento que ecoa Waldron: sem base para o acordo substantivo, resta tentar um procedimental.
} 
O grau de intervenção da corte no diálogo está sujeito a maior desconfiança. Afinal, ela tem um pedigree menos auto-evidente no senso comum sobre a democracia, como vimos no capítulo 3 (mesmo que levados em conta os senões do capítulo 2). Há também uma preocupação do ponto de vista do estado de direito: é necessário haver divisão clara de funções, alguém que produza regras gerais e outro que as aplique, de maneira estável e previsível.

A narrativa até agora não se ateve a qualquer especificação de papéis. Isso se deve, para insistir num ponto anterior, ao fato de que essa divisão de funções é difícil de ser estabelecida no campo dos direitos fundamentais. Dizer que à corte cabe o papel negativo de declarar a inconstitucionalidade e ao legislador o propositivo passa longe de como o fenômeno efetivamente ocorre. Recorrer às velhas distinções entre criação e interpretação do direito seria insistir numa falácia. Não estou supondo que, em relação a direitos, cortes e parlamentos são institucionalmente equivalentes. ${ }^{532}$ Parece plausível constatar que ambos enxergam problemas por prismas bastante diversos, não redundantes. No entanto, quando parlamentos se engajam em argumentos de princípio, a divisão torna-se nebulosa e exige uma auto-compreensão mais refinada de cada poder sobre seu papel. A melhor capacidade institucional de um ou de outro, nesse caso, deixa de ser tão óbvia. Uma cartilha hermenêutica não resolve.

Uma forma de responder a essa dúvida é formular uma receita rígida. Ely nos oferece um exemplo disso. Suspeito, contudo, que tal alternativa não se adapta bem às oscilações inerentes à separação de poderes, ou que, no mínimo, diminui seu potencial. Shapiro propõe uma solução de meio-termo através da seguinte fórmula: "mais do que processo, menos do que substância". Defende um papel judicial predominantemente reativo que faça o legislador revisar eventuais contradições derivadas de seus atos. À corte não cabe agir imperialmente, mas servir de suplemento à competição. ${ }^{533}$

\footnotetext{
${ }^{532}$ Como na crítica de Whittington a Waldron.

${ }^{533}$ Ian Shapiro: "But they should generally operate in a reactive, 'safety valve', manner - holding legislators' feet to the fire rather than substituting for them. (...) [The court] should declare the domination that has emerged from the democratic process unacceptable, insisting that the parties try anew to find an accommodation. In this sense courts should never act imperially to impose results on recalcitrants legislatures or to protect society from majority rule. Rather, they should use their authority to get legislatures to confront contradictions in their own actions, forcing them to rethink way of working their majoritarian wills that do not countenance domination" (cf. The State of Democratic
} 
A posição que suscito neste tópico guarda alguma similaridade com essa tentativa intermediária de Shapiro, desde que se a entenda como recomendação maleável à corte, não como solução fechada. Proponho que a corte possa modular intervenção e contenção a depender do desempenho do parlamento. Nesse sentido, ela pode, às vezes, ir além do mero "suplemento à competição". Ela faz um juízo de ocasião, e opta por atos mais expansivos ou comprimidos. Para resgatar o vocabulário do capítulo 4, varia entre minimalismo e maximalismo. Volto, portanto, a uma questão que levantei no segundo tópico acima: a análise prudencial do contexto, uma ponderação caso a caso, tema por tema.

A idéia de "contexto", dependendo das variáveis que entram nesse cálculo, é certamente perigosa. No entanto, a tentativa de imaginar possíveis cenários políticos, em paralelo ao melhor papel que caberia à corte em cada um, enriquece a discussão. Podemos nos restringir à variável do desempenho deliberativo, combinada a situações de ação e omissão legislativa e à verificação do momento em que a lei questionada foi promulgada. Acredito que haja, em cada um, claras nuances que tornam o eventual "ruído anti-democrático" de uma declaração de inconstitucionalidade mais ou menos plausível (admitindo que o ruído faça algum sentido) conforme a circunstância.

Pensemos em quatro contextos básicos. Muitas outras variações e graus poderiam se desdobrar desses quatro, mas estes bastam para os fins do meu argumento. No primeiro, há omissão do legislador no atendimento de deveres constitucionais (mais facilmente exemplificados em constituições dirigentes que requerem ampla atuação legislativa para tornar eficazes boa quantidade dos direitos). No segundo, há ativismo legislativo sem grande consistência deliberativa. No terceiro, o ativismo legislativo é acompanhado de alto desempenho deliberativo. No quarto, mudando um pouco a chave, a corte analisa a constitucionalidade de uma lei antiga, aprovada por gerações anteriores.

Sem entrar em considerações sobre o eventual grau de inconstitucionalidade da lei, esses contextos, por si sós, insinuam situações bastante diferentes para justificar ou criticar a intervenção judicial. Exceto no terceiro caso, não parece tão Theory, p. 66-67). 
difícil, à luz do que foi dito até agora, defender a intervenção da corte. Esta simplesmente chamaria o parlamento a exercer sua responsabilidade deliberativa. $\mathrm{O}$ terceiro caso é delicado, mas a recomendação de abdicação judicial, sem mais, é prematura.

A decisão da corte, portanto, transcende a um juízo binário de constitucionalidade, como Bickel já disse há quase meio século. Pode-se não apenas constatar isso empiricamente, mas defender essa postura do ponto de vista normativo. Nessa zona discricionária do juízo de ocasião, não resta outra alternativa à teoria normativa senão uma receita pragmática e particularista. Saber quanto e quando decidir, encontrar um espaço do meio que evite o excesso e a timidez, é um desafio que a corte terá de resolver caso a caso. Do ponto de vista abstrato, não se pode dizer muito. Minha sugestão é que a corte module virtudes ativas e passivas por meio da prudência. Talvez esta seja uma fórmula ainda mais enigmática do que as recomendações de Bickel, pois este ao menos se posiciona mais claramente, salvo engano, pela auto-contenção como regra geral. Aproximo-me mais de Sunstein, que permite esse tipo de modulação casuística e fornece critérios para tanto.

O que deve nortear a corte nessa modulação? Qual propósito deve ela perseguir com ações de ativismo e contenção? Voltando ao parâmetro de legitimidade que firmei há pouco, a corte pode catalisar um debate mais qualificado sobre direitos nas esferas formais e informais da política. O que a protege é o bom argumento.

Ela não tem como impor sua decisão de cima para baixo, a não ser que o legislador a aceite passivamente. O interlocutor judicial pode provocar atritos e desafiar o legislador a enfrentar um tipo especial de razão que nem sempre pesa nas decisões parlamentares. À medida que o legislador se nega a fazê-lo de forma transparente, ele desperdiça a credencial eleitoral de que dispõe para inovar com responsabilidade na esfera política. Isso não implica a obrigação de demonstrar a resposta correta, ou de encontrar uma que alcance adesão consensual, mas de respeitar os ônus argumentativos de quem participa de um empreendimento deliberativo. A corte, nesse sentido, tem outras razões para enfrentar o parlamento que não as messiânicas. 
Novamente, o arquiteto institucional pode ficar irrequieto. A hipótese de desafio ou de discordância lhe remete a desobediência, o que romperia a coerência do estado de direito, geraria instabilidade ou mesmo o risco de anarquia. $\mathrm{O}$ conceito de diálogo inter-institucional pode realmente levar a mal-entendidos. Se sua orientação fosse "todos podem decidir tudo todo o tempo", os riscos de impasse, paralisia, colapso e vácuo de poder saltariam aos olhos. É por isso que a idéia de última palavra continua a desempenhar algum papel, apesar de termos amenizado sua importância, quer pela inevitabilidade da resposta ao longo do tempo, caso persista o desacordo, ${ }^{534}$ quer pela capacidade de a deliberação reduzir o dissenso, ou ao menos despertar respeito mútuo e a deferência. ${ }^{535}$

\section{Modelos de diálogo e seu potencial epistêmico}

Finalmente, consideremos a plausibilidade de uma promessa epistêmica embutida numa deliberação genuína. A expectativa é que a separação de poderes deliberativa tenha maior probabilidade de chegar à resposta certa. ${ }^{536}{ }_{-57}^{537}$ Ao contrário dos tópicos anteriores, não estou mirando o esforço de cada poder em maximizar o seu próprio desempenho deliberativo, e, assim, prevalecer sobre o outro. Tento perceber o produto dessa competição no agregado. Sob esse prisma, não mais se procura qual poder, entre corte e parlamento, está mais bem estruturado para alcançar a melhor resposta em questões de princípio. Olho para os dois como partes de um único desenho. Passo da deliberação intra-institucional para a inter-institucional.

\footnotetext{
${ }^{534}$ Justice Brandeis traduz essa idéia em frase eloqüente, indicando que o debate só termina (e portanto, a circularidade da separação de poderes), quando há um acordo: "no case is ever finally decided until it is rightly decided".

${ }^{535}$ Como, sinteticamente, diz Urbinati: "In fact, deliberation is not meant to impose a decision, but to achieve it" (cf. Representative Democracy, p. 198).

${ }^{536}$ Novamente, Urbinati exemplifica essa esperança trazida pela deliberação: "In any case, although a decision can be made without deliberation and although it can end in majority/minority divide, the assumption of deliberation is that a deliberated decision has more chance of being a good one and thus command rational conviction precisely because of the trial-and-error process it went through" (cf. Representative Democracy, p. 198).

${ }^{537}$ É também a esperança de Michael Perry: "In the constitutional dialogue between the Court and other agencies of government - a subtle, dialectical interplay between Court and polity - what emerges is a far more self-critical political morality than would otherwise appear, and therefore is likely a more mature political morality as well - a morality that is moving toward, even though it has never always and everywhere arrived at, right answers, rather than a stagnant or even regressive morality" (cf. The Constitution, the Courts and Human Rights, p. 113).
} 
Vimos, ao longo deste e do último capítulo, basicamente dois reguladores da interação entre os poderes. O primeiro diz respeito ao desenho procedimental, característica particular a cada constituição, ao qual não dedicamos atenção. $O$ segundo refere-se à atitude de cada poder em relação ao outro. Nessa dimensão, independentemente de quem tenha a última palavra provisória, ou de quem seja, do ponto de vista formal, o "guardião", diferentes modelos nascem a partir de distintas posturas.

Procuro, aqui, o modelo de interação que é mais sensível, ao longo do tempo, “à força de boas razões". ${ }^{538}$ Podemos pensar em dois tipos-ideais de interação, a partir da oposição entre duas atitudes puras: a deliberativa (que fala e escuta, com o objetivo da persuasão), e a adversarial (que fala para se impor). O primeiro está mais exposto publicamente ao argumento, mais aberto ao reconhecimento do diálogo, e mais disposto ao desafio deliberativo. ${ }^{539}$ Tentemos identificar por que este modelo de diálogo é mais tendente a se aproximar das melhores respostas.

John Stuart Mill talvez tenha elaborado o argumento mais conhecido a esse respeito. Refiro-me à fundamentação da liberdade de expressão e sua vinculação com a verdade. ${ }^{540}$ A sua distinção entre "verdade viva" e "dogma morto" é o atalho mais direto para entender o seu ponto. Para que a "verdade" tenha chance de emergir e continuar a exercer seu papel reflexivo, não se devem impor obstáculos à manifestação de opiniões de qualquer ordem. Só teremos segurança de que uma proposição é verdadeira na medida em que ataques a ela estejam abertos, e ela resista. ${ }^{541} \mathrm{Se}$, a título da conquista da verdade, se proíbe a contestação daí em diante, esta morre como um dogma que entorpece a capacidade crítica. Não se sustenta mais como verdade. Qualquer óbice à discussão corresponde a uma suposição de infalibilidade, e produz um efeito educativo perverso. ${ }^{542}$

\footnotetext{
${ }^{538}$ Nas palavras de Zurn: "to be responsive, over time, to the force of good reasons" (cf. Judicial Review and ..., p. 62).

${ }^{539}$ Está mais sujeito, portanto, à "força civilizadora da hipocrisia", na expressão de Elster (cf. Deliberative Democracy, pp. 12 e 111).

${ }^{540} \mathrm{O}$ capítulo 2 de On Liberty.

541 "There is the greatest difference between presuming an opinion to be true, because, with every opportunity for contesting it, it has not been refuted, and assuming its truth for the purpose of not permitting its refutation. Complete liberty of contradicting and disproving our opinion, is the very condition which justifies us in assuming its truth for purposes of action; and on no other terms can a being with human faculties have any rational assurance of being right" (cf. On Liberty, 24).

542 "All silencing of discussion is an assumption of infallibility" (cf. On Liberty, p. 22).
} 
Esse argumento de Mill não deixou de ser criticado. Por um lado, seria hiperprotetivo da liberdade de expressão, não permitindo restrições onde tais seriam justificáveis (como em casos de hate speech, por exemplo). Por outro, seria subprotetivo: a liberdade de expressão subordinar-se-ia a um fim externo. Não seria um fim em si mesmo, mas um meio para atingir a verdade. É assim que Martha Nussbaum o rejeitou. ${ }^{543}$

Não precisamos nos estender na interpretação de Mill para testar essas objeções. Ao adaptar o argumento para o plano institucional, a instrumentalização da liberdade de expressão em nome da verdade é exatamente o que se busca. Não é mais a dignidade individual que está em jogo. Trata-se de uma fundamentação para a desejabilidade da resposta, para a continuidade ininterrupta e franca do diálogo institucional. Sob pena de virarem "dogmas mortos", e, portanto, vulneráveis e desprotegidos, a proteção dos direitos deve inspirar rodadas deliberativas permanentes (ou ao menos a ausência de obstáculos a elas).

Ao tratar de um modelo de interação que se oriente por princípios deliberativos e que se preocupe em criar uma "cultura da justificação" para além de um puro jogo de forças, tento defender um tipo mais desejável de "reatividade política", onde o bom argumento cumpra algum papel. Se parlamentos e cortes adotam uma atitude deliberativa e levam em conta os argumentos expostos por cada um, desafiando-se reciprocamente quando consideram que têm uma melhor alternativa, é provável que produzam respostas mais criativas do que num modelo conflitivo e adversarial.

O recurso a Mill pode parecer artificial ou ingênuo, especialmente numa circunstância de "pluralismo razoável", predicado obrigatório de sociedades democráticas. "Verdade", ao menos no campo das relações políticas e sociais, é uma palavra que desperta suspeita. Mas o ponto de Mill é mais modesto. Ele não parece

\footnotetext{
543 "If one starts from the idea that each human being has dignity and deserves respect, and that politics must be grounded in respect for the dignity of all citizens as equals, one will find that Mill has put things just the wrong way round. Instead of thinking truth good because of what it does for the selfrespect and flourishing of individuals, he subordinates individual flourishing and dignity to truth" (cf. Hiding From Humanity, p. 327-328).
} 
supor uma verdade única, estável e a-histórica. Para ele, simplesmente, tampar ou suprimir o desacordo representa um perigo maior do que permitir o choque de idéias para que as melhores sobrevivam. O cético, mais uma vez, despejará uma infinidade de exemplos em que tal choque culminou em resultado inverso. Prefere ser realista ao seu modo, e propõe instituições que esfriem esse debate tendo em vista outros valores e serem preservados na boa ordem política. Isso não é, porém, incompatível com o que defendo neste tópico. É justamente nesse sentido mais cauteloso, e incorporado às próprias instituições, que o argumento de Mill conserva a sua força. Mantê-lo como ideal orienta a ação de cada poder, e não necessariamente subverte valores como a estabilidade e a segurança.

Outra reserva tradicional à deliberação refere-se à pressão temporal pela decisão. Tomar uma decisão imperfeita, em muitas circunstâncias, é seguramente preferível à paralisia na busca infinita da resposta correta. ${ }^{544}$ Podemos encontrar, inclusive, razões morais para justificar essa opção.

Deliberações parlamentares, judiciais e executivas não têm a mesma abertura, por exemplo, de um seminário acadêmico, mesmo que possam tratar, fundamentalmente, de um mesmo dilema. ${ }^{545}$ No entanto, a necessidade evidente de tomar decisões não exclui a responsabilidade coletiva de continuar a perseguir a melhor resposta. Posto dessa maneira, a democracia não é diferente de um "café filosófico" porque precisa tomar decisões, mas lhe é similar porque tem o ônus de buscar a melhor resposta (mesmo que com a necessidade permanente de tomar decisões provisórias e imperfeitas). Auto-aperfeiçoamento é um compromisso desse regime. Se decisões provisórias atendem à demanda de autoridade, o tempo não é um limite para a deliberação inter-institucional, mas um elemento central para maximizar a sua capacidade epistêmica.

\section{Conclusões}

\footnotetext{
${ }^{544}$ Nas palavras de Vermeule e Garrett: "The real question is not whether deliberation is beneficial, but how much deliberation is optimal" (cf. "Institutional Design of a Thayerian Congress", p. 1292).

${ }^{545}$ Como disse Elster: "Whereas scientists can wait for decades and science can wait for centuries, politicians are typically subject to strong time constraints" (cf. Deliberative Democracy, p. 9).
} 
Na separação de poderes, a interação é inevitável. A interação deliberativa é um ganho; a interação puramente adversarial, se não chega a ser uma perda, desperdiça seu potencial epistêmico.

Pode-se elevar a capacidade epistêmica da democracia, não eliminar a justiça procedimental imperfeita. Seria enganoso equiparar a falibilidade de todos os desenhos. Uma interação deliberativa não extingue a possibilidade do erro, mas maximiza as possibilidades do acerto.

A revisão judicial não precisa ser vista apenas como um dique ou uma barreira de contenção, mas também como um mecanismo propulsor de melhores deliberações. Não serve somente para (tentar) nos proteger da política quando esta sucumbe ao pânico ou irracionalidade, mas para desafiá-la a superar-se em qualidade.

A corte pode ser um catalisador deliberativo. Simboliza um esforço para fazer da democracia um regime que não apenas separe maiorias e minorias, estruture a competição política periódica e selecione as elites vencedoras e perdedoras, mas também seja capaz de discernir entre bons e maus argumentos. Isso não exclui a competição, mas a qualifica.

A dimensão deliberativa aponta para uma demanda mais densa de legitimidade, que não se limita a uma mera certificação procedimental. Torna a paisagem democrática mais variada. Não se limita a um retrato frio e insosso de uma coletividade tomando decisões, pura e simplesmente. Mostra os pressupostos e as condições subjacentes ao valor moral desse processo de decisão coletiva. 


\section{Bibliografia central ao argumento da tese}

ACKERMAN, Bruce. “The Storrs Lectures: Discovering the Constitution", Yale Law Journal, v. 93, 1984.

ARAÙJO, Cícero. Quod Omnes Tangit: Fundações da República e do Estado, tese de livre-docência apresentada ao Departamento de Ciência Política da FFLCH-USP no ano de 2004.

. "Representação, Retrato e Drama", Lua Nova, v. 67, 2006.

BICKEL, Alexander. "Foreword: The Passive Virtues", Harvard Law Review, v. 75, 1961.

. The Least Dangerous Branch: the Supreme Court at the bar of politics. Bobbs-Merrill, 1962.

. The Morality of Consent. Yale University Press, 1975.

. Supreme Court and the Idea of Progress, Yale University Press, 1970.

DAHL, Robert. Democracy and Its Critics, Yale University Press, 1991.

DWORKIN, Ronald. "Constitutionalism and Democracy", European Journal of Philosophy, v. 3, 1995.

. "Hart's Postcript and the Character of Political Philosophy", Oxford Journal of Legal Studies, v. 24, 2004.

."Equality, democracy and Constitution: we the people in court". Alberta Law Review, v. 28, n. 2, 1990. $\overline{86, \text { n. 3, } 1998 .}$

. "The Partnership Conception of Democracy", California Law Review, v.

ELY, John Hart. "Toward a Representation-Reinforcing Mode of Judicial Review”, Maryland Law Review, v. 37, 1977.

ESTLUND, David. "Jeremy Waldron on Law and Disagreement", Philosophical Studies, v. 99, 2000.

FRIEDMAN, Barry. "Dialogue and Judicial Review”, Michigan Law Review, v. 91, 1993.

. "The Politics of Judicial Review”, Texas Law Review, vol. 84, n. 2, 2005.

. "The Counter-Majoritarian Problem and the Pathology of Constitutional Scholarship", Northwestern University Law Review, v. 95, 2001. 
. “Taking Law Seriously", Perspectives on Politics, vol. 4, 2006.

2003.

. "Mediated Popular Constitutionalism", Michigan Law Review, v. 101,

. "The Importance of Being Positive: The Nature and Function of Judicial Review", 72 University of Cincinnati Law Review, v. 72, 2003.

FULLER, Lon. The Morality of Law, Yale University Press, 1969.

. "Reason and Fiat in Case-Law", Harvard Law Review, v. 59, 1945.

GARDBAUM, Stephen. "The New Commonwealth Model of Constitutionalism", American Journal of Comparative Law, v. 49.

KATYAL, Neal Kumar. "Justices as Advicegivers", Stanford Law Review, v. 50, 1997

LIMONGI, Fernando. “A Democracia no Brasil: Presidencialismo, coalizão partidária e processo decisório", Novos Estudos n. 76, 2006.

MENDES, Conrado Hübner. Controle de Constitucionalidade e Democracia. Campus Elsevier, 2008.

- Resenha de Jeffrey Goldsworhty (ed.), Interpreting Constitutions: a Comparative Study, em International Journal of Constitutional Law, v. 6, n. 2, 2008.

MILL, John Stuart. Considerations on Representative Government, em John Stuart Mill On Liberty and Other Essays, Oxford World Classics, 1998.

PICKERILL, J. Mitchell. Constitutional Deliberation in Congress: the Impact of Judicial Review in a Separated System. Duke University Press, 2004.

RAWLS, John. A Theory of Justice, Harvard University Press, 1971. . Political Liberalism, Columbia University Press, 2005.

SHAPIRO, Ian. The State of Democratic Theory, Princeton University Press, 2006.

SUNSTEIN, Cass. "Constitutional Agreements Without Constitutional Theories", Ratio Juris v. 13, n. 1, 2000.

1994.

. "Incompletely Theorized Agreements", Harvard Law Review, v. 108, . "Testing minimalism: a reply”, Michigan Law Review, v. 104, 2005.

. "The Supreme Court, 1995 Term - Foreword: Leaving Things Undecided", Harvard Law Review, v. 110, 1996. 
. One Case at a Time: Judicial Minimalism on the Supreme Court. Harvard University Press, 2001.

. The Partial Constitution. Harvard University Press, 1998.

STONE-SWEET, Alec, e MATHEWS, Jud. "Proportionality Balancing and Global Constitutionalism". Columbia Journal of Transnational Law, v. 47.1, 2008.

TULIS, Jeffrey. "Deliberation Between Institutions", em Peter Laslett e James Fishkin (eds.), Debating Deliberative Democracy, Blackwell, 2003.

WALDRON, Jeremy. "The core of the case against judicial review", Yale Law Journal, v. 115, 2006.

1994.

. "Freeman's Defense of Judicial Review", Law and Philosophy, v. 13, n. 1, . Law and Disagreement, Oxford University Press, 1999.

. The Dignity of Legislation,

WALUCHOW, Wil. "Constitutions as Living Trees: An Idiot Responds", Canadian Journal of Law and Jurisprudence, v. 18, 2005.

. A Common Law theory of Judicial Review: The Living Tree. Cambridge University Press, 2007.

WHITTINGTON, Keith. "Extrajudicial Constitutional Interpretation: Three Objections and Responses", North Carolina Law Review, v. 80, 2001.

2000.

. "Review Essay: In Defense of Legislatures", Political Theory, v. 28, n. 5,

\section{Referências mencionadas a título ilustrativo:}

BALL, Terence, FARR, James, HANSON, Russell (eds.). Political Innovation and Conceptual Change, Cambridge University Press, 1989.

BATEUP, Christine. "The Dialogic Promise: Assessing the Normative Potential of Theories of Constitutional Dialogue", Brooklyn Law Review, v. 71, 2006.

BORK, Robert. "Neutral Principles and Some First Amendments Problems", Indiana Law Journal, n. 47, 1971.

CALABRESI, Guido. "Foreword: Antidiscrimination and Constitutional Accountability [What the Bork-Brennan Debate Ignores]", Harvard Law Review, v. $105,1991$. 
DUNN, John. "Disambiguating Democracy", em "Colloquium in Legal, Political and Social Philosophy", New York University, 2007.

http://www.law.nyu.edu/clppt/program2007/readings/democracy.pdf

GALLIE, W.B. "Essentially Contested Concepts", em Philosophy and the Historical Understanding, Chatto\&Windus, 1964.

GAMBETTA, Diego. “'Claro!' An Essay on Discursive Machismo”, em Jon Elster (ed.), Deliberative Democracy, Cambridge University Press, 1998.

GARGARELLA, Roberto. "Full Representation, Deliberation and Impartiality", em Jon Elster (ed.), Deliberative Democracy, Cambridge University Press, 1998.

GOLDSWORTHY, Goldsworhty (ed.). Interpreting Constitutions: a Comparative Study, Oxford University Press, 2006.

GUNNELL, John. Between Philosophy and Politics: The Alienation of Political Theory, University of Massachusetts Press, 1986.

GUTMANN, Amy e THOMPSON, Dennis. Democracy and Disagreement, Harvard University Press, 1996;

HART, H.L.A. "American Jurisprudence Through English Eyes: The Nightmare and the Noble Dream", Georgia Law Review II, 1977.

HEISE, Michael. "Preliminary Thoughts on the Virtues of Passive Dialogue", Akron Law Review, v. 34, 2000.

KRONMAN, Anthony. "Alexander Bickel's Philosophy of Prudence", Yale Law Journal, v. 94, 1984-1985.

LAKOFF, George. Metaphors We Live By, University of Chicago Press, 1980.

LUNA, Erik. "Constitutional Roadmaps", Journal of Criminal Law \& Criminology, v. 90, 1999.

MACCORMICK, Neil. Institutions of Law, Oxford University Press, 2007.

MACINTYRE, Alasdair. "The Essential Contestability of Some Social Concepts", Ethics, v. 84, 1973.

MOELLER, John. "Alexander M. Bickel: Toward a Theory of Politics", The Journal of Politics, v. 47, 1985.

NUSSBAUM, Martha. Hiding From Humanity, Princeton University Press, 2006.

PALMER, Robert. "Notes on the Use of the Word 'Democracy': 1789-1799", Political Science Quarterly, v. 68, n. 2, 1953. 
PASQUINO, Pasquale, e FEREJOHN, John. "Deliberative Institutions", http://www.igs.berkeley.edu/research_programs/ppt/past/papers/deliberative_institutions.pdf., 1999.

PITKIN, Hanna. "Obligation and Consent-II", The American Political Science Review, v. 60, n. 1, 1966.

POCOCK, J.G.A. e BALL, Terence (eds.). Conceptual Change and the Constitution, University Press of Kansas, 1988.

PRZEWORSKI, Adam, ADAM, Michael E., CHEIBUB ALVAREZ, José Antonio e LIMONGI, Fernando. Democracy and Development: Political Institutions and Wellbeing in the World - 1950-1990, Cambridge University Press, 2000.

SCOTT, Joanne e STURM, Susan. "Courts as Catalysts: Rethinking the Judicial Role in New Governance”, Columbia Law School, Public Law and Legal Theory Working Paper 07-146.

SHAPIRO, Martin. “Apa: past, present and future”, Virginia Law Review, v. 72, n. 2, 1986.

TAYLOR, Matthew. "Judicial Independence", artigo apresentado ao seminário do Departamento de Ciência Política da USP no ano de 2007.

TUSHNET, Mark. "Policy Distortion and Democratic Debilitation: Comparative Illumination of the Counter-Majoritarian Difficulty", Michigan Law Review, v. 94, 1995.

VERMEULE, Adrian e GARRETT, Elizabeth. "Institutional Design of a Thayerian Congress", Duke Law Journal, v. 50.

WALDRON, Jeremy. Nonsense Upon Stilts, Methuen, 1987.

WHITTINGTON, Keith. "In Defense of Legislatures", Political Theory, v. 28, n. 5, 2000.

WOLIN, Sheldon. Politics and Vision........ . "Political Theory as a Vacation".

WOOTON, David, 'Liberty, Metaphor, and Mechanism: 'checks and balances' and the origins of modern constitutionalism", em $<$ http://www.constitution.org/lg/check bal.txt $>$ 